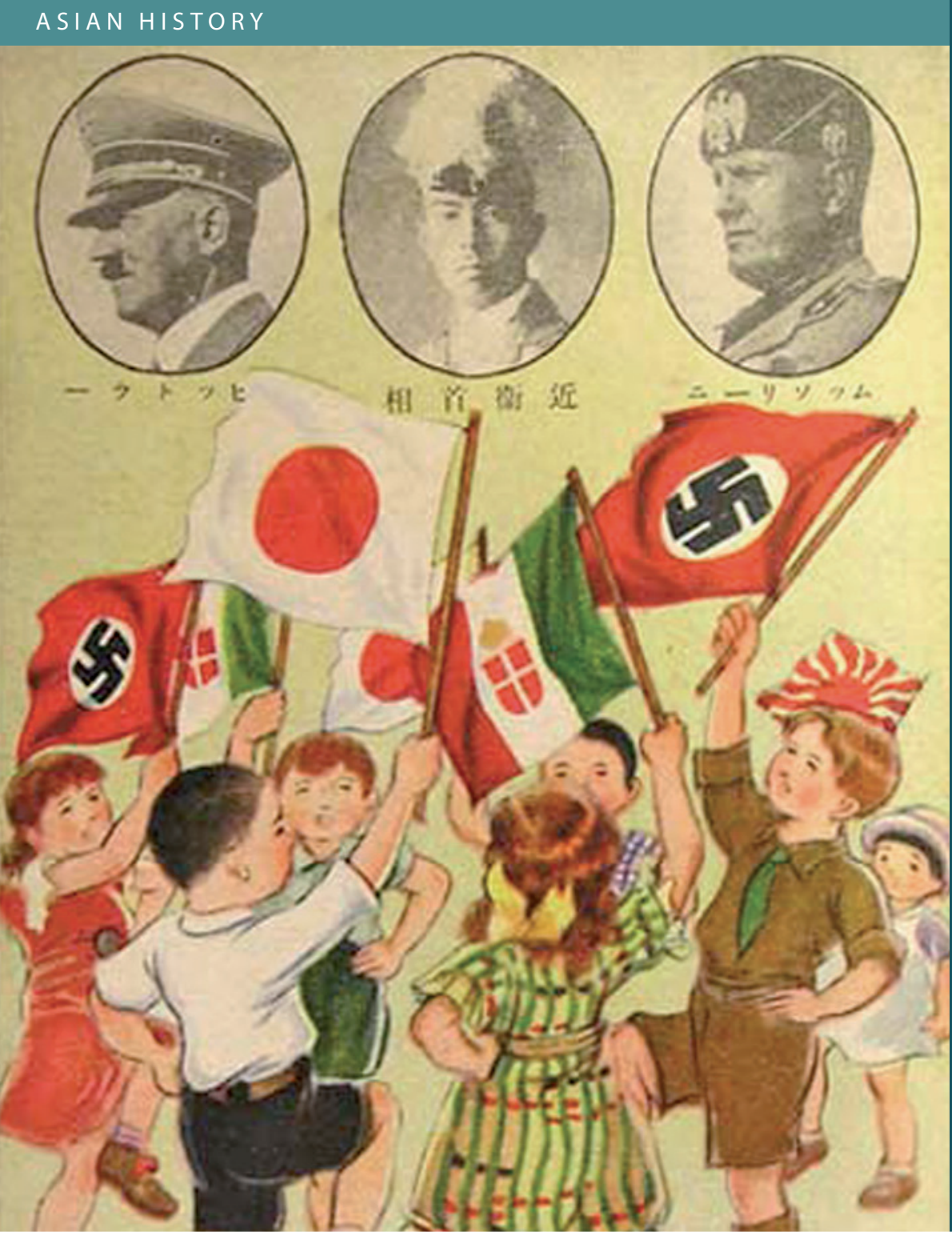

Edgar A. Porter and Ran Ying Porter

\title{
Japanese Reflections on World War II and the American Occupation
}


Japanese Reflections on World War II and the American Occupation 


\section{Asian History}

The aim of the series is to offer a forum for writers of monographs and occasionally anthologies on Asian history. The Asian History series focuses on cultural and historical studies of politics and intellectual ideas and crosscuts the disciplines of history, political science, sociology and cultural studies.

\section{Series Editor}

Hans Hägerdal, Linnaeus University, Sweden

Editorial Board Members

Roger Greatrex, Lund University

Angela Schottenhammer, University of Salzburg

Deborah Sutton, Lancaster University

David Henley, Leiden University 


\section{Japanese Reflections on World War II and the American Occupation}

Edgar A. Porter and Ran Ying Porter 
Cover illustration: 1938 Propaganda poster "Good Friends in Three Countries" celebrating the Anti-Comintern Pact

Cover design: Coördesign, Leiden

Lay-out: Crius Group, Hulshout

Amsterdam University Press English-language titles are distributed in the US and Canada by the University of Chicago Press.

$\begin{array}{ll}\text { ISBN } & 9789462982598 \\ \text { e-ISBN } & 9789048532636 \\ \text { DOI } & 10.5117 / 9789462982598 \\ \text { NUR } & 692\end{array}$

(c) Edgar A. Porter \& Ran Ying Porter / Amsterdam University Press B.V., Amsterdam 2017

All rights reserved. Without limiting the rights under copyright reserved above, no part of this book may be reproduced, stored in or introduced into a retrieval system, or transmitted, in any form or by any means (electronic, mechanical, photocopying, recording or otherwise) without the written permission of both the copyright owner and the author of the book.

Every effort has been made to obtain permission to use all copyrighted illustrations reproduced in this book. Nonetheless, whosoever believes to have rights to this material is advised to contact the publisher. 


\section{Table of Contents}

$\begin{array}{ll}\text { Acknowledgments } & 9\end{array}$

Introduction $\quad 11$

$\begin{array}{lr}\text { Preface } & 15\end{array}$

1 "Something Big Was Going to Happen" 17

$\begin{array}{ll}\text { Saiki Goes to War Footing } & 17\end{array}$

Admiral Yamamoto Comes to Saiki $\quad 21$

$\begin{array}{ll}\text { Conflicted Pride } & 24\end{array}$

2 One Million Souls, One Heart 27

$\begin{array}{ll}\text { The Attack } & 27\end{array}$

Rallying the People $\quad 29$

Quiet Doubts $\quad 32$

3 Oita Men Troop to War 39

"Leaving My Hometown" $\quad 39$

A Buddhist Priest's Gift for Hitler 41

Oita Soldiers $\quad 43$

On to Nanjing $\quad 46$

Nanjing Legacy and the Pride of Oita 48

Our Chinese Family Meets the $47^{\text {th }} \quad 53$

Securing Victory and Moving On $\quad 56$

4 The War Expands and the People Mobilize 61

$\begin{array}{ll}\text { Farmers and Fishermen } & 61\end{array}$

Guarding the Emperor $\quad 62$

Empty Urns $\quad 65$

Pure Spirit of the Saipan Children $\quad 66$ 
5 Invincible Japan $\quad 71$

$\begin{array}{ll}\text { Moral Education } & 71\end{array}$

Hiding the Truth $\quad 74$

Military Education $\quad{ }^{76}$

Learning to Kill, Preparing to Die 8 o

The Beatings $\quad 84$

$\begin{array}{ll}\text { Creeping War Weariness } & 89\end{array}$

6 Fire from the Sky $\quad 92$

Prime Targets $\quad 92$

$\begin{array}{lr}\text { April 21, } 1945 & 103\end{array}$

$\begin{array}{ll}\text { No Place to Hide } & 107\end{array}$

Filling the Craters and Building the Shelters 112

7 "I Shall Die with Pleasure" 120

Edgar's Encounter with the Kamikaze Boy $\quad 120$

Oita's Kamikaze $\quad 121$

8 Never-ending Sirens $\quad 127$

$\begin{array}{ll}\text { Cancelling Classes and Evacuating Students } & 127\end{array}$

Dodging Bullets and Delivering Babies $\quad 129$

9 A Hard Price to Pay 132

Child Scouts 132

Easy Targets 133

Taking Revenge: B-29 Is Downed 134

Meanwhile on Okinawa 139

10 Donate Everything 141

Children Join the Army 141

$\begin{array}{lr}\text { Kamikaze Nightmares } & 143\end{array}$

$\begin{array}{lr}\text { The Stench of Death } & 146\end{array}$

11 Eliminate the City 152

Targeting Civilians $15^{2}$

Oita's Heroic Nurse 154

Too Many Bombs, Too few Targets $\quad 156$ 
12 Oita's Advisors to the Emperor

Never Surrender

The Advisors

13 The Lightning Bolt 161

Digging In $\quad 161$

Nursing the Wounded $\quad 163$

No Taste for Invasion $\quad 164$

14 We Didn't Surrender - The War Just Ended 168

The Emperor's Voice $\quad 168$

Poison for the Women 170

Defeated and Sent Home $\quad 170$

$\begin{array}{ll}\text { Ugaki's Pride } & 176\end{array}$

$\begin{array}{ll}\text { Oita Men on the Missouri } & 178\end{array}$

15 Hungary, Confused, and Afraid 180

Waiting 180

Occupation Plans 180

Running to the Hills $\quad 184$

Bartering for Food $\quad 185$

The Passion of a Mother $\quad 187$

$\begin{array}{ll}\text { Suffering Together } & 188\end{array}$

16 The Devil Comes Ashore 190

Getting Acquainted 190

Working for the Americans 193

Searching for Contraband $\quad 194$

Confusion in the Classroom 195

17 A Bitter Homecoming $\quad 198$

$\begin{array}{ll}\text { Demobilized } & 198\end{array}$

Awkward Reunions 200

18 The Occupation Takes Hold 204

Censorship and a New Order 204

Baseball and Chocolate $\quad 207$

The Americans Were So Wasteful 209 
19 Miss Beppu, Crazy Mary, and William Westmorland 212 The Call for Volunteers $\quad 212$

Closing the Houses - Sort Of $\quad 215$

Crazy Mary and Miss Beppu 219

The Korean War and Exit from Beppu 221

Conclusion 223

Chronology of Japanese Historical Events, 1905-1957 227

$\begin{array}{ll}\text { List of Interviewees } & 231\end{array}$

Bibliography 233

$\begin{array}{ll}\text { Index } & 237\end{array}$ 


\section{Acknowledgments}

Writing a book on Japanese history, with a focus on interviews and archival study, demands the support of a core team of cross-culturally sensitive and dedicated people to see it through. We were fortunate to have such a team. Here we want to acknowledge them. First, Kana Nakahara, organizer, interpreter, translator, transcriber, and confidante, joined us from the beginning. She allowed us to worry about the content and direction of our study, while, in addition to her interpreting, translation, and transcribing, made sure we got to the right places, enriched our interview questions and improved our cross-cultural skills. Motoko Sato set up many interviews, interpreting, transcribing, and translating many of them, along with archival documents and wartime newspaper articles. We are very grateful to her for her many efforts. Matthew Barkley, master translator and transcriber, proved essential to the completion of the book due to his professionalism and speed of work. Others assisting in translations and transcribing were Miyuku Toyada-Inobe and Yoko Hsuing. Joel Bradshaw and Edward Shultz read drafts of this work and their comments and suggestions proved essential in improving the book.

There are two men who need special mention. Susumu Yamamoto, a dear friend and tireless supporter, accompanied us to select interviews and historic sights and provided helpful comments on the direction of this work. Ikunosuke Watanabe proved a gold mine of referrals, arranging interviews with his many contacts throughout Oita Prefecture. His kindness and generosity will always be remembered and appreciated. For helping in a myriad of ways we want to acknowledge Nader Ghotbi, Emiko Oonk, Chisato Kudo, Akiko Uematsu, Maiko Cagno, Kuniharo Mumamoto, Yuko Hada, Natsuko Hada, Mamoru Hirata, and the priests of Gokoku Shrine in Oita City. In addition, the archivists and librarians in the Oita Public Library, the Oita Archives, the Beppu Public Library, the Ritsumeikan Asia Pacific University Library, the American Center Library in Fukuoka, and the Usa City Library provided important, sometimes surprising, materials that strengthened the book.

To those who agreed to sit for one, sometimes two, interviews, we cannot show our appreciation enough. Their names are found throughout the book and are listed alphabetically at the end. As we go to press, we know that some of those interviewed have passed away since we met them. We have tried to represent their views as accurately as possible and hope those still living, and those passed on, would find that to be the case. 
Finally, for guiding this book through publication, we thank Saskia Gieling, Jaap Wagenaar and Ed Hatton of Amsterdam University Press; and Hans Hägerdal and Roger Nelson for their guidance, suggestions, and support.

This book is dedicated to the members of our family who experienced the years covered in the following pages. In China, Ran Ying's mother, Ma Ji Sen, and aunt, Ma Ji Feng, saw the war up close and their observations and sacrifices are chronicled here. In the United States, Edgar's father, G. Ray Porter, served in the U.S. Army Air Corps during the war and his uncle, Grant Porter, fought with the U.S. Marines on Guadalcanal and Peleliu. Each of them also survived the war. 


\section{Introduction}

The personal histories of those who experienced the war and Occupation in Japan between the early 1930s and mid-1950s will soon fade away as age takes its toll. With this in mind, the authors decided to chronicle as much of that oral history as possible and to accomplish this in as deep and, at the same time, broad an approach as possible. Deep in the sense that we dug into layers of memory from citizens living in one prefecture in Japan, a place that reflects in both drama and detail the national challenges and attitudes of the times; broad in the sense that we interviewed diverse populations of Japanese citizens encompassing ages and professions across the spectrum of society during the war years. These memories, enhanced by local newspapers and archives, introduce us to the people of Oita Prefecture as they struggled to survive a quarter century of hardship and chaos.

The idea for this book began with two separate but quickly merging interests. Soon after moving to Japan to teach in an international university in Beppu, a resort town of 120,000 citizens located in Oita Prefecture, Edgar discovered that following the close of World War II the United States established a regional Occupation headquarters in Beppu. In what is now Beppu Park, this headquarters remained active for almost ten years, from the end of World War II through the Korean War, as the primary U.S. presence for much of the island of Kyushu. The name of the base was "Camp Chickamauga," after the Civil War battle fought in Edgar's native state of Tennessee. Visits to the park, as well as the local library, brought forth information and materials to motivate a historian to dig deeper.

At the same time, Ran Ying was engaged as a volunteer at the Beppu Foreign Tourist Information Office, located in the center of town only a few blocks from the park. Her fellow volunteers were retired businessmen and teachers from the area, all of whom spoke English. Over dinner for several months Ran Ying would recount the stories these men and women shared with her about their lives during the war and Occupation. As these captivating stories kept coming, we began to see the richness of a more complete study and shifted our focus from that of the U.S. Occupation to one combining the daily life of those experiencing both the war and the Occupation as it had transpired in this coastal prefecture on Japan's southeastern coast.

The motivation to pursue this research was driven by the opportunity to let people tell their own stories, with little overlay of hidden agenda from the two of us. We knew this to be important and difficult, for we each represented countries most impacted by Japan's expansion into Asia and 
the Pacific, namely China and the United States, and we each had family members who had found themselves face to face with Japanese aggression. Edgar's uncle fought with the U.S. $2^{\text {nd }}$ Marine Corps at Guadalcanal and Peleliu, and Ran Ying's family, including her mother, became refugees from advancing Japanese troops immediately following the Battle of Nanjing in late 1937. Edgar's uncle survived the war, while Ran Ying's family lost several members during their evacuation, including her grandfather. Thus, while we share our views of the consequences and legacies of the war from our perspective in the conclusion, we did not want our interpretation of the lives of Japanese citizens during the war to be colored by our preconceived personal biases. This was made all the easier because as we each made friends throughout the city and prefecture, we were struck by their willingness to share their stories and, at the same time, by the warmth and charm of the people around us. We wanted to introduce these everyday Japanese lives to an audience that remembers wartime Japan through the limited and foggy lens of a few events only, namely, Pearl Harbor, the Bataan Death March, Hiroshima, Nagasaki, and the surrender on the battleship Missouri. Our aim was to present another side of the story, one that focuses primarily on a period dominated by harsh militarization and xenophobic nationalism. We would invite them to express how the war had changed their lives and give their own reflections about and interpretations of those events. So we began, with Ran Ying first approaching her colleagues at the Foreign Tourist Information Office to inquire if they would agree to be interviewed. He agreed and in the end no one we approached declined. Following Edgar's experience in previous oral history projects, this proved unsurprising, as almost universally people enjoy sharing their life stories.

Preparing for this research, we understood the daunting task faced with recording and recounting oral history. Our oral history methodology is most closely aligned with grounded theory, an approach to research that originated in sociology and was outlined by Barney Glaser and Anselm Strauss. "In its original form, it is an insistence that researchers come to a chosen topic without a hypothesis or preconceived notions. As research continues with a person or group, scholars can form their conclusions or hypotheses by analyzing data as they gather them and reinterrogating their information to see what insights they can gain." This can be summarized as: "A researcher does not begin a project with a preconceived theory in mind.... Rather the researcher begins with an area of study and allows the theory to emerge from the data."

1 Mary A. Larson, in Handbook of Oral History, ed. Thomas Lee Charlton, Lois Myers, and Rebecca Sharpless (Walnut Creek, CA: Alta Mira Press, 2006), p. 119. 
One overriding concern for any historian engaged in oral history is that of memory reliability. Memory is selective and over many years it becomes largely a reconstructive exercise; even to the point of telling of stories that may in fact have happened to someone else, or which one hears about and integrates quite unknowingly into his or her own history. We presume this "imagination inflation" found its way into some of the stories we heard and recount in the following pages. ${ }^{2}$ With this in mind, however, it is clear to us that the overriding themes and particulars that arise from this oral history make for a compelling and accurate interpretation of events from the period addressed. Except in rare exceptions we did not discover a Rashomon phenomena where different people viewed similar events in wildly different ways. The legacies and evaluations of these events, and, in fact, the moral values placed on them, do diverge, however, in several cases.

Prior to the first interviews, a list of questions was prepared that gave direction for the interview in a general sense, i.e., the topic would stay as much as possible on the war and Occupation years, while at the same time allowing for recollections to take the interview off in directions surprising, yet captivating at the same time. Each interviewee received the same list of questions, no matter the age or experience during the war. From there the interviews flowed depending on the specific experiences. For example, some were soldiers, so their battlefield experiences took the basic questions in that direction, while others too young to remember much of the war years were allowed to discuss what their parents had told them, and then jump to the questions related to the Occupation years where memory was firsthand. This approach follows the "thick dialogue" process utilized by the oral historian Alessandro Portelli, which requires "a flexible interview approach, but not the point of noninterference. 'In thick dialogue, questions arise dialectically from answers."”3

To build our interview list we depended initially on our own network, as described above. We then moved to "opportunistic recruiting" with the assistance of our friends' and colleagues' networks. From there the list of those to interview snowballed as introductions led to more introductions until over 40 people had been interviewed.

Interviews proceeded with the assistance of interpreters and translators when, as in most cases, the interviewees spoke little or no English. For this project we had the good fortune to have four professional interpreters and

2 Carole Wade and Carol Tavris, Invitation to Psychology, $4^{\text {th }}$ ed. (Upper Saddle River, NJ: Pearson Education), pp. 266-269.

3 Larson, p. 119. 
translators working with us. They not only set up the interview schedules, but forwarded in advance the list of questions in Japanese to those requesting them and accompanied us to the interviews. All interpreters were Japanese. This was essential to ensure that the introduction of the two foreign interviewers proceeded with proper Japanese protocol and etiquette, which is especially important when visiting those of advanced years. Following the protocol formalities, the interviews began with an introduction by the interviewers, stating the reason for pursuing this study and showing appreciation for allowing us to talk with them. Most interviews took place in private homes, with some in business offices and community centers. Interviews lasted between one to two hours each. In all cases the hosts provided Japanese tea, fruit, and sweets. We also presented a gift to each interviewee at the end of the session, usually in the form of sweets. Each interview was taped with the authorization of the interviewee, then later transcribed and translated into English by the team of interpreters and translators.

It is the hope of the authors that the stories that comprise the bulk of this book, combined with original histories and media accounts of the times, will help the reader gain a more complete understanding of the impact the war had on families living in Japan during those horrific years. It is only through listening more, and lecturing less, that real dialogue can take place and greater understanding finds room to grow. 


\section{Preface}

Oita Prefecture sits tucked away on the eastern shore of Japan's southern island of Kyushu. Historically, quiet fishing villages dotted this coastline while farmers cultivated rice and sweet potato in the farmlands edging up to the surrounding mountains. Starting on the southern coastal tip of the prefecture lies Saiki, and moving north one finds at intervals of a few miles Oita City, Beppu, Hiji, Kitsuki and, eventually, Usa and Nakatsu. All were destined to play intriguing, important and, at times, historic roles in Japan's war effort. In all cases the lives of people in these small towns, and dozens of hamlets in between, have rarely been shared outside the home and occasional local archives.

Even to this day, most Japanese outside Oita think little of the place, as though it is an afterthought in any conversation about Japanese culture and history. But between the years 1934 and 1945, these villages and towns were awash in Japanese military activities that transformed the lives of common fisherman and farmers into both observers and participants in what began as a glorious adventure and ended in earth-shattering destruction, disillusionment, hunger, and death. This is their story, told through the words of those who survived and eventually overcame the misery of defeat. It is, surprisingly, the story of a place that played a crucial role in the beginning of the war and was a place from which the last attack on the United States forces in the Pacific originated. Immediately following the war it continued to play an important role, as the small resort town of Beppu, which had been spared from any direct bombing, served as a regional headquarters of the American Occupation. 
Map 1 Map of Japan highlighting location of Oita Prefecture (大分県)

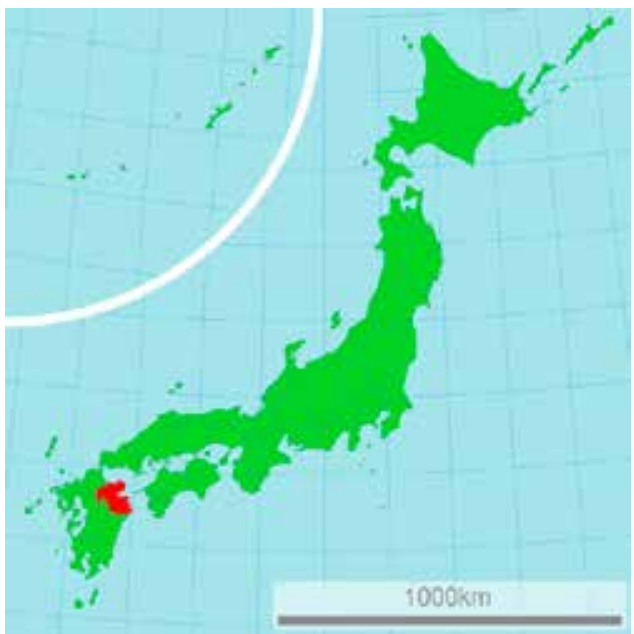

Map 2 Map of Oita Prefecture highlighting key locations during the war

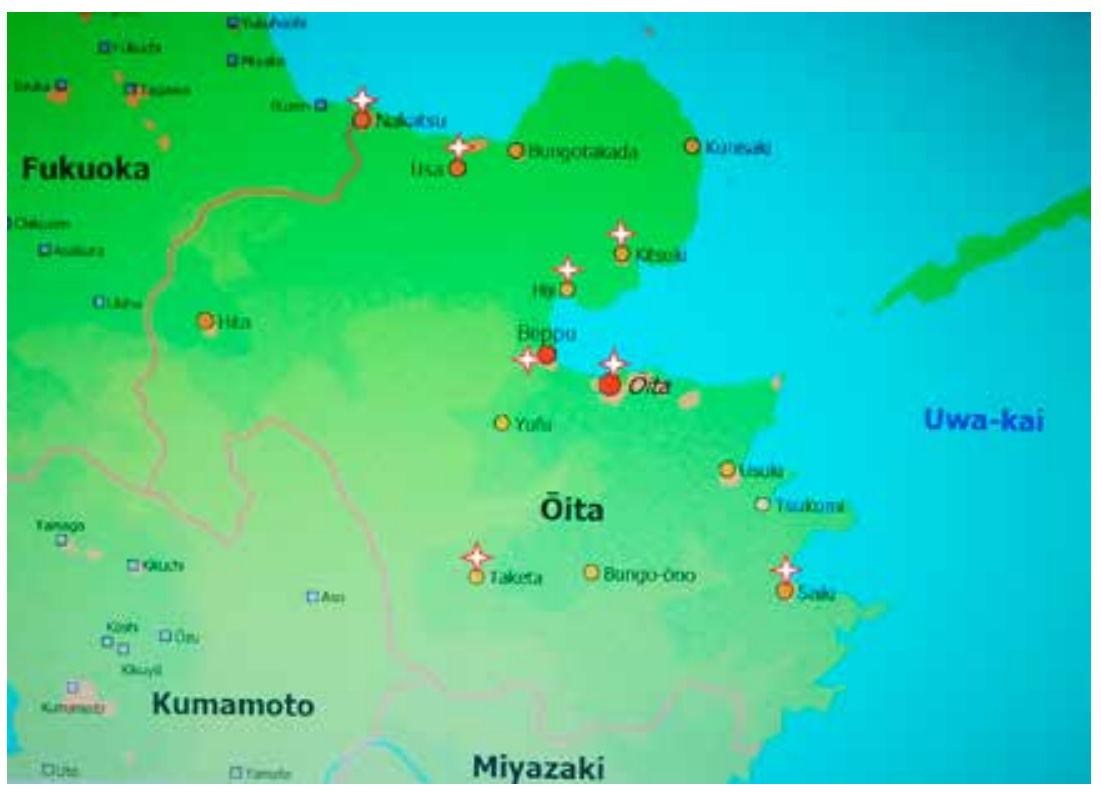




\section{1 "Something Big Was Going to Happen"}

\section{Saiki Goes to War Footing}

Kou Takeda remembers seeing aircraft carriers and navy planes coming and going from his hometown of Saiki as a child. "I was born in 1929. The naval air force base construction was completed when I was five years old. My father took me to the opening ceremony. The naval headquarters was the first building the local residents had ever seen made of concrete and steel. When the war started with China in the 1930s, Saiki was the home base of most of the navy planes that attacked China." To young Kou, war seemed an exciting and romantic prospect, with young pilots dashing around town during training breaks visiting the restaurants and entertainment district in town. At the time, China seemed a faraway land occupied by Japan, while Pearl Harbor had never been heard of. But that would soon change.

The decision to build a new naval base in Saiki was made after the 1931 Manchurian Incident. This event, the bombing of a section of the Japanesecontrolled South Manchuria Railway line in northeast China, was staged by Japanese Army officers under the leadership of Colonial Kanji Ishiwara of the Kwantung Army, who then publically accused Chinese troops of detonating the bombs. Thus began a new era of warfare. "Once started, the Manchurian Incident set off a chain reaction of international and domestic crises that interacted and fundamentally altered the whole trajectory of Japanese state development. China immediately sought redress before the League of Nations; the Kwantung Army sought reinforcements." There was confusion in Tokyo's Imperial Palace, as the emperor knew the event was staged, but he soon yielded to the army and allowed the story of Chinese sabotage to serve as the official story. By October, just two weeks after the incident, most Japanese rallied behind the military leaders and the impending slaughter moved closer. ${ }^{2}$

This rush to war found enthusiastic support in the national press, as described by historian Eri Hotta:

At the beginning of the Manchurian campaign, Prime Minister Wakatsuki Reijiro and Foreign Minister Shidehara Kijuro, among others, wanted

1 Herbert P. Bix, Hirohito and the Making of Modern Japan (New York: Perennial, 2001), pp. 235-236.

2 Ibid., p. 240. 
to contain hostilities. Japanese public opinion, however, fueled by the jingoistic media, keenly supported Ishiwara's adventures. The public was fed reports commending the courage of the field army, swelling national pride. Major newspapers competed with one another, issuing extras with exclusive photos of Japan's every strategic move, profiting greatly from their suddenly booming circulation. Correspondents were sent to war zones to report under such dramatic headlines as "Our Army Heroically Marches from Changchun to Jilin” and “Our Imperial Army Charges into Qiqihar, Its Great Spirit Piercing through the Sky!"

The papers at this time made a conscious political choice that would haunt them in the coming decade: self-censorship. Despite their knowledge, passed on to them in private by some army officers, that the supposedly Chinese-orchestrated bombing was a sham, all the major newspapers chose to withhold this information.... Cornered by what seemed like unequivocal public endorsement, forced in no small part by such newspaper coverage, Wakatsuki's government, on September 24, grudgingly approved the military operations. ${ }^{3}$

Such self-censorship, coupled with an increasingly direct military censorship, controlled public opinion for the next fourteen years, and, as we shall see, the newspapers of Oita played their part with enthusiasm.

Saiki, which had served as a military training area since the mid-1920s, was chosen as a site to upgrade naval and air military readiness because it already had some degree of military infrastructure. Just as crucial, Saiki's proximity to the eastern coastline of the country and its deep water port provided opportunities for training Japan's growing naval and air forces while strengthening defense fortifications. The base formally opened on February 15, 1934, the day young Kou joined his father at the ceremony. Citizens of Saiki and surrounding towns were proud of the newly enhanced reputation this brought to their community and of the economic benefits it would bring. The local Oita newspaper heralded the event with these words, "The newest addition to the air corps will bring added protection to the nation. The local residents of Saiki City raise their hands in praise."

3 Eri Hotta,Japan, 1941 (New York: Alfred A. Knopf, 2013), p. 45. These headlines show lack of knowledge in Chinese geography, as Changchun is the capital city of Jilin and not a different place.

4 Itsuo Hoashi, Asia and the Pacific War and Air Raids on Oita (アジア・太平洋戦争と大分の 空襲) (self-published, 2008), pp. 62-63. Author's address: 1-Chome 3-11, Soda Kita-Machi, Oita City, Oita Prefecture, Japan; the book can be found in Oita Prefecture Library. 
Soon another Oita coastal town, Usa, was also transformed into a military training center, as Japanese militarism moved into high gear. Naval officers visited the town in 1937 to scout out a site for a new air field. They met with the mayors of three small villages - Yanogaura, Ekkan, and Hachiban - and directed them to inform their residents that parts of each village would be transformed into a naval air base. They were to ready themselves to help construct the base and feed the naval personnel, who would fill seven barracks. This news was not altogether welcome to the mayors or their citizens, but they had no choice, and life in this quiet community by the sea began to change dramatically. Women and children joined the men in building the air base, and the villagers who had their land stripped from them began building water lines to the base, moving their agricultural fields to new sites and relocating their families to new dwellings. On October 1, 1939, the Usa Naval Air Base opened as a new home to fighter planes and bombers that began training for air battles, dipping and diving above the heads of the villagers. ${ }^{5}$ The base would eventually play an important role in the coming war with the United States, in part as a training and departure site for the Special Attack Force (kamikaze unit) that would be stationed there.

Oita was moving onto a war footing, with Saiki leading the charge. By early fall of 1941, military activity had increased in Saiki as war with Western countries grew nearer. Kou Takeda remembers, "When I was in the $4^{\text {th }}$ or $5^{\text {th }}$ year of elementary school, more and more ships and planes came into Saiki Bay. They came gradually, though. I also noticed that the airplanes had changed. These were not the planes that attacked China and that we had gotten used to seeing. These new planes were small but speedy, quite different from the old ones. They were Japan's 'new aircraft,' the Zeros."

As ships and planes anchored in Saiki, training commenced in Usa, just over 100 kilometers north, for the larger bombers that would join the Zeros in the coming attack on Pearl Harbor. ${ }^{6}$ But Oita's preparation for war did not stop with air power, as another new type of weapon was introduced in the summer of 1941. In an early omen of what would evolve into a culture of strategic suicide missions during the war, midget submarines began training in the waters off Saiki. Speaking to American military intelligence officers just after the war in Tokyo on October 15, 1945, navy captain Yasuji Watanabe, former aide to Commander in Chief of the Combined Fleet Admiral Isoroku Yamamoto, stated that leading up to the Pearl Harbor attack "we

5 Ikuo Matsuki, ed., The World of Usa Air Force II (宇佐航空隊の世界II) (Usa: Toyonokuni Usa Academy, Soei Hirata, 1992), pp. 14-16.

6 Interview with Morimasa Yonakawa, Tokyo, June 11, 2012. 
had studied and trained to attack in shallow water with torpedoes. They were special torpedoes to run shallow. We had trained for four months, since August 1941, at Saiki." He informed his American interrogators that the use of these midget submarines was intended solely for the Pearl Harbor attack and was implemented in part as a moral boost for young naval officers who wanted to show their bravery for Japan. ${ }^{7}$ From fighter pilots to midget submarine crews to bomber pilots, the people of Oita witnessed historic activity as Japan prepared for an expanded war. They just did not know the full force of what awaited them at the time.

Despite the thrill of seeing the pilots and officers around the town of Saiki, relations between local citizens and the military were distant. Kou Takeda recalls that even though villagers paddled their small boats out in the bay to sell vegetables to the sailors living on their ship,

there was little interaction between the sailors and local citizens. Bars and restaurants welcomed them; however, they couldn't spend a lot of time and money there, because they had curfews and must return to their ships at a certain time. Only commissioned officers were allowed to stay on shore overnight in Japanese-style inns. When the sailors came in town, though, citizens wanted to pay tribute and encourage them to do a good job for the country. But most of them just went straight to the brothels, where they'd queue up. So residents had mixed feelings toward those soldiers. But they were protecting our country and that was honorable, so no one would criticize them.

Just up the coast from Saiki lies Beppu Bay, which fronts Oita City, Beppu City, Hiji Town, and other small fishing villages and ports. Seiichi Kogo was an elementary school student in Oita City in the late 1930s and early 1940s. He was thrilled to see large ships enter the bay. He recalls:

I remember thinking something big was going to happen. About a month before the attack on Pearl Harbor, there were sailors everywhere in Oita. We didn't know it at the time, but it hit me later that they were the ones that trained in Saiki; then went to Hawaii. Near my house was a restaurant and the navy men would often have their dinner there. On educational tours with school classes, students would board and visit the ships.

7 “Interrogation Nav 13, Captain Yasuji Watanabe," 15 October 1945, World War II Database, http://ww2db.com/doc.php?q=194. 
I found out later that the ship that I was on sank in a battle off China. After the war in the Pacific began, educational tours to those ships stopped.

\section{Admiral Yamamoto Comes to Saiki}

What young Kou and Seiichi and their fellow citizens did not know at the time was the fierce behind-the-scenes discussions going into the plans to bomb Pearl Harbor, and the role this small, rural coastal town was to play in the attack. By the fall of 1941 plans were underway to start the war, even while negotiations continued in Washington, D.C., and despite the fact that no final order had been given to attack the Pacific Fleet in Hawaii. On October 20, Saiki hosted a strategic gathering of the chiefs of staff of the Sixth Fleet, the First Air Fleet, and the skipper of the newly built super aircraft carrier Yamato. The outcome of this meeting set Japan on a heightened war footing and presaged a new phase in preparation for the coming battle. The next morning, October 21, Saiki woke up to assault training involving submarines and planes. However, the early training was chaotic. The local commander, Admiral Matome Ugaki, found the pilots largely untrained with accidents occurring at an alarming rate during practice runs. Admiral Isoroku Yamamoto, appointed to command the coming attack, made periodic visits to Saiki to gauge the progress of the training, while overseeing an alternate training site in Kagoshima, at the southern tip of Kyushu. Despite the problems, Admirals Yamamoto and Ugaki knew that war was coming, and they worked feverishly to prepare their troops. On October 29, Admiral Ugaki wrote in his war diary that he had arranged a dinner for new southern area army staff visiting with him and Admiral Yamamoto in Saiki. ${ }^{8}$ Communication between the two branches of the military was surprisingly limited and each was suspicious of the other. This was an attempt to open better communication and share plans as war approached. It is not likely many people in the town knew who was attending the dinner. When asked if he ever saw Admiral Yamamoto in Saiki, Kou Takeda recalled, "No, it was all a secret, but the cars carrying high-ranking officers, such as Admiral Yamamoto, had flags and security guards to accompany them, so we could guess."

By early November 1941, Admiral Yamamoto showed his impatience with both the national leadership and his own training conditions. He had

8 Matome Ugaki, Fading Victory: The Diary of Admiral Matome Ugaki, 1941-1945 (Pittsburgh: University of Pittsburgh Press, 1991), pp. 12-18. 
already clashed with his superiors, having advised against war with the United States in the first place, and voicing his opposition to the recently signed Tripartite Treaty with Nazi Germany and Italy. But he was ignored. War was inevitable, and he was the man chosen to lead the initial strike. Ever the professional commander, Yamamoto threw himself into finding a way to protect Japan. He proposed his plan to attack Pearl Harbor and disable the U.S. Pacific Fleet headquartered there. Anticipating approval, he sped up the training exercises in Kagoshima while conferring with Admiral Ugaki in Saiki. But as the days went by, he grew anxious on multiple fronts: Not only had his plan to attack Pearl Harbor yet to be approved, but he worried about the effectiveness of the training in Kagoshima as he waited restlessly for the final order to proceed. He realized that the training exercises in Kagoshima had to be moved, because the topography was not close enough to that of Pearl Harbor to provide effective strategies for attacking the U.S. fleet, and he despaired over his pilots being unprepared in the coming attack. Mock air attacks, for example, were made from too far out at sea in Kagoshima and the harbor was poorly situated for replicating the placement of American ships in port.

Yamamoto's bold plan to attack Pearl Harbor aimed to cripple the U.S. fleet and air power, fearing that without such a knockout blow the United States could gather enough strength to defeat Japan within two years. Even by the end of October there was much opposition to his plan. On November 1, he was called to Tokyo, where he argued his position once again, threatening to resign his commission as commander in chief of the navy if his Pearl Harbor strategy was not formally approved. At this emergency meeting, the highest military and governmental authorities finally gave in and ordered him to make final preparations for the attack. Upon gaining this confidence, he ordered that the training for the attack be moved immediately from Kagoshima and centered on Saiki.

If one visits Saiki Bay even today it is easy to see one of the reasons for the change. Like Pearl Harbor there are hills close by for pilots to be wary of, and just off the coastline stands a small island, mimicking Pearl Harbor's Ford Island, the docking site of many U.S. battleships, including the Arizona. Despite the short time between the current training period and the projected attack date of December 8 (Japan time), Yamamoto received final clearance to relocate the air attack training exercises to Saiki. Almost immediately, preparations for the attack hit their stride.

Just after midnight on November 3, orders went out for horizontal bombers, dive-bombers, and torpedo bombers to take off from the six aircraft carriers in Kagoshima, fly several hundred kilometers north, and attack 
targets designated in Saiki Bay. Their early morning mission was aligned with the expected attack timetable set for Pearl Harbor only weeks later. These exercises were repeated over the next two days. When asked if he was satisfied now, Yamamoto replied, "Yes, I'm sure we can do it now." Concurring with that optimism, Admiral Ugaki reported from Saiki that "masses of planes attacked the ships in anchor. Much progress was noted in their skill. ${ }^{{ }^{10}}$ Observing from the coastline, a young and wide-eyed Kou Takeda witnessed the practice runs, recounting, "I remember when the airplanes started practicing in full force. Those airplanes, both bombers and fighters, flew very close to the sea, coming over Saiki Bay and Naval Air Force headquarters, which served as a target for their attack."

On November 5, while berthed in Saiki aboard his flagship Nagato, Admiral Yamamoto drafted a long and detailed outline of the coming battle, titled, “Combined Fleet Secret Operational Order No. 1." It began, "The Combined Fleet's operations in the war against the United States, Britain, and Holland will be put into effect as detailed in the accompanying booklet."11 On November 17, after weeks of training exercises by pilots and naval crews and hectic last-minute planning by Yamamoto and his officers, he boarded the ship Akagi in Saiki, which was to lead the attack on Pearl Harbor. The admiral addressed the crew on board this ship, speaking especially to the flying officers who would constitute the first wave of pilots to bomb Pearl Harbor. He praised them, but warned that Japan was facing a strong enemy, the strongest in the history of Japanese history. They expected to surprise the enemy, but they should be prepared for strong resistance.

The day to launch the attack was fast approaching. Training intensified, and while now more organized and effective, it was fraught with danger. One officer from a ship in the bay described the dangerous conditions they faced as they pushed the limit of their planes and pilots. "An old submarine was docked, and pilots practiced flying over a hill, then swooping down low and within 800 yards of the target before swerving off sharply. They even trained at night, so there were a lot of accidents. ${ }^{{ }^{12}}$ Sailors and pilots aboard the ships in Saiki could sense the tension as frantic and last minute preparations were put in play. Former navy captain Eiichi Choh recalls, "a new torpedo just developed by Mitsubishi for use in the shallow waters of

9 Hiroyuki Agawa, The Reluctant Admiral: Yamamoto and the Imperial Navy (Tokyo: Kodansha International Ltd., 2008), pp. 235-236.

10 Ugaki, pp. 20-21.

11 Agawa, p. 237.

12 Leslie Helm, "Reunion at Japanese Port Marks Pearl Harbor Attack," Los Angeles Times, December 6, 1991, http://articles.latimes.com/1991-12-o6/news/mn-497_1_pearl-harbor. 
Pearl Harbor had to be rushed onto the carriers direct from the factories shortly before the fleet departed. ${ }^{{ }^{\prime \prime}}$

Then they vanished, like ghost ships that come and go without warning. Early on the morning of November 19, the fleet sailed out of Saiki Bay heading to the northern Japanese islands in the Kuriles, where the attack forces would rendezvous. Mr. Takeda remembers getting up that morning, expecting to see the aircraft carriers and accompanying ships still sitting in Saiki Bay, as they had off and on for the past many days. But "they had all disappeared and when I heard later about the Pearl Harbor attack, then I thought the ships must be the ones that went on that attack."

After arriving in the Kuriles, the pilots and seamen on the ships from Saiki and the rest of the combined attack force awaited orders. On November 25 , Yamamoto ordered the strike force to advance on Hawaii and prepare to destroy the American fleet; confirmation of the exact date of the attack would follow. At 6 p.m. on the night of November 26 the fleet departed for Hawaii. ${ }^{14}$ But Saiki was not yet finished contributing to the attack, as explained by Misayo Hamasaki, curator of the Saiki Peace Museum. "Some submarines left for Hawaii directly from Saiki, not the Kuriles. They arrived early to reconnoiter Pearl Harbor secretly and assist any pilots shot down during the attack. These were newly constructed, two-man submarines attached to larger submarines for most of the journey." All of these midget submarines were lost, as were their crews.

\section{Conflicted Pride}

For decades after the war the people of Saiki expressed frustration that their small port town never received the attention or credit for the role it played in the attack on Pearl Harbor. While this may seem odd to those who find little to admire about Japan's attack, which began a new phase of world war, pride in the attack still lingers. This was highlighted during the $50^{\text {th }}$ anniversary celebration of Saiki's contribution to the success of the attack. On December 6, 1991, a Saiki youth group staged a symposium, exhibit, dinner, and tour of the harbor to commemorate Saiki's role in world history. Addressing hundreds of participants were former Zero pilots, submarine

13 Ibid.

14 Edwin P. Hoyt, The Last Kamikaze: The Story of Admiral Matome Ugaki (Westport, CT: Praeger, 1993), pp. 11-12. 
captains, and the son of Admiral Isoroku Yamamoto. The young people listened intently to these heroes of Japanese military daring.

The keynote speaker was Kennosuke Torisu. Torisu had led the Japanese Navy's "human torpedo" initiative, a late war effort that placed one suicide volunteer inside a one-person submarine with explosives in its prow. The most popular speaker of the day was Kyozo Makino, a Zero pilot turned postwar businessman. His remarks roused the crowd of over 400 with his defense of Japan's attack as a necessary act of self-defense. "Before the war, only four countries in Asia had independence; after the war they were all independent," Makino said. "That's because Japan pushed the whites out of Asia." Taking his argument to postwar consequences, he further argued that America assisted Japan in rebuilding solely because "it recognized that the true enemy was communism, and it felt bad about having gone to war with Japan.... We must teach our youngsters that we were not the aggressors in the war." ${ }^{15}$ At the time of his presentation in 1991, Makino held the position of chairman of the Japan America Society in the neighboring town of Beppu, starkly illustrating the incongruity of such postwar sentiment exhibited by many Japanese.

Toward the end of the day's celebrations, the romanticism of the attack and of Japan's naval prowess was enhanced by the memories of those who had participated. The reputation and image of Admiral Yamamoto is a case in point. Participants in the celebration toured a local historic home, where former navy captain Choh guided them to a tatami room where Yamamoto used to rest during his visits to Saiki. "Was he as dashing a man as he is pictured in the movies?" asked one visitor. "He was like a god," said Choh. "He was Japan's hope." The admiral's son, closer to the man than any others eager to idealize him, tried to bring the discussion back down to earth. "He was really pretty short," he responded. ${ }^{16}$

The isolated port town of Saiki had not finished commemorating its historic role. In the mid-199os, townspeople established a museum there to highlight the Pearl Harbor attack, and at the same time to show the daily life of the people who lived there during the war. When visiting this museum, one is struck by the seemingly contradictory messages it conveys. On the one hand, the museum sits just across the road from Saiki Bay, and directly across from the small replica of Ford Island that Zero pilots used for training exercises. Video and still pictures of the Japanese naval force in port during those years and of the actual attack on Pearl Harbor are at 
the center of the exhibition. However, it does not stop there, as the lives of common people during the war years are starkly exhibited. The lack of material for clothing, the lack of food, the lack of metal for anything other than military use, and the records of American bombing campaigns on Saiki are stark reminders of those years. The museum is in fact called the "Peace Memorial Museum," suggesting that the war was not glorious, but brutal and not to be repeated. When visiting the museum for the first time, upon learning that the authors' home was in Hawaii, the now elderly but active museum advisor Kou Takeda apologized for the "unfair attack" on Pearl Harbor. When discovering that Ran Ying was originally from China, he also offered apologies to her for the cruelty of the Japanese military in China. This is not a man to romanticize the attack on Pearl Harbor or the goal of Japan to save all of East Asia from the North Americans and Europeans. At the same time, he remained proud to have shared the role Saiki played in the war effort and to recall those childhood days when he was enthralled with the sailors and ships he saw every day. Saiki is a perfect representation of the contradictions Japanese exhibit toward the war. 


\section{$2 \quad$ One Million Souls, One Heart}

\section{The Attack}

On December 2, the First Air Fleet aboard the flagship Akagi received the formal order to "Climb Mt. Niitaka," the signal to proceed to Pearl Harbor for the lead attack. On December 6 the First Air Fleet proceeded to refuel their planes and the Akagi raised the $\mathrm{Z}$ flag, the de facto national flag with the red sun centered against a white background. ${ }^{1}$ At 6:00 a.m. on December 8 (Japan time) the First Air Fleet launched the first wave of attack. At 7:00 the next wave left the Japanese aircraft carriers. At 7:48 the planes arrived at their target. The attack began by bombing and strafing first the military base of Kaneohe. Then the leader of the attack force signaled to his pilots "To, To, To," giving the order to begin bombing the principal target, Pearl Harbor. Five minutes later he sent the message "Tora, Tora, Tora," the signal that the attack was not opposed and success had been achieved in surprising the enemy. By 10:0o the first wave of attackers had returned to their carriers. The attack continued for the next several hours, however, as full-size I-70 as well as midget submarines targeted military bases around Oahu. At 1:15 the Japanese command ordered the attack to break off, and the fleet began returning to port, leaving the occasional submarine to harass American ships in the area. ${ }^{2}$

Years later, Yuji Akamatsu, one of the pilots trained in Saiki who worked in his family fish paste business after the war, sat eating and drinking as he recalled the attack for young people asking about his exploits. Enjoying his replenished cup of sake, a relaxed and smiling Akamatsu began, "It was really no big deal. Enemy fire in those days was so inaccurate; it wasn't that dangerous.... The only scary part, he said, was "coming over the mountain, flying so close to the ground that the trees swayed from the turbulence created by the plane's propeller. We got so close to the ships, there was really no chance of missing." ${ }^{3}$

The damage done by the surprise strike was heavy, but results proved far from perfect, as the American aircraft carriers were not in port at the time

1 The date of attack in Japan was December 8, while it was the morning of December 7 in Hawaii. The date was chosen in part due to the assumption that a Sunday morning would find the U.S. fleet relaxed after a late Saturday night.

2 Michael Slackman, Target: Pearl Harbor (Honolulu: University of Hawaii Press, 199o), pp. 289-294.

3 Quoted in Helm. 
and thus not taken out. Final figures show that a total of 2,403 members of the military and civilians in Hawaii died in the raid, most of them navy personnel. Three ships were totally destroyed: the battleships Arizona, Oklahoma, and Utah. Serious and moderate damage was inflicted on more than a dozen other ships, but eventually most of them returned to fighting shape. A total of 162 U.S. aircraft were destroyed, mostly on the ground. Meanwhile, Japan lost 29 aircraft, one I-70 submarine, and five midget submarines. Japanese dead were estimated at 129, more than half from the I-70 and the midget submarines. ${ }^{4}$

No one in Japan besides those directly involved in the planning and implementation of the attack had any indication there was to be an attack. They could not know how their world was about the change. Morimasa Yunokawa, a 2o-year-old cadet in the National Naval Academy in Tokyo at the time who would eventually serve in Oita City and Usa as commander of a kamikaze unit, remembers hearing about the Pearl Harbor attack on the radio, just like other Japanese citizens.

None of us at the Naval Academy had any privileged information about the attack. After the public announcement, the students assembled for a general meeting. The head of the academy addressed us. He announced that Japan had begun war on the United States and England. He proceeded to instruct us to continue focusing on our studies and not be distracted by the war. We all knew, however, that we would soon join the fight against these new enemies. I'm sure everyone had different feelings, but I thought, Banzai!! There were a few people who thought going into war against the Anglo-Saxons was a bad idea for Japan. They thought Japan was in danger. Only a few thought this, though. And I was ready.

People in Oita had expected not war, but a peaceful resolution to tension with the United States, at least if they paid attention to the local newspapers. On December 6, for example, the local newspaper reported that negotiations with Washington were heading toward a peace agreement, despite little progress. Everything changed on December 8, when a local radio announcer interrupted regular programming, saying that there was important breaking news and warning, "Do not turn off your radio - This is of utmost importance." The broadcast went on to describe the attack on Pearl Harbor. On December 9, newspaper headlines gave details of the 
attack on Pearl Harbor, as well as simultaneous attacks on Guam, Manila, Hong Kong, and Malaysia. The battleships West Virginia and Oklahoma were destroyed, it said, with four aircraft carriers and four more destroyers heavily damaged. Japan, it reported, lost only a few planes and no ships. ${ }^{5}$ While these initial reports proved exaggerated and erroneous in specifics, success at Pearl Harbor energized the population and everyone was exhorted to defend the country.

The front page of the Oita newspapers, like those all across the country, carried the country's formal declaration of war as presented in the emperor's Imperial Rescript, which justified this expansion of the war against the Western powers as a response to the United States' and Great Britain's threatening behavior toward Japan and their interference in the peace of East Asia, especially China. The call for unqualified dedication from the citizens of the country appears in the final sentence:

We rely upon the loyalty and courage of Our subjects in Our confident expectation that the task bequeathed by Our forefathers will be carried forward, and that the sources of evil will be speedily eradicated and an enduring peace immutably established in East Asia, preserving thereby the glory of Our Empire. ${ }^{6}$

\section{Rallying the People}

Editorials in Oita City newspapers focused on the coming challenges and encouraged the people to prepare for war. One stated:

The negotiations for the continued efforts to assure the Greater East Asia Co. Prosperity Sphere have fallen apart and the United States was trying to prevent us from building it. We were surprised that negotiations did not work out and they tried to stop us. However, looking at history, we have not been dominated and we win wars waged on other countries. We have fought a hundred battles and won a hundred battles in the past five years. Although not an easy decision, we are confident we can win. They see us as a small economy but we are not. In this fight, to support our troops, we will ask for sacrifices because hard economic times may

5 Oita News (大分新聞) (Oita City, Oita Prefecture, Japan), December 6, 1941, pp. 1-2.

6 Japan Times and Advertiser (Tokyo, Japan), December 8, 1942. 
fall on us all. This is a long-term war and you must be prepared. But if we unite as a nation, we will without a doubt be victorious. ${ }^{7}$

The chairman of the Oita City business association released a statement of defiance for the citizens: "We have fought in the Russian and Chinese wars but this is unlike anything we have experienced before. 'One million souls, one heart' is no longer just a phrase but truly represents what we need now. I support our leaders and our nation. This will be a long war but I will be resilient and we will win." The mayor of Oita City was also quoted: "We have gone up against big countries and been victorious before. Now we will be even more earnest as we fight against two of the largest nations."

In the local newspaper of December 10, 1941, the governor of Oita Prefecture issued the following statement, setting the tone for the next four years of war:

At long last we are at war with the unrestrained barbaric British and American nations. In order to establish prosperity and peace in East Asia and protect the existence of our empire, we must wage this war against England and America. Our emperor has addressed this nation with a declaration of war which has been a long time coming. This is going to be a long war that we must endure in a calm and collected manner. With the cooperation of our people, the emperor's invincible army and the government, we will build a trusting relationship, working together to fulfill our ultimate goal. To support the building of Japanese military, we must establish a consistent productive force and a stable economy. For a stable and safe future of Japan, we must carry on the establishment of the Greater East Asian Co. Prosperity Sphere with no delay. ${ }^{9}$

Public support for the war with these new enemies was both highlighted and encouraged through the local press. "It has been a day since the BritishAmerican-Japanese War began. In Beppu, the emperor's declaration of war has ignited the passion of the people, as patients dressed in white from the Beppu Military Hospital and students from the Nankokumin School marched through the night in celebratory prayer. The citizens met throughout the city, strengthening their resolve. Citizens throughout the city feel

$7 \quad$ Oita News, December 9, 1941, pp. 1-2.

8 Ibid. While the attacks on Pearl Harbor were aimed at the United States, attacks in Hong Kong and other British colonies initiated war with Great Britain at the same time.

9 Ibid., December 10, 1941, pp. 1-2. 
angry toward the brazen arrogance of our enemies." This was followed by a call from the newspaper to "join us at Haruki Shrine on December 11 at 14:0o to support the efforts against the enemy countries." ${ }^{\text {10 }}$

Finally, showing an early indication of just how big an impact this war would have on the local populace, especially its school-aged children, the newspaper headlined a story, "Short Summer Break and School on Sundays: Speeding up Graduation for the War Effort." It read, "In order to speed up the graduation of second-year vocational school students, there will be more classes during the summer and on Sundays as well. This will be implemented from the school year starting April 1, 1942. Summer breaks will be shortened to between one and three weeks long and the third school year will begin in January and end in September. Students will attend school on Sundays twice a month."

The attack on Pearl Harbor made striking impressions on the young people in Oita. Takafumi Yoshimura was ten years old and a student in the small town of Usa. When asked to relate his first memory of the war, he recounts:

The date of December 8, 1941, was imprinted in my mind clearly. It was a cold morning, and I went to school as usual. All the students gathered for an assembly in the school yard. The principal announced that Japan was now in a war with America and England. He didn't elaborate on the state of war, but I remember he was tense. I was in the $4^{\text {th }}$ grade in elementary school. I was excited to hear about the war, and it never occurred to me that Japan could lose. At the time, newspapers and radio programs always informed Japanese citizens that Japan was winning, so my family and I believed that Japan would win the war easily.

This was the prevailing sentiment, especially among the school-age children. Tomiichi Murayama, the future prime minister of Japan who was then a school boy in Oita City, gives voice to the unified sense of excitement felt by the boys in his school. "I was just a kid so all I remember was that excited 'Yay!!' feeling."

Toyoki Goto, son of a farmer near Oita City, was in the third grade in 1941. He remembers the Pearl Harbor attack serving as his introduction to the glory surrounding Japan's military might. "I had no idea where Pearl Harbor was. All I knew was that we were fighting a tough war, but really 
I didn't even know what war was. My teacher announced the attack to us and urged us to be ready to die for Japan. During school we drew pictures of the war. All of us either drew pictures of planes flying or soldiers shooting guns. We had nothing else to draw."

Yonosuke Yanase was nine when the Pacific War began. "The teachers told us this, the radio told us this. It was everywhere. At home, my dad read the story from the newspaper to us. We were so excited; everyone in school was excited. For a long time, it seemed we were always winning." Mr. Yanase remembers, "Everything revolved around dying. The teachers would tell us that we were the children of the emperor and Japan, and that dying for the emperor was glorious." This message of glorious, expected death was engrained from the earliest years and permeated the minds and, in so many cases, the determination of these young children growing up through the war. They prepared for a martyr's death.

To reinforce this, a story with accompanying photos celebrating the suicidal death of young naval officers in the Pearl Harbor attack appeared in the youth magazine, School Weekly: Junior Edition, in April 1942. Titled "Nine War Heroes at Hawaii," it reported:

The heroic action of the Special Attack Flotilla which surprised the entire world at the outset of the War of Greater East Asia in the Battle of Hawaii has been revealed. The attack was planned and put into practice by First Lieutenant Iwasa and eight other officers. They carried out a thrilling exploit unprecedented in history and after performing their duties the crews shared the fate with their vessels. ${ }^{12}$

\section{Quiet Doubts}

This glorification of death and martyrdom on such a grand scale was not always prevalent in Japanese society and here it is instructive to take a take a step back and look at the years just preceding the rise of militarism. In fact, a strain of pacifism, or at least restraint and critical reflection on the role of the emperor and the military was not unheard of only a few decades earlier. In a widely read poem striking for its direct challenge to authority written during the Russo-Japanese War by Akiko Yusano, one of Japan's

12 School Weekly: Junior Edition, vol. 73, no. 1, Monday, April 6, 1942. It is worth noting that this was an officially approved publication used for teaching English at a time when speaking English was under attack in some parts of the country. 
most famous and controversial poets in the early part of the $20^{\text {th }}$ century, this sentiment is unqualified:

O My Brother, You Must Not Die

O my young brother, I cry for you

Don't you understand you must not die!

You who were born the last of all

Command a special store of parents' love

Would parents place a blade in children's hands

Teaching them to murder other men

Teaching them to kill and then to die?

Have you so learned and grown to twenty-four?

O my brother, you must not die!

Could it be the Emperor His Grace

Exposeth not to jeopardy of war

But urgeth men to spilling human blood

And dying in the way of wild beasts,

Calling such death the path to glory?

If His Grace possesseth noble heart

What must be the thoughts that linger there? ${ }^{\text {?3 }}$

Akiko Yusano's poem became the anthem for expressions of antiwar sentiment during this earlier war and was put to music and sung in protest meetings. During the consolidation of the militarists in the years leading up to the war in China and the Pacific, the poem was banned and the poet sidelined. It was to reappear after World War II, as recalled by a woman who was a young student at the time. "After the war, the poem by Akiko Yusano was printed everywhere, and we were taught to recite it, but most of us had never seen it or heard of it before, though we later found out how famous it had been before the war years. ${ }^{{ }^{114}}$

Such sentiment never completely died even during the war years, though the nationalist education found in the schools made it very difficult for young people to fathom anything but the glory and supremacy of Japan's leaders and the military. It was certainly forbidden to express doubts as openly as in Yusano's poem. Yet there were small gestures, and questions.

13 Akiko Yosano, “O My Brother, You Must Not Die," http://www.poemhunter.com/ poem/o-my-brother-you-must-not-die/.

14 Interview with Hiroko Takamoto. 
In Shanghai, the father of Shunsaku Nanri, a Japanese trading company executive who had lived all over Asia and now raised his family in that Japanese-occupied city, told his middle school son upon hearing of the attack on Pearl Harbor that Japan was now in trouble and would certainly lose this war..$^{15}$ Back in Oita, where the language of the new enemy was increasingly under attack as a legitimate line of study, one strong principal stood up against this nationalist reaction. A student at the time, Yasuo Tanaka, remembers those days just after the attack:

At first nothing much changed. Soon English class became a problem. I was in the second year of middle school then. Everyone had strong feelings and questioned why we still held English classes, why we needed to learn the language of our enemy. However, at the time there was an English exam for the advanced-level examination, so what should we do? Principal Ono met with the students and said that not to learn English just because it was the language of the enemy was unwise. Because it was the language of the enemy all the more we should master it. In a war situation, he explained, it'd playing into our favor if we could understand what the enemy was saying. He stressed to us that, as students, we should study first before concerning ourselves with the enemy. Preparing ourselves by studying hard was our responsibility. I think Principal Ono's sentiment was not isolated, but people wouldn't voice it in public.

Indeed, comments such as these were rare, especially if made openly. Nevertheless, there were quiet doubts. One example of the conflicted response to the Pearl Harbor attack comes from the family of Masaaki Yano, residents of the town of Kitsuki. Masaaki was born in Canada in 1927, and his sister Megumi soon followed. His father Shizuo, the sixth of eight children, had left Japan in 1923 for a new life. This was no ordinary family he left, as the head of this household historically oversaw much of the cultivated land in Kitsuki, supervising farmers working their fields in this fertile rice-growing region. Akin to a Western manor home, known in Japan as shoya, this house overlooks much of the local farmland sitting above the Yasaka River and sits just next to the Buddhist temple that still serves the local community today.

The departure to Canada was not a popular decision by others in the family, but times were tough in Japan in the 1920 and Shizuo was bored with life in the countryside. He did not worry about abandoning his family, however, as he had two older brothers to take over the family obligations. 
As his son Masaaki recounts, his father "flew" to Canada with his wife and began a business in strawberry production. By all accounts the family was happy there, with Masaaki and his sister growing up Canadian, speaking English at all times except around the house with their parents.

In 1933, however, Masaaki's father was called back to Japan following a family meeting that decided he had to return to Japan and manage the family manor and surrounding lands. Uninformed that such a meeting was to be held, the sudden call to return home to run the family farm proved traumatic to the entire family. The meeting took place because, by that time, all his siblings had taken on other responsibilities.

The eldest son left home as a teacher and the second son toured the world as a military officer. So my father was told to come home, as he was the only one left to take care of the family responsibilities. Initially he was unhappy with the decision, and refused to return. Both he and his wife enjoyed their lives in Canada and wanted to stay there. The family affairs in Kitsuki were of little importance to them. However, as more pressure came, he gave in and our family left our home in Canada.

That is how, in 1933, my father, mother, sister and I moved to Japan, a foreign country to me. I was about to enter primary school. We sailed from Canada to Yokohama on the ship Hikawa Maru. We moved in the house with my ageing grandparents and all the property was transferred to my father. From the beginning I was in trouble with the language. In Canada, my name was Sam, and I spoke Japanese only at home. But now, I had to go to the temple next door to our family home every day to learn Japanese. I started by learning how to write my Japanese name properly, Ya No Ma Sa A Ki, only these six characters. When I entered school, other children made fun of me for my poor Japanese.

Masaaki Yano's introduction to Japan was dominated by one theme. In his small rural school the nationalism in education was unquestioned, including, unlike the experience of Yasuo Tanaka in Oita City, the attitude toward speaking and teaching the language of the enemy. He recounts:

At that time, patriotic education was carried out in all of Japan. I didn't understand much because I was small, but I do remember militarism dominating our lives. At first we heard of victories in China. After I entered high school, Japan attacked Pearl Harbor, and life became even more militaristic. At the time, students were happy, because we won, we won! No, not just happy, but totally thrilled. On the radio, in the school 
and at home, everyone couldn't get over the big victory. Our patriotic fervor switched from against China to against the United States and Great Britain. All things related to our enemies were condemned. English classes were banned. I felt sorry for the English teachers in our school, as they were now in disgrace.

At home the response was much more mooted. "My parents," Mr. Yano remembers, "harbored no ill feelings toward Americans and any Westerners for that matter, for; after all, they'd lived in Canada for ten years. In fact, they missed Western democracy after moving back to Japan. So they didn't mention the war much. You could say they were neutral." The family's position in Kitsuki, however, was further complicated, and at the same time, enhanced, by the second brother, who had abandoned the family business to join the military. This was no ordinary soldier, but a naval officer who had risen to supreme head of all Japanese naval operations before the war. Rear Admiral Teikichi Hori, whose family name was changed from Yano as a child when he was adopted by a neighboring family with no male heir, was one of the best-known persons to hail from Kitsuki. ${ }^{16} \mathrm{~A}$ close friend of Admiral Yamamoto since their days in military school, he had risen to the highest ranks of leadership in the years leading up to the war, including participation in diplomatic negotiations in London and Washington, D.C., in the 1930s. Just prior to the onset of war, however, he resigned from his duties as his positions lost out to those advocating war. His nephew insists that Hori, like his friend Yamamoto, believed Japan could not defeat the United States and the effort should be on reaching a peaceful resolution rather than beginning a war. "However," states his nephew Masaaki Yano, "Hori's way of thinking was considered dangerous among many in the Japanese Navy. He resigned, yes, but really he was fired." Even though there was some concern that Hori was not fully supportive of the war effort (he lived out the war in Tokyo), to be known as a nephew of such a famous military leader gave the young Masaaki not only status among his peers, but also pressure to be excessively patriotic. He had to play the super patriot to show everyone he was up to the task.

In the days following the attack on Pearl Harbor, the Oita newspaper reported the enthusiasm of the entire populace, mentioning particularly the school children. One girl, talking to her friends, said, "Boys will have to

16 The purpose of this adoption was to maintain the family name for the next generation, as there were no sons in this family, but Hori never lived with his adoptive parents and stayed with the Yano family throughout his up bring. 
join the army and fight. They have to be careful fighting such big countries." Word spread that Japan was victorious in not only Hawaii, but also Guam, Hong Kong, Malaysia, Singapore, and Shanghai. Students left school with their teachers and went to the surrounding shrines to pray for the "much needed victory." Students from Iwata Girls High School in Oita City went en masse to the Haruki Jinja Shrine to pray for Japan's future victories. During the shrine visits the mood was somber but, according to the reporter, "the student's resilience was impressive. ${ }^{{ }^{17}}$

Skepticism began to fade even from those who quietly questioned the war when news of these early victories appeared in the press. Even young Shunsaku Nanri's father in Shanghai, an early critic after Pearl Harbor, "soon changed his view when we won so many battles and were successful in conquering so much of Asia. He became patriotic then."

After the attack on Pearl Harbor it was clearly dangerous to question the war anywhere in Japan, and any subtle attempt to do so was an invitation to trouble. This attitude was propagated clearly by the national publication, Bungei Shunju, a forceful voice of militarism, when it issued a clear and stark warning to all who would question the direction Japan now embarked upon, as seen in this editorial:

Unless and until we sweep away every and all influences of democracy and internationalism, we Japanese will not be able to see the truth.... We should eliminate any suspicious thoughts that lurk within academia and the press.... It is Bungei Shunju's position that freedom of speech and publication must be strictly controlled. ${ }^{18}$

The almost total lack of press freedom was assured by the strict oversight of all newspapers and magazines in Japan during these war years. In Oita, military personnel visited the Oita Godo Press offices every day to make final decisions about which stories could be published, and how to present the news in ways that aided in the war effort. Journalist Yasuo Tanaka, writing after the war, recounts how his older colleagues had to approach their job at the Oita Godo Press. "During the war the final decisions about what went into the newspaper was made by the army. Newspapers had to be censored every day before they could be published. We never really knew

17 Oita News, December 9, 1941, pp. 1-2.

18 Quoted in Adam Gamble and Takesato Watanabe, A Public Betrayed: An Inside Look at Japanese Media Atrocities and Their Warnings to the West (Washington, D.C.: Regnery Publishing, 2004), p. 102.uu 
the truth, and even though some of us guessed Japan was losing the war, the government, through the military, hid the truth from everyone, so we didn't know the real story." Shunsaku Nanri, another reporter, recalls, "The newspapers were censored by the soldiers so much that the papers couldn't even write about the weather forecast." 


\section{Oita Men Troop to War}

\section{“Leaving My Hometown"}

The attack on Pearl Harbor brought an entirely new sense of urgency, anticipation, and optimism to the vast majority of the Japanese people. But while it was a dramatic turning point in their history, it was not the beginning of war for the people of Japan, for their military had been fighting since 1931 in China. Japanese initially viewed that fight not so much as a war, but as a necessary expansion required to enhance the economic and military viability of Japan under the guise of defending Asia against Western powers. Between the Manchurian Incident in 1931 and the Marco Polo Bridge Incident in 1937, there existed a prevailing sense that the Imperial Army was easily winning, or indeed had already won, control over much of China.

It was a time when there were fewer casualties among Japanese soldiers, thus fewer families were directly impacted and people had time to mourn those killed in a traditional and respectful manner. This would change dramatically after 1941, however. For example, Kou Takeda's brother was called to military service during the war with China, but eventually died during the Pacific War in the crucial battle that took place on the small island of Saipan in 1943. He recalls in adoring detail both the day his brother left to fight and the death that followed. His recall of those transitional events is a stark reminder of the conflicted emotions felt in the homes of those who did not return home.

My family lived in a small village outside Saiki. A river ran through our village and when young men left to join the military, their families and friends saw them off at the village boat dock. From there, they'd travel down the river to Saiki. They'd board the train at Saiki station and head to their military bases.

My brother Shinjiro Takeda was conscripted in 1939. He was well liked by the villagers for being handsome and kind-hearted. I was an elementary school student at the time and looked up to him. The night before he departed, family and friends gathered for a ceremony. Many brought sake and mochi, the customary drink and snack for such occasions. During the send-off, it was common practice for the mothers and wives of soldiers to drink sake while praying to the Guardian God for the soldier's safe return. Everyone encouraged my brother to do his best for the country and for the emperor, but the truth was we really just wanted our brother to 
come back home alive. During the ceremony, he was given the traditional "thousand-stitch" spiritual belt [senninbari] to ward off enemy bullets. He wrapped it around his waist dutifully. There is nothing as pitiful as a thousand-stitch belt, because it had no effect, and we all knew it. The women made them with sadness. ${ }^{1}$ My brother woke up early the next morning before daybreak and walked to the river at the edge of the village. About a hundred people showed up to send him off with war songs. But my brother requested no war songs. Instead, my fourteen-year-old sister Misako and my brother sang a traditional song entitled "Leaving My Hometown," as he walked to the boat dock. Everyone listened quietly. Four years later my brother was killed. He had become a sergeant. During that time, my sister worked at the naval military headquarters in Saiki, and she found out our brother's unit had been deployed to Saipan from Manchuria. By this time, we'd heard that Japanese casualties on Saipan ran quite high, so we were desperately worried, fearing the worst. A month later, officials from the Saiki town office came to the house to notify the family that my brother had been killed. They brought a small box holding what they said were his remains. I couldn't believe the bones of my brother could be in that box, so I opened it in front of my family. There was only a small wooden board with my brother's name on it. No one from the military ever came to pay respects to the family. My hobby was painting and I painted a picture of my parents and my brother in his military uniform. It hung in my parent's home and I've kept this painting until now. I think of my brother every day.

Now, more and more soldiers from our village perished in battles, and their remains were sent back in white boxes. Family members would go to Saiki station to retrieve them. They'd carry the boxes and walk through the village to their homes. During the war with China, dead soldiers and their families were treated with honor. Remains of the soldiers and their personal effects were returned to their families with honor and respect. Villagers would all go and offer condolences to the families and pay tribute to the fallen soldiers. After the war started with the United States, and as the number of deaths mounted, people became hardened. They no longer treated the dead soldiers and their family with special respect. Prior to the death of my brother, I had volunteered to enter the naval training school, for I'd been a firm believer in Japan's cause. With the death of my brother, I began questioning the implications of this war.

1 This belt, a wide, light-colored cloth stitched by the women close to the soldier to ward off enemy bullets, was presented to Japanese soldiers as they left for the war. 
The fighting in China seemed distant to most except those whose sons, brothers, and husbands were sent there to fight or work. Ichiro Hashimoto grew up in Oita City during this period. "In primary school, in the mid1930s, it was rather peaceful. They were fighting the war in China but it was peaceful inside Japan. So our education didn't change. The teachers would tell us that Japan is winning the war in China and would show us articles saying we took their tanks and weapons. But the textbooks themselves did not change. I noticed the difference in education only after I entered middle school, just after the war with America started."

Yoshio Ninomiya, born in $193^{2}$ in Oita City, also recalls his teachers' lectures about this period. "I was very young, but was taught that Japan must unite Asia, besides, Japan lacked resources like oil, so had to go into Asia to get those, also fighting America and England was necessary to ensure our survival." Hideo Sonoda, growing up in Oita City, remembers, "I was born in 1931 so my youth was a time of war. In the year I was born, Japan invaded Manchuria and colonized it. When I was entering elementary school in 1937, the greater war with China started. We had military education in the schools at that time and I drew pictures of the war during those days." Pulling a large colored picture from among his papers, Sonoda said, "I drew this when I was in the third grade. It's a picture of a plane attacking in China."

Yasuo Tanaka recalls his days as an elementary school student joining his classmates as they marched to the Oita City train station to send off the soldiers on their way to China. "We were marshaled together, waiving paper flags and joining in three 'banzais' as the soldiers walked down the street and boarded the train. Then, every first day of the month we walked 20 minutes from our school to Kasuga Shrine to pray for victory."

\section{A Buddhist Priest's Gift for Hitler}

By 1939 Japan was leaning ever closer to the Axis powers of Germany and Italy. In 1936 Germany and Japan had signed the Anti-Comintern Pact, an agreement directed against communist expansion and the Soviet Union in particular. In 1938 he announced recognition of Manchukuo, the Japanese-controlled puppet state in Manchuria. The media promoted this relationship and exhorted citizens to follow the examples of these new partners, as seen in the October 1938 edition of the extreme rightwing journal Bungei Shunju, a leading militarist voice, when it declared, "You might dream of such organizations as the Nazis and Fascists. Keep in mind, however, that it is the people, united and centered on Hitler and 
Mussolini, who are moving the world."2 Solidarity with its Axis partners was encouraged throughout Japan in newspaper stories and propaganda posters, some aimed at children. This was seen clearly in a popular image of the time showing elementary age students honoring Hitler, Mussolini, and Japanese prime minister Konoe.

One Oita resident made his personal contribution in a unique and, with some historical hindsight, shocking way. The authors discovered this while touring a Buddhist temple which stands just across the field from the old naval air base and kamikaze training facility in the town of Usa. Like most Buddhist temples in Japan, the role of priest has been handed down from father to son for hundreds of years. This temple's history is traced back over 500 years, and during the war served the soldiers as both a barracks and spiritual haven. The current priest, our host and guide, represents the $20^{\text {th }}$ generation in his family line.

When one visits the temple today, the first impression is of the beauty of the architecture and the impressive, centuries-old figure of the Buddha nestled inside the golden temple shrine. However, this temple has a more complex and recent history than shown in its ancient public forum, for in a separate narrow room unseen from the worship area but located directly behind the Buddha, a stunning revelation of Japanese enthusiasm for the war effort hits in full force. It is in this private room that the priest proudly introduced to us a long row of model Japanese battleships that his grandfather constructed so painstakingly during the war years and that survived the American bombing of Usa in the latter months of the war. They were each about three feet in length. Strolling down the row of ships, one is amazed by the volume and detail of the craftsmanship. Then, under glass at the center of this spectacle, appears a prominently displayed, well preserved, personally autographed photograph and letter of thanks to the priest from Adolf Hitler. So unexpected is this historic relic that it takes one's breath away. The current priest Soei Hirata, who also serves as head of the Usa historical society, told us the story behind the autographed photo. "My grandfather's hobby was the construction of these miniature replicas of Japanese battleships. It was his passion, and you can see that they were built painstakingly of metal, molded together from scratch. As both a spiritual and community leader, he decided to do his part to honor Japan's new ally and sent Adolf Hitler one of his replicas as a gift. This autographed photo and handwritten thank-you note was the response he received from Hitler's office. Ships were also sent to Benito 
Mussolini and Japan's prime minister, Konoe, but we don't have a response from them."

Our host offered no analysis or commentary on this, only a sense of pride in the efforts made by his grandfather in constructing the ships. For him, it seems, the Hitler photo was just a small piece of the story. For us, however, it was more and as we continued down the corridor reviewing other ships the unexpected encounter with Hitler dominated our tour. This celebration of Japan's alliance with the fascists of Europe, shown starkly through this one example, reminds us just how pervasive enthusiasm for war had become by the late 1930s and how seamlessly it merged into all facets of Japanese life, including Buddhist temples, which had historically promoted a tradition of a peaceful and reflective life. ${ }^{3}$

\section{Oita Soldiers}

Oita Prefecture sent soldiers to the army in large numbers during both the China War and the Pacific War. The contributions Oita made to the war effort beginning with the China War were not just the thousands of foot soldiers sent there to fight and die for the emperor, not the military bases scattered throughout the prefecture. This otherwise undistinguished corner of the island of Kyushu also produced a surprising number of military and government leaders to guide Japan during the war. One of the most important figures was Jiro Minami. This future general was born in 1874 in the fishing village of Hiji, situated between Beppu and Kitsuki. Minami graduated from the Imperial Army Academy in 1895, with a commission in the cavalry. He fought in the Russo-Japanese War and was later assigned to commanding roles in China and Korea during the first war with China in the 1920s. In 1927 Japan's Army General Staff prepared a report arguing that Chinese resistance to Japanese expansion in Manchuria was intensifying. Rather than continue trying to win over the Chinese to a superior power with a carrot-and-stick approach, more and more Japanese began to feel that Japan should force compliance by enhancing military rule. General Minami, soon to be appointed minister of the Japanese Army, agreed. He delivered a speech in August of that year warning of the danger of Chinese nationalism moving across Manchuria, arguing that it was not a temporary condition but a permanent one. Minami and his like-minded militant officers "found

3 The authors were provided a tour of the temple by the current priest, Soei Hirata, on March 12, 2012. 
their options reduced to the extremes of ignominious retreat or a violent push forward." ${ }^{4}$

After the war in China began anew in 1931, General Minami returned to China as head of the Kwantung Army and, at the same time, Japanese ambassador to the court of the puppet Manchurian emperor Puyi, who had been installed by the Japanese in an attempt to legitimize their incursion into China. At the same time, he served as governor general of Korea and, toward the end of the war, was appointed a member of the Diet and Privy Council to the emperor. ${ }^{5}$

During the war with China and then the Allies, Oita's contributions multiplied, as Minami was joined by other Oita natives who became, respectively, supreme leaders of the Imperial Army, Navy, and diplomatic corps. Each played a key role in deciding vital military and diplomatic strategies from the 1930s through the end of the war. It is also instructive to note that all three were uncompromising militarists who played pivotal roles in the enthusiastic beginnings of the war and its futile continuation even to the very end. Their roles will be explored more fully in later chapters, in discussing the final days of Imperial Japan.

Representing Oita on battlefields around China and the Pacific were men from the $47^{\text {th }}$ Oita Regiment, with soldiers recruited from throughout the prefecture. This unit first fought in China in 1933 to support Japan's goal of controlling northeast China in its entirety after the Manchurian Incident. Arriving on December 21, 1932, the $47^{\text {th }}$ engaged Chinese troops almost immediately after the New Year, moving toward Beijing. By April 10, according to an account by an Oita reporter well after the war, "the colors of the $47^{\text {th }}$ regiment were brilliant atop the Great Wall." By October of 1933 the Japanese Army, having gained control of more territory, signed a cease-fire and the $47^{\text {th }}$ "returned to Oita with glory." They would not return to China until 1937, when they took part in some of the bloodiest fighting in the war.

In the summer of 1937 men of the Oita $47^{\text {th }}$ received orders to mobilize for a new assignment in China with Colonel Masanori Hasegawa in command. At 5:15 p.m. on August 1, all members of the regiment gathered at the local Meiji Shrine, located in front of their barracks. They prayed for victory in

4 Yoshihisa Tak Matsusaka, The Making ofJapanese Manchuria, 1904-1932 (Cambridge, MA: Harvard University Press, 2001), p. 355.

5 C. Peter Chen, "Jiro Minami," World War II Database, http://ww2db.com/person_bio. php?person_id=362; “Minami, Jirō," Generals.dk, http://www.generals.dk/general/Minami/ Jir\% $5 \% 8 \mathrm{D} /$ Japan.html. After the war Minami was classified as a Class A war criminal, found guilty of the charges against him concerning aggression in China, and sentenced to life in prison. He was paroled in 1954 and died in 1955 . 
their upcoming fighting in China. They then walked through Oita City to the train station, where citizens had gathered to cheer them on. On August 3, they boarded a ship in Moji Port, stopping in Busan, Korea, on their way to setting up Camp Zhujaiwu, just south of Beijing. There they joined other troops in the $1^{\text {st }}$ and $2^{\text {nd }}$ armies in maintaining order and security in the area, awaiting battle orders.

Those orders came on August 31. The $47^{\text {th }}$, known also as the Hasegawa Regiment, received orders to move southwest and attack the city of Baoding. Before departing, Colonel Hasegawa was given fighting orders, along with the following instruction by his commander, Takagai. "Always cremate the war dead in a careful manner and send back the remains to the families of those soldiers. Also, your men are prohibited from raping and foraging." At this stage of the war, it was still feasible to send remains back to the families. As for the prohibition on raping and foraging, the growing intensity and horror of the war overtook such humane orders.

Over the next several weeks the $47^{\text {th }}$ fought their way through stiff Chinese resistance to the edge of Baoding. Following is the regimental history of the role the $47^{\text {th }}$ played in taking the city.

All were exhausted. In the silence of the night, Captain Torao Eshima was given the grave responsibility of creating a pathway to attack the enemy. He was ordered to send three soldiers on a suicide mission to breach the wall, opening up an entry point for the other soldiers. Eshima ordered $9^{\text {th }}$ captain Seitaro Abe to choose three men for this mission. They were Sergeant Takara Ishida, Lance Corporal Akiyoshi Goto, and Junior Technician Ashikari Kosaku. Each one only took a dagger and a hoe. They ran out from the trench and moved to the bottom of the castle wall. The enemy was alert and began tossing hand grenades at them. Fortunately, none of the grenades hit them. They decided to climb up the side of the wall step by step. Ishida went first, then Goto and Ashikare. Ishida lost his footing, and Goto took his place at the top. Ten minutes later all three reached the top. However, a small group of Chinese troops spotted them. Goto grabbed a gun with bayonet from the enemy and began shooting. Ishida and Ashikare followed, also capturing weapons. The three were now at the top of the castle, looking down the stairway entrance where about 100 Chinese soldiers attempted to come up to attack the suicide team. But they were blown away by the three men of the $47^{\text {th }}$ and ordered to surrender. The enemy didn't understand Japanese but they put down their weapons and surrendered. Goto took out a flag from his uniform and placed the Rising Sun over the north gate. The team opened the heavy 
door of the north gate and their comrades rushed in. It was 9:10 a.m. on September $24,1937 .^{6}$

This record is reminiscent of heroic war stories found throughout history, and some of the details have surely been embellished over the years. However, it is not disputable that the city of Baoding was taken, and that the members of the $47^{\text {th }}$ were at the forefront of the battle. For the $47^{\text {th }}$ and most other Japanese troops in China at this time, the brutality of the war was just beginning. After Baoding the Oita men pressed southward to join the battle for southern China, arriving just after the Japanese victory in Shanghai in late November.

As the $47^{\text {th }}$ pushed inland Shunsaku Nanri, the young Japanese boy living in Shanghai with his parents, remembers watching the buildup ofJapanese troops in the area.

I was born in Dalian, where my father ran a trading company. We moved to Shanghai, where I began the first grade in a Japanese school. There were a few Chinese and some Korean students in my school, but they were all Japanese nationals. We lived in the Japanese concession of the city, where there were elementary, middle, and high schools, as well as universities. My life was comfortable and safe. In the area where I lived were stationed about 2,000 Japanese sailors, so the Japanese in Shanghai were not worried for our safety. However, in the summer of 1937, during a school break, fighting broke out in the streets of Shanghai between the Chinese and Japanese armies. My family was advised to evacuate to a safer place. Our neighbor had a car and took us to the Japanese Club with others. We stayed there for about two weeks, away from the fighting. Then more and more Japanese troops came to the city, and the children were taken out of Shanghai. We boarded the ship Tsuwa Maru to Nagasaki. A few days later, we arrived at my mother's hometown of Beppu in Oita.

\section{On to Nanjing}

After the victory in Shanghai, the Oita $47^{\text {th }}$ Regiment was incorporated into the newly formed $10^{\text {th }}$ Army, led by General Heisuke Yanagawa, and then were attached to the $6^{\text {th }}$ Division, which was destined to lead the charge in

6 Takashi Hiramatsu, Battle History of Our Hometown Troops (鄉土部隊奮戰史) (Oita: Oita Godo Press, 1983), pp. 115 and 140. 
the coming Battle of Nanjing, the capital of Chiang Kai-shek's government. While Imperial Headquarters in Tokyo contemplated how best to follow up on the surprisingly difficult victory in Shanghai, on November 19 the $10^{\text {th }}$ Army's General Yanagawa, with fresh troops ready for action and without authorization from his commanders, brazenly ordered the men of the Oita $47^{\text {th }}$ and other regiments to follow and eradicate the Chinese Army fleeing Shanghai toward Nanjing. He wrote to his superiors, "The overall situation right now will not allow us to call off the Nanjing campaign. Also, I have a belief based upon my sixth sense that we can capture Nanjing easily by pursuing the enemy." This action caused consternation in Tokyo, as no attack on Nanjing had yet been announced. But it was too late to override the order and, like other important decisions in the war, high-spirited leadership on the ground overwhelmed central authority, and the troops forged ahead. On November 24, the General Staff issued the following instructions: "It is now no use to operate within the previously determined operation area in view of the situation of our troops and theirs [the Chinese]. In addition, a part of the CCAA [Central China Area Army] has already moved beyond the said area and is pursuing the enemy by capitalizing on its confusion. Accordingly, the operation restriction line ... will be abolished owing to circumstances beyond our control."

On November 30, the $47^{\text {th }}$ Regiment received orders to move quickly to Nanjing before the panic exhibited in Chiang Kai-shek's army after the fall of Shanghai could be repaired and the army reformed. Japanese bombing of Nanjing commenced, wreaking havoc throughout the city. Expecting little resistance and a quick victory, the officers ordered their men to take with them only essential fighting gear and medical supplies. Rations were not distributed prior to the attack, leaving soldiers to forage through the towns and villages encountered along the way. Uncontrolled looting, pillaging, and burning of villages followed in their wake. However, despite the chaos in the Chinese ranks, advancing was not as easy as anticipated, and several battles took place in which individual Chinese units regrouped and beat back the invaders, killing many Japanese soldiers.

On December 10, the $47^{\text {th }}$ participated in an all-out attack along the retreating Chinese Army's front by taking the heights protecting the southern gate of the city. Fighting was again surprisingly fierce, with many killed and wounded. But the Japanese eventually reached the heights overlooking Nanjing. Now they prepared to cross the city moat and take the city. On

7 Quoted in Masahiro Yamamoto, Nanking: Anatomy of an Atrocity (Westport, CT: Praeger, 200o), pp. 49-50. 
the following day, the $6^{\text {th }}$ Division concentrated artillery fire on the city's southwest gate while members of the $47^{\text {th }}$ were ordered to lead the charge into the city. The $3^{\text {rd }}$ Company of the $47^{\text {th }}$ began the attack on the night of December 11, crossing the moat on sampans and burning houses at the base of the wall to create a smokescreen. Six members of $3^{\text {rd }}$ Company then formed a suicide squad, climbing 20 meters up makeshift bamboo ladders to the top of the wall. One soldier fell into the moat while climbing, and four more were killed as they breached the top of the wall, but one young man named Nakatsuru climbed over the wall and into Nanjing. He was followed by members of other units. The Japanese $10^{\text {th }}$ Army, led by six men from Oita, had established a foothold in Nanjing that expanded quickly to Japanese occupation of the city. On December 17 , the $47^{\text {th }}$ participated in the formal entry ceremony of the army into Nanjing. ${ }^{8}$

\section{Nanjing Legacy and the Pride of Oita}

The success of the $47^{\text {th }}$ in these early battles in China instilled pride and confidence in the community and drew young men from Oita to join the unit when they reached the age of conscription. One such man was Shukichi Make, a young farmer who joined the $47^{\text {th }}$ in 1940 and rose to a command position before the end of the war. After the war he served as standard bearer of the $47^{\text {th's }}$ legacy, serving as the leading figure in organizing annual reunions and social services on behalf of former soldiers as they grew older. His memory of life with the Oita $47^{\text {th }}$ is replete with bravado and conviction in both the correctness of the war and the actions of the men under his command. In his mind, some 70 years after the battles had gone silent, it was the enemy who was cruel and deceitful, not his army.

When I was asked which regiment I wanted to join, I answered "the $47^{\text {th }}$." At the time I joined up, the $47^{\text {th }}$ was at the front line of war in China after occupying Nanjing. I wanted to join this unit for two reasons. First, this was the regiment of my hometown. Second, it was the strongest regiment in Japan. I wanted to be part of such a regiment. I was assigned to officer training. As an infantry soldier, I learned proper use of machine guns and

8 Yang Tianshi, "From Fightin at the Marco Polo Bridge, July 1937, to the Fall of Wuhan, October 1938," in The Battle for China: Essays on the Military History of the Sino-Japanese War of 1937-1945, ed. Mark Peattie, Edward J. Drea, and Hans van de Ven (Redwood City, CA: Stanford University Press, 2011), p. 178; and Hiramatsu, “Timeline of the Oita $47^{\text {th }}$ Regiment," pp. 203-204. 
cannons. Geometry was also compulsory for those of us learning how to use artillery. I also learned how to organize my men during a battle, how to order attacks, and how to focus on targets. In addition to these technical activities, I learned the Bushido Spirit - willingness to die to obtain glory and human fulfillment - from those that fought in the early $1930{ }^{9} .^{9} \mathrm{I}$ learned that leaders must work for the good of the country and be ready to die. I would run to the shrine located at the corner of the military academy every day after roll call to pray. I was trained in sword fighting, mountain climbing, kendo, and judo, as well as spiritual education. A story of three brave soldiers from our unit that we would follow into China was held up as a glorious example to the new soldiers. The three brave soldiers wrapped small bombs on their bodies, and together they charged at the enemy. These men were our role models, and we took pride in following their footsteps. One can say that members of the $47^{\text {th }}$ had the spirit of the kamikaze even before the Pacific War started. Yes, Bushido Spirit in Japan was there! ${ }^{10}$

Captain Make's family supported, indeed encouraged, his enthusiasm for the fight.

The night before I left for China, my family held a dinner for me. They encouraged me to fight bravely for Japan. My father, who had fought in a previous war in Siberia for Japan, told me that I should always remain calm and be ready to die, because I was Japanese. He also gave me his sword to remember him by. The women in my family had prepared a thousand-stitch belt for me to wear for protection against enemy fire. I kept it until the end of the war. Unfortunately, I was forced to hand it over to the enemy at the time of surrender. My mother tried to hide her teardrops. This was a typical family scene at the time.

Captain Make did not participate in the 1937 Nanjing attack, as he joined the military in 1940. However, he did serve with many of those who fought in Nanjing. He still insists that the actions of his fellow soldiers in the battle for Nanjing were appropriate in the rules of war, and the success in Nanjing played a part in his eagerness to join the $47^{\text {th }}$. With swelling pride, he argues,

9 Bushido involves not only fighting spirit and fighting skill, but also absolute loyalty to one's highest authority, personal honor, devotion to duty, and the willingness to die in battle or through an honorable suicide. Roger Davis and Osamu Ikeno, eds., The Japanese Mind (Tokyo: Tuttle Publishing, 2002), pp. 41-42.

10 In 2013 Captain Make, at 94 years old, still served as the leader of those few remaining members of the $47^{\text {th }}$ memorial organization. 
"The $47^{\text {th }}$ was one of the army's strongest regiments, fighting at the very front of the battle in Nanjing and many other battles thereafter. The reputation of our regiment was to fight, occupy, and then move ahead to the next battle. The $47^{\text {th }}$ was the first to arrive at the city gate of Nanjing and put up our flag." On the question of a massacre, Captain Make insists, "I don't believe there was a massacre." Any fault for excesses, he insists, falls to the Chinese military leaders who abandoned their troops, leaving the area in chaos and without leadership. Showing disdain for Chinese military leadership some 70 years after the war, he continued:

The Chinese military was undisciplined, unscrupulous, and cruel. On July 29, at the Battle of Tongzhou on the way to Nanjing, more than 200 of our soldiers were killed in the cruelest way. And at the Battle of Nanjing, the Chinese leaders totally abandoned their troops. In the chaos, the Chinese soldiers took off their military uniforms and mixed in with local citizens. This lack of order and discipline on the part of the Chinese and their cruelty were the cause of the confusion in Nanjing. You'd never see a Japanese officer run away from his responsibilities.

Emphasizing the orderliness exhibited by the $47^{\text {th }}$, Captain Make recalls proudly how he led his men.

We had strict orders to be disciplined. Depending on the cooperation from the residents in the city, rules were adjusted. For example, we were not allowed to drink the local water and had to check the feeding supplies for our horses to make sure they were not poisoned. Also, the men were not allowed to go out at night, because it might cause unintended problems with the local residents. In fact, we were always in a hurry to get to the next city and took no time to communicate with the local people. I personally never had to beat my men since they were well disciplined, though I know that happened in other regiments. For those in our unit who did break rules, we put them under detention. Also, after each battle, a small number of soldiers from the regiment were assigned to maintain peace and order in the towns we entered. These men would communicate with the leaders of the town or village, such as mayors or village heads. We did have sympathy for the enemy and wanted the local people to have peace again. Whenever we left a town, we'd distribute medical supplies and food to them.

This sanitized representation of Japanese intentions and actions from Captain Make fit well with the sentiment the Japanese government wanted to 
convey to the people of Japan during the war. This was especially prevalent in the training and indoctrination received by the soldiers prior to shipping off. Historians Haruko Taya Cook and Theodore F. Cook spell this out in the introduction to their book, Japan at War: An Oral History.

The Japanese people, and the army in particular, were ... steeped in a deep sense of superiority to other Asians. Japan was paternalistic in the best of times. It often presented itself as an older brother "leading the newly emerging members of the Asian family toward development." Such feelings, and a code of behavior that placed little value on the rights and privileges of an enemy population, left Japanese soldiers and civilians capable in wartime of committing shocking and widespread war crimes ... without a prevailing feeling that these were morally reprehensible. ${ }^{11}$

In fact, not only did the Japanese look down on the inferior Chinese, they were clearly racist. As one former solder remembers his own cruelty, "we were implanted ... with racism.... We disparaged all other races. If we didn't have a feeling of racial superiority, we couldn't have done it."12

Therefore, when the Chinese actually fought back with intensity and, at times, cruelty akin to that they had experienced from the invaders, Japanese soldiers were shocked and lashed out at what they considered ungrateful inferior people they had come to help. More than seven decades later, Captain Make still defends the actions of his fellow soldiers, who in his mind could not be faulted for their brutality. It is illogical, of course, but this is what Captain Make and his fellow soldiers were taught. They accepted these views unequivocally and the views forever imprinted in their psyche. For a "good soldier" like Captain Make to think otherwise would be to dismiss what he had, in turn, taught his men and to discredit his fallen comrades.

The events surrounding this attack and the occupation of Nanjing have been debated for decades, with many in Japan refusing to acknowledge the atrocities documented by eyewitness accounts from Chinese, foreign residents of Nanjing, and some former Japanese soldiers. Yet following the war some Japanese did acknowledge the excesses in Nanjing. Even in the home town of the Oita $47^{\text {th }}$, the Nanjing massacre is acknowledged:

11 Haruko Taya Cook and Theodore F. Cook, Japan at War: An Oral History (New York: The New Press, 1992), p. 25.

12 Tamura Yoshio, "Unit 731," quoted in ibid., p. 164. 
On August 1, the $47^{\text {th }}$ Oita Unit moved into China. They soon marched from Shanghai to the battle at Nanjing, helping raise the flag of the rising sun over that city. However, at this time, the Japanese troops lashed out against the Chinese in what is infamously known as the Rape of Nanjing. Not only were Chinese soldiers and civilians murdered, but there were many cases of looting, arson, violence, and rape. This incident is the perfect example of how war makes people mad, crazy. The number of afflicted persons is still debated, although the Chinese government believes it to be at least 300,000. At the time, information about the war was heavily censored and such acts as carried out by the Japanese soldiers in China were not reported at all. The Japanese public, unaware of how horrendously their troops were behaving, celebrated the multiple victories in Shanghai and Nanjing, shouting "Kougun banzai," or "Heaven praise the Imperial Army." The local newspapers called for the populace to participate in "flag parades by all citizens" and in Oita City 23,000 people gathered at Shirosaki Shrine to give praise for the continuous victories by lighting lanterns and carrying flags. $^{13}$

Most of the stories appearing in the Japanese press during and immediately following the attack on Nanjing were reported by a group of reporters and propagandists organized as the "Pen Corps." Reporting to the Japanese Army's military intelligence unit, they accompanied the soldiers into Nanjing and many other cities in China, describing the glorious victories of the Japanese Imperial Army. Oita newspapers, like those throughout the country, depended on these stories to educate the citizenry. ${ }^{14}$ The excitement over the victory in Nanjing was exhibited on the cinema screen as well as in print. In a 1938 film titled Nanking, soldiers returning to the front line after being wounded during the Battle of Nanjing were extolled as treasures of Japan. In cinemas across the country, the Japanese populace watched soldiers departing the military hospital, responding to "orders to return to duty where they will dance a jig of joy and others will envy them terribly." Then, as the soldiers march out of the hospital compound in Nanjing, they are joined by nurses and doctors in singing a military tune affirming their duty to fight and die rather than surrender: 
We punish evil

Our soldiers of loyal valor and giant strength

Travel far from their parents' country now with joyous shouts

With soulful bravery

We swear we will never come back alive if we lose $\mathrm{e}^{15}$

\section{Our Chinese Family Meets the $47^{\text {th }}$}

Among the Chinese, fear of Japanese atrocities spread with the movements of the Japanese Army. The following firsthand account of a refugee family shows this fear and desperation vividly. It is a personal story for the authors, arising from our research on the history of the $47^{\text {th }}$ Oita Regiment's activities in China. The authors were dismayed to find that in the days and weeks following the Japanese attacks in Nanjing and surrounding areas, the $47^{\text {th }}$ occupied the strategically important town of Wuhu. Wuhu is the home town of Ran Ying's mother and Ran Ying lived there as a young girl for several years during the 1950s. Her aunt, Ma Jifeng, shared memories with Ran Ying of her family's experience during the war. Over the years her memories were recorded by family members and they now provide a record of that time. The Battle of Nanjing and the ensuing occupation of Wuhu, then, had become much more intriguing to us, as we could follow the path of the $47^{\text {th }}$ and see the intersection with Ran Ying's family at this historically important juncture in the war. The following stories come from the memories of Ma Jifeng and her cousin Ma Jisen, Ran Ying's mother.

As the Japanese Army moved inland from Shanghai in the fall of 1937, families gathered what personal belongings they could carry and moved south by whatever means possible. One such group of refugees was the Ma family of Wuhu, a town soon to be occupied and administered by the Oita $47^{\text {th }}$ Regiment. The family patriarch, Ran Ying's great-grandfather, sent his two sons, two daughters, and their families, along with other relatives, to join the river of refugees escaping Japanese rule. The oldest was 45 , the youngest less than one year old. One daughter and one daughter-in-law were pregnant. They had no final destination in mind, only to escape the Japanese. Twenty-one members of the family evacuated to the south, with

15 From the 1938 Japanese documentary Nanking, http://wapwon.cc/video/Precious-film-ofsoon-after-the-Fall-of-Nanking36s/bpIQ7wQbKaE. It can also be found on YouTube: https:// www.youtube.com/watch?v=bpIQ7wQbKaE. No credits are available for this film, but it is clearly a wartime propaganda film distributed by the Japanese government. 
only the patriarch staying behind to watch the family home and restaurant business. The granddaughter of the patriarch, Ma Jifeng, who was fifteen years old at the time, remembers that as they evacuated Wuhu, and for much of the rest of the journey, the sky was red with fire, and filled with airplanes dropping bombs.

As we moved south, we found ourselves running away with the Kuomintang soldiers retreating from the Japanese who, we were told, were just behind us. We moved along with masses of panic-stricken refugees toward Changsha, which was about goo kilometers from Wuhu. When we reached Changsha everyone was exhausted, but even there we were told the Japanese were coming, so we forged ahead, going further south. We did not stop for eight days and nights until we arrived in Guangzhou, another 700 kilometers away. In the chaotic streets of the city, like everyone else, we searched for any safe haven we could find. We asked one of the Catholic Church priests for sanctuary, but were refused and ended up sleeping on the street. Guangzhou was not safe. My uncle was robbed of all his money by Kuomintang Army deserters, the family was cheated by local criminals, and businessmen took advantage of our plight. With all hopes dashed, my father led us back toward Changsha. During the return trip to Changsha my grandfather, two of my uncles, and one aunt died, and both my mother and my aunt had miscarriages. But we could not stop to let them rest, and they were forced to keep up with the family. In Changsha, we found that panic had grown deeper as the Japanese drew closer. With no place to turn to, my father decided that we should return home to Wuhu. Failing in our escape, exhausted, and missing home despite the fear of Japanese soldiers, we began the goo kilometer journey home. Exhaustion, starvation and sickness continued to take its toll along the way, as another uncle died, as did my one-year-old cousin. On January 5,1938 , those of us who were still alive, now only fourteen in numbers, returned home to Wuhu. ${ }^{16}$

During the months of this family's ordeal, the Oita $47^{\text {th }}$ moved on from Nanjing and established its regimental headquarters in the nearby town of Ningguo. In January, the Oita soldiers fought several battles and served as escorts for high-ranking officers inspecting the front, including newly appointed division commander Shiro Inaba. "When he came to inspect the $47^{\text {th }}$, his first battlefront visit, the regiment dispatched an escort force for him 
and they fought back against enemy snipers trying to hit the commander's vehicle. ${ }^{{ }^{17}}$ After the Nanjing operation, Japanese troops adopted a defensive posture, which demoralized the men. To counter this and keep morale high to maintain battle readiness, the officers sent them on limited engagements to 'intensify territorial control through 'punitive expeditions' and calling for frequent 'red alert drills."” ${ }^{18}$ The defensive posture was adopted as a response to the unexpectedly fierce resistance by Chinese troops between Shanghai and Nanjing. The historian of the Oita $47^{\text {th }}$ recounts:

During this time, hopes that the war would end soon were dashed, and this phase of the war was a deadlock. It looked to be a war of attrition. At the end of 1937, the Japanese deployment throughout China numbered sixteen divisions, with about 500,000 soldiers. As the battle lines were extended, exhaustion could be seen in the Japanese troops. Widely scattered Japanese fortifications were easily attacked by guerrilla forces, which forced our troops to engage in endless expeditions against them, exposing our men to much danger. As spring approached in March, Chinese guerrilla activity increased, and the $47^{\text {th }}$ Regiment deployed forces to various districts every day to undertake further punitive actions against the enemy. Without coordinated resistance by the guerrilla forces, our casualties were minimal. But when we pushed them, they pulled out and when we pulled out, they pushed us. It was quite impossible to fully expel them. On March 24, the regiment was redeployed to Wuhu where the $6^{\text {th }}$ Division was stationed. In Wuhu, a key river junction, we continued to fight local guerrillas, patrol the city, and carry out training drills every day. ${ }^{19}$

The populace was closely watched, since no Chinese were trusted, and guerrilla action continued apace. In Wuhu, however, the $47^{\text {th }}$ not only had to worry about the Chinese, but also some Americans. There in the north side of the city stood a hospital run by American Methodist missionaries atop a small hill. "As it was surrounded by difficult terrain, it was extremely well positioned to hide spies and anti-Japanese resistance fighters. Our soldiers approached the American director of the hospital, voicing their concerns. As a result, a patrol center was set up inside the hospital and an armed sentry posted outside the front door." ${ }^{{ }^{2} 0}$ 
For the most part, however, the Japanese did not interfere in the daily lives of most people in Wuhu, as policing and training in the area took most of their time. Ran Ying's mother, Ma Jisen, who survived the evacuation and return to Wuhu, remembers seeing Japanese soldiers patrolling the streets of Wuhu from the time of the family's return throughout most of the remaining years of the war. For the most part, it seemed, there was no interaction between the soldiers and the citizens. However, she remembers:

We often saw Japanese patrols in the streets, walking in single file and singing some Japanese song or other. The local residents had nothing to do with them on a daily basis. After I started school, there was a Japanese girl in my class, and she was fond of playing with me. Now that I think of it, her father must have been a businessman for her family lived in a flat near my home. I was young, so did not think too much and played with her as I did with my other friends. But, I know my family was worried about the older girls, so they were kept as far away as possible from the Japanese soldiers. During that period, my older cousin, Ma Jifeng, entered a Catholic School where she boarded. She would not come home for months at a stretch even though the school was right behind our home. When she finally came home, it was to be married off, almost immediately. This was because stories circulated that Japanese soldiers' going to local residents' homes searching for virgin girls. These intrusions happened in my friends' homes and they suffered at the hands of some Japanese soldiers.

\section{Securing Victory and Moving On}

As the Ma family returned to an occupied Wuhu, young Shunsaku Nanri, the boy who evacuated from China to Beppu in 1937, boarded a ship to return to his family in Shanghai, now under Japanese control.

In 1938, after the Japanese had taken control of Shanghai, I returned to be with my family there, leaving only at the end of the war in 1945. By then the atmosphere in Shanghai had changed, and we were warned in school to be cautious at all times. When I entered middle school, I participated in military training drills, marching and fighting. From the second year we were taught to use guns, although there was no bullet in the guns. The guns we carried in training were old-fashioned models. They were long and had been used during the Russo-Japanese War. Just before the end of the war, when I was in the third year, we would have 
live-fire exercises. My life was pretty much like students my age inside Japan. The content of our education was entirely Japanese. Apart from having Chinese servants and seeing Chinese walking on our streets, we lived in a completely Japanese community. In many ways, it was life as usual for the children. We even took vacation trips to other cities like Beijing and Lushan.

The $47^{\text {th }}$ Oita Regiment had not left Nanjing unbruised. Back in Oita, on February 13, 1938, a memorial service was held at the Oita military training facility for the 193 soldiers who had died in that campaign. There would be many more such services, as the Japanese forces - including the $47^{\text {th }}$ Oita unit in the middle of the fighting - began to sustain more and more casualties as they pushed the Chinese Army out of other cities, including Wuhan and Guangzhou. ${ }^{21}$ The stream of death notices, cremated ashes, and personal effects from dead sons and husbands, brothers and uncles grew over the years. Eventually orderly notification by an overwhelmed military ceased, leaving families with no option but to wait and see if their loved ones would ever come home.

By the late summer of 1938 the Oita $47^{\text {th }}$ departed Wuhu, moving to new battles in Guangji, Fenghuang Shan, and Hankou (current-day Wuhan). On September 15 Colonel Hasegawa handed over command to Colonel Tamio Iwasaki, recently arrived from Korea. The battle for Hankou was just entering a fierce stage, and the new commander inherited a weakened force. Demoralized from defensive strategies and suffering from malaria and poorly treated wounds and illnesses, he had much work to do. Finally, he succeeded in rallying his soldiers and on October 25 , the $47^{\text {th }}$ entered Hankou as part of the victorious $10^{\text {th }}$ Army. On November 3 , the emperor's birthday, a victory celebration was held in the city. From that time until the late summer of 1941 , the $47^{\text {th }}$ regained its strength and fought battle after battle in China, finally occupying the port city of Fuzhou between April 21 and September 3, 1941. From there it eventually moved to Taiwan, the Philippines, and Indonesia. ${ }^{22}$

21 Hoashi, p. 9.

22 Hiramatsu, “Timeline," pp. 244, 281, 292, 333,533; Tobe Ryoichi, "The Japanese Eleventh Army in Central China, 1938-1941," in The Battle for China: Essays on the Military History of the Sino-Japanese War of 1937-1945, ed. Mark Peattie, Edward J. Drea, and Hans van de Ven (Redwood City, CA: Stanford University Press, 2011), p. 214; “The Bataan Death March,” Asian-Americans \& Pacific Islanders in the United States Army, http://www.army.mil/asianpacificamericans/ history. 
While the Oita men marched across China, the pilots stationed at the naval air base in Saiki supported them by attacking Chinese cities from the air. Kou Takeda recalls:

I remember that the aircraft the navy used in the 1930s were the old biplanes. But we could see that the technology changed very quickly over ten years and biplanes were replaced by new types of single-wing aircraft. When the war started with China, the planes sent to attack China flew mostly from Saiki. Particularly the heavy bombing of Chongqing in 1938 was led by the Saiki Naval Air Force. When the planes left from Saiki, they joined with other aircraft at Omura Air Base in Nagasaki and flew on to China. They returned back to Saiki via Nagasaki. These flights were secret, and the local community never knew when they would leave or return. But we were very happy because we knew that Japan was winning the war with China.

Stopping for a moment to collect his thoughts, Mr. Takeda, who was over 80 years old in 2012 when he spoke at the local Peace Museum to commemorate the history of Saiki in World War II, shared an insight he had recently gained. "Only in the past few years, after talking with Chinese visitors to the Saiki Peace Museum, did I discover how much the Chinese people suffered because of the war with Japan, especially from the bombing by Saiki pilots. We, the perpetrators, never thought of this from their perspective." The horrors of these air attacks, aimed primarily against a civilian population, were kept secret from young Kou and all Japanese citizens for the duration of the war, and were rarely mentioned in the postwar era. In fact, the planes from Saiki took part in the massive bombing of Chongqing that started in May 1938 and continued even after the Pearl Harbor attack. In the initial attack, incendiary as well as conventional bombs were dropped, and in just two days more than 5,000 Chinese citizens died from the bombing. ${ }^{23}$

As the war in China intensified and Chinese resistance to the Japanese slowly gained in organization and strength due to the united front formed by the forces of Chiang Kai-Shek and Mao Zedong, battles raged across the country. The $47^{\text {th }}$ Oita Regiment, as we have seen, was in the thick of these battles. But not all soldiers from the regiment joined in the fighting; some stayed behind to train the new recruits. One trainer for the $47^{\text {th }}$ was Naomasa Kodama from Usuki, an ancient and historic Buddhist village with large statues carved into the hillside above the river south of Oita City. 
Like Captain Make, he joined the $47^{\text {th }}$ in 1940, having just turned 21, and eventually reached the rank of sergeant. Kodama's entry into the army was typical of many. Upon turning 20 and receiving his invitation to take the examinations to join the army, he reported for duty and passed all exams, both physical and written. The night before reporting for duty, Kodama's family and friends celebrated his acceptance into the $47^{\text {th }}$ at the local community center with eating and drinking, singing and toasting. He recalls:

On that evening many people wrote messages to me on a small Japanese flag. When my three brothers left for the army they received the same gift. I lost mine at the end of the war, but still have my brothers' flag. The women in the community also gave me a thousand-stitch belt to bring me good luck and protect me. I eventually took it to war with me, but I don't have it any more. The enemy burned it when the war ended for me in Indonesia.

Before going overseas to fight, Sergeant Kodama spent six months training in Oita, and then became a trainer himself.

Most in our unit were sent to war, yet somehow I was one of the few who stayed behind. At that time, the military classified soldiers into two types. One was active-duty professional soldiers (genekihei); the other was replacements, or backup soldiers (hojyuhei), who were needed to fill the ranks depleted by growing numbers of casualties. Oita had been designated as one of the training camps for the replacement soldiers who would serve up to two years and then return home. I remained in Oita for two years and was put in charge of training the newly conscripted soldiers. I took them to the training ground near Beppu, where we practiced throwing hand grenades from the top of Jumonjibaru Mountain. I taught them to shoot weapons and to sword fight in close combat. The training was very strict in Oita, in order to get them ready for what they would encounter in real combat. Everyone had to abide by military rules. If one person made a mistake, the whole group was punished. For example, if one soldier didn't bow properly, all in that unit were beaten, and then they had to stand at attention for a very long time while holding their rifles. I'm telling you, those rifles were heavy.

Finally, in 1942, Sergeant Kodama was relieved of his training responsibilities and sent overseas to join Captain Make and the rest of the $47^{\text {th }}$ just after it had left China. First he joined them in Taiwan, and then they went off to 
the Philippines for a short tour of duty. The $47^{\text {th }}$ then shipped off to Java for six months, finally stopping for the next three years in East Timor, where they stayed until the war ended.

I remember being surprised that the Philippines was more developed than I'd expected. They even had a tape recorder of some sort playing music in the cabaret those days. The people of Surabaya on Java were very nice to us, and when we moved to Timor we saw people walking around without shoes. I liked the native people there and spent time with them. There was little fighting on Timor, as the Portuguese soldiers had left. On Java I had my first experience of combat. We fought the Dutch, who were big and strong, but we Japanese won. I saw Dutch soldiers die, and Japanese soldiers die. One morning, I woke up to find 50 soldiers from my unit dead, just lying on the ground. Sometimes, local guerillas attacked us, mostly small incursions, nothing too fierce. In those battles I never felt any hatred toward the enemy; I didn't feel anything special really. It was just war. 


\section{The War Expands and the People Mobilize}

\section{Farmers and Fishermen}

As Oita Prefecture was still dependent on fishing, farming, and small enterprises during the war, most of the children at that time came from families of modest means. Young Kou Takeda's family lived as farmers in Saiki, as did Tafumi Yoshimura's family in Usa and Toyoki Goto's in Oita City. Yoshio Ninomiya helped his father in the local fish market, and Tadashi Ono's father owned a two-wheeled cart which he used to deliver rice to households after picking it up from a train or ship.

Sadayoshi Yutani, born in 1939, did not see his father until a year after the end of the war.

My father was an employee for the Japan National Rail Company. By the time I was born, he'd been sent off to work in Thailand, constructing its railway system. The company paid him and he sent money home to my grandparents and mother. We had a picture of him in the house that I bowed to every day, but I had no memory of him. He was just a common worker, not an engineer, and worked in different places in Southeast Asia. Have you seen the movie, Bridge over the River Kwai? You can see in the movie where he worked. After the war, he was imprisoned in Singapore. When he came home, I was already a primary school student.

Former Japanese prime minister Tomiichi Murayama was the son of a fisherman in Oita, and for the first few years of war his life changed little. Education for those like him, for example, was limited both before and during the war. "We did not have a high school in my district so we went to elementary school and then to higher elementary schools for two years. Those who wanted to continue their education would take placement tests for higher-level schools like the middle and high schools these days. But my family was poor, and I only completed the minimum required education, which was eight years. I started working but, at the same time, attended a night school, so that I could go to university later." During the war years Murayama and his six brothers all joined the military, three fighting in China. Murayama joined the army when he was 20 years old, the required 
age for enlisting during the war, though he never left Japan. Remarkably, all the brothers survived the war. He recalls:

Joining the military was not voluntary. It was a mandate. Very simple: when we turned 20, we joined up. There was a health check, and all those passing the health check were automatically enlisted. It was a direct command. No notification letter of any kind, you just went when you turned 20. ${ }^{1}$ There were people who had ailments or for some reason or other didn't go at the time. But they'd get drafted later if needed. This was part of the Japanese constitution that you would be conscripted for three years when you turned 20. If there was no war, you would be done in three years. But because we were at war, the country required you to stay longer. If you had done your military duties before the war started and you were recalled, that was when you'd receive a letter to reenlist with the military.

\section{Guarding the Emperor}

Isematsu Matsumoto, from a farming family in the village of Ooga, had similar experiences as a young man, but his fate took a different turn. Young Isematsu spent the war guarding the life of the emperor and his family in Tokyo. He explains:

In the 1930s, elementary schools offered a regular education, no military training. We studied subjects such as Japanese, ethics, math, and science. Of course, everyone knew of the war in China. At the time, Japan had done nothing wrong. China had attacked Japanese soldiers stationed in China, though it was called an "incident" and not a war. ${ }^{2}$ China even appealed to the League of Nations to support them, even though Japan had a right to be in China.

I remember once Mamoru Shigemitsu came to my school to speak to students about the war. That was a special event, because Mamoru

1 This statement conflicts that of many others who remembered receiving a letter around the time of their $20^{\text {th }}$ birthday telling them to report.

2 This was the Manchurian Incident of September, 1931, widely reported in Japan as aggression by China against Japan, despite the fact it took place within China against an occupying force. When referring to this event Chinese use the term “事变” while Japanese use “事件”. Both terms are translated into English as "incident" when, in fact, the Japanese term denotes a far smaller scale event. 
Shigemitsu was a well-known person from our area, who later became foreign minister of Japan. In April 1932, he'd been injured by a bomb in an assassination attempt in Shanghai. It must have been about six months after his injury. When he came to the school, we immediately stopped our work and greeted him by bowing. When I saw that he limped and had to walk with a cane, I thought, "Wow, men coming back from the war are so honorable."

Our military training started in middle school. At that time, middle school lasted three years. After that, some students went to vocational school. In rare cases, usually only one from my school, a few would go on to college preparation programs.

Because of the conscription system, my middle school set up a military preparation program, and I joined the program for five years. I studied academic subjects in the morning and trained in military drills in the afternoon. We learned how to fight in a battle, how to attack the enemy, and how to avoid being shot. We learned to use our environment to protect ourselves while approaching the enemy. We also learned how to carry out attacks at close range. We only had wooden guns for those exercises. Since I had to help support my family by working in the fields I went only two or three times a week. But I was considered a good candidate for the military at the time.

Students would usually graduate, and then enlist in the military when we turned 20. But some would join up before graduating from the program. I was one of those that joined the military in January, without graduating. Conscription had priority over completing one's education. I took an army placement test, made the highest marks from our school and entered the military before graduation. The placement test was administered by officers from the headquarters in Oita City. We underwent health checks and IQ tests. A month later, those of us who did well would find out about our assignments. The village mayors wrote letters of recommendation for us, but we had no choice in our assignment. The year was 1941.

I was assigned to the Konoeihei $2{ }^{\text {nd }}$ Unit, the Royal Guard. My job was to guard the emperor. There were only four of us chosen from Oita Prefecture, so this was a very high honor. I was excited and happy to get this appointment, but also awed by the responsibility, and I worried I wouldn't measure up. The four of us from Oita soon headed for Tokyo. Before being allowed inside the palace grounds, we spent a month learning how to stand at attention properly, behave properly, and march properly. We were not to write down any orders and instructions from our superior officers, because it could breach security. We had to memorize everything. Part of 
our training was in combat since we never knew when we'd be called to the front. So we were trained as soldiers as well as guards. It was not until September that I finally entered the palace to begin my duty of guarding the emperor. I spent the next four years at the palace, until the end of the war. I was lucky that I never had to fight at the front.

Isematsu Matsumoto's firsthand experience as an imperial guard fundamentally challenged his basic beliefs, especially in the divinity of the emperor, as he became one of the few people in Japan to actually see the emperor and interact with the family.

Up until the time I entered the palace, I believed that the emperor was a god and I was very curious what a god looked like. On Emperor Hirohito's birthday, April 29, 1942, a big festival was held inside the palace. The emperor came riding on a horse and carried a shield. That was the first time I saw him as a man. Later, when I was on duty standing guard at a building behind the palace, the emperor would often pass by to go study biology, which was his hobby. We were always notified of the exact time of his passing, so we had to stand with extra vigilance. We'd take our helmets off and bow extra low. It was during these times, seeing the emperor coming and going, that I fully realized he was a man, just like all of us, not a god. I was also deeply impressed by the beauty of the empress. The fact that she was actually a woman, not a goddess at all, struck me profoundly! Nevertheless, she was, indeed, a very beautiful human being.

The young Prince Akihito, who later became the emperor following the death of his father, was about ten at that time. In the winter, the royal family would go down to the southern palace because it was warmer. I often saw the boy running around playing tag down the beach. When I had a bit of time between my shifts, I'd go down to the beach to play hide-and-seek with him. We had always been taught that the emperor and his family were gods and goddesses, who never erred and always protected us. Now I knew that it was not so. I was not disappointed, though, to find out that he was not a god. Instead, I was actually pleased. ${ }^{3}$ 


\section{Empty Urns}

Community participation in local Buddhist ceremonies became commonplace in the early years of the war as more and more men died fighting overseas. Seiichi Kogo was a primary school student in Oita City in the mid-1930s, during Japan's military surge in China. When not in school, he spent his time working in the family sweetshop alongside his mother and grandmother, which had been in operation since the early days of Meiji, around the mid-186os. He recalls the feelings of a young boy being introduced to a country at war.

I had a close friend whose father went to China. He joined the army rather early in the war, joining the $47^{\text {th }}$ Oita Regiment with many of his friends and neighbors. He had received the "Red Letter" from the government instructing him to report to the army. The soldiers went off one by one, walking to the Oita train station for their departure. We didn't always go to the station but would see them off from our town. There wasn't any special ceremony when they left. I was still in elementary school, when his family was notified that he died soon after arriving in China. I attended a Buddhist ceremony when his remains were returned to the family. There was a military base near Ochiji Middle School. A tent was set up, and we lit incense for him and others who had been killed. They were all from the $47^{\text {th }}$ Oita Regiment. Each soldier's ashes was placed into its own urn and wrapped in white cloth. The urns were lined up next to each other on the podium. Many people attended the ceremony. We stood in silence and bowed. There was a monk who lit incense and sounded the gongs. For us kids it was a funny ceremony, and we were trying not to laugh. As I think about it now, I know that was very rude, but, at the time, we found the whole thing weird.

The war in China quickly evolved into one vast military effort that covered most of East Asia and the Pacific. Deaths multiplied as the fighting intensified and spread. One might enter the war fighting in China, but end the war on a ship, a beach, in a jungle, or a cave somewhere in the Pacific, killed by American bullets or flame throwers. Japanese soldiers expected to die, and were told, outright, they should die rather than lose the fight or be taken prisoner by the enemy. This was spelled out in Hideki Tojo's 1940 "Instructions for the Battlefield," written as a guide to "ideal soldierly conduct." It concluded, "Do not suffer the shame of being captured alive."4 
Soon, orderly return of dead combatants ceased and families grieved with no remains to intern. During her $100^{\text {th }}$ year, in 2012, Masako Ono sat down to reflect on her family's story during those years. "I attended a girls' school in my early years and remember playing in the mountains around Ajimu. My family owned a small shop, selling liquor and snacks. Our life was quite simple and peaceful. I got married and moved to Beppu during the war with China. I don't remember wartime life being difficult during the early years. It all changed, though, when my brother was inducted into the army. Then it became difficult. He died three or four years later on a ship that was attacked by Americans."

Masako's brother was a young officer in command of $5^{\circ}$ men. Masako's son Yosuo Ono continues the story:

All the men under his command were from Oita, and they trained right here prior to leaving for the war. My uncle went to war right at the beginning of combat in the Philippines. Japan had been winning when he arrived, but he was killed soon afterward. Before he left for the Philippines, he'd prepared himself to die. Like other soldiers, he had clipped his finger nails and a piece of his hair and put them in an envelope. This was for the family to remember him by. Just before going into battle, his personal belongings were stored away in case he was killed. The family never got his remains back. He was probably ripped to shreds. But because this was still early in the war and Japan still had some order, they did get some of his personal belongings and the envelope he had prepared. Not many men from Beppu had died up to that point. Our family even got paid handsomely from the government because of his sacrifice and service.

An army delegation came to the family to return my uncle's belongings. They brought a small box and said it held the bones of my uncle. I was young and curious. When no one was around, I opened it to see the bones, but there was only a piece of paper with his name on it. This is all we could take to the temple. There was a ceremony at the local temple where the residents came together and placed a stone marker in his memory and honor. Japanese tradition is that you visit the grave once a year. We still go to the temple even now, and the monks are there for us.

\section{Pure Spirit of the Saipan Children}

As the war intensified, young men not yet 20 years old, the legal age of conscription in Japan, began to volunteer for special service. One volunteer 
was Jiro Nakano of Beppu. As a high school student, he yearned to join the war and in October 1942, at the age of 16 , he passed the screening test to train as a telegraph operator in the Naval Youth Communication branch. Jiro left high school early and in April 1943 graduated from the Armory Engineer Training Center in Kokura, a city about 70 kilometers north of his home in Beppu. In May, he entered the Naval Communication School in Bofu, graduating in February 1944. He immediately left Japan with the $753^{\text {rd }}$ Naval Aviation Force bound for Indonesia. Due to his youth, Jiro was not forced to go overseas, but he requested to join the front lines as a volunteer. Knowing his mother feared losing her son, he did not discuss this with his family, nor did he inform them of the decision until just before he left. While his job was not to carry a weapon, but to maintain, transport, and operate the telegraph machine, he could not escape the horrors of war and remembers them vividly almost seven decades later.

I was dispatched to the $753^{\text {rd }}$ Naval Aviation Force at Kaohsiung Naval Base in Taiwan. When we left Kaohsiung on route to Indonesia, my ship was struck by a torpedo, so we had to anchor for three days in Cam Ranh Bay in Vietnam. After completing repairs, we set off for Singapore where we docked, boarded the Noshiro Maru and headed to Surabaya in Indonesia. After arriving in Surabaya, we changed to another ship. The Senko Maru was to take us to the island of Borneo. However, at 4:00 a.m. on the morning of March 24 the Senko Maru hit a mine as she entered Balikpapan Bay. At the moment of the explosion, I was on duty, corresponding by telegraph in the communication room. At the first blast, I was thrown to the floor, almost knocked unconscious. I fell hard on my tailbone, and I have suffered from that impact ever since. I crawled out to the deck of the ship, but water had rushed on board, and I was washed overboard. I saw many Indonesians, who had been sleeping on the top deck, slipping into the water at the same time. There were about 300 Indonesian workers and 200 Japanese soldiers on the ship. As most of the soldiers were sleeping in makeshift rooms on tatami mats below the deck, many of them drowned. I floated in the sea for most of that day, holding on to a pole that had been washed out of the ship's cargo. My skin became spongy, and I came very close to total exhaustion by the time I was picked up that evening. I was sent to a navy hospital in Indonesia, and then transferred to a hospital in Saipan by a navy escort ship..$^{5}$

5 Personal memoirs of Jiro Nakano (中野次郎) shared with the authors, written with his granddaughter when he was 79 years old, Beppu, Oita Prefecture, Japan. 
While recovering in Saipan, Jiro was visited by schoolchildren from the island. Saipan had been controlled by Japan since the end of World War I and thousands of Japanese lived on the island, with their families serving as government bureaucrats, educators, businessmen, sugarcane farmers and, of course, military personnel. In the spring of 1944 it was a quiet place except for Japanese military activity. For the wounded it served as peaceful respite from the hell of war, and for Jiro one memory from that time sticks out as one of his clearest of the war. It is a memory filled with mixed emotions, as he relates, "The schoolchildren from the Third National School on Saipan Island visited us in the hospital and taught me how to make origami cranes. I never forgot their visits." Leaving Saipan, Jiro boarded a ship bound for Tinian, "an island just like floating in the sea." He and his comrades did not know their final destination, but for a short while he had time to reflect on his life and his future. The near-death experience on the Senko Maru had awakened him to the realities of this war.

I went out of my barracks quietly, walking along a pathway in the middle of a cane field. I wanted to walk alone. Long leaves of sugarcane were making sounds on both sides of the path. I knew I was going to the front tomorrow, and death was standing right in front of me. I recalled my mother's face and regretted that I had volunteered without her consent and I couldn't be home to take care of her. Had I stayed home, her life would have been easier, and mine, too. I wiped my tears and said in my heart, "I'm sorry, mother. Please look after yourself and forgive me. I am going to die before you." A strong wind then began blowing from the sea, and I returned slowly back to the barracks. ${ }^{6}$

Soon Jiro moved with his unit to their Indonesian base. It was there that he heard what happened to those children after he left Saipan. "After we moved to Indonesia, the Battle of Saipan started. Because I was on the telegraph machine, I was the first to hear the news that after the American Army landed on the island, the children who taught me to make origami cranes killed themselves to protect the honor of their families, their emperor, and their country. They died hero's deaths."

Reflecting on these deaths seven decades after the war, the memories of the children remain fresh as he shares his tender feelings for the kindness shown him by these young people. At the same time, he still holds 
unqualified pride for what he calls the "honorable deaths and pure spirit of those children." He concludes simply, "I was deeply moved."

While Jiro may still respect the "honorable deaths" of children, such sentiment is unfathomable to others. Certainly this is true for the Americans witnessed those deaths first hand. It is difficult to reconcile, even after so many years, this divide between Japanese honor leading to the deaths of children and an American soldier's anguish at watching innocent deaths. Those who watched in horror as men, women, and children died by their own hands, or the hands of their parents, can never forget the scene. Lieutenant Colonel Justice M. Chambers of the $4^{\text {th }}$ Marine Division in Saipan remembers:

During the day as we moved along the cliffs and caves, we uncovered civilians all the time. The Jap soldiers would not surrender, and would not permit the civilians to surrender. I saw with my own eyes women, some carrying children, come out of the caves and start toward our lines. They'd be shot down by their own people. I watched any number of women carrying children come down to the cliffs that dropped into the ocean. They were very steep, very precipitous. The women would come down and throw the children into the ocean and jump in and commit suicide. I watched one group at a distance of perhaps 100 yards, about eight or ten civilian men, women and children get into a little huddle and blow themselves up.... It was a sad and terrible thing, and yet I presume quite consistent with the Japanese rules of Bushido. ${ }^{9}$

Lieutenant Frederic A. Stott of the same division witnessed similar self-destruction.

Interpreters were summoned, and they pleaded by amplifier for the civilians to come forward in surrender. No movement followed. The people drew closer together into a compact mass. It was still predominantly civilians, but several in uniform could be distinguished circling about in the throng and using the civilians for protection. As they huddled closer, sounds of a weird singing chant carried up to us. Suddenly a waving flag of the Rising Sun was unfurled. Movement grew more agitated; men

8 Ibid.

9 Quoted in Captain John C. Chapin, Breaching the Marianas: The Battle for Saipan, Washington, D.C.: Marine Corps Historical Center, 1994), pp. 35-36, http://ibiblio.org/hyperwar/USMC/ USMC-C-Saipan/index.html. 
started leaping into the sea, and the chanting gave way to startled cries and with them the popping sound of detonating grenades. It was the handful of soldiers, determined to prevent the surrender or escape of their kinfolk, who tossed the grenades into the milling throng of men, women, and children, and then dived into the sea from which escape was impossible. The exploding grenades cut the mob into patches of dead, dying, and wounded, and for the first time we actually saw water that ran with human blood. ${ }^{10}$

This eighteen-year-old boy from Beppu would see much more of war, and survive to tell his stories. We will revisit him later as Japan stands on its last legs and Jiro does his best to get home to his mother. 


\section{Invincible Japan}

\section{Moral Education}

Japanese education during the war years was founded on a philosophy of the divine nature of the emperor and the superiority and invincibility of the Japanese people and their military. The grounds for this heightened sense of patriotism and emperor worship by schoolchildren had been sown a decade before under the direction of the Ministry of Education and other agencies. Playing up the glory still celebrated from victory in the 1904-1905 Russo-Japanese War, the Department of the Imperial Household Ministry presented each school with a portrait of the emperor, the most important symbol of Japan's rising nationalism. In 1928 the government had produced a Statement Concerning the Guidance of Thought, which encouraged the "promotion of education" and the "cultivation of the concept of the kokutai." As the title states, it was a plan to guide the thoughts of young people in the direction of unquestioned loyalty to the emperor at all times. The Ministry of Education directed that all schools and universities throughout the country implement this new campaign to guide young people in a unified direction. By the 1930s a cult of worship for the emperor was in full force, giving the military leaders in Japan an unquestioned mechanism to transform Japan into a militaristic nation with expansive dreams. ${ }^{2}$

By the mid-1930s, just prior to the 1937 surge in attacks across China, the Ministry of Education infused public school instruction with ancient mythology mixing Shinto and emperor worship with warnings to stay clear of Western ideas. At the same time, Emperor Hirohito was promoted as the broad protector of Asia writ large, thus setting the stage for young people to dismiss "Asian little brothers" and "Anglo-Saxon enemies" as inferior. ${ }^{3}$

Schoolchildren were taught these values through various means, including the use of a large pictorial book describing the mythical history of Japan's royal family, lessons in moral education and the glorification of national heroes. The exhortations and historical accounts promoted in the book are accompanied by pictures drawn in graphic detail. Titled Pictorial

1 Bix, p. 201. The concept of kokutai stipulated the unquestioned spiritual and exclusive loyalty to the Royal Family over all Japan.

2 Francis Pike, Empires at War: A Short History of Modern Asia since World War II (London: I.

B. Tauris, 2010), p. 85; Bix, pp. 201-203.

3 Ibid. 
Imperial Rescript on Education, this book was published in $193^{\circ}$ just as Japan was set to invade Manchuria. The book is replete with paintings of the emperors' ancestors transforming themselves from deities in heaven to deities on earth. Glorious fighting men are shown protecting the nation in previous wars, and famous cultural heroes of Japan exhort the young people to protect and die for Japan.

One who remembers the importance of this book is Nobuo Kawamura. Kawamura was born in 1921 and served as a teacher in Oita City at the time of the attack on Pearl Harbor. He remembers, "This was a kind of moral education, a foundation for how children were supposed to think. Students between the ages of 6 and 20 were to hear words from this book every day, and to learn them by heart. All students had to study hard to recite the text, and if I as a teacher did not force the daily reciting, then I would be punished. I memorized the complete text, and every morning I would recite it first, and then have the students repeat after me. Even today I can recite this book. The Pictorial Imperial Rescript on Education was distributed throughout the country, but only 2,0oo copies were printed with color pictures. I was one of the 2,00o teachers honored to receive the color edition and have it still today."

In 1937 the Ministry of Education further promoted this view, producing a pamphlet titled The Fundamentals of the National Polity. Distributed in schools throughout the country, and eventually selling over two million copies, this document informed students of the ideological and spiritual position of the emperor and his appointees in creating a moral and benevolent society. Students should understand the "bright, pure, and selfless heart" of the Japanese and appreciate that Japanese people were superior to all others in the world. The family was to be honored and ancestors worshiped. Finally, Japanese should remember that their country had twice been saved from foreign invasion by the "divine winds" (kamikaze), proving once and for all that Japan was protected and indestructible so long as it followed its "living god," the emperor. ${ }^{4}$

Listening to those who were of school age during the war, it is striking to hear the optimism they shared, and the amazement they felt when later, like Yoshio, they discovered much of what they had been told was a lie. This optimism arose from two main factors, both of which controlled people's access to information. First, the media played its part through presenting carefully scripted newspaper stories and radio reports. Second, schools throughout the country never wavered in building enthusiastic support 
for the war. In the initial six months of the Pacific War, newspapers were full of victories around Asia, and rightly so. Only days after Pearl Harbor the British warships Prince of Wales and Repulse were sunk in Malayan waters. People were thrilled with conquests in Malaya, the Philippines, Singapore, and the Dutch East Indies. When British-controlled Singapore fell on February 15, 1942, celebrations around the country went on for three days. Hidekatsu Nakano, though only a child living in a village outside the city of Oita, remembers these celebrations well. "I was in the second grade when the Pacific War started and my grandfather was mayor of our village, which had about 3,00o people. I remember that the fall of Singapore was a great victory for us. The villagers gathered together with the students and teachers to celebrate this victory at the school, which served as our community center."

The Oita newspapers heralded the victory, with headlines declaring, "Singapore Finally Falls," and "Brilliant! Imperial Japanese Army's Achievement among the Century's Greatest." Pictures of the British officers handing over Singapore to the Japanese Army were captioned, "British Army Surrenders, Admitting Defeat." The stories that followed under the headlines reported that "the enemy in Singapore agreed to unconditional surrender at 7:50 p.m. on February $15^{\text {th }}$. The commander of the British-Malay Army met Lt. General Yamashita at the Ford Factory in Bukit Timah at 7:00 p.m. and they signed the unconditional surrender and cease-fire to begin at 10:00 p.m. on the $15^{\text {th }}$. 5

The claim that Japan was invincible was proving true, and the enthusiasm was contagious. The day of victory in Singapore saw Oita residents gather in the streets to watch an impressive celebratory display of naval air power as military planes flew over much of Japan, including their city. As reported on February 17 by the local press under the headline, "Naval Air Force Congratulated on Excellent Achievement,"

Kure Naval District will conduct a special flyover with 156 aircraft from the Kure Naval District Air Force to congratulate the Naval Air Force for its excellent achievement in this sacred ceremony in Singapore. Commanding is Major General Kira Shunichi. Each unit leaves its base and marshals above the Seto Inland Sea. After that, the units will pass over Hiroshima at 2 p.m. They will conduct special maneuvers under the supervision of Admiral Toyoda, Chief of the Kure Naval District. The overflight covers Kyushu, Shikoku, Chugoku, and Kansai for a distance 
is more than 1,00o kilometers. They will finish the flyover at 4 p.m. and each unit will return to base. Our Oita unit will take part in this flyover. Journalists in the navy division of each newspaper will attend to cover the story of this event to uplift the morale of the Japanese nation. ${ }^{6}$

The local newspapers encouraged the entire populace to mark this victory in a manner that could only occur in Japan, when they announced that the city would distribute $360 \mathrm{cc}$ of sake to each household, asking the citizens to gather in their neighborhood associations to ceremonially toast the Japanese military with a kampai. ${ }^{7}$

\section{Hiding the Truth}

As the war dragged on, victories proved harder to come by, while defeats and stalemates began to wear down the military. The censors prohibited candid reporting, and the media efforts to stimulate support for the war veered ever further from the truth. Censorship intensified and people rarely discovered any outright admission of defeat for the duration of the war. While early stories reported genuine victories, later stories hid the truth to keep up public morale. Victories were exalted and defeats turned into victories. These stories, coupled with the "moral" education taught in the schools, kept young people's focus on victory and sacrifice unchanged, therefore ensured unquestioned support for the war.

Only a few dared to question the war propaganda, with Admiral Yamamoto the most important among them. Yamamoto was "too shrewd and too experienced" to believe all the claims made by the High Command and Imperial Headquarters. Even in the flush days following Pearl Harbor, he criticized the overzealous statements made by his own naval spokesmen in Tokyo about the ease with which Japan was winning the war. ${ }^{8}$ But his words were drowned out by the thunderous propaganda. The Battle of Midway on June 5-7, 1942, is but one example.

Coming early in the war, this ambitious naval operation was designed to eliminate much of the U.S. Pacific Fleet and to capture the U.S. base headquartered on the small atoll of Midway, located at the very northern tip of the Hawaiian island chain. The plan was then to move once again

7 Ibid.

8 Hoyt, pp. 28 and 33 . 
on Hawaii, further demoralizing the Americans and forcing a negotiated peace on Japan's terms. But the Japanese were the ones to be surprised, for, unknown to them, their military codes had been broken and American ships rushed to intercept the Imperial Navy as it approached Midway. The attack proved costly to Japan in losses of both ships and personnel. The outcome emboldened the American military and citizenry, raising morale to its highest point since Pearl Harbor. Admiral Matome Ugaki, watching the battle from his flagship and recognizing the seriousness of the defeat, records in his dairy on the evening of June 5,1942 , "Thus the distressing day of 5 June came to an end. Don't let another day like this come to us during the course of this war! Let this day be the only one of the greatest failure of my life!" On June 7 he continues, "During the two months of April and May, planning and preparations were made with great effort with this day as a goal. Before this target day came, however, the tables had turned entirely and we are now forced to do our utmost to cope with the worst case. This should be kept in mind as a lesson showing that war is not predictable." 9

Most naval commanders knew of the serious losses and possible consequences, but the people heard not a word about it. In fact, Japan had lost four aircraft carriers, a heavy cruiser, and 3,00o men in the Battle of Midway. This included 121 top pilots, who would be almost impossible to replace in a short time. Midway Island was damaged by bombing, but never taken, and it continued to play a crucial role as a forward American base for the remainder of the war. Even in Tokyo the significance of the loss was kept closely guarded, as navy officials refused to entrust the government with an accurate accounting, worried that such honesty would damage morale and endanger military intelligence in the future. Only the emperor was informed of the total picture, and he decided not to share this even with his army officials, who proceeded to make plans based on inaccurate information. Across government and military lines, the censors worked diligently to promote the Battle of Midway as if it were no setback at all. Most were led to believe that "the Combined Fleet was healthy and secure."10

Needless to say, the common citizen in Oita Prefecture remained ignorant of this defeat, and looking at the newspaper accounts of those days we can see why they kept such optimism. The Oita Godo Press of June 11 summed up the Battle of Midway with, "The Imperial Japanese navy launched blistering sharp attacks against Midway, the base of the enemy in mid-ocean. At the same time, it trapped the U.S. fleet in this area and pounded it, wreaking 
enormous damage on maritime and air forces. During the Midway battle two U.S. aircraft carriers were sunk, one Enterprise class and one Hornet class, and 120 aircraft were shot down. Damage to our forces included one aircraft carrier lost and one damaged. A cruiser was damaged and 35 aircraft are missing. ${ }^{, 11}$ Misinformation filled this account of Midway and, after this story appeared on June 11, Midway was rarely if ever mentioned again in the local press. For the citizens of Oita, the war remained a glorious venture and the military remained invincible.

\section{Military Education}

The overwhelming imperial and nationalist education presented each day in school mirrored the newspaper accounts, took hold, and stayed current in most people's minds throughout the war no matter how dire the circumstances, even toward the end. This education was presented through stories, lectures, physical training, and rote memorization. And in many cases it was beaten into them. Quite literally.

Toyoki Goto, only a third grader when Pearl Harbor was attacked, remembers:

It seems strange in today's world, but at the time we didn't really think of it as "military" education. It was just an education, nothing strange or abnormal about it. We were all in the same boat so it wasn't like we ever wanted to speak out against our government. We simply didn't think anything of it. Back then, there was only one perspective, and we had no idea there were other perspectives. If anything, if someone spoke out against what the country was doing, they would be ostracized, like a black sheep.

Just like children all over the world, these primary school students romanticized war and acted it out in the fields, shores, and villages near their homes. As young primary school students, they had little or no military training in the early years, but that did not mean there was no military education. Toyoki Goto remembers, "We were constantly taught about the war in school, especially about the victories of the Japanese military and faith in the emperor. We'd rush to play war games after school. The older kids would teach us about different ranks and responsibilities in the army so we 
would arbitrarily decide what we wanted to be. Then we'd split up between friend and foe. We didn't choose other nations as enemies to fight against; it was just good against evil. ${ }^{{ }^{12}}$ However, a more specific enemy was targeted by Yonosuke Yanase and his friends. "After class we would play at sword fighting [chanbara]. We would divide up the kids; some of us were Japanese and others either Americans or Chinese. We'd always make an enemy."

Textbooks even for the youngest children of elementary age used every opportunity to raise the level of patriotism. The texts teaching Japanese language and grammar to second-year students used simple poems and stories to accomplish this, as shown in these two poems written about experiences in occupied China:

Colors

Colors colors, his Imperial Majesty gives us the precious colors

The precious colors show the sign of our army

Colors colors we will protect our nation with the words of his Imperial

Majesty

In our heart

Colors with the soul of our army

Colors colors we will go to the enemy territory prepared to die for his

Imperial Majesty

Our army's colors

Colors colors our army always wins

Our army's honored colors

\section{On the Asia Train}

The Asia train is running in Manchuria, arriving in Shihei

One of the soldiers talks to me with a smile

I can see the flag of Manshukoku in the farm over there

Soldiers staying in Shinkyo

When I bow to them, they come to shake my hand. ${ }^{13}$

Even the fourth-grade Japanese language text conveys a clear message to students that they have a part to play in the war. This text, meant to be

12 The author, and interviewer, is American and it is highly likely that in some cases the exact truth is shaded to save embarrassment on both sides and in fact the enemy in these games was the United States or its allies.

13 Japanese Ministry of Education, Elementary School Japanese Grade 2 (初等科國語 二) (Tokyo: Japan Book Co., 1942), pp. 76-78. 
recited by both teacher and students, focuses on the experiences of a young girl as her family hosts soldiers who are training to fight overseas:

\section{Maneuvers}

1 Just as I thought I heard the pitter-patter of a horse, a brave horse soldier rode right by us. Because the military was passing through our town tonight, my mother took me to the dining hall. Eventually, a deep rumbling preceded the arrival of tanks. I was surprised how the earth shook as the townspeople came out to see. Foot soldiers came marching toward us. My mother prepared to serve tea to the soldiers. Many combat vehicles arrived, but the roar of the vehicles was too loud and the townspeople got frightened and ran away. The soldiers arrived and their captain said, "Take a 20 minute rest." War veterans, women, and young ladies helped serve the tea. The soldiers are very dirty, covered with dust and sweat, and are keeping us very busy bringing us their canteens for more tea. We worked till around 11 p.m.

2 The morning had not yet come when we heard the sound of a gunshot to the north. Teachers took us girls to watch their maneuvers and performance. The glorious airplanes arrived with a very loud roar. When we heard the sounds of cannon I wanted to go see them as fast as I could. We watched the maneuvers but could not tell where they were shooting the guns. We could only see the foot soldiers running with sticks and straw on their bodies. After a while soldiers appeared carrying the emperor's flag and marched by. The leader of the marksmen appeared, watching the tactical operation without wearing any thick coat. When we saw that we had no words to say, but tears came to our eyes.

Not all reading lessons focused on the brave soldiers, as the young people were being prepared for more practical contributions to the war effort, as seen in the following fourth-grade lesson. The narrator sounds eerily like Mr. Rogers from the American children's television show a half century later:

\section{Making the Cannons}

I wonder how they make all the cannons that shoot down airplanes, tank cannons that shoot through thick metal, and the battlefield cannons pulled by horses. Have you ever wondered the same? Visiting a manufacturer of these large cannons, you can see a big powerful machine that melts the metal into liquid under a white flame. This molten metal is then poured into molds that don't really look like cannons. After being removed from the mold, the large metal slab is then heated bright red 
again. A large hammer that shakes the whole foundry then pounds the cannons into the right shape. Like making mochi with the mortar and pestle, the big machines shape the ball of metal. This way the metal is strengthened over and over, but that is not all they do. After stretching this metal to look like a rod, they put it into a tall furnace to heat up again. The rod waits patiently in the furnace. Eventually, the furnace doors are opened and the hot rod rolls slowly out. As soon as it came out of the furnace, the rod is dropped into a pool of oil 10 meters deep. For an instant, the black surface of the oil turns red as the rod sinks deeper into the black pit of oil. Beating, heating, and chilling the metal, make it stronger. If these were not done, the cannon would be blown apart by the powerful gunpowder; it would not be strong enough to be a proper canon. In the same way our hearts grow stronger by withstanding the cold of winter and the heat of summer. The strengthened barrel is then raised by a machine and shaved into a perfect cylinder. After shaving off the dark, rough edges of the barrel, we finally see the white shimmer of the cannon. Beside this machine stands a high school graduate, a 23-year-old young man who carefully covers the cannon with oil to smooth the process. As the exterior of the barrel becomes smooth and the cannon reaches the right length and diameter, the inside shaft that holds the cannon ball is carved out. A sharp blade is set on the tip of the cannon barrel as it starts to spin, slowly grinding its way into the barrel. The blade digs a hole; one centimeter, two centimeters deep, slowly but surely into the hardened barrel. One little mistake would make the entire cannon useless so the engineer keeps a close eye on the machine to make sure.... Once this process is completed, the antiaircraft barrels are mounted on a metal base and pointed toward the skies, getting ready to shoot down airplanes in an instant. Rubber wheels are attached to the smaller cannons that shoot enemy tanks no matter how fast the tanks run. ${ }^{14}$

As the war eventually reached Japan via American bombers, the texts were updated to stress the importance of children staying vigilant by watching the skies for enemy planes. The following poems for fourth graders reflect this,

\section{Poem 1}

On a rainy day and windy night,

On summer days when the noon sun burns,

On mornings when winter winds pierce our bones - no matter when, 
I am standing here, always.

As winter passes,

The bright spring comes,

The water-colored skies

Are blanked by scattered clouds floating by.

This big sky,

Stretching for all of eternity,

Our bodies become our eyes,

Our bodies become our ears,

As we stare up at the sky suspiciously.

Even now, somewhere in the sky

We can hear the tiniest of buzzing,

We can see the swarm of planes like bugs,

We warn everyone and we run around like a tornado.

Poem 2

The time, the direction,

Friend or foe,

How many of what model?

The altitude, the direction.

I run to the phone and shout.

"Number Five, Aoyama Watch Station,

Thirty Seven Minutes, North,

Enemy, Mid-Size, Thirty,

Three Thousand, South-East." ${ }^{15}$

\section{Learning to Kill, Preparing to Die}

Tetsuo Tsukuda was a ten-year-old boy living in Beppu in 1941. Classes, he remembers, did not change much at the beginning, but soon military trainers arrived in his school and began military education. "It started with a morning bow. Upon arriving at the school each morning, we'd first bow and pray to the photo of the emperor at the front gate. Then, all the children would assemble in the school grounds, face the direction of Tokyo, and bow again to the emperor's residence in his palace. After that we'd march and sing military songs, boys and girls together. Talking to each other during 
this time was strictly forbidden. Only after the marching exercise would we go to our classrooms to begin class."

Yonosuke Yanase remembers the daily routine of his life during those war years.

A typical day during this time started around six or seven in the morning. For breakfast we'd have ichiryu-sai, which was some rice with a small side dish. As farmers, we had our own rice field, which produced 600 kilograms of rice a year, so my family had enough to eat. We usually had miso soup as the side dish or pickled cucumbers. But I remember they were not very good. Sometimes, we'd have an extra dish of a small piece of fish. My mother fixed my bento lunch, and I'd carry it to school. I'd walk to school with friends either wearing straw sandals or barefoot. We didn't have shoes. Class started at eight. Each morning, we'd pass the picture of the emperor before we entered the school. We'd bow to the picture; in fact, we wouldn't actually see the picture, because it was placed in a shrine. But we knew it was there and we knew what he looked like because his picture was all over the place. We just weren't allowed to open the shrine. The school officials would open it four or five times a year, for example on the emperor's birthday. The principal would walk around carrying the picture. Inside the shrine there was a kyoiku-chokugo along with his picture. This was a message from the emperor on education. The principal would take these documents out of the shrine and read the creed of education out loud. The students were not allowed to look up, and we had to keep our heads bowed. This lasted about five minutes. It was so boring that we'd whisper to each other. We had our heads bowed so long our noses would start to run. Children caught cold or got sick easily then due to lack of food. So you could hear kids sniffing all through the crowd of about 100 students. We didn't have handkerchiefs, so we'd just sniff. While standing at attention, the teachers would get mad at us if we made noise or got out of line. They would yell or beat us. Some teachers would hit us as we stood there. We were really scared so we usually tried to behave ourselves. Once in a while, someone would fall over because they were sick or weak.

Those special days when the emperor's picture was shown were holidays. We'd be let out of school after the ceremony. We'd even get presents from the school, like sweets or tangerines.

A common theme heard from the memories of these people is the role of teacher as disciplinarian, especially the subtle differences found among 
the teachers in this role. Yonosuke Yanase describes both sides of one of his teachers in primary school:

When I was a fifth grader, there were 40 boys in my class. One day, Yabuchi Sensei [Teacher Yabuchi] asked, "When you eat rice, who do you give praise to?" Everyone's answer was either "the emperor" or "the soldiers." I was the only one that said, "the rice." Everyone laughed out loud. They were all thinking of the military, the emperor, or the country, but I thought we should thank the rice for giving us nourishment. This was because my dad always told me that the rice was more important than anything, even our lives. While everyone was laughing, Yabuchi Sensei stayed silent. Then, he said, "That is another way of putting it. That's gijin-hou." Gijin-hou is giving life to inanimate objects. I remember him standing up for me. I thought he was a great teacher for having an open mind. At the time most Japanese teachers would not have been so kind. But, of course, he was also a strict teacher and taught us that we should to join the military and give our lives for the emperor, but that was expected. ${ }^{16}$

Takafumi Yoshimura remembers that after the war began with the "AngloSaxons," military education became stronger and the students' determination to join in the war grew. There were also new requirements to contribute to the war effort.

When we turned ten years old we would go to the houses of those who had children in the army and help them with their farming. At school we had military drills, but because we were elementary school students we did not have real guns, so it was like we boys "played" war. We also learned military-style marching. Soon graduates of our elementary school who had joined the army came to talk with us. They told us that we should prepare to be soldiers soon. They became our role models; we thought they led exciting lives and we all wanted to be soldiers. This was aimed at the boys. We never talked with the girls, who were in different classes, but I believe the girls did sewing. All this was led by the teachers. We were

16 One reason the teacher would have found this explanation acceptable is that Shinto, the national religion of the time identified with Japan's militarism, is based on a belief in the spiritual nature of animals and inanimate objects. Thus while the response from Yonosuke was unexpected, an enlightened teacher disposed to humane treatment of students would have found this defensible in the context of Japanese culture. 
taught how to hold a gun, how to walk, and how to act like a soldier. Our guns were just sticks and in primary school our training was done just by teachers, no real military men.

Ichiro Hashimoto's education in Oita City changed dramatically after the bombing of Pearl Harbor.

In middle school, we had military education and training. Three or four military training officers trained a group of $5^{0}$. In physical education class we would do both regular and military exercises. We wore military uniforms to school. We would wrap our leggings and wear hats like the military. We had wooden guns. We'd run $10 \mathrm{~km}$ and then do body-building exercises. We'd sword fight with stick swords. We'd played with stick swords before, in primary school. But now, stick swords were no longer toys. We also made human-sized wooden dolls to ram with the bayonets attached to our wooden guns. At my school, we didn't draw faces or anything on the figures we bayoneted, but I know that in some schools students drew the faces of Roosevelt, Churchill, and Stalin on them. These were not child's play; they were real exercises. We all hoped that by demonstrating our dedication we'd be able to attend one of the military schools set up for middle school students all over Japan. My goal was to attend a naval school and become a pilot.

When Tetsuo Tsukuda became a junior high student in the mid-1940s he went to school to prepare for a soldier's life. "We were taught that American and British soldiers were devils, or monsters. Even in elementary school, our teachers talked about the war every day and encouraged us to be soldiers when we grew up. No one ever said anything against the war, and if any teacher was suspected of saying something negative he would be fired, then arrested by the military police." After school, the students would sometimes go to Beppu Park, which was adjacent to a military base. "At the gate to the park, there stood large posters with the figures of Roosevelt and Churchill. When we went there, we'd be given balls to throw at their hearts. If we hit the heart we'd get candies as rewards. ${ }^{17}$

Tadashi Ono was nine years old in 1941. He remembers how quickly things changed in school after December of that year: 
Before the Pacific War, there were books and notebooks but after the war started, there were few books or notebooks. Teachers and the military trainer drilled the idea into our brains that it was our duty to die in the war. They told us that we must be brave and that the desire to die for the emperor and the country was an honorable thing to behold. The girls would spend their time sewing the thousand-stitch good luck belts in sessions organized by schools and families.

\section{The Beatings}

Corporal punishment was widely used in schools, and memories of teachers and older students beating the younger students are fresh and vivid over sixty years later. While common before the Pacific War, school beatings grew in ferocity as the war continued. There was no time for softness. Corporal punishment was a regular feature of military training in school, mimicking actual practice in the Japanese Army, where soldiers were regularly beaten by their officers.

Tadashi Ono remembers that despite the tender ages of students, they were strictly disciplined. "Even if we didn't really do anything bad, maybe just a bit rowdy, we'd be hit or made to stand for long periods in front of the class. Once my teacher hit me and pushed me so hard that he broke my arm." Displaying his crooked arm during our interview, this man of nearly 9o years old said, "To this day I can't raise it fully." When Tadashi went home that day, he lied about how he broke his arm. "We could never tell our parents about these beatings, because they'd surely support the teachers. In the eyes of the parents, teachers could do no wrong."

Toru Takaya was a fifth grader when he began military training. Like most of the young boys, he hoped to impress his military trainers and his teachers so he could later be commissioned as an officer.

In middle school, we'd do things like improve our balance by going inside a large bamboo ball while trying to remain standing. During the training, teachers were very strict. If one student did something wrong, it would always be a collective mistake. We'd all be made to stand in front of the class, and the teacher would beat us with a stick. This would happen even if we were supposed to stand, and one student was sitting, or if we should be sitting when one student remained standing. Sometimes we didn't even know why we were being punished, but the teacher was always right. 
An especially rough episode stands out. One day after our morning meeting on the school grounds, we went into our classrooms. Five or six of us were playing in the room when the teacher arrived. Then the teacher took us back outside, told us to strip down to our underwear, and ordered us to sit in a tub of cold water. This was during the winter, and it was snowing, so of course we were freezing. He went back into the classroom, leaving us out there in the cold. When the teacher returned, he checked the water temperature and declared that it was not cold enough. He proceeded to add more cold water to the tub where we were sitting. If we complained of the cold, he'd get angrier. We sat in the cold water for about 30 minutes. Another time, also during the winter, all the boys were disciplined for one boy's mistake. Again, we stripped down to our underwear. The teacher made us run several kilometers. This was better than sitting in the water, though. At least running warmed us up. I could never tell my parents about these punishments, because they would have scolded me for not following the instructions of the teacher.

For Masaaki Yano, the elementary school student from Canada who had moved with his family to Japan, the memories of harsh treatment by military advisors in his school are as vivid today as they were during the war. As the nephew of Admiral Hori and still seen as an immigrant by some, he was watched intently by students and teachers to gauge his response to this training.

Just after the Pearl Harbor attack, we experienced "extreme militarism." I was fifteen at the time. In our school in Kitsuki, the military instructors and regular school teachers sat separately in the teachers' room. The military instructors were arrogant and mean, regularly hitting or slapping us to instill military fighting spirit into the students. I was physically rather weak, but I put up with this, and didn't say anything to my parents. Although, my parents must have known this was happening. Between the military instructors and regular teachers and students there was an unbridgeable gap. I was terrified of military instructors.

The reasons for punishing students differed between the military instructors and school teachers. Under the military instructors, the students had to show perfect harmony in group activities. A group of 50 in one class would be divided into four or five smaller units. We would mimic war by running outside in formation, using real guns without bullets. We made straw men to attack with bayonets; they represented the enemy. If one student made a move that was not in unison with the rest of the 
group, we'd all be beaten. Our school teachers were not so brutal; they'd hit only an individual student when he didn't understand the content of the subject we were studying.

Education and expectations for girls were noticeably different from that of the boys. When the war began, Yukie Matsumoto was a middle school student in the village of Ooga, just outside the fishing town of Hiji. As a student in the village school, her education was hardly disrupted during most of the war, except for the introduction of training in self-defense. "My school was small, so the boys and girls studied together. We didn't have military training with weapons, but all the girls were trained to fight off the enemy with large bamboo sticks. We were trained in this not as warriors to fight as a group, but as individuals who might be attacked by enemy forces. The boys were trained by military men, but we were just trained by our own teachers." Unlike the boys, who practiced the art of war as aggressors with rifles, bayonets, and hand grenades, the girls trained in defensive tactics to resist foreign rapists and killers. The beatings experienced by the boys were not replicated with the girls, though the education and training prepared them equally for death.

When asked what the discipline was like for her and her friends who broke rules or made the teacher angry, Nobuko Eto, from the small seaside town of Tsukumi, remembers little in the way of training in self-defense and no physical discipline of the girls in her class, only kind teachers, "There were girls who made fun of those less fortunate, like those with some type of deformity or those like me, who were very short. But the teachers just used to reason with them to correct their ways."

From the viewpoint of teachers, strict discipline of students was inevitable. The times called for it, principals and military instructors required it, and students grew to expect it. Even if at some personal level individual teachers found this distasteful, harsh behavior went on unabated throughout the war years. One former teacher who experienced this was Nobuo Kawamura. Discussing his life as a teacher and, later, reluctant military officer, Kawamura explains that while he taught students to die for the emperor, he and his family had little eagerness to join or support the war, even if it meant breaking the law.

During the war, my father would disappear for half the year. I didn't know where he was or what he was doing. I only knew that when he came home he would put 100 yen bills in the family cash box. Back in those days, you wouldn't earn even 100 yen in a year. I didn't find out until he died what he 
was actually doing to earn this money. I don't want to tarnish my father's name, but during those months away, he was arranging for young men to run away to a small island near Okinawa to hide from military service.

In other words, his father was smuggling conscripted and active soldiers to a safe haven away from the war. From all appearances this was purely a financial scheme, with no political motivation. While this was far from a common practice, it shows that not all Japanese felt total loyalty to the emperor and the war effort, but managed to use the war for their own self-interest. In the end, though the son could not fully escape his duty. Kawamura continues:

In the 1930s, I was a middle school student in Oita City. Everything in school was focused on the emperor. I studied fine arts. In 1943, on October 21, my education was terminated and most of us joined the work force to support the war effort. The fine arts students, however, were distrusted by the military so we were allowed to go to university and get a certificate to teach. After receiving the teaching certificate, I was sent to a school in the countryside near Beppu. At that time it was safer to have a teaching certificate, as you wouldn't be drafted by the military. My father knew the dangers of military life and guided me in this direction. So he was pleased that I became a teacher. But I wanted to help out in the war effort in some way, even as a teacher. While a university student, I prepared myself for this and took judo, kendo, and other martial arts classes. When I left university I took these skills and taught them to the children in my village school. I taught them to kill. We had to be strict with our students in order to prepare them for military life. Children were called the "emperor's children" and the objectives of Japanese education, at the time, were that the kids should put the nation first and think of the emperor as their father. Some people were opposed to this type of education, but I could not ease up on the students. Girls and boys were split into two schools, and I was in the boys' school, where I was especially strict with my students. Because I had avoided the army, I knew I had to go overboard to demonstrate my loyalty. My students were the emperor's children, I told myself, and their lives belonged to the emperor. Government mandates made it clear that the children were the subjects of the nation and the emperor, and this was not to be questioned. This was why I was so strict.

The term "strict" as used in wartime Japan indicates extreme punishment meted out to children who were considered undisciplined, so Mr. 
Kawamura's admission he was "especially" strict makes it clear that he did not shirk from using harsh physical punishment to get his students' attention. His years of avoiding the military and remaining a strict teacher came to an abrupt end later in the war.

In 1944, March 10 was National Army Day. On this day, all the students at school split into groups and practiced marching drills around the school yard. Around 9 o'clock, during the morning assembly, I was directing boys to do combat drills, when my father suddenly showed up at the school. Of course, there were no phones in our village, and I didn't know he was coming. I was summoned to the principal's office, where my father told me that I was drafted into the military. It came as a shock since I had been exempted from military service. I was informed that the government had just announced that all men between 19 and 45 were to report for the military, and all previous exemptions were no longer valid. My father could not save me, as he had others. I was 22 at the time, still young, but now went from teaching war to children with sticks to being a soldier with real a weapon.

The unspoken desire to avoid military service, while far from the norm, was not uncommon among even among some students approaching the conscription age of 20. "Desperate to avoid serving, many men faked physical disabilities and illnesses. Some drank a large bottle of soy sauce before a physical in hopes of inducing temporary liver or heart failure. Others lost a massive amount of weight through the use of laxatives." ${ }^{18}$ Yet as the war effort became more desperate and legal means of avoiding duty more difficult to obtain, men who thought they were safe saw the maximum age limit for conscription increase and health deferments decrease. Some tried alternative service, or at least service that would keep them off the battlefields.

High school student Mamoru Hirano, for instance, avoided battle by entering a special training program to maintain aircraft that participated in kamikaze attacks over Okinawa. He recalls:

I attended an agricultural high school in Usa during the first few years of the war. I was supposed to graduate in March 1944, but my family knew that the military didn't have enough fighters for the war, especially in China, and that I would be drafted immediately after graduating in 
February. About that time, the government called for volunteers for a special military training program that would take eighteen months to complete. I didn't know what the special program entailed; only that it had something to do with being trained as an engineer for airplane maintenance. It did not matter much what I was to do, as I saw it as an opportunity to avoid being drafted, assigned to a combat unit, and sent overseas to fight. I also thought it would allow me to graduate at the regular time in March. But because the war was going badly, in fact many of us were forced to graduate in December in order to speed up the supply of new soldiers. On top of that, the eighteen-month special program was in fact completed in ten months. In December 1944, I was assigned to the $101^{\text {st }}$ Squadron, which was part of the air corps attached to the Tokkotai (kamikaze), ${ }^{19}$ so I ended up in the military, after all. However, this delaying tactic probably did save my life, as I never had to go to the front.

\section{Creeping War Weariness}

Despite government pronouncements about the success of Japan's military actions, life in Oita rapidly deteriorated. One local Oita historian recounts:

As the Asia Pacific War escalated the lack of military fighting power and lack of labor forces sufficient to keep up with the demands of the war became evident. War weariness spread. Productive men disappeared into war, leaving the elderly and women to harvest the fields, to fish, and to work in factories. The government declared that all citizens should contribute, and further strengthened the "Student Labor Contribution" by ordering young teenagers to work in factories. By mid-1944, it was already accepted that an invasion of Japan was imminent. The military, with civilian cooperation and assistance, began preparing coastal defenses throughout Oita Prefecture in anticipation of American landings. An elaborate system of pill boxes was constructed and trenches were dug along the hillsides overlooking the coast, while new caves were dug out of the mountains to house factories, evacuations, and command control centers. $^{20}$

19 Japanese rarely use the word kamikaze when speaking of this special force, rather they use the term Tokkotai, which is translated as "Special Attack Force."

20 Hoashi, pp. 55-56. 
Military conscription intensified further. Students who were initially protected from the draft were now pressured to enlist. Student laborers, both male and female, entered the workforce. Because of labor shortages, appeals were even issued in Korea and China for volunteers to work in Japan. However, the term "volunteer" was used loosely in many cases, when people working in their fields were forced into ships and trucks and transported to Kyushu and other parts of Japan. ${ }^{21}$

While the men prepared for fighting, some young women volunteered to do what they could for the country. Nobuko Eto led a wartime life worthy of her own biography.

I was born in January 1928 in Tsukumi City. I was a tiny baby. At the time, the only heating device we had was fire stoves and charcoal pots. My mother would tuck me in her kimono or lay me next to a heated stove to keep me warm. That was how I survived the first winter of my life. In March 1944, I graduated from an all-girls school and decided that the best way to help my country was to become a nurse, so I enrolled in nursing school. My class had 30 students, with 20 in nursing and 10 in midwifery. There was a clear line, by long tradition, between the older, experienced nurses and midwives and those of us just entering nursing school. For example, when we were activated to join the military medical teams, our elders would hit us if we made mistakes. Furthermore, the first-year nursing students not only had to be more diligent in carrying out our duties, but also take on additional tasks, putting in extra hours of work while others were resting or sleeping. We'd have to sneak out of our dorm rooms at 5:30 in the morning without waking anyone to clean the hospital or sterilize equipment.

In the fall of 1944, the war took a turn for the worse, and supplies began to run short. In class we would be thrifty; by using the backs of old pharmacy prescriptions to take notes on and by tying bamboo sticks to pencils that were otherwise too short to hold.

Our dormitory was situated on the same street as the $47^{\text {th }}$ Regiment's army base and we saw soldiers come and go all the time. During those days the newspapers reminded the residents every single day that all must pull together and never give up the fight until Japan won.

The turning point for me was when an air raid killed some students at Ueno Middle School in March 1945. For the next three months, air raids

21 Ibid.; and Colonel Hiromichi Yahara, The Battle for Okinawa (New York: John Wiley and Sons, 1995), p. 236. 
only intensified. We dug a shelter under the floors of the hospital, but it was musty and full of mosquitoes. There was no food and water in the shelter, either. We all avoided going into the shelter as much as we could. During my second year, six of us took on the responsibilities as messengers. Before each air raid, we'd receive information directly from the military and we'd run around to inform everyone in the hospital and dormitory of coming attacks. "Air Raid Warning," "Air Raid Imminent," we'd shout over the megaphone. ${ }^{22}$

Even in far off Shanghai, where Japanese troops protected thousands of its citizens engaged in commerce, education, and government administration, an awareness of coming defeat took hold. Individual families had to make decisions about staying in a country that might be regained by the Chinese, though they dared not utter those words. Shunsaku Nanri recall, "Even though I never saw any fighting in Shanghai, and even though my parents didn't say it, I think they knew Japan was losing and Shanghai would not be safe. So my sisters and I were evacuated back to Japan in December 1944. Many Japanese were leaving at that time, so there were no sad feelings of leaving friends. I came to Beppu to live with my mother's family. The only thing we worried about going back to Japan was the rumor that there was little food to eat, as there was never any shortage of food in Shanghai." Young Shunsaku returned to a prefecture soon to be heavily bombed and strafed by American airplanes. He found the educational practices of the teachers the same as in his Japanese school in Shanghai, but his time in the classroom did not last long. He was quickly mobilized as a student worker assigned to a powder mill factory south of Oita City, and worked there until the end of the war. 


\section{$6 \quad$ Fire from the Sky}

\section{Prime Targets}

A sign that the war was finally reaching the homes, fields, schools, and factories of Oita Prefecture came on January 1, 1945, though most people did not notice it at the time. On that day, the first American B-29 bomber flew high over the city of Oita. Only a handful of residents noticed the plane, as it left nothing but a streak of white mist in its path. No alarms went off and the newspapers did not report it the next day. An American reconnaissance plane, surveying the land below and mapping future bombing sites, came and went quietly. But for those who understood what they were seeing, a new and unsettling feeling emerged for the first time since the war began.

Oita Prefecture was a hot spot of Japanese military activity in early 1945 , and ripe for attack. The $5^{\text {th }}$ Naval Air Fleet Command Center was located in Oita City. Additionally, the $12^{\text {th }}$ Air Group headquartered at the Oita Naval Air Base and by early 1945 served as home base for hundreds of naval fighter planes, including kamikaze. It was located next to the Oita River and was surrounded by a rural area called East Oita Village. In close proximity to this village had recently been constructed the $12^{\text {th }}$ Naval Air Factory. This facility operated as a repair, maintenance, and manufacture center for the planes based in Oita and Saiki, as well as the nearby naval air commands in Fukuoka and Miyazaki. In neighboring Tsurusaki, Sumitomo Chemical manufactured bombs while Nakashima Industry produced bullets and airplane parts. The factories that made up this munitions and repair industrial center controlled the supply of weapons for bases throughout the region. Most of these manufacturers were controlled tightly by the military and employed forced labor who worked alongside regular employees, including many women.

As the war expanded and more men went off to fight, the lack of a sustainable labor force undermined the military's frantic need to repel the Allies as they moved closer to Japan. Earlier in the war, the government had decreed that all citizens should contribute to the war effort and instituted the "Student Labor Contribution" aimed at young students. By 1944 the use of student labor was well established. Under this plan, students attending middle school were assigned to factories such as the ones in Oita City. As part of their educational curriculum, students would leave their classrooms to work as unpaid laborers. By the end of 1944, there were 12,000 workers in these factories, including 8,00o student laborers. Oita Middle 
School supplied 1,200 student workers. Other schools sending young people to these facilities included Oita Shougyou, Oita Men's Shihan (currently Oita University's Department of Education), Shihan Girls' School, Daiichi Girls' High School, Daini Girls' High School, Tsurusaki Kougyou, Beppu Middle School, Beppu Girls' High School, Hiji Girls' High School, Usuki Middle School, and Takeda Girls' High School. All schools were located in Oita Prefecture, but half were located some distance from the city of Oita. The need was so great that sacrificing education for the war effort went unquestioned by the country's military leaders and was embraced by teachers and their students.

By early 1945 the number of student workers grew to 16,0oo boys and girls. As Oita was still a rather sparsely populated rural and fishing prefecture, 945 students from outside Oita were sent there to work. As fewer and fewer adult men were left in the country to work in the factories, the responsibilities of the children expanded. The jobs they undertook included:

- acquisition of materials;

- airplane manufacturing, body maintenance and repair;

- airplane engine manufacturing and repair;

- weapons manufacturing;

- Ration Control Department;

- accounting;

- medical support;

- communications. ${ }^{1}$

Seiichi Kogo was a middle school student in 1945 when he left the classroom to work in the military factory.

I entered Oita Middle School, but didn't study much. The students were practically brainwashed to die for our country and to make other sacrifices. We were treated like soldiers and trained as though we were in the military. By the end of my third year in middle school, we were forced to work in factories due to severe labor shortages. Basically, our school education was finished at that point. My teacher divided students up into groups. I was assigned to the parts shop in the $12^{\text {th }}$ Oita Naval Factory, making parts for the airplanes. There was an air base right next to the factory, and some students were sent to work on the base. Others were sent to torpedo factories, engine factories, and so forth. We'd go straight to the factories every morning to meet up with the teacher and 
start working. There were students from many different schools at each factory. In school the boys and girls were always separated, but at the factories we worked side by side.

I was happy then, because I'd always enjoyed science classes and loved making things with my hands, especially technical things. The specialized military technicians in the factory were my role models. I really wanted to become a technician, not just because I loved science. I also knew that technicians wouldn't have to go to war. I didn't want to join the military at all.

We worked every day, and my job was to repair the Ichi-shiki planes. ${ }^{2}$ The planes would come in damaged during air raids or even during training exercises. We would make parts of the planes by reading the blueprints of the planes and the parts. Back then, machines were not widely available, we often made airplane parts manually. Occasionally, we had a machine that was useful, but overall we just looked at the blueprints and made the parts by hand, a piece at a time. We worked in groups of ten under the direction of a qualified engineer. There were lots of groups; each was instructed to make a specific part.

Hideo Sonoda had a special assignment. He prepared the innovative kamikaze Oka ("cherry blossom") aircraft for their one-way mission. Oka were small, one-man kamikaze guided missiles attached to a larger plane, which were dropped close to the intended target

I worked on the Oka. Metal was scarce, so we made what we could with wood and thin plywood, including the dashboard, measuring tools and what have you. The parts came in all shapes and sizes. After my section cut the pieces and shaped them into appropriate sizes, another section of workers would assemble them according to the planes' blueprints. We had no machines, so we worked the material by hand, cutting, shaping and so on. On the back of the Oka, there were these antennas. Rocket switches were used to propel the Oka plane when they were released from their mother planes. The Oka flew very low, so that they could ram into the American warships. When an Oka plane was ready for a mission, the bombs and chemicals were placed under the belly of the plane.

Like many other youths from surrounding towns and villages, Kitsuki's Masaaki Yano was assigned to work in the military industries located 30 
kilometers away in Oita City, where he was housed in a dormitory for student workers.

I went to Oita City to work in a factory making gunpowder when I was eighteen. The students were assigned different jobs in making the gunpowder. Mine dealt with nitric acid. The recipes for mixing gunpowder were top secret, so the complex mixture was done by experts. The students were watched closely by soldiers at every moment, so we had to stay conscientious and work diligently. In the end, this was a good thing. Because we were extra vigilant in following the strict rules and procedures, we didn't have any accidents at our factory.

As the young students began transitioning into the military factories around Oita, American bombers expanded their targets beyond Tokyo, Nagoya, and other major cities. In mid-March, 1945, General Curtis LeMay gained approval to attack cities around the island of Kyushu. This decision was based on the American plan to invade the Japanese territory of Okinawa as the first step to invading Japan proper. Kyushu, which would be the next stop after Okinawa, was home to multiple naval and army air bases and could easily launch attacks on U.S. troops from those southern vantage points. LeMay's list of priority targets named airfields and factories in the cities of Kanoya, Miyasaki, Tachiarai, Nittagahara, Omura, Oita, and Saiki. ${ }^{3}$ Usa was added to this list as the raids began. The bombings would continue off and on for the rest of the war.

On March 18, a week after the Tokyo Air Raids began, the first bomb was dropped in Oita City, in anticipation of the April 1 scheduled attack on Okinawa. The goal was to attack as many bases in Kyushu as possible, destroying not only enemy planes but also enemy bases and factories, thus severing supply lines for fuel and ammunition. ${ }^{4}$

There was some indication that this attack was imminent, for a Japanese reconnaissance plane had sighted enemy ships headed for Okinawa on March 14 and reported this to the $5^{\text {th }}$ Naval Air Fleet commanded by Admiral Matome Ugaki, who ordered an attack on the American fleet. All planes in Oita, Usa, and other bases around Kyushu were ordered down to southern Kyushu for these attacks. At 3 a.m. on March 18, planes began leaving their 
bases to fly south and attack the American ships. It proved a great loss for Japan, because over 200 Japanese planes never made it home. The Americans reported not losing a single ship. Then, as Oita citizens began their day, the Americans took off for targets on Kyushu, with Grumman F6F Hellcat fighter planes and Curtiss SB2C Helldiver bombers targeting several Oita locations.

The Oita air command expected the Americans to strike early in the morning, while it was still dark, so the maintenance and pilot crews scrambled to get their remaining planes out of the hangers and scattered around the base. At 8:30 in the morning, about 30 American planes appeared above Beppu Bay just seconds from Oita. The attacking Grumman fighters and Curtiss bombers approached rapidly and began bombing the hangers and dispersed planes on the ground. The bombs kept falling, causing ear-piercing explosions one after another. The Americans then started attacking the whole base. Those on the ground recalled the eerie, screeching noise of rapid fire. The Grummans were targeting the planes the Japanese had moved from the buildings. Bomb after bomb exploded, leaving planes destroyed and black smoke rising everywhere. Not only had the Americans shot up the buildings, they heavily damaged the runways as well. Because the Japanese had warning of the attack and reacted quickly to get the planes out of the buildings, only five planes were destroyed in the massive raid, with minimal casualties. It was, as one local historian remarked, the best outcome of the worst scenario. ${ }^{5}$

Although the military escaped major damage that day, those students working in military factories were caught unprepared, for the Americans turned their guns on the areas around the base, including the $12^{\text {th }}$ Naval Air Factory. It was just the first of many bombings and strafing they would endure. Hideo Sonoda, barely a teenager at this time, recalls:

On March 18, 1945, the first air raid struck Oita City, only a week after I had begun working in a military factory. The Grummans attacked the factory where I was working. My friends and I ran outside when the attacks started. On the way to the bomb shelters, the planes flew right at us and started shooting, so we jumped into the river to hide. The bullets were flying just above our heads. The planes flew so close; we could see the pilots' faces. Then bombs exploded around us. I was fourteen and terrified. That was my first experience in war. 
Ichiro Hashimoto, another fourteen-year-old student factory worker, recounts his experience that same day and reflects on the events to follow.

I remember that day clearly. When the bombing started, I panicked, trying to run from the city, and a Grumman came after me. It was not a large plane, just a fighter jet with one pilot. There was no bomb shelter around, only the road by the river. It terrified me. Fortunately, I saw a bridge nearby, so I ran and hid under the bridge as he continued shooting at me. After that, there were air raids every day and I grew used to them eventually.

Just as the people feared, the air raids came again the next day, dealing heavy damage to the Oita Naval Air Base, $12^{\text {th }}$ Naval Air Factory, and the areas surrounding eastern Oita. It was not just Oita City, however. Saiki Naval Air Base and Usa Naval Air Base were also attacked. In Usa, they were attacked three times in one day between 13:00 and 15:30, killing fourteen people. Usa was headquarters of the $3^{\text {rd }}$ Squadron of the $721^{\text {st }}$ Special Attack Group, or Tokkotai, a kamikaze operation led by Captain Morimasa Yunokawa. He had a total of 32 men in his unit between the ages of 20 and 24, all volunteers. This unit arrived in Usa in mid-February, preparing for a suicide attack on the American forces approaching Okinawa in the following month.

After arriving in Usa, I spent most of my time simulating battles on maps. We focused on how to disable the American forces in one big blow, hitting their eight largest vessels around Okinawa. We contemplated the probable locations of the ships and tried to formulate the best attacking strategy. This was done indoors, but we'd also train in the air and on the ground. I trained about 200 pilots, two died and one was seriously injured during these training. But the rest of us felt confident in carrying out our mission. Other units that were not kamikaze were also stationed in Usa, and with whom we sometimes socialized, going for drinks in Usa or Beppu. But by mid-March, most of them had been shipped to the front, only one other unit stayed in Usa. My unit was scheduled to depart for our mission on March 18. We had made our visits to Usa Shrine in the weeks leading up to the attack and were prepared, physically and mentally, to fly out that day. On March 18, at 15:30, we were all ready. Our engines were running, we lined up in front of a table, raised our cups to have our "last drink" of sake (in fact, the drink was ceremonial water) when American planes appeared suddenly. The surprise attack was so well executed; I had no time to give orders. Everyone was running around frantically. I watched and thought to myself, we were screwed. I heard the sound of our machine guns up on 
the second floor of a nearby building, trying to shoot down the planes. My pilots had scattered all over the place, looking for shelter. There was not much I could do, so I went up to the machine gunner and encouraged him to keep up with the good fight and asked him if he needed anything. He wanted water which I promptly brought to him. Then came a second wave of attacks. I saw the faces of the American pilots and noted their flight scarves. I don't remember what I did immediately after the attacks, but I do remember thinking, “Ah, shit! Damn!” Eleven of our eighteen planes were destroyed. My unit was ordered to regroup in Miyazaki.

Despite the destruction of Captain Yunokawa's unit, kamikaze airmen continued to gather in Usa for the next three months, launching a total of five missions from Usa on April 6, 12, 16, 28, and May 4. A total of 81 kamikaze planes flew from this small coastal town and 154 pilots lost their lives. If one visits Usa today the memory of these 154 men is enshrined in parks, monuments, and museums around the town.

Usa was just a small farming and fishing town, with informal relations between the military and the citizens. Fourteen-year-old Takafumi Yoshimura witnessed the March 18 attack on Usa.

I sure do remember the attack on March 18, 1945. I was playing near the naval air base that day when I looked up in the sky and saw airplanes headed toward me. There were no air raid sirens, so I thought they were Japanese planes. Then the shooting started. The airplanes flew so close that I could even see the pilots, so I started running with all my might. These were the first Grumman planes I saw, but more were to follow. There were about ten of them that day, and they circled back many times. It happened so fast, there was little resistance. I did not see any Japanese planes fly up to meet them.

The American military did not just target the bases and the factories. They wanted to destroy supply lines in order to undermine Japan's defense of Okinawa. On March 18 and 19, trains carrying civilians were attacked, some in small villages. On the $18^{\text {th }}$, on the Nichibun line, around Kouzaki, a conductor and passenger were killed and many passengers were injured. Then in Satsuki five passengers were killed. On the $19^{\text {th }}$, one conductor and passenger were killed in Nakahanda and in Usa's Tateishi, one conductor was killed while another was severely injured. ${ }^{6}$ 
Masaaki Yano in Kitsuki recalls one eventful day the Grumman planes flying over his home, the local manor house that sits next to a Buddhist temple and overlooks rice fields and a river. Just beyond the fields stretches the train line snaking down the coast of Kyushu between Kokura and Saiki. "One day the Grummans flew low over the tracks, targeting a train full of people. The train was shot up, with many people dead and injured. Some of those were carried up the hill to the temple, where they were cared for as well as they could be. My family members ran to the train and helped carry the injured to the temple. As attacks on these tracks increased the conductors began making brief stops at the train platforms to decrease the chance of being hit. After the attack on March 19, the sirens went off daily. People lived in fear and grew weary of dwindling supplies and weary of tough conditions."

Hiji, sandwiched between the air bases of Oita City and Usa, saw the occasional dogfight overhead. While air defense was getting weaker by the day, there was still some fight left in the limited number of Japanese planes and their pilots. Reiko Waki, a young student taking time off from her factory work in Oita City, remembers watching one of these battles. "One day I saw an aerial fight between a Grumman and a Zero above Mt. Kangoe in Hiji. It was like I was watching a movie. Later the body of the Grumman pilot was found at the shoreline of Toyooka. He was buried in a field nearby with respect by Hiji city leaders."7

The war grew closer as the specter of death surrounded Oita. Families throughout the prefecture now regularly mourned the loss of their sons, brothers, and husbands as the brutality of the fighting intensified around the Pacific. The local newspaper did not flinch from reporting the high rate of mortality among the local soldiers, and highlighted some of these deaths with photos and brief biographies of the men in a regular special section. The March 18, 1945, edition of Oita Godo Press is but one example. Under the headline, "Profiles of Three Soldiers," readers found the following:

Yashio Jinno, $1^{\text {st }}$ Class Fireman,

Born in Ongubaru, Ohno-gun,

Killed in battle, winter last year

Katsusaburou (59) father, Ima (57) mother, Haruo (38) eldest brother, Ukie (34) wife with five children, Yoshio's younger brother Yuichi (20) is an active volunteer in the army in Manchuria.

7 Akinori Endo, ed., Memories of Youth during the War, Association of Reminiscences: Record of Student Mobilization by Secondary School Students in Oita Prefecture, Oita City, Oita Prefecture, 2005, pp. 69-70. 
Tameyoshi Fujiwara, $1^{\text {st }}$ Class Fireman

Born in Kohazama, Ouchi, Kitsuki-machi,

Killed in battle in Manchuria last summer

Yoshi (65) mother and three brothers, Terunaga, Hajime, and Hitoshi are engaged in farming at home.

\section{Teiichi Okubo, $1^{\text {st }}$ Class Sergeant}

Born in Nishishonai-mura, Resided in Kaneike, Oita City

Killed in battle in the South Pacific in winter the year before last

Hanayo (29) wife, Kasunobu (11) and two other children are left at home.

By the time the American forces landed on Okinawa on April 1, people in Oita were already feeling the effects of this massive battle through the growing number of attacks all around them. They understood that the Americans were attacking the air bases throughout the prefecture in order to keep Japanese planes away from Okinawa, and that they sought to improve their odds by destroying planes on the ground. The Americans' fear of kamikaze attacks, many departing out of Oita City, Usa, and other nearby bases in Kyushu, was central to this concern. The bombing was merciless.

On the island of Okinawa itself, American and Japanese ground forces engaged in one of the most brutal fights in the history of warfare, one that could decide the future of the war. As American bombs fell around Oita and other parts of Japan, American sailors nervously watched the skies for kamikaze.

E.B. Sledge and Don "Slim" Carlton were two young Marines preparing to invade Okinawa. Sledge recalls:

After maneuvers were completed, our convoy sailed from the Russell Islands on 15 March 1945. We were bound for Ulithi Atoll where the convoy would join the gathering invasion fleet. We anchored off Ulithi on 21 March and remained there until 27 March.... At Ulithi we received briefings on the coming battle for Okinawa. This time there was no promise of a short operation. "This is expected to be the costliest amphibious campaign of the war," a lieutenant said. "We will be hitting an island about $35^{\circ}$ miles from the Japs' home islands, so you can expect them to fight with more determination than ever. We can expect 80 to 85 percent casualties on the beach." A buddy next to me leaned over and whispered, "How's that for boosting the troops' morale?" ... "Be on the alert for a Jap paratrooper attack in our rear, particularly at night. It's pretty certain the Nips will pull off a massive counterattack, probably supported by 
tanks, sometime during the first night ashore or just before dawn. They'll 'banzai' and try to push us off the beachhead."

On 27 March the loudspeaker came on with, "Now hear this, now hear this. Special sea detail stand by." Sailors assigned to the detail moved to their stations where they weighed anchor.

Tension mounted on the eve of $\mathrm{D}$ day. We received final orders to move in off the beach as fast as possible. We were also reminded that although we were in regimental reserve, we would probably "get the hell kicked out of us" coming on the beach. We were advised to hit the sack early; we would need all the rest we could get.

A predawn reveille ushered in Easter Sunday - April Fool's Day - 1945. The ship seethed with activity. We had chow of steak and eggs, the usual feast before the slaughter. I returned to our troop compartment and squared away my ammunition, combat pack, and mortar ammunition bag. The ship's crew manned battle stations and stood by to repel kamikaze attacks. Dawn was breaking, and the preassault bombardment of the beaches had begun. Above it I could hear the drone of enemy aircraft inbound to the attack. ${ }^{8}$

Carlton, in another ship of the same convoy, writes:

We finally assembled as ordered.... The officer began, "We are ... heading for the invasion of Okinawa." "Where the hell is that?" A man behind me muttered. "Never heard of it," his buddy answered. The officer enlightened us.... Unfortunately, the island contained many civilians who were not to be trusted. "What about the civilians?" a man asked. "Do we kill them or let them go?" "You'll have to play it by ear," was the answer. Hopefully they'll get out of our way, do not trust them."

"How about prisoners?" "Due to logistic difficulties, you will take no prisoners for the first three days. Is that clear?"

The last day of March arrived. Tomorrow would be April Fool's Day and Easter Sunday. Chaplains conducted services. Catholics received Absolution and Communion. A "special" dinner was served, but I cannot recall the menu. I looked at the men around me. Fear was evident on many faces; mine was one of them. How would the landing be? Would the enemy rip us to shreds before we reached the beach? Would we get pinned down and decimated on the beach before we could move inland? All these, and other thoughts, filled my mind. ${ }^{9}$

8 E.B. Sledge, With the Old Breed (New York: Presidio Press, 1981), pp. 195-201.

9 Don "Slim" Carlton, Wanna Live Forever? (Lincoln, NE: iUniverse, 2005), pp. 12-13. 
Colonel Hiromichi Yahara, chief military strategist for the Japanese troops on Okinawa, recalls the importance of air power to the success in winning the battle. Writing in his memoires after the war, he recalls the optimism of Japan's air superiority in the early days of the battle:

In early April 1945, seemingly authoritative information came from one of the secret special service organization units in Harbin saying that if our air attacks on the U.S. Navy could continue for another ten days, the enemy would be forced to break off operations on Okinawa. This lifted our spirits and led us to believe that we might again succeed in regaining enemy occupied territory. ${ }^{10}$

On April 6, aboard the American minesweeper USS Defense, all eyes were on the skies, watching for approaching kamikaze. One young sailor on this ship, Carroll Williams, from a small town in Ohio, fashioned a rough poem after that week to hand down to his children. His reflections show why in early April the Japanese command had hopes for these special attack missions and why the American bombing of air strips and aircraft repair factories was so relentless.

5 Minutes of Hell

April the sixth, a day on my mind.

A day to remember, the rest of my time.

The Japs came down, about 4 o'clock,

Dropping from clouds like showers of rocks.

Off went the alarm, our guns we did mount.

Planes coming in, we began to count.

One on the port, coming in low.

A suicide dive to wipe out his foe.

The plane is just about to hit.

The Jap, he must have lost his grip.

The plane shot up into the air.

The twenties marked him for their fare.

Our faces looked just like a bell,

We had knocked that Jap to hell.

Rejoicing was not yet to come,

Other planes were making runs.

Our guns we did then mount again, 
Waited for the planes coming in.

A twenty then did open up,

Shot at a plane coming at us.

The plane was hit; it swerved around,

The pilot knew we were out of bounds.

He headed down, a long, low glide,

And hit a destroyer on the side.

We looked around, two more were to come.

We waited for them with ready guns.

The planes came flying out of the sun,

One on the stern, one on the bow;

Everyone thinking, I hope God's my pal.

A hell of a thing, those planes coming in,

Living death flying on those wings.

The nerves of our stomachs were knotted and tight.

Every man's face was filled with fright.

One on the bow was now coming in,

Swooping low like a flying fiend.

We poured everything at his flying plane.

He did not stop, for on he came

We shot him down, just below the bow.

The sound of his crashing was mighty loud,

A terrific explosion, it shook the clouds.

A crash of lightening, the thunder roared,

Like flashing the hammer of the mighty Thor.

Some were wounded in the crash of the plane.

Their minds will never be the same."

\section{April 21, 1945}

While Americans and Japanese killed each other without mercy on Okinawa, the citizens of Oita City, Usa, and Saiki dreaded attacks daily. Air strikes came primarily from two sources. First, bombing and strafing from the Grumman Hellcat, known throughout Japan simply as "Grumman,"

11 Carroll Williams, "5 Minutes of Hell - Poetic Reflections of the Battle of Okinawa and Kamikaze Attacks on the U.S.," 17 September 2016, http://hubpages.com/education/5-Minutesof-Hell-Poetic-Reflections-of-the-Battle-of-Okinawa-and-the-Kamikaze-attacks-on-the-USInvasion-Force. 
brought the close-range attacks. Use of the Grumman continued throughout the war for low-altitude attacks and reconnaissance. The second, and most frightening, were the fire and delayed action bombs from General LeMay's B-29s.

It was the attack on April 21, 1945, that stands out as one of the most memorable and tragic days of the war for the young students working in the military factories around Oita City. That morning, the sirens went off at 6:18, followed by an unfamiliar thunderous rolling sound. As people looked to the sky, they saw the outlines of B-29s flying high overhead. They had seen these planes before, but in those cases they had bypassed Oita for larger targets to the north of the prefecture. Then at 6:50 a.m. bombs began to rain all around them. Parts of the city were ablaze. The areas around Oita station were destroyed and trains rendered useless. Many houses burned and scores of people died. Two hundred bombs later the planes left and the sirens went silent.

The military factories kept working, as they had escaped bombing. However, just when everyone thought the worst was over, one single B-29 bomber flew over Oita. The target was the $12^{\text {th }}$ Naval Air Factory's third plant.

The searing memories of this day never left those who witnessed and survived that day. Ichiro Hashimoto remembers:

It was fourteen minutes past noon when a bomb landed on our factory. Nineteen of my friends, all student workers, were killed instantly. There had been no evacuation alarm. A total of 70 people died from this one bomb. Had I been at my work station I would have been killed along with them. By a stroke of luck, I was away on an errand at that time. I remember clearly people screaming and one girl crying out, "It hurts! Help! Please!" In the aftermath, when we cleaned up the scene, blood and bodies were everywhere. The machines fell on people; the second floor collapsed and crushed the skulls of people; and brain matter spattered all over the place. I still remember every detail.

The students that died were all close friends of mine. When we had first reported for work at the factories, my teacher divided us up according to where we lived. The boys who had sat all around me, in front and in back, to my left and to my right all died that day. So many people died in the factory that day we held a mass cremation by the river. There was no special ceremony for the dead students; there wasn't anything we could do for them during the war. The factory as an organization did nothing. But individually, some of us went to the homes of our dead friends and prayed with their families. After the war, the sister of one of 
the boys erected a memorial statue at Uenogaoka High School [called Oita High School during the war] where most of the dead boys had studied. The statue shows a teenage boy in military uniform, down to the army leggings we all wore. Now, every year on April 21 we still go to Uenogaoka High School to remember those perished on that day. The bombing on April 21, 1945, is something I can never forget.

Twelve-year-old Yoshio Ninomiya was walking by the river in Oita after the bombing, and he watched from a distance as people disposed of the bodies. "The people who died in the bombing of the factory were still in their work uniforms when they were taken to the river. I happened to be there and I watched from some distance. I saw about 30 to 40 bodies lying by the river as the burial workers poured gasoline over them and set them afire."

While word spread quickly around Oita City that something terrible had happened, the local newspaper covered neither the extent of the bombing nor the deaths of the students, so the details of the deaths and cremations were kept quiet and known only to those directly affected. In the April 22 Oita Godo Press, a sanitized and brief mention of the bombing appeared on page 2 .

B-29s recently reconnoitered over Oita repeatedly, aiming at two important facilities on the $21^{\text {st }}$. Air raid alarms were sounded at 6:25. Three formations of B-29s, two of nine, another of ten planes, intruded into Oita City from the southeastern sea at 8:10. About 30 B-29s came over the Bungo channel to drop a series of bombs. They dropped some middlesized bombs and combinations of time bombs with incendiary bombs. Damage was minimal. The air raid alarm sounded an all-clear at 9:23. Later, however, two more attacks were made by one, maybe two, B-29s at 12:21 and 1:25. No damage was reported by these attacks. Although all Oita citizens fought for air defense courageously, we still have concerns with these attacks. At no time should we relax our defensive vigilance. ${ }^{12}$

On the same day that Oita City endured this bombing, Usa's naval air base also felt the force of an American attack. According to official U.S. military reports, the $21^{\text {st }}$ Bomb Squadron of the $20^{\text {th }}$ Naval Air Fleet sent 29 planes to drop 545 bombs on Usa. The official U.S. report on this attack was titled, "Assist War Efforts in Okinawa by Destroying Japanese Air-Naval Base." Half of the bombs were standard $225 \mathrm{~kg}$ bombs and the other half were 
time bombs set to explode between 1 and 36 hours after impact. The planes departed from the Marianas for this mission. By official American count, nine Japanese planes were immobilized on the ground, while eighteen turret guns, three barracks, two plane shelters, and an electric power plant were put out of action. Two air strips also suffered damage. No American plane was downed or damaged, as there was no meaningful resistance from Japanese forces due both to attrition and to concentration of air attacks on American ships in and around Okinawa.

The bombings of Oita City and Usa on April 21 were considered "highly successful" by General LeMay and his air commanders. Photos taken from the American planes showed an "excellent bomb path with many hits on hangers and administrative buildings and several planes visible on the ground were destroyed. No flak was encountered over this airfield." Multiple types of bombs were dropped over Oita City from seventeen B-29 bombers. These included 170 time bombs, so feared by the populace, who had no idea when they would explode after hitting the ground. These AN-M64 bombs were programmed with different delay mechanisms in order to "extend the effectiveness of the bombs." This strategy was aimed to prevent quick repair of runways, roads, and airplanes, as the bombs could go off at any time. At the same time, this intimidated and demoralized the citizens living in these areas. The numbers of time-delay bombs dropped over Oita City that day included the following:

9 one-hour delay

9 two-hour delay

50 six-hour delay

$5^{1}$ twelve-hour delay

34 twenty-four-hour delay

17 thirty-six-hour delay ${ }^{13}$

The attack on Usa saw 29 planes dropping 136 tons of explosives with a similar ratio of time-delay bombs. Other attacks would soon follow, making any meaningful recovery impossible. Yet the government of Japan would not acknowledge the obvious, thus ensuring that many thousands more would continue to die needlessly. While these bombs were falling throughout Oita, the battle for Okinawa intensified. Don "Slim" Carlton recalls: 
We advanced unopposed for a couple of days. At last we moved into a road cut and were told to dig in.... Toward the enemy was Hill 178. To take it from the enemy would become a bitter battle.... A short time after Tony, my new assistant gunner, and I finished digging the foxhole behind the gun; a small patrol came up behind us. "Looks like they're going to test the area in front of us," Tony observed. The patrol consisted of four riflemen and a guy toting a flamethrower. "Good luck, guys," I said as they passed.... They had only advanced twenty yards when mortar shells rained down on them.... The men started to crawl back. The man dragging the flamethrower was not lucky. A mortar round landed close to him, throwing him in the air. When he landed, we could see both legs had been blown off at mid-thigh.

Then a strange thing happened. A Jap soldier less than ten feet in front of me stood up. He did not turn and run, but stood motionless staring directly at me. His arms were motionless at his sides. Was he surrendering? Too bad. This was one of the bastards who were killing our men yesterday. I pulled the trigger several times. A look of surprise appeared on his face. Dirt flew from his shirtfront. He tumbled backwards. ${ }^{14}$

\section{No Place to Hide}

By late April hardly a day passed without the sound of air raid sirens. As the eerie sound of the B-29s approached, the people wondered if this would be the day they would die. Ichiro Hashimoto recalls:

During the B-29s bombing campaign, whenever the sirens went off, especially if we were walking to work in our assigned factories, we'd run back home. At one point, no buildings were left standing anywhere in sight. The incendiary devices burned almost everything. Miraculously, my house and the house right next door to ours survived the bombing, while all other buildings along the way were burned to the ground. Later we recovered bomb shell casings in my neighborhood and donated them to the metal factory.

Trying to maintain a sense of normalcy while waiting for the next attack, the younger children were sent off to school, and women carried on their morning shopping and housework. But nothing was normal, and routine lives proved impossible to maintain for long. People recalled later the 
deafening thunder that shook the air as the American pilots increased their attacks. Residents dashed to their shelters when the bombs started to fall; they felt the ground shake violently; they heard their homes, shops, and streets being ripped apart; and they held hands in their dark shelters, praying for the bombing to stop.

When the bombers left, people came out of their shelters and gathered together to see how their neighbors fared. In one neighborhood, a bomb fell directly on top of one house, killing a family of four. Panic set in, and speculation spread that an American aircraft carrier had entered Beppu Bay. People feared that the American planes were bound to come back again and they realized they were not prepared to withstand these attacks, as their air raid shelters were practically worthless. Why, many asked, had neither the government nor the military instructed them how to construct proper shelters? They were left to their own devices. Some dug tunnels in the soft limestone of the surrounding hillsides, but they could not always get that far away on short notice. Others just dug shallow holes and tried to cover them with whatever they could find.

Ichiro Hashimoto recalls, "I lived just behind Oita station in the middle of the city. After the bombing started, my family ran outside the city to a shelter we had constructed. But looking back now, the shelter wouldn't have done any good. We just dug a hole in the ground and covered it with wood. Not that we had any choice to do otherwise." Masaaki Yano's family in Kitsuki dug an air raid shelter in the garden just outside the front entrance of the house. "Each house had their own shelter, but I don't think such shelters were effective. Nevertheless, it was the only place for my family to escape into to try and save our lives."

People in the center of Oita City realized a normal life was not possible, and they began sending their children to the countryside to keep them out of harm's way. Before long, entire families followed. Misayo Hamasaki recalled:

People were confronted by other challenges, even in the simple matter of clothing and diet. Traditional kimonos for everyday wear were replaced by more practical trousers, which allowed women to run away from bombs, as well work more effectively in the fields and factories. Young men wore military uniforms even while doing civilian work and in school, so that when they were conscripted, they'd already have their uniforms. By the end of the war, no clothes were available in stores; all were made at home and altered when necessary. Food became so scarce, that ration coupons were used for salt, sugar, and other staples. Eventually, even the 
coupons were not always accepted, and a lottery was set up to decide whose coupons would be honored.

On April 26, the B-29s returned to Usa. Machiko Mamasaki recalls the bombing and the chaos of the following days in lively detail. Her father and brother were away fighting, and she lived alone with her mother.

It was an unforgettable morning. The B-29 air raid sirens wouldn't stop going off, as the bombs fell. From the eastern skies, 27 fighter planes and two B-29s flew in a westerly direction. My mother called to me, "Machiko, go to the shelter quickly!" We ran quickly into the shelter. Our air raid shelter was only a few meters away from our house along the Choshu Road toward Usa-Miyagu, under the fields, diagonally into the ground. It could hold about 20 people and was easily accessible. It was dark inside, and I'd hold myself tight as the earth trembled with the thunders of the bomb explosions. We could figure out that the sounds came from the Yanagaura direction. Eventually the deafening sounds faded into the distance.

It was my first bombing experience, with the ground shaking so eerily. The grown-ups speculated that the Usa Air Base, which was only a couple hundred meters away from our shelter, must have been the target. Emerging from the shelter, we saw thick black smoke coming from the Yanagaura direction. Someone came running toward us yelling, "All of Usa has been attacked." At that moment the B-29s had turned around, flying even lower. "They're coming back" everyone screamed as we sprinted back into the shelter we had just come out of. Within five seconds of getting back into the shelter, we heard the bombs whistling above our heads, followed immediately by repeated explosions. It wasn't just one or two. The ground shook and the shelter came crushing down, dirt falling all over us. We couldn't move. "Machiko, be brave," my mother said repeatedly in a faint voice. What was going on? What were we supposed to do? We gathered together in the middle of the shelter and held on to each other tightly.

The sound of the bombs grew faint; the sound of destruction grew faint. We were all safe but no one could speak all still shaking with fear. Finally, we got out of the shelter, shaking the dirt off our clothes. Scared and shaky, we headed toward the road once again. It was a surreal sight. Half of Nansho-san's mansion, which stood out so prominently just before the bombing, disappeared. His spare house was nowhere to be found. Power lines along the road were down, and the poles split in half. Roofs, 
doors, and walls of houses in the area were gone. The roof of my house was blown off, and the house leaned to one side. A hole big enough for two adults to walk through opened in our kitchen wall. Everyone was puzzled about the hole. We looked into the hole, but it was too dark for us to assess the extent of the damage. We soon found out Nansho-san and one of his workers died in the bombing. I was terribly upset that my house had been hit, but the feeling of my neighbors' death was even more overwhelming. All of a sudden, I started running toward the road. I wanted to escape from the horror in front of me.

Apparently, the worker had run into Nansho-san's house thinking he'd be safe. However, the bomb hit squarely on the house and he had no chance. Nansho-san's wife had attempted to run to the shelter, but when she realized that she was too slow to reach the shelter in time, she wisely jumped in the river instead, which actually saved her. When we got to what remained of her house, she was crying as she picked up body parts of her husband off the ground. If this wasn't hell, I didn't know what was. We helped her pick up pieces of the worker and Nansho-san with chopsticks and put them in boxes.

As Nansho-san's wife thanked us for helping her, a neighbor came running. He was out of breath and muttered that Iseban-san was dead. Iseban-san was a Korean man who lived by himself by the lake. He tended fields and collected garbage from people. Many of us went to help. He'd been killed by the shock of the bomb blasts. He looked like he was sleeping. We had a funeral for him by the lake.

It was evening by the time my mother and I could return to our own home. Mother and child, we had no idea where to start cleaning up. We began by taking all of the broken furniture outside. As we were working, people from all over the village came to help us. Then the police came and informed us that the big hole on our kitchen wall came from a time bomb, and it could go off any time. They ordered everyone to evacuate immediately. Scared, we went to stay at a friend's home about 300 meters away. We spent a sleepless night. Early the next morning, a young man and five of his friends came. He said to my mother, "I know it's difficult because the time bomb had not gone off yet, but is there anything you absolutely need from the house?" My mother replied, "The road up to our house has been roped off and no one can get in. We don't know when the time bomb may go off. I appreciate your kindness but I beg you not to go there." The young man replied, "We've already been drafted and we are leaving for the front soon. It doesn't really make a difference where we die. So please let us help you." 
Mother thought for a minute and said, "If this is true then I do ask that you take out our shrine. It was furthest away from the kitchen and wasn't damaged. If you can carry it, please get it for us."

"Yes ma'am." The young men took off running toward our house.

They brought us the shrine and three bags of rice from the house. I still pray to that shrine today.

The second night came, and I was still shaken and couldn't sleep. On the third day, at five in the early morning, we heard a large boom. The windows shook. "What was that?" We went outside to take a look and found dark smoke coming from where my house once stood. There was nothing left. My mother fell to the ground in tears. I cried, too. The man at whose house we were staying said, "Your house may be gone. Everything may be gone. But we will go on. Think about it, had you not left the house, you and everyone else helping you would have been dead. Be happy that you lived. As long as you're alive, you can go on." I agreed, but couldn't stop crying.

The area around our home would get attacked repeatedly by the Grummans with their rockets and bullets, but there was not another incident so destructive as that one. Three houses were totally destroyed, and 25 others were either burned or severely damaged. There were eight deep holes in the ground that filled with water on the lot where our home used to stand. But we rebuilt a house and we put the shrine back in its place. ${ }^{15}$

Seiji Oki recalled a similar encounter in July 1945 near Usa:

One morning at 8:30 after an attack, we came out of the shelter to find a priest from the local shrine all shaken up. He'd already gone around town checking on people and said, “There's a bomb hole at Norio's house. We went with him to Norio's house and found a number of people there already. Right in the middle of Norio's yard was a hole about three meters in diameter. No one really understood why there was a hole there. It was like nothing we had seen before. After suggesting that maybe everyone should evacuate the area, the priest went to inform the police.

The police and the fire department came, as did officials from City Hall, but no one knew what to do. So the policemen went back to the Police Department to receive instructions. In the meantime, people peered into the hole with trembling hearts. I was so scared that I went straight home and hid in the shelter. As it turned out, the hole was made by a 
big time bomb. A police officer went around the neighborhood on his bicycle shouting "Evacuate!! Evacuate! Evacuate the area now!!” The police, firemen, and city employees were exhausted from riding around on their bicycles to help people stay safe.

About twelve hours later, as my family's farm helper was getting ready to feed the cows, the ground shook like a huge earthquake. It rocked so hard that our shelter started to cave in. Not knowing what was going on, our entire family held each other tightly. Then, we heard someone shouting "It went up!! It went up!!" We came out of the shelter but nothing looked out of the ordinary. The helper said, "The bomb went off at Norio's house!" We went to look at Norio's house. The house had shattered to pieces as if it was dropped from high up. Apparently, the house had gone straight up and come straight down with pieces landing 30 meters away. Because everyone had evacuated, there was no one injured that day. But that was when I learned how horrible time bombs really were. ${ }^{16}$

\section{Filling the Craters and Building the Shelters}

Following the attacks on Usa, a group of students from a nearby town were sent to help rebuild the air base. They stayed there for two months, dodging periodic American attacks and learning what it meant to sacrifice for the Japanese war effort.

I entered Nakatsu Middle School in early April, 1945, just as Japan came under heavy attack. That was the end of my schooling for the time being. The students in higher grades had become student laborers already, working in factories all over Japan. Now, we first-year students received our orders. We were sent to Usa Air Base and had no clue what kind of work awaited us. Though with some trepidation, I looked forward to it. In the beginning of April, nervous yet excited, my friends and I gathered at Nakatsu station. Two hundred bright, young faces scattered around the area. The 7:30 train started moving. As we got closer to the Yanagaura station we were told to close our curtains as spies could be watching. But we stole looks out the windows anyway, hoping to catch a glimpse of something new or unexpected.

16 Mitsumaro Fujisawa, ed., The World of Usa Air Force V (宇佐航空隊の世界V) (Usa: Toyonokuni Usa Academy, Soei Hirata, 2012), pp. 48-49. 
When we arrived at Yanagaura station, training officers in uniforms met us. They looked smart as they bowed to our teacher. After exchanging a few words, they split us up into five groups. Off we went, following the officers. We headed down a dusty road to the air base. I had expected to see planes lining the air strip with properly uniformed pilots coming to greet us. But once there, we were shocked to see a lone plane sitting on the runway. It had been destroyed by the Grummans in March. My expectations were but a dream. A bomb had left a small crater, 20 meters in diameter, next to the destroyed plane. Reddish muddy water filled the hole. "Your job is to fill this hole!" shouted the officer. We had all fantasized about being a part of more meaningful work and started whining about it. Our school teacher turned around and scolded us.

We then climbed into trucks and headed away from the base. Along the roadside stood planes camouflaged by bamboo and dirt. They must have been sprayed by Grumman bullets, because they were all covered with bullet holes. There wasn't a single plane that was left fully intact. Could we really win the war like this, I wondered?

Eventually the truck stopped at the bank of the Ekkan River. There, five soldiers were waiting for us. They paired us up, giving each two-person team a pail and a thick wooden shoulder pole to carry the pail. We put the bigger, flat rocks at the bottom of the pail and then filled the sides with smaller rocks. Because it was our first time, we didn't know how to do this efficiently. Until we learned to breathe and move in synch, we'd spilled the rocks along the way. We filled the trucks with rocks. Once the trucks were full, we would ride on the truck back to the air strip. Riding the truck felt good with the cool breeze against us.

Once we got to the air strip, hell awaited us. We stuffed the pails with rocks once again and unloaded them into the bombed-out hole. Because the hole was so big, it took 40 of us about two weeks to fill it.

After we finished filling this hole, there were other air raids, which created fresh new holes in the ground. While we were working, the air raid sirens would go off. When that happened, we stopped working and ran to the shelter on the east bank of the Ekkan River. It was like having a break. Eventually the sounds of the sirens would change to the sounds of explosions and we would get quiet in the shelter, holding our breath until the B-29s passed by.

The warning sirens would typically let us know about 30 minutes before danger approached, but there were times when we had no warning, and the Grummans would shoot at the trucks racing toward the shelter. We were just thankful it wasn't us in the trucks that got hit. 
Our days weren't without fun. At lunchtime, the students spread out along the river, dipping our feet in the cool water as we ate. Because of food rations, our rice balls were made with other grains and came only with salted seaweed or pickled plums. Eventually, we took this time to get to know and enjoy the company of the 20-year-old officers.

After lunch we would sometimes jump in the river and try to catch fish. Four or five of us would chase the fish into a corner and grab them with our hands. We got a full hour for lunch so we got pretty good at catching fish. At the end of lunch we would split the fish evenly and hide them from each other, making sure to take them home in the evening.

When we got done with work for the day, we'd receive a cup of rice to take home. We were treated as hard laborers, and we were always hungry. It was impossible to fill the holes under such physical conditions, so they finally decided to ration us an extra cup of rice each day. But we each had to bring our own bag to carry it. If we forgot our bag, we got no rice. So every morning when we left home, we double checked that we had our lunch and the bag for rice.

Around four in the afternoon, work was done and we'd lined up for rice. Two soldiers rationed out the rice. We always asked them to fill the cup of rice to the brim. The soldier that was generous always had a longer line, even though that meant we had to wait longer. "Hey! The rest of you get in the next line!" they'd yell at us. We couldn't argue so we grudgingly got in the line of the guy who wasn't as generous, thinking that the day had been a waste. Lack of food does terrible things to people.

For about two months we continued to fill the holes; it was not until rainy season came in June that our work was done. ${ }^{17}$

Seiji Oki was a junior high school student in 1945. In accordance with a new governmental command to students working in the war effort, he and others repaired and camouflaged airplane shelters at Usa Air Base.

From May to June, twice a week students from different schools and districts gathered at a meeting place. We'd find out our job assignment for that day and receive the tools we were to use. A commander would give us a quick instruction and conclude it with a yell "Get to it!" We carried our tools and headed to the Usa Air Base where some airplane shelters stood in plain sight. These were 7 - to 8-meter-tall concrete buildings, about 300 meters apart from each other. Our job was to cover the 
structures with dirt and grass to hide them from American planes flying overhead. We found out later, in fact, no matter how well we camouflaged the shelters, the enemy planes spotted them easily. Nonetheless, we followed orders and did our job.

About fifteen or sixteen students and adults worked on each shelter, piling the dirt on the roof of the shelter from both sides. The objective was to cover the structures with at least three centimeters of dirt. This was a task that the kids couldn't stay focused on for long. The commander was nice enough to not shout at us when we were tired or weary. He would encourage us by saying “Keep up the good work! Don't slack off or the enemies are going to get us!" I think he knew that this was a physical job more intense than what middle school kids could handle. Slowly the visible concrete became less and less, and we saw that we were making some progress. Day by day the scenery changed.

From June through July we planted seeds in the dirt. The work was less physical, so it became more fun than going to school. For lunch, we were given rice balls with a nice, big chestnut in the middle and some pickled radishes. I had never eaten this at home but because we were so hungry it tasted really good. Occasionally the commander would bring us extra rice balls if he could get his hands on it. That would make us so happy and he almost felt like a father to us.

Then one day at around 10:00 in the morning the raid sirens went off. Most of the people ran into shrines, temples, or the nearby woods. Following the navy lieutenant's orders, the students evacuated toward one of the military base shelters. There were about 50 to 60 kids from the different schools there. I was surprised at what I saw inside the shelter. There was a 4-meter-wide and 2-meter-tall tunnel carved out that must have been about 50 meters deep. According to the lieutenant, the weapons standing against the wall were the newest 99 rifles. We then entered another side tunnel and as I got closer I was surprised to see even more weapons and tools everywhere. I was at a loss for words and the lieutenant just said "Tour's over."

We settled down and ate our rice balls. Still restless, we went to the entrance of the shelter, looking out for signs of enemy planes, when behind us we heard someone getting slapped and a voice said "I'm so sorry. It will never happen again." I turned around and saw a 50-year-old man, who had come from Shikoku for work, beaten by a 20 -year-old soldier simply because he "doesn't salute properly." I wondered if beating someone while we were in the midst of a war was such a good idea.

One day, when the shelters were almost completely covered, we had just finished eating our rice balls when the sirens went off again. Normally, 
each time the sirens went off, an adult was to direct the students where to go. But this time, no one came. We stood there asking each other "so ... what do we do now?" All of a sudden we heard guns going off in the sky above us.

Someone called out “It's the enemy! Run!!” We scattered instantly like bees out of a nest. Without thinking, I started running west toward my home. I ran through the forest and hid in the train station. Two students had darted into a barn on the west side of the station. It seems the Grumman had seen them because the pilot started shooting at the barn. Peering out of the station I thought my heart was about to stop. Pretty soon, the barn went up in flames and eventually burned to the ground. I found out later that the two kids had slipped out of the barn as the fire started, using the smoke as cover. ${ }^{18}$

In Oita City even younger children were assigned clean up and repair duties. Yoshio Ninomiya was an upper elementary school student in early 1945.

During the last year of the war there was no school, and we all had to work. My classmates and I went to the river bank to collect gravel. We loaded it into trucks, which transported them to Oita Air Base, where bombs had created holes all over the landing strips. We filled those holes with gravel every day from 9:00 in the morning till 3:00 or 4:00 in the afternoon. We did this until the last day of the war. I was twelve years old at that time, and the eleven-year-olds were doing the same.

Other children were assigned to dig air raid shelters to protect military equipment. One was twelve-year-old Toyoki Goto.

We went 8 kilometers outside Oita City where we helped dig a cave in the mountain side. When the military factories were bombed, they moved the repair work to the caves we built. Sometimes we'd be under attack by the American planes while we were digging into the mountain. Once, while we were working, several Grummans came and started shooting at us with machine guns. They flew so close that we could see the pilots clearly. We ran as fast as we could to the shelter. I didn't really feel fear or death, since we'd all been taught that we were going to die soon for our country anyway. If anything, being killed by Grummans would be an honorable way to die for my country. Mostly we were just pissed off 
at them for ruining our work! There were over 20 students working at the construction site, and we were lucky because none of us were killed. I was also happy that, when we went back to work, we found that it was not entirely destroyed. I remember my first thought upon seeing that, "Hey, where's my lunch?”

Some of the younger schoolchildren, like Yasuo Tanaka, were more fortunate in their assignments.

My classmates and I were sent to surrounding villages during planting and harvest seasons. This was because the men were away fighting, leaving only women and old people to work the farm. The students were divided into groups and lived with different families. Our teachers went with us, but they just watched as we worked cutting weeds, planting crops, and gathering vegetables. The farmers were glad to have our assistance, since all the work was done by hand back then, and it was a backbreaking job. For us, though, it was an ideal assignment because in the city we didn't have enough food, while here we worked for farming families who had enough rice to eat.

The role of school girls working in military installations in the final year of the war was fraught with as much danger as that of the boys. In some cases they remind us of the chaos of war, not all of which is associated with bombing attacks. Reiko Waki recalls:

In 1945 I was already fifteen years old. My regular job at the air base entailed handling confidential documents. I assisted an officer who worked on Zero airplanes, some of which were used by kamikaze pilots, including their machine guns, gun sights, and wireless applications. I worked with him on each plane, and I was popular with all the soldiers in that department.

Then, on March 23, 1945, and after the usual lining up and roll call at the air base, some of us played rock-paper-scissors, to see who would go by truck to deliver supplies to factory workers around the base. The winners, one boy and four girls, and I happily climbed up on the back of a truck, waiting to leave. We all enjoyed going out in the truck, as it was refreshing to be outside and everybody enjoyed the truck ride. However, at the last minute, I was ordered to stay behind to work in the office that day. Naturally, I was quite disappointed. My friends comforted me and said I could probably go with them the next day. But, that afternoon, we 
heard the terrible news that there had been an accident and the truck had fallen into a drainage ditch. We heard that all five of my friends had been crushed under the cargo. After work, some of us rushed to the hospital to see them, but they had already died. Light makeup had been put on the faces of the four girls in preparation for their funerals. ${ }^{19}$

The sacrifices the girls made to support the military extended from dangerous work to the lack of daily comforts to the scarcity of medical services. Reiko continues:

We lived in a dorm close to the air base. The food was intolerable. Occasionally, the families of the girls from farms would bring them sweet potatoes, rice, and soy sauce, and they'd share with the rest of us. Also, even though the bath in the dormitory was big enough to hold 30 to 50 people, we had to wait our turn. Soldiers went first, next factory workers, and the students last. By then the hot water was mostly gone, and the pool was dirty. But no one complained. Our slogan was "We never fall down until we obtain victory," which we repeated all the time. Just be patient, we told ourselves, just be patient. ${ }^{20}$

Patience was indeed needed in huge quantities, and tested to the limit when the young girls found themselves unworthy of limited medical attention.

One day while walking in the air base, a needle penetrated my shoe. The sole of my right foot became infected and began to swell. Soon I couldn't walk. I was hospitalized in Nakamura Hospital where my arms and legs were tied to each corner of the bed, and a towel put in my mouth. The doctor cut my foot and cleaned out the infection without using any anesthesia. Anesthesia was reserved only for soldiers.

Masako Sano, a friend and classmate from Mori High School, had an even worse ordeal. One day when an air raid siren sounded, she and other students were ordered to push an airplane to a hiding place by a mountain slope. In the chaos, someone stepped on her sandal, and she fell under the wheel of the airplane. The factory workers at the scene yelled, "Stretcher, bring a stretcher!" She was rushed to the doctor's office at the factory; however, because the air raid siren was still on, she was put in a shelter without any treatment. I ran to find our teacher, who was 
with us at the factory every day, but nobody was in the teachers' room. The aerial attack started, my friend was in danger, and my teacher was not there. I almost cried. But I decided that I must find my teacher. As I was running about the base looking for her, the guards screamed at me, "Hurry up! Evacuate to safety right now!" But I kept running despite the tense and extraordinary atmosphere, listening to the siren and calling for my teacher. Finally I found her at a small shelter in the middle of a peach orchard. She immediately got on her bike, and I ran after her to the shelter where Masako was. Her right femur was broken. My teacher put Masako's head on her knee, stroking her hair softly, encouraging her to "Stay strong, stay strong." Finally the attack ended; Masako was brought back to the doctor's office. The skin on her foot was twisted around the femur and was terribly swollen. The doctor told us to pull up on Masako's upper body, and he pulled down on her bent leg. Nothing changed. Her leg was too badly mutilated, and too much time had passed. She screamed in pain, and the doctor yelled at her, "Don't cry! Clinch your teeth! This is nothing. If you cry, again, I will hit you." Masako didn't say anything, but the pain was so awful she pulled at our clothes so hard our clothes were torn. She was carried to the naval hospital to recover. She never returned to work. She came back to see us only once, using a crutch. And that was the last time we saw her. She passed away not long after that. A fifteen-year-old girl left this world without knowing the joys of life. She was but one of the war victims. ${ }^{21}$ 
Figure 1 Sadayoshi Yutani (湯谷貞義), holding model Zero, with Grandmother, Mother and sister. The photo was sent to his father, but was lost at sea before arriving.

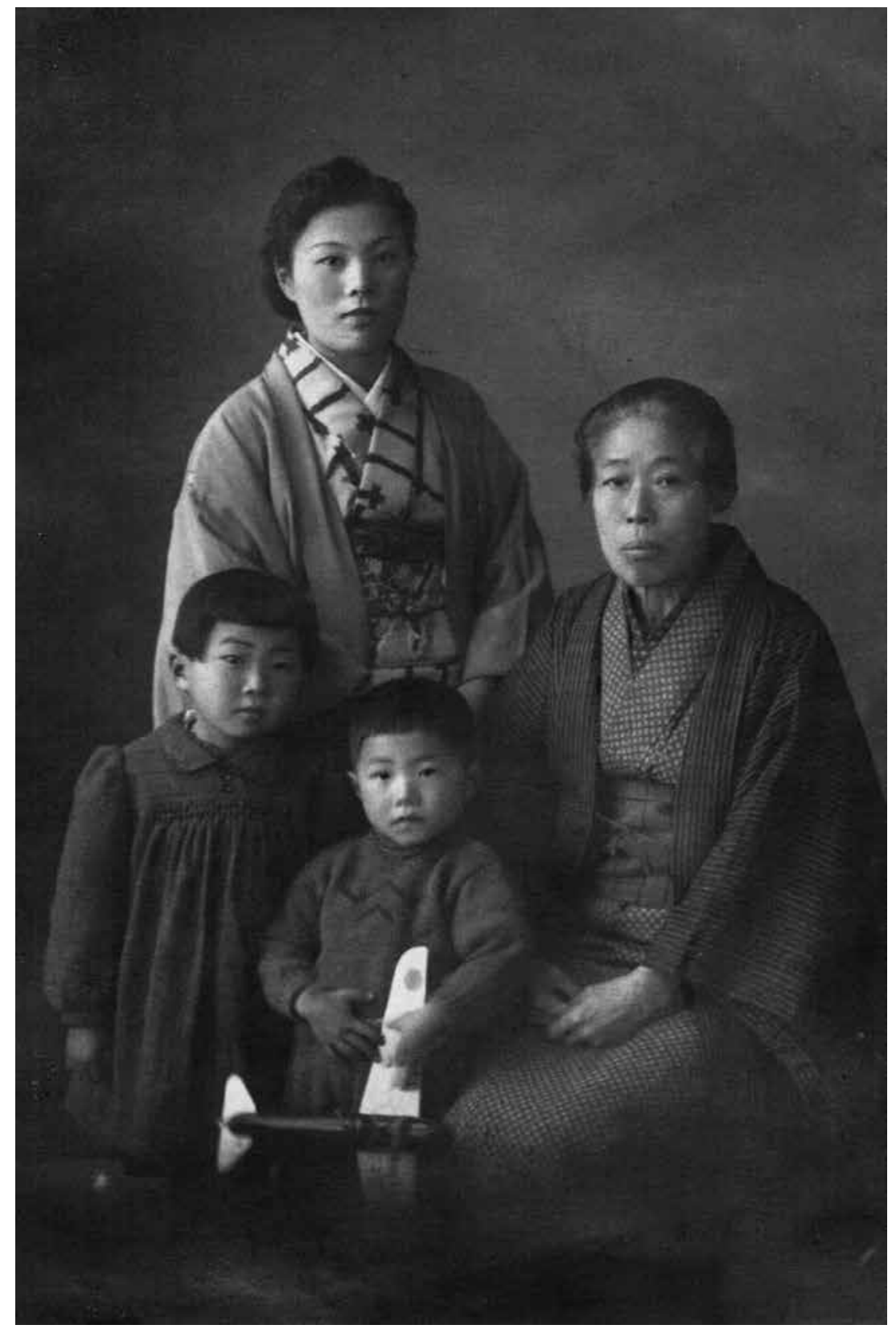

Sadayoshi Yutani 
Figure 2 Inscription reads, "Starting Point of the United Fleet Task Force on Pearl Harbor Attack," Peace Memorial Museum, Saiki City, Oita prefecture

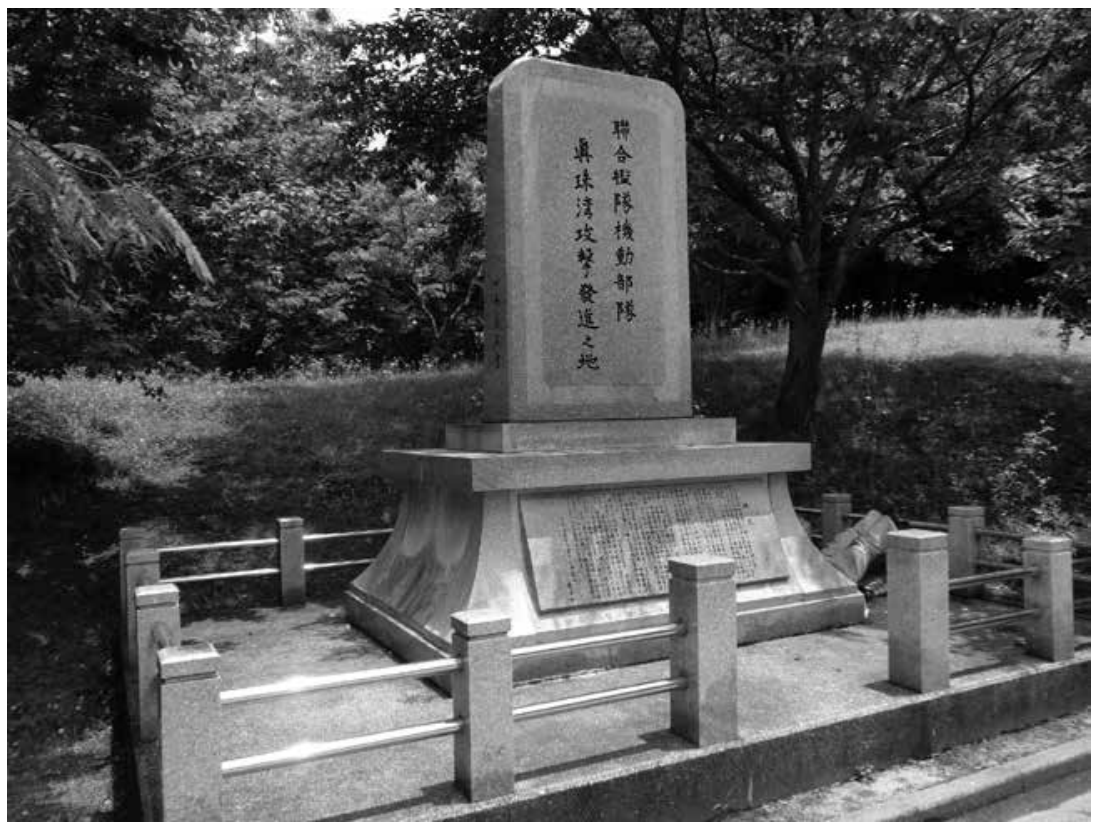

Ran Ying Porter 
Figure 3 'One Japanese soldier acts like 1000 to swallow Asia.'Written by Captain Masanori Hasegawa (長谷川正憲) following attack on Nanjing.

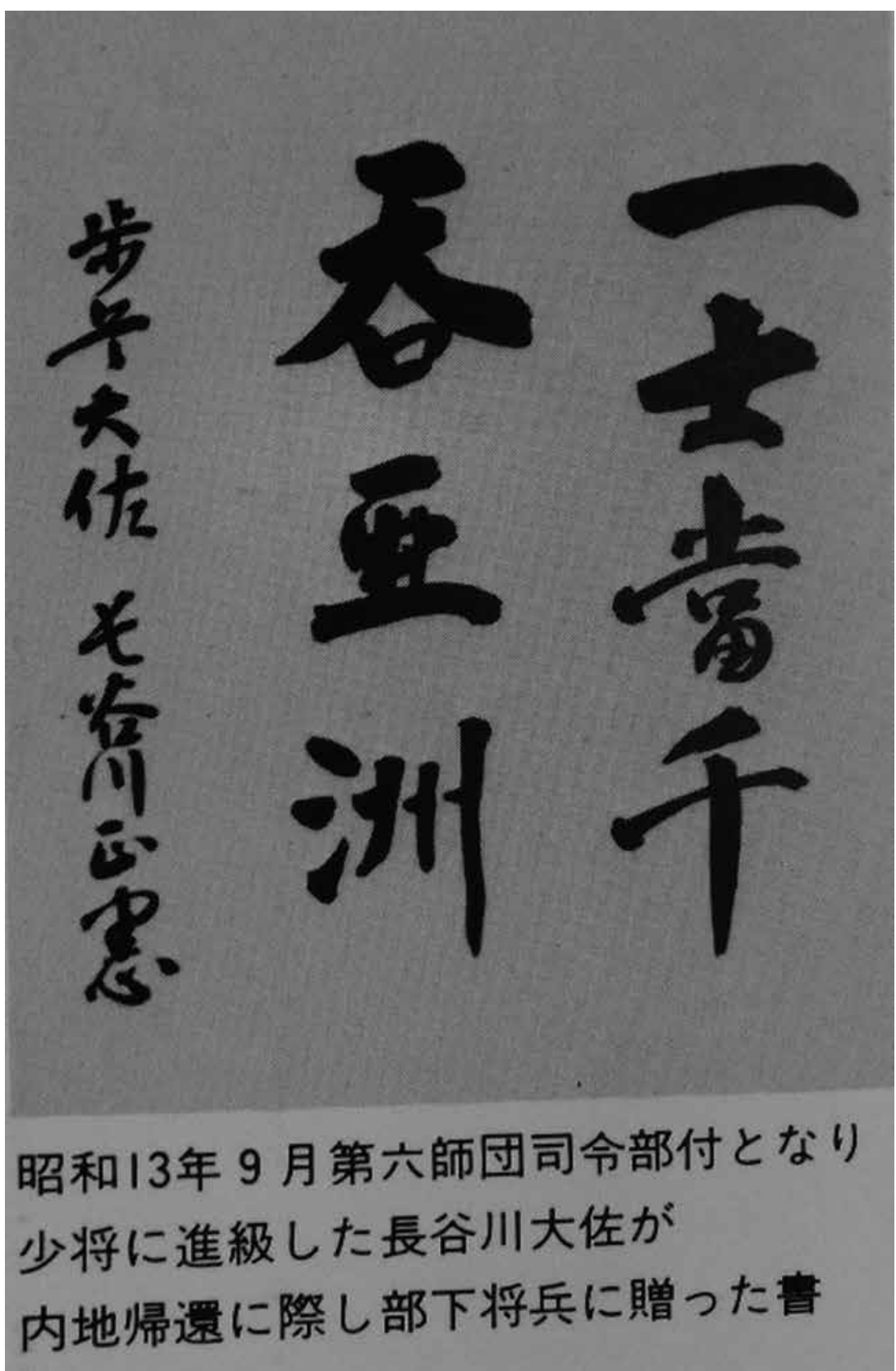

Takashi Hiramatsu 
Figure 4 Oita 47th Regiment Sumo Tournament during break between battles, in Southern Hubei Province, 1939

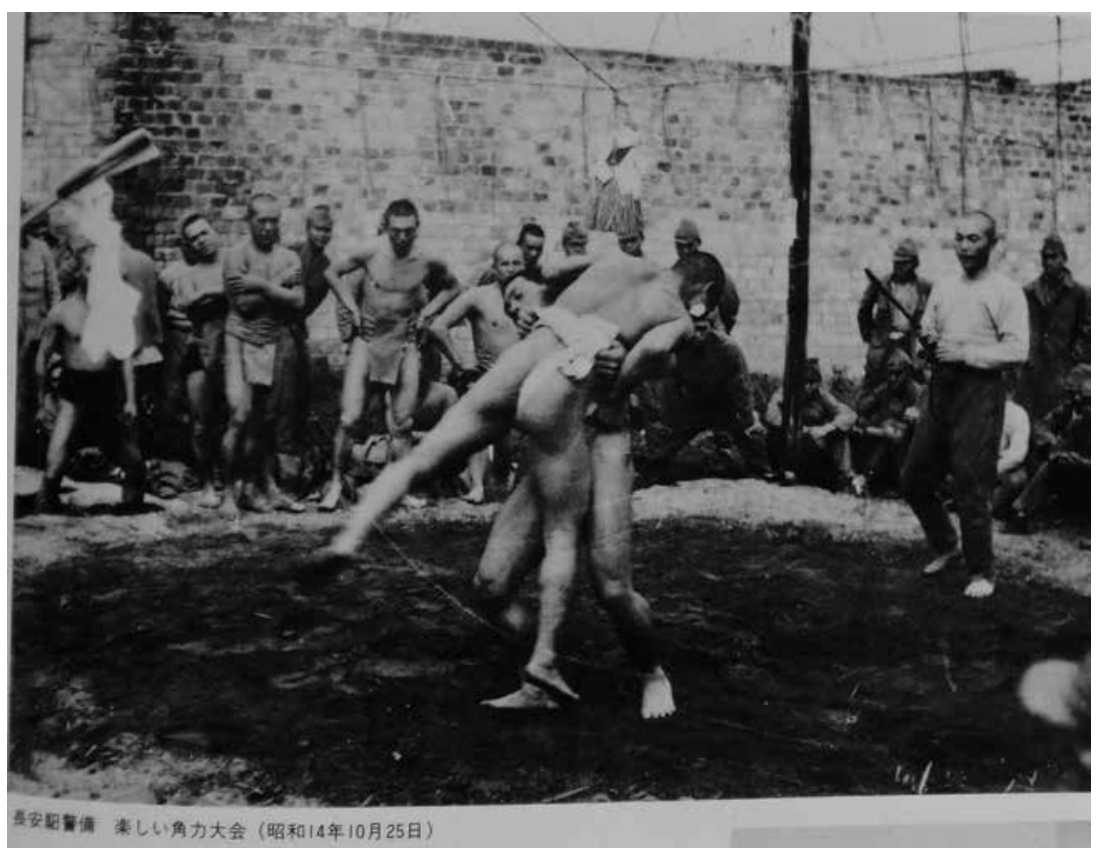

Takashi Hiramatsu 
Figure 5 Going away good luck flag signed by family and friends to brother of Naomasa Kodama (児玉尚正) as he left for the front

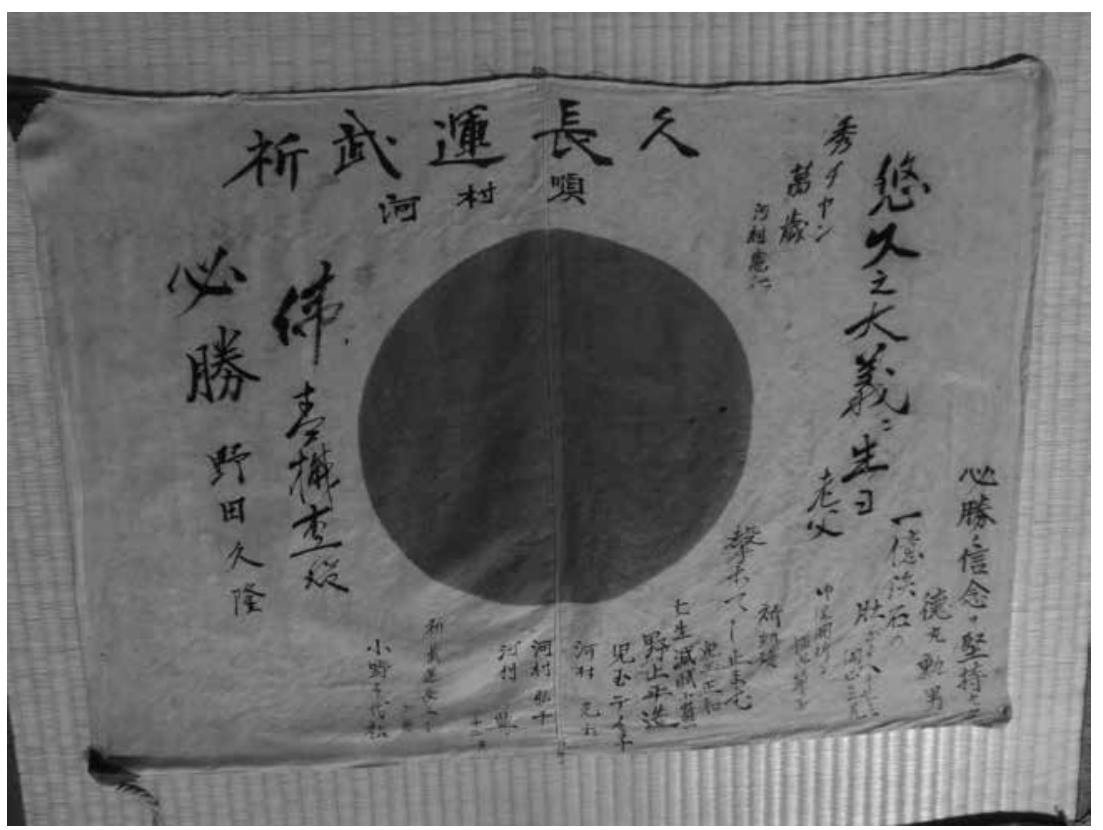

Ran Ying Porter 
Figure 61000 stitch belt [senninbari] made by women for soldiers going to the front for safe return. On display in Yokaren Museum (予科練資料館), Oita City.

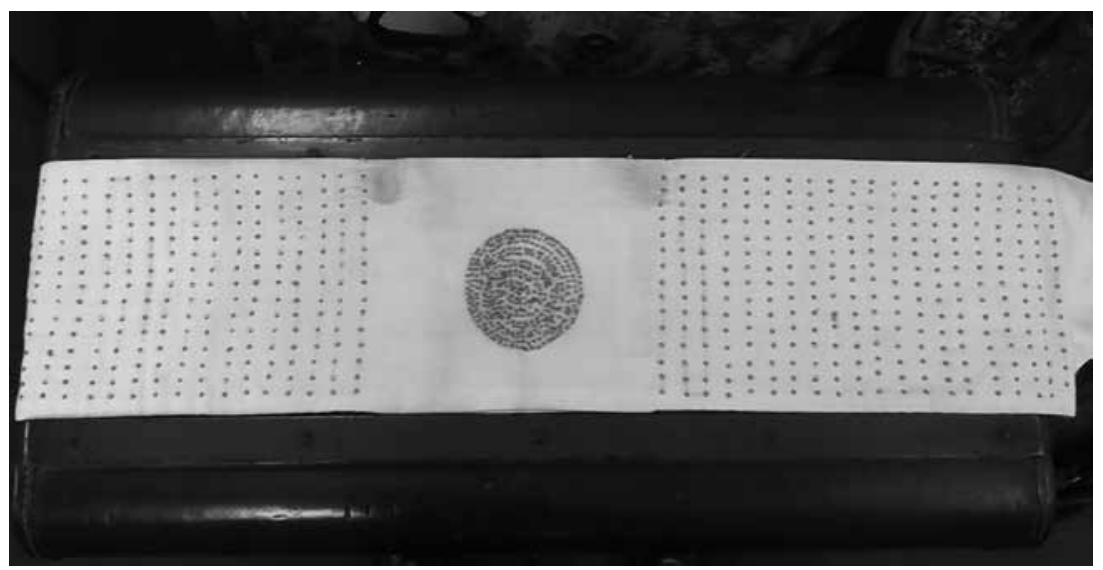

Edgar A. Porter 
Figure 7 Drawing depicting Japanese bombers shooting down Chinese planes by high school student Hideo Sonoda (園田英雄)

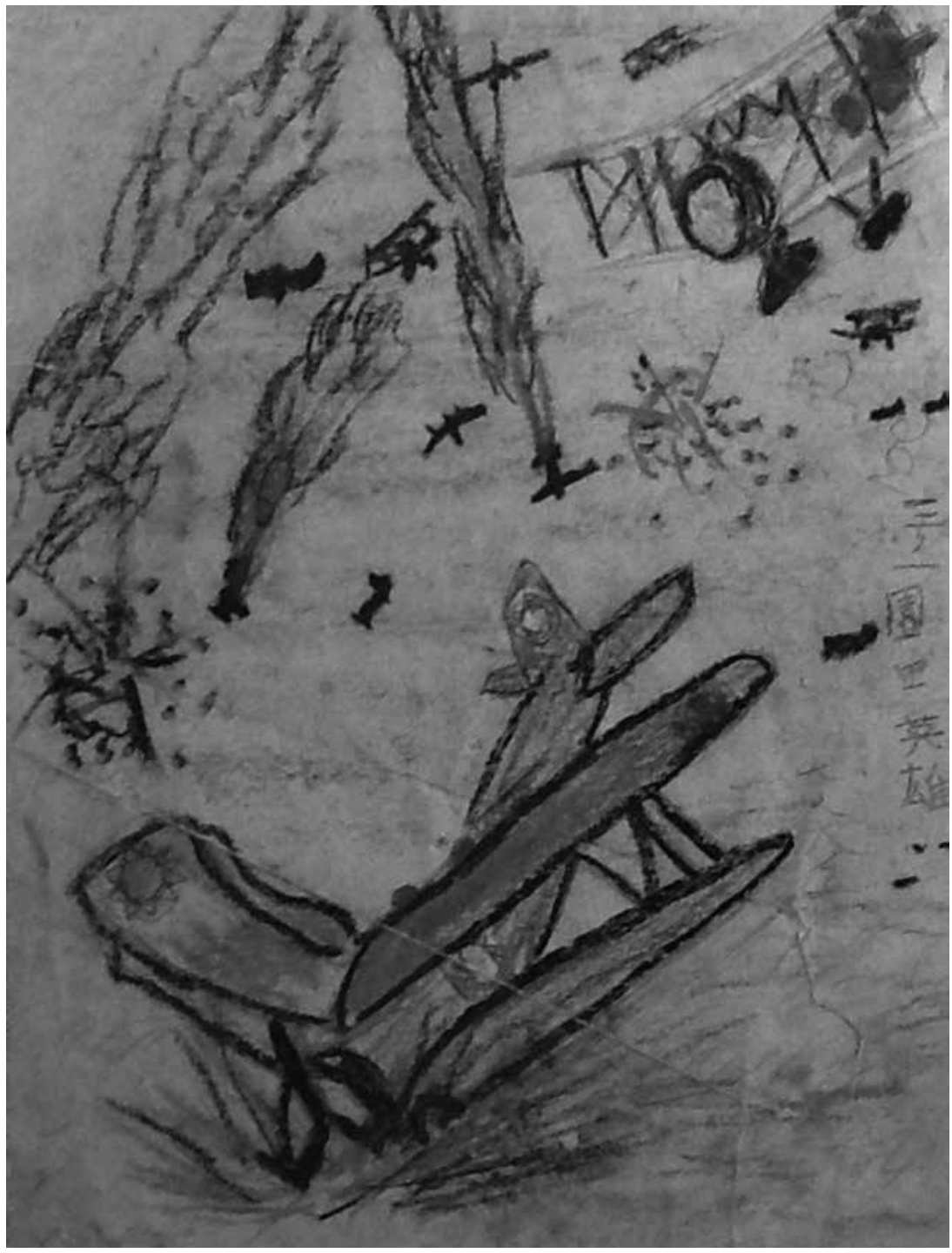

Hideo Sonada 
Figure 8 Navel Cadet telegraph operator Jiro Nakano(中野次郎) prior to departure for the front

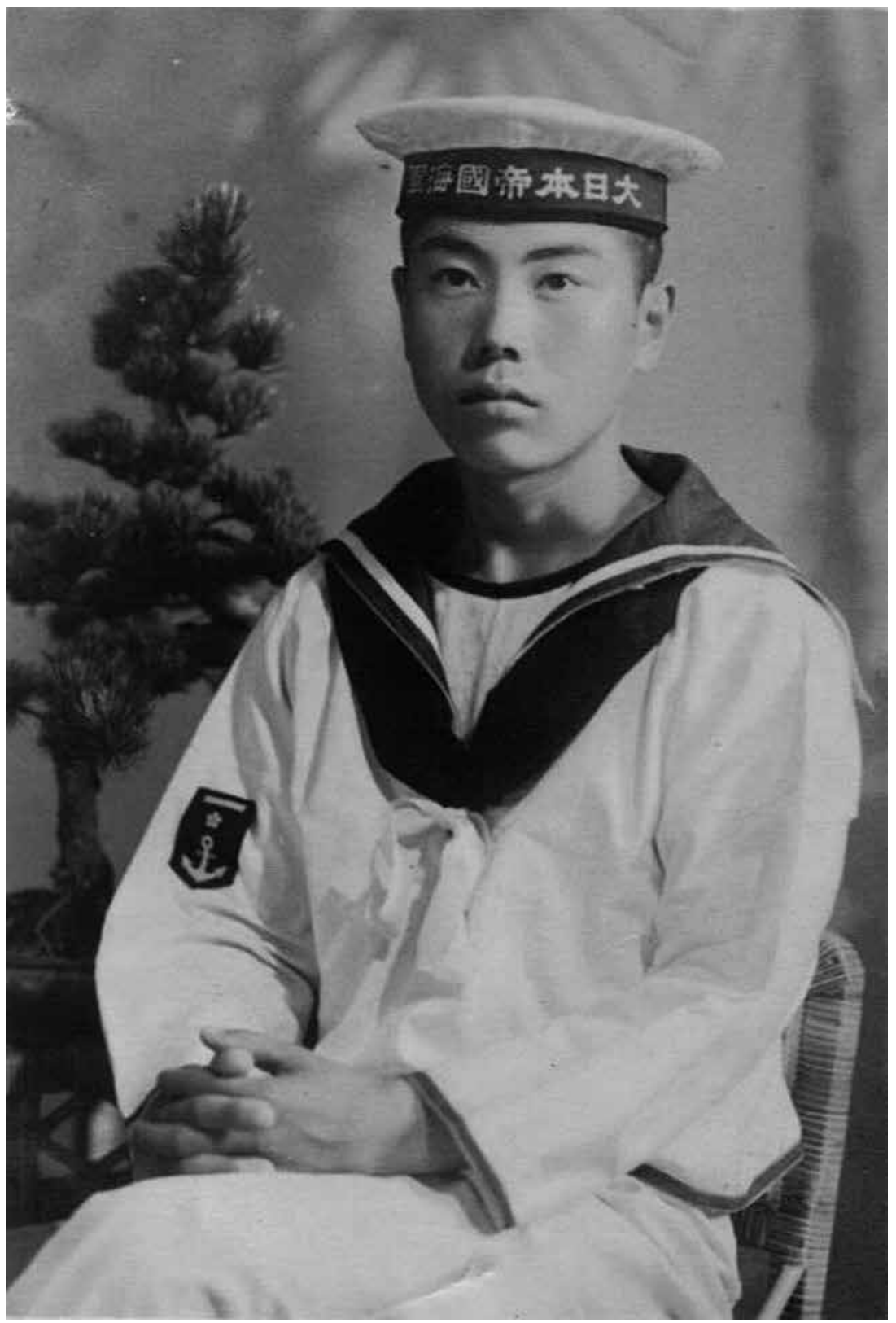

Jiro Nakano 
Figure 9 Admiral Kazushige Ugaki (宇垣一成) just before leading last Kamikaze raid one day after Emperor announced end of the war

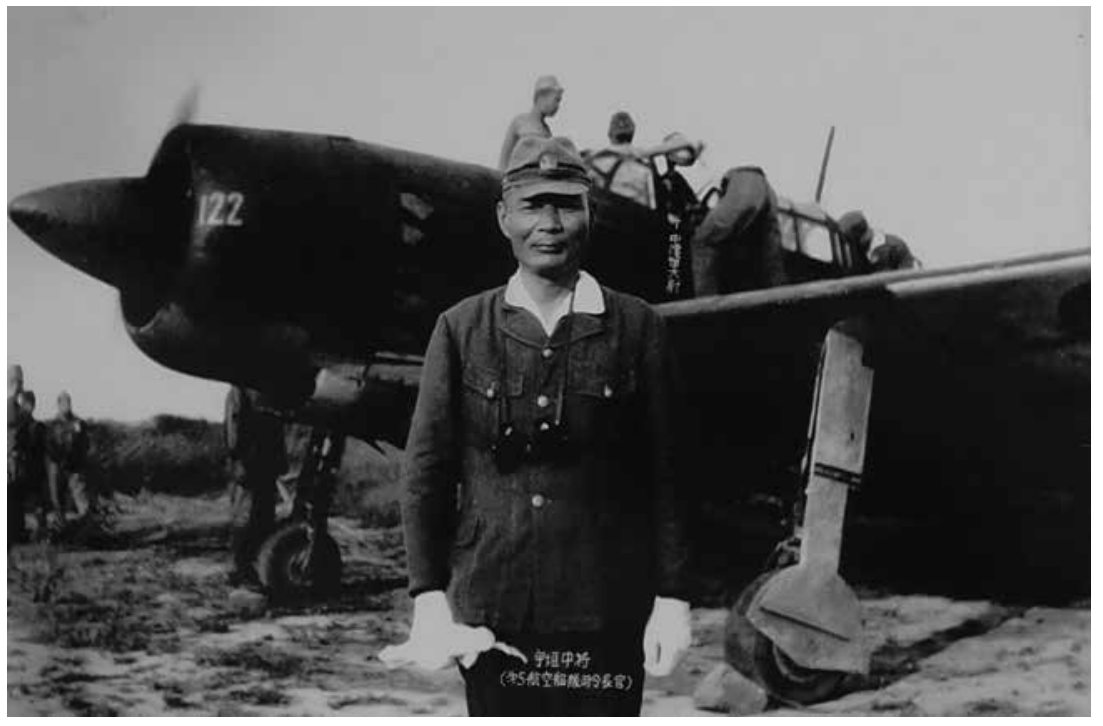

Oita Gokoku Shinto Shrine 
Figure 10 After 70 years, siren to warn of American air attacks in Beppu still in place

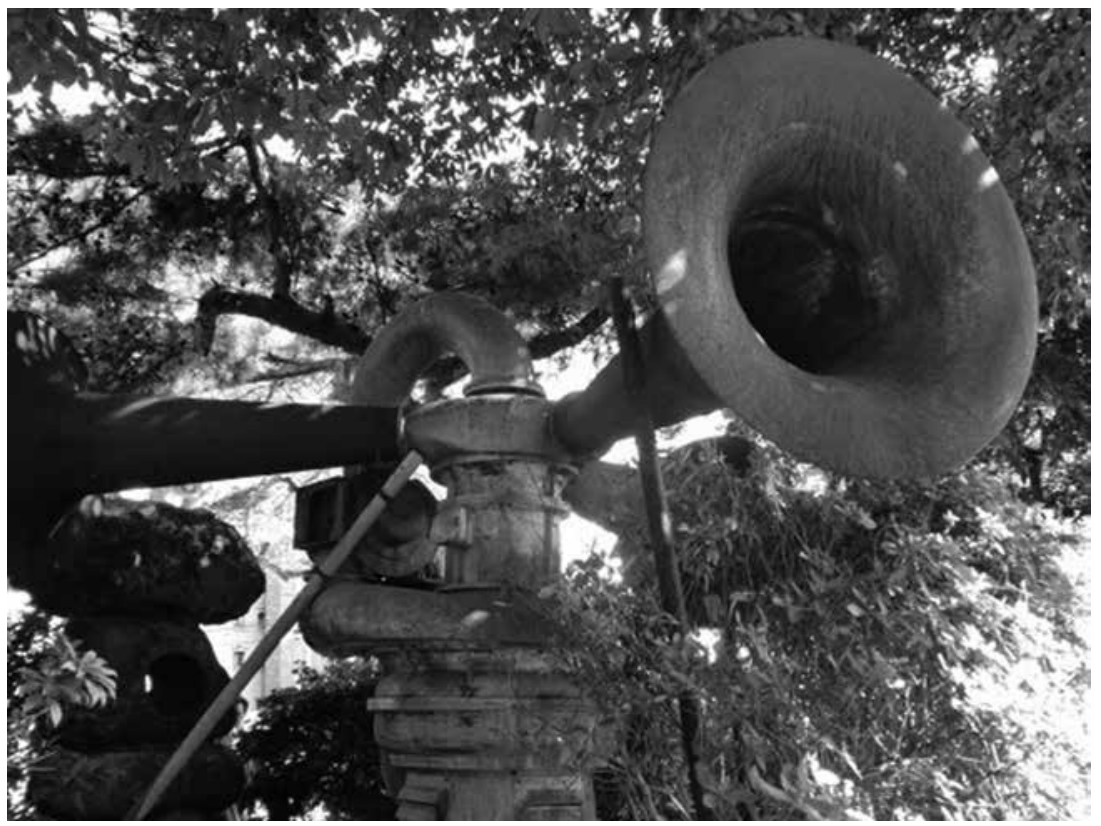

Ran Ying Porter 
Figure 11 Nurse Yukie Matsumoto (松本幸恵), front row, $6^{\text {th }}$ from left, strains to hear Emperor Hirohito during his tour Oita Prefecture, June, 1949

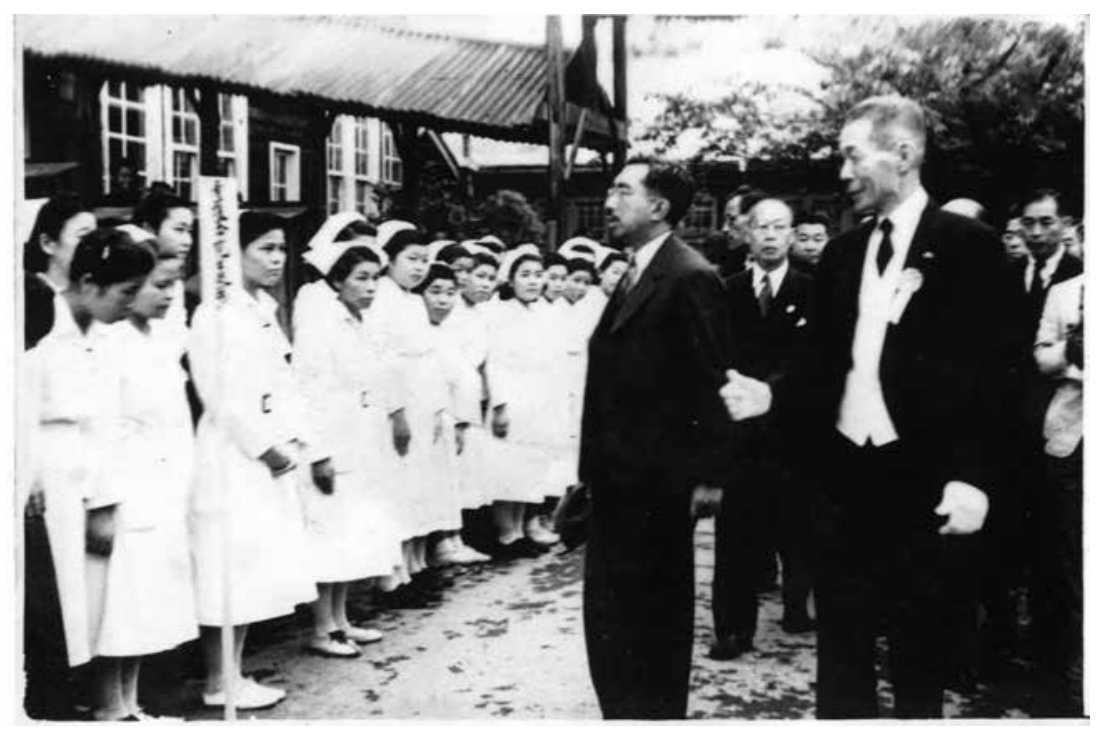

Yukie Matsumoto 
Figure 12 Letter from American Officer apologizing for conduct of American soldiers in Beppu brothels during Occupation

It has just been brought to my attention that Military Policemen under

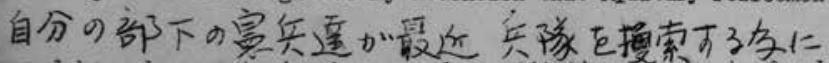

my command have been entering houses of prostitution IIl search of soldiers

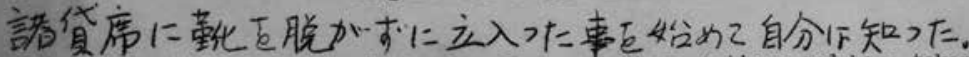
il thout first removing their boots. I regret theso actions and have taken

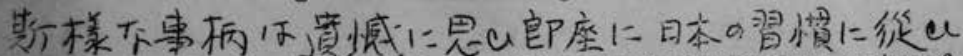
innediate action to insure strict compliance with the Japanese custom of

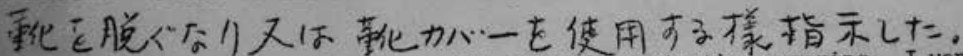
romoving shoes or covering them with suitable protectiva covering. I want

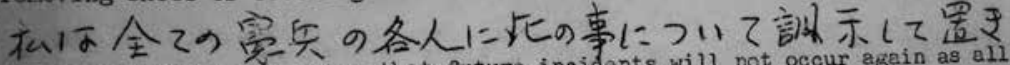
to assure each house owner that future incidents will not occur again as all

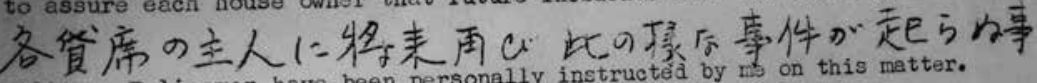
Military Folicemen have been personally instructed by no this natter.

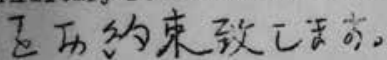

$$
\begin{aligned}
& \mid s / \text { Charles W. Hill } \\
& / t / \text { CHARLSS w. HILL } \\
& \text { Capt MPC } \\
& \text { Provost Marshal }
\end{aligned}
$$

Beppu City Library Archives 
Figure 13 Memorial to high school students killed by American bombs while working in Oita munitions factory. Those students who survived later raised money to place this at Oita High School.

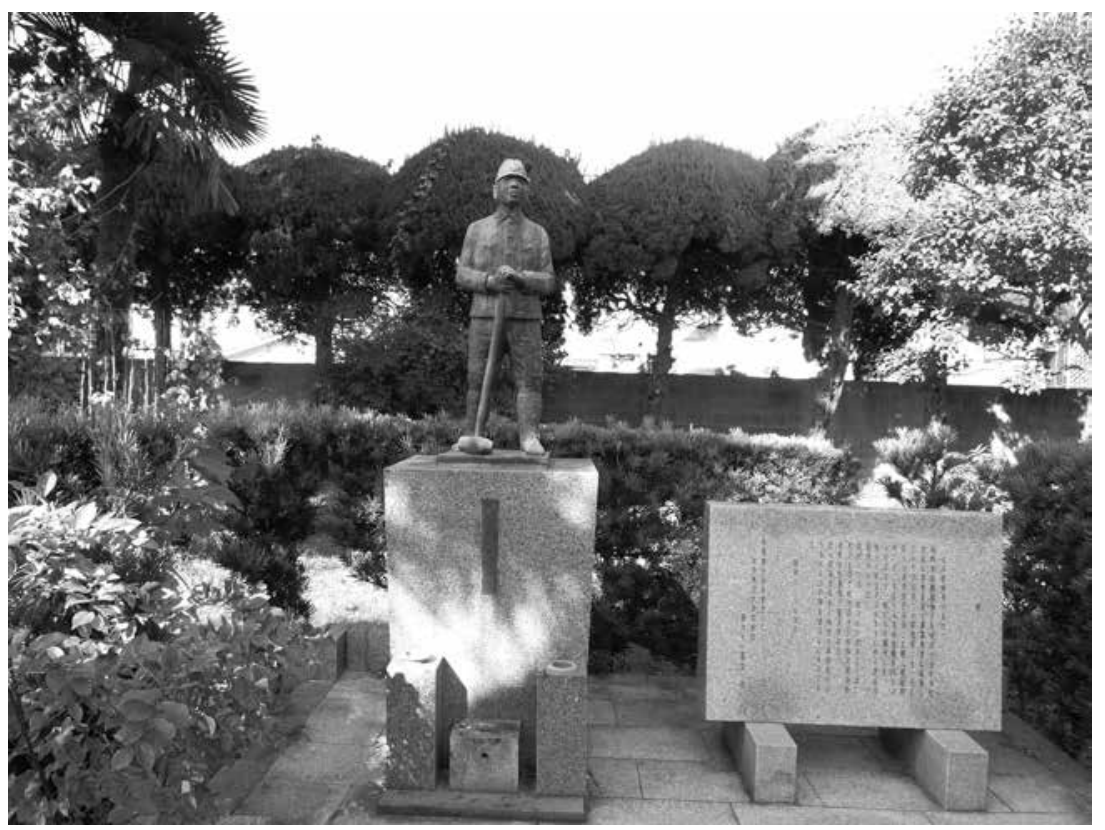

Edgar A. Porter 
Figure 14 Statue of widow and children mourning the death of their husband and father at Gokoku Shinto Shrine (護国神社) in Oita

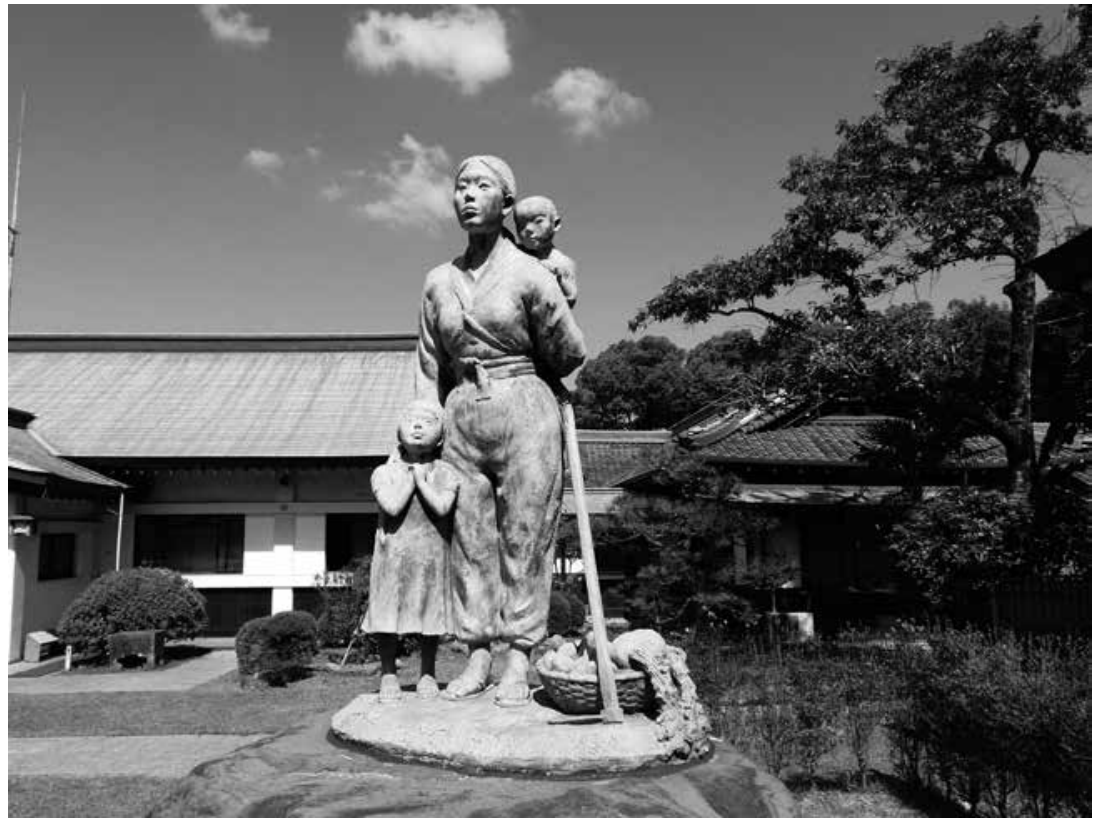

Edgar A. Porter 
Figure 15 Memorial in Takeda(竹田) placed by owner of farm to honor the American airmen shot down and tortured and the Japanese pilot who brought them down

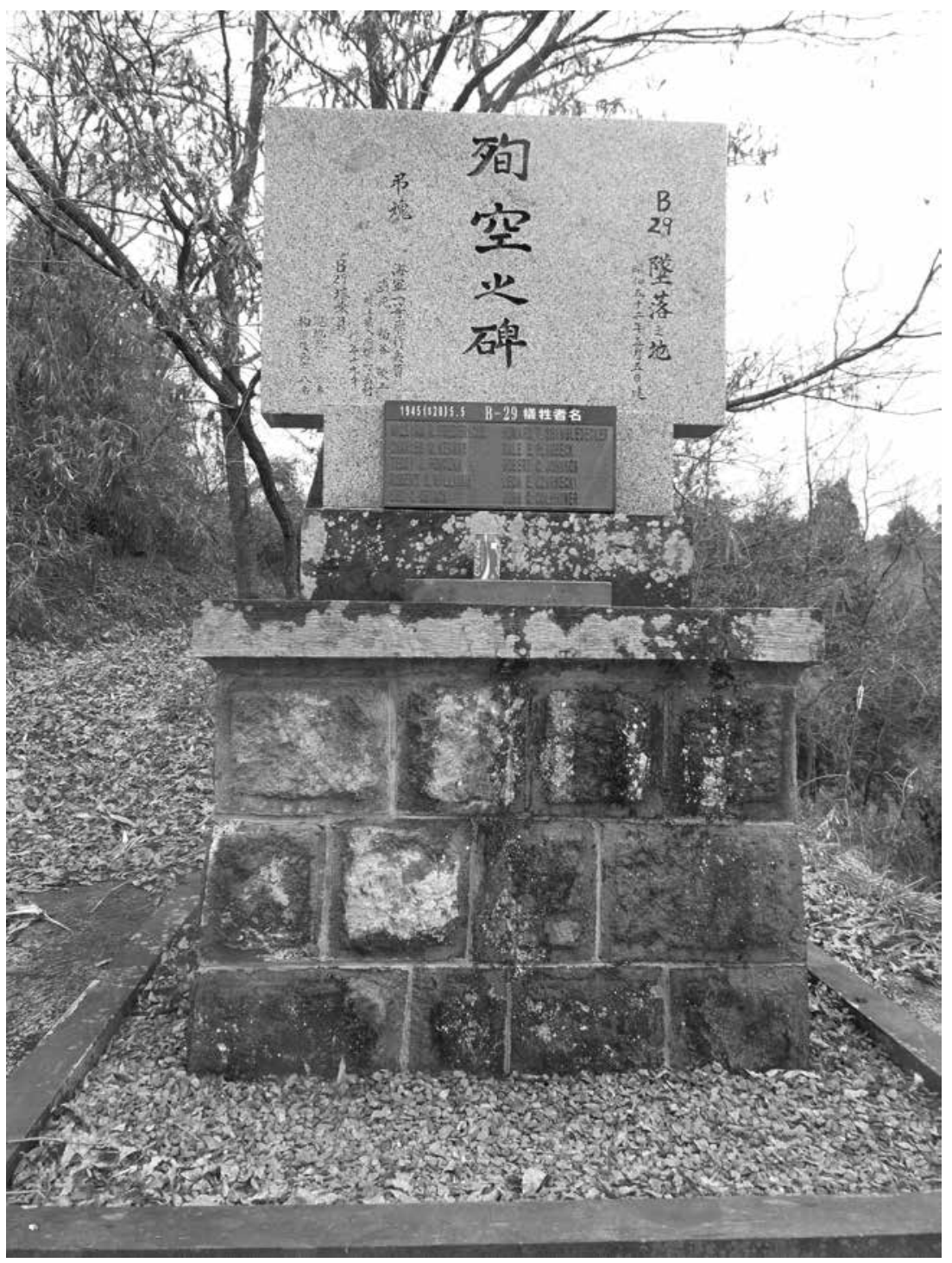

Ran Ying Porter 
Figure 16 Beppu Park plaque denoting site of American occupation Camp Chickamauga

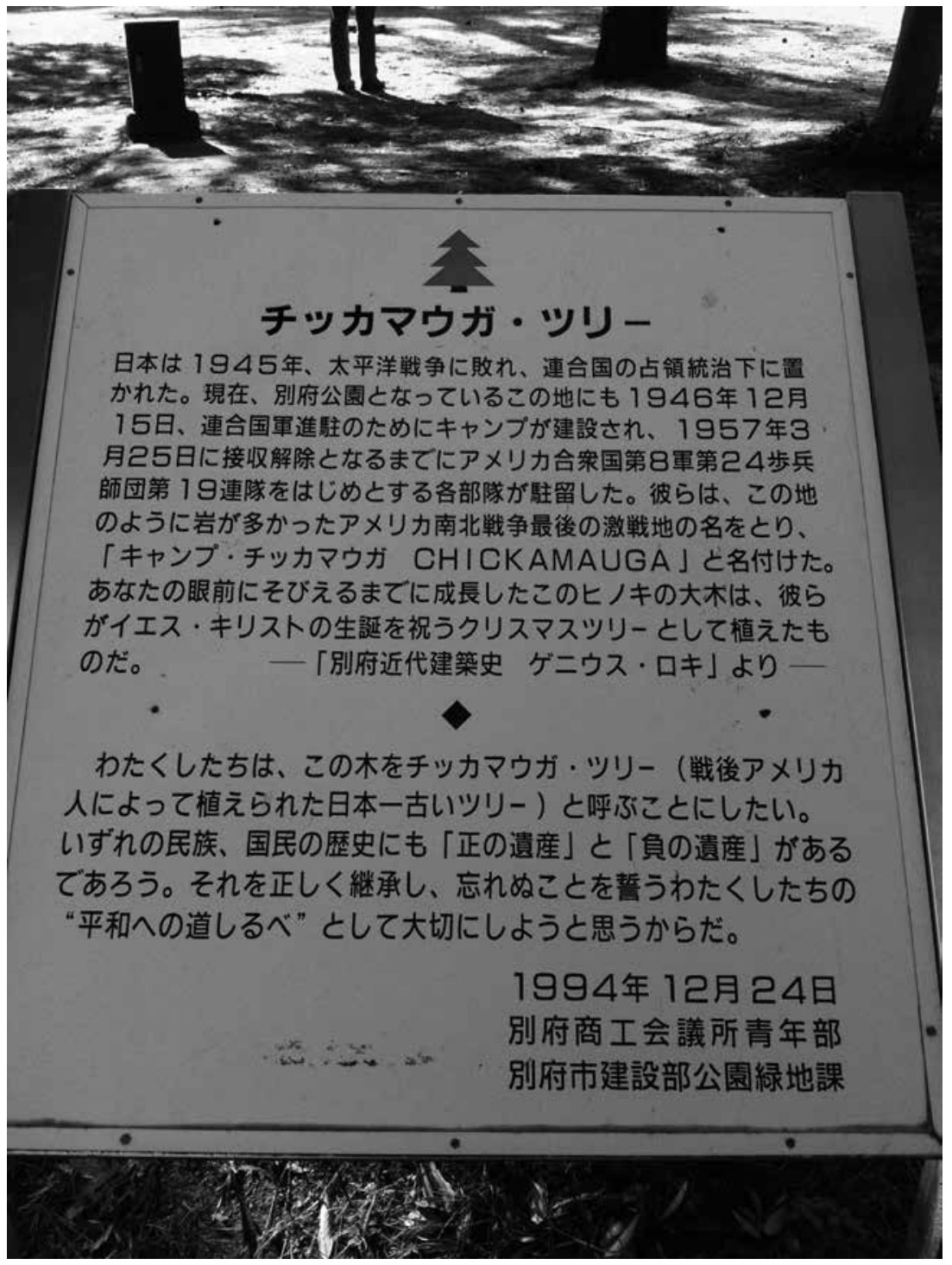

Ran Ying Porter 
Figure 1799 year old Masako Ono (大野政子) surrounded by family and friends during interview

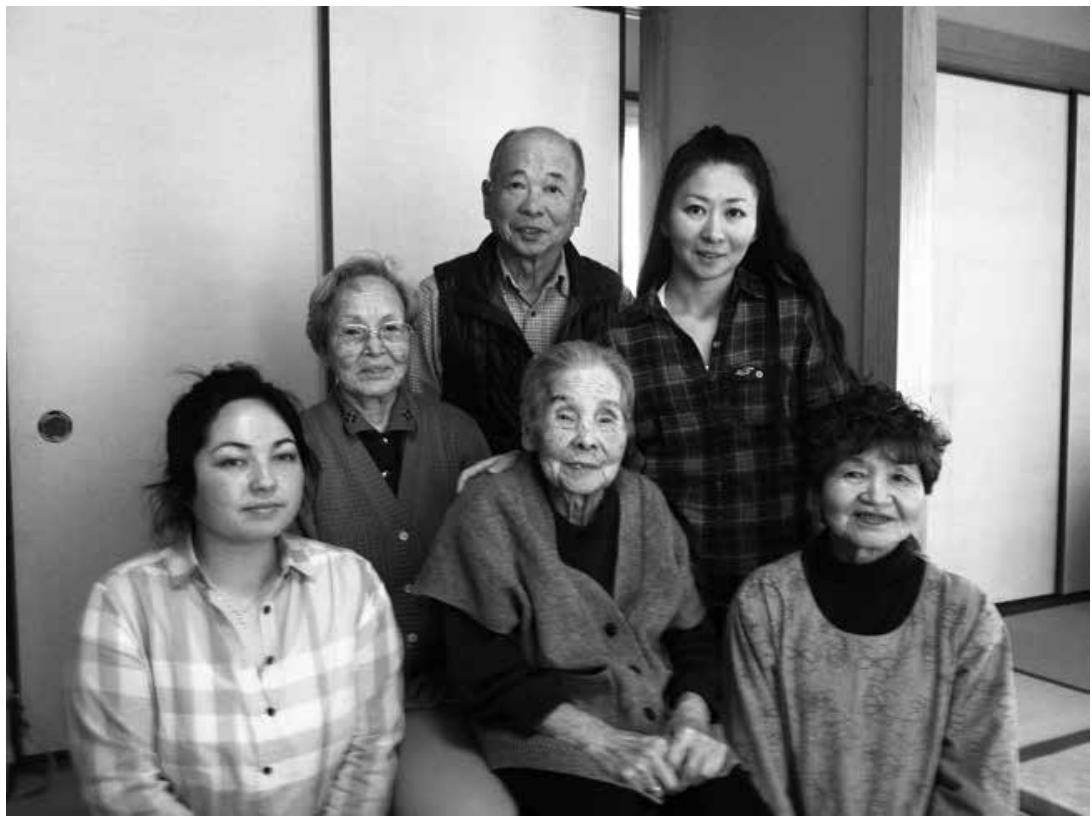

Ran Ying Porter 
Figure 18 Ichiro Hashimoto (橋本一郎) with model Zero he constructed. He repaired damaged Zeros in Oita military factory during the war as a high school student and never lost his attachment to the plane.

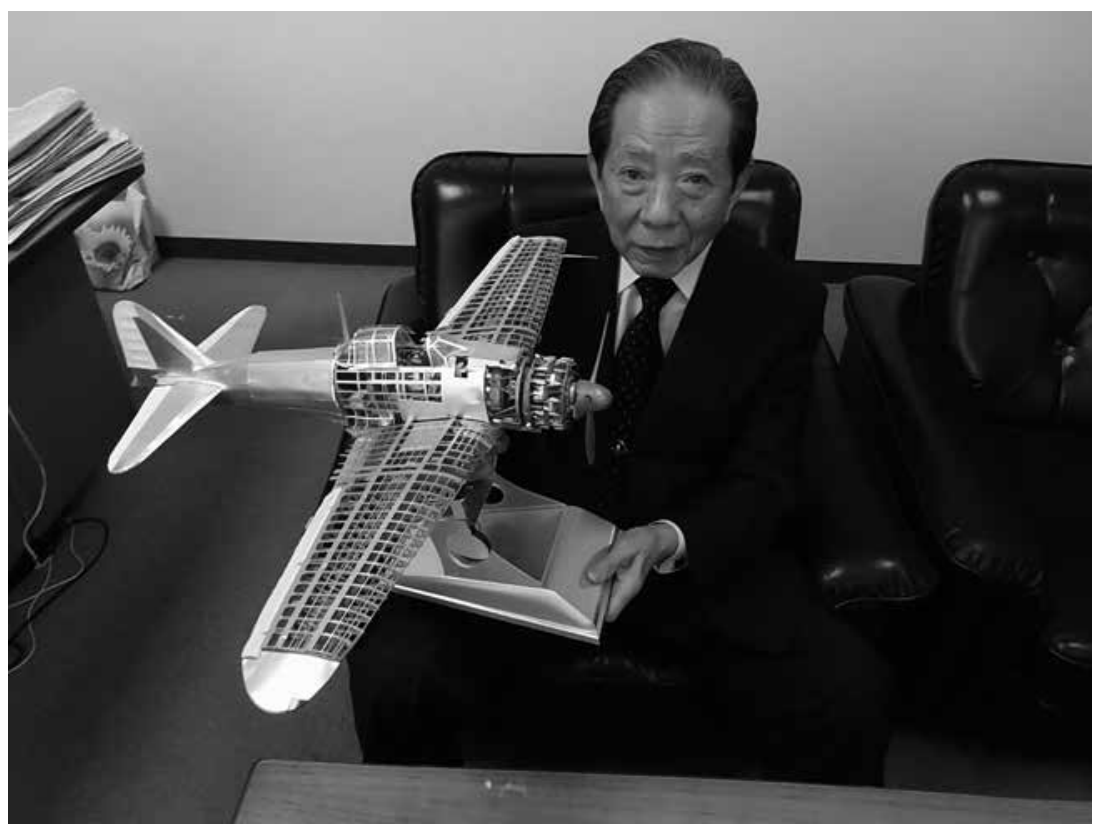

Edgar A. Porter 


\section{$7 \quad$ "I Shall Die with Pleasure"}

\section{Edgar's Encounter with the Kamikaze Boy}

It is time here to relate a personal encounter that took place early in the formation of this story. It involves the moment I met the kamikaze boy who spoke to me, and who impacted the direction of this story in a way I never expected, or desired. Frankly, we were not interested in the kamikaze story. So many tales, so many poems, so many deaths and so many memories had been recounted, so this was not the story to tell. It took place during a visit to a museum in Usa, where a temporary World War II retrospective organized by a local historical association filled the top floor. I had gone to Usa for one of my first interviews, but my host insisted that I first see the display. That would, of course, be helpful in telling this story, so I accompanied him to the display. There were photos of American B-29 attacks on Usa, of Japanese airplanes and shell casings from unexploded bombs. There were pictures of schoolchildren during the war. As we walked around the display I learned that Usa was an active training base and departure site for Special Attack Squadrons, called Tokkotai in Japan but better known in the West as kamikaze. Surprised, but not terribly interested, we then drifted toward a display filled with photos - photos of children dressed in flight gear. These, I was told, were the kamikaze pilots. I could not move from that spot, as I studied the faces of these pilots. How could this be, these were only children? My eyes drifted from one face to another. They stopped when one of the boys stared back at me. He would not take his gaze away, nor could I. He looked younger than freshmen students at my university just a few miles away. He had a smile, a confident face that I see on my students' faces when they are relaxed, when they are content with their lives, when they show pride in their achievements. He could have been my student, or even more disturbing, my son. I thought of my three boys as I watched this boy, remembering their carefree, optimistic teenage years. I looked around to other photos, and they were all the same; these children of seventeen, eighteen, and nineteen years old, about to fly off to certain death within hours or days of the photo. I returned my gaze to the one young man, drawn softly but magnetically to him, to his face and to his voice. Quietly, with the beauty and innocence of youth, he spoke. He asked me not to forget him and his friends when I told this story. I felt the chill of a special moment and could not move. And I told him not to worry, that he and his young comrades would not be left out. That would be 
impossible now. Leaving the museum that day on the way to the interview, I knew there would be more to the story of the war in this small part of Japan than I ever imagined, for all the stories are connected in ways that unfold only as you spend time with those still here and those gone. While some young students from surrounding high schools labored to repair the landing strips again and again, other young people from towns scattered around Oita Prefecture prepared to die attacking American ships around Okinawa as proud members of the Special Attack Force, or kamikaze. So some of their stories must be told.

\section{Oita's Kamikaze}

Throughout Oita Prefecture, the families of 25 young men eventually mourned the deaths of their sons as they flew their planes head-on into enemy ships or crashed into the sea attempting to do so. A few trained but never flew. One Oita boy who survived the war was Kiichi Kawano, a nineteen-year-old kamikaze pilot scheduled to take off on August 16, the day after Japan capitulated. He remembers the day of his assignment as kamikaze and the training he and the other pilots received as they prepared for their suicide mission.

I was trained as a naval pilot training for regular attacks. By 1945, it became more and more apparent that Japan wasn't doing well, and we could no longer keep up with the regular maintenance of the planes. On July 25, 1945, the top military leaders decided to convert my unit of 116 pilots to a Special Attack Force (kamikaze), because our planes were unfit for combat. The planes wouldn't need to be in tiptop fighting condition for obvious reasons. When the order came, I wasn't terrified; however, I did realize that my time to die had come. I had entered the navy at sixteen, expecting to die sometime. But it wasn't until I was assigned to this unit that death finally became a reality. I didn't tell my family about this assignment. I just couldn't bring myself to do it. After all, if I died, they'd be notified. And they wouldn't be surprised, because, at that time, all parents expected their sons in the military to die for their country. This new assignment brought drastic changes in our training routines. During regular training, the pilots must learn to handle different functions and aspects of an airplane. The kamikaze training, by contrast, was simpler but more dangerous. We'd fly up to 2,00o meters then dive down at 45-degree angle. At about 500 meters we'd pull out of the dive. 
This drill was repeated every day, each session taking about 30 minutes to complete. Of the 116 pilots in my unit, 39 of my friends died over the next few weeks. ${ }^{1}$

Not all kamikaze were ordered to join these suicide missions. Some volunteered. Captain Yunokawa, the naval officer whose crew was shot up in Usa before they could take off for Okinawa in March 1945, tells how he joined.

From mid-August 1944, soon after we lost the Battle of the Marianas, it became evident to most of us at my rank that we couldn't win the war by conventional means. So a kamikaze program was formulated, and a call for volunteers was sent out. At the time, the flight team I commanded was scheduled to go and fight the Americans, but we had little confidence that we'd come out on top. We had run a simulation just before the Battle of the Marianas, and the exact thing had happened during the simulation that happened in the real battle. I may have been one of the first to know that there was no way we could win the war by conventional methods, and I thought this was because our pilots were not trained as well as the American pilots. In addition, there were also mechanical failures. For example, once during a training session, I had to perform a crash landing when my fuel tank gauge malfunctioned and I didn't know I had run out of gas. I almost became blind during the crash; as a result, I no longer qualified to fly combat attacks. When the call for Special Attack Force volunteers came, I jumped at the opportunity, as I believed that this might be one way we could still win the war. Besides, it gave me the chance to keep flying. This was two months prior to the first kamikaze attacks in the Philippines. The volunteers were informed that if we joined, we would not survive. So if one wanted to continue fighting as a regular fighter pilot, he was allowed to back out. The volunteers were given one day to think it over. The next day, each must sign the paper stating his willingness to become kamikaze or else drop out. When it came time to sign the paper, many pilots backed out. I, however, cut my finger and marked my paper in blood to show just how determined I was to become a kamikaze. I believed that if I could deal one last, damaging attack on the enemy, my life would be well spent.

1 Oita, Kawano Museum, Oita Prefecture, Japan, May 25, 2012. In his later years Kawano-san constructed a private museum in his home to honor those kamikaze with whom he served. The interview took place there. 
The first Oita kamikaze to crash into an American ship was $2^{\text {nd }}$ Lieutenant Shiro Watanabe of Kitsuki. On October 24, 1944, he flew in the first kamikaze attack of the war, diving his plane into an American transport ship at the Bay of Leyte, Philippines. In part, he had told friends, this was to honor his brother, who had been killed earlier in the war. Before leaving on his mission, he contacted his parents to receive final approval for his decision:

Father, I shall go forward and engage the enemy with our air defense for the Empire of Japan. Thank you for giving me your blessing to go forward! I'll go straight on and do my best for the fatherland. I'll work hard, doing my brother's share, as well.

Mother, if you ask me to stay in the homeland, it might be possible. What do you want me to do?

Her response was "Shiro, I have donated you to the homeland. Do whatever you think best."

A story in the January 2, 1945, Oita Godo Press extolled Shiro Watanabe's offering to his country. The people of his hometown of Kitsuki knew of his sacrifice, the newspaper reported, and were unified in praying, "Blow hard, kamikaze! Never stop blowing, kamikaze." ${ }^{2}$ Community leaders held him up as a role model for others. One retired military commander said,

We have no words to express appreciation when we know those youngsters like Shiro are carrying this great war on their own shoulders. A new and mighty age is coming. Admiral Toyoda tells us that commanding officers alone cannot win this war; we also need stronger home front defense. [Toyoda, supreme commander of the navy, was a Kitsuki native and took particular pride in the action of this first kamikaze.] Although I never met Shiro, I can imagine how he was endowed with great leadership ability after hearing many statements from his mother and others. We need to do our best to defend the homeland with such determination as shown by Shiro. ${ }^{3}$

Others from Oita were soon to follow. Here are just a few:

Yasumasa Majima, from the ancient Buddhist town of Usuki, flew out on April 2, just as the American forces were landing on Okinawa.

2 The meaning of the word kamikaze is "divine wind."

3 Oita Godo Press, January 2, 1945, p. 2. 
Yoshiro Nekohashi from Oita City, age 22, departed for Okinawa on April 9. He left the following poem for his parents:

We are the Kamikaze Corps

That the emperor recognizes

Graciously this is an honor

We will leave a great name, the shinbu, after death Second Lieutenant Jun Minomiya of Oita City, at 18 already designated an officer, died on April 16 over Okinawan waters. In a letter to his parents, he wrote this simple note, "Suddenly I write my farewell letter here. Thank you for taking care of me. I want to do my best to attack a U.S. battleship." Second Lieutenant Tetsuichi Nakamura of the small coastal town of Tsukumi flew out on April 22. He left a similar, hastily written note for his parents, "Eagerly attack with strong will to sink a U.S. warship." Captain Hidehiko Nakajima, a 20-year-old from Nakatsu on the northernmost border of Oita Prefecture, attacked American forces on June 8, leaving this note to his family. "Even if I die, I will strike seven times more for my country."

Second Lieutenant Shoichi Nakajima of Beppu died on May 19. He was eighteen years old. There is no record of a note to his family.

Newspapers across the country glorified the kamikaze pilots throughout the last months of the war, in some cases showing how everyone pulled together to make their missions a success. The local Oita newspaper of March 19 showed a photo of young girls working in a factory as they repaired the wings of planes to be used by the kamikaze. The caption read, "Members of the Girl Volunteers with Kamikaze Headband Valiantly Working on Airplane Wings." ${ }^{4}$

The May 14 edition of Oita Godo Press glorified these young fighters and printed a letter written by Airman $1{ }^{\text {st }}$ Class Hiroshi Obata:

My dear mother and family members, I hope you have been doing well. Being given the most honorable order that I have long awaited, I will finally go on an attack tomorrow. I am overwhelmed by deep emotion. I am happy to be born in this country and to have such parents as you. I am more than ready to attack and completely destroy the brutal enemy, who are repeatedly dropping so many bombs over our territory in order to invade the Land of God, despite the great effort given by our brave counterattacks. Please be at ease because I am now fully confident I 
can do my duty thanks to the instructions given by my superior officers and my own experience. I will never disgrace the tradition of our family line. In conclusion, I wish my mother and other family members to stay healthy. I shall die with pleasure. ${ }^{5}$

Yoshito Ikenaga was twelve years old during the last year of the war, but his older brother left their home in Oita to join the fight.

My oldest brother went to Yokaren School in Yamaguchi to become a pilot. He was seventeen or eighteen at the time and he quickly volunteered as a kamikaze. It was his own decision, and he didn't talk to our parents about it, even though they'd never have opposed it. If anything, they would have been honored. Just before he was scheduled to go on his mission he got seriously ill and came home to the Naval Hospital in Beppu, and he never was fit to return. It was then he told my parents that he was kamikaze. I'm sure my parents were happy to have him home, though when he got there they told him, "Too bad you couldn't carry out your mission." At the time, it was all about the country, so if he succeeded in carrying out his mission, it would have been honorable for him and for my parents. To train as a kamikaze was considered to be the highest honor. It might have been the last time parents would see their children, but they would still wave good-byes proudly. It is unimaginable now, but that was a different era.

It was not only kamikaze from the air that the Japan sent against the Americans. As desperation set in, military leaders looked for any advantage they could conjure up. As the kamikaze pilots had indeed made some headway in at least intimidating the American forces coming close to the Japanese homeland, a new midget submarine was devised to attack from below. In April 1945, in Ooga Village, between Hiji and Usa in Oita Prefecture, a kaiten human torpedo training center was opened on Beppu Bay with a crew of 2,000 men, including submarine pilots and maintenance personnel. At the same time, the Ooga Kaiten Shrine was opened for the spiritual needs of these new kamikaze seamen and the supporting villagers. The first kaiten units were established in 1944 in Yamaguchi Prefecture, and this Ooga unit would be the last kaiten base set up before the end of the war. Men trained to steer regular torpedoes, which were fitted so that one man could guide the torpedo singlehandedly into the hull of an enemy ship. They were to be 
launched from a mother submarine, then quickly head for the target. The spirit of those who joined this suicidal and ultimately fruitless venture is shown starkly in the corps song:

Eternal and indestructible Japan

Someone must save her in time of crisis

Young, loyal, and strong

Kaiten Corps with hot blood surging

Their reputation pure before the gods

Learned from the spirit of Kusunoki Masashige

Comrades now go smilingly

Kaiten Corps with matchless honor

\section{Born seven times}

Sinking giant ships, certain death

Young cherry blossoms 20 years of age

Kaiten Corps calmly goes to die in battle

Even their waterlogged bodies as a foundation

Believe in spring that heralds

The emperor's prosperity

Ah, Kaiten Corps fiercely righteous

On August 2, 1945, the first eight men departed Ooga and headed to Kochi Prefecture to meet up with the mother ship. Because the war ended before leaving on their mission, none of the men who trained for this action died in combat. The commander of the unit, Hidesuke Matsuo, however, committed suicide at the Ooga base a few days after the end of the war. ${ }^{6}$

6 “Oga Kaiten Shrine, Hiji Town, Oita Prefecture," Kamikaze Images, http://www.kamikazeimages.net/monuments/oga/index.htm. The word kaiten can be translated as "return to the sky" and was the term given these manned torpedoes. In 1981 a small-scale model of the kaiten was put on display next to the still active Oga Kaiten Shrine. The plaque says, in part, "They strongly believed in the indestructibility of Japan and in certain victor for the Empire. They raised the great banner of Kikusui on the clear, beautiful shore and totally devoted themselves with great enthusiasm to training for the kaiten special attack weapon." 


\section{$8 \quad$ Never-ending Sirens}

\section{Cancelling Classes and Evacuating Students}

These incessant kamikaze attacks only heightened American resolve to flatten Japan, with Oita a prime target. From mid-March until the war ended in mid-August, American planes flew along the coast, attacking Oita City, Usa, the Saiki Naval Air Base, and smaller targets along the way. On April 26, the B-29s returned and pounded these targets once again. Twenty-eight died as they ran for their poorly constructed shelters. On May 8 the local newspaper reported inaccurately that eight B-2gs had been shot down over Oita. "Oita prefecture citizens watched our shells explode on the enemy planes and they highly praised our defense forces. Airplane-producing workers were encouraged by these interceptions and gained new energy to produce airplanes as quickly as possible." This was yet another example of attempts to raise morale with fictional stories, many of which were not acknowledged until after the war. ${ }^{1}$

While these attacks dramatically affected the lives of people in Usa, school officials did what they could to maintain some sense of normalcy for their students. But there was now a new normal. Teachers left their positions to join the army, students scraped bark off trees to make uniforms, and bombing attacks killed families, but rice was still planted and classes were sometimes held. The cryptic daily log kept by the principal of the elementary school in Usa describes this new normal. These entries chronicle the time between the beginning of the Japanese school year in April, which coincided with the beginning of the most intense bombing over Oita, and the end of the war in August 1945.

April (two weeks after first bombing of Usa airfield)

$2^{\text {nd }}$ : Goodbye to conscripted soldiers. Goodbye to Tsuda Toyoshi at 6:0o;

goodbye to Tokumitsu Hayashi at 14:30.

$3^{\text {th }}$ : Sirens. Bombing. Students evacuated immediately. 
May

$1^{\text {st: }}$ Sirens. Air raid. Students evacuated.

$15^{\text {th: }}$ Emergency staff meeting to discuss how to educate the students when they cannot come to school. For the time being, teachers will be sent out to the student's homes when classes cannot be met at school as they can come and go more quickly than students.

…...

$3^{0^{\text {th }}}$ : Sirens. After morning assembly, all but first graders strip trees.

June

$1^{\text {st }}$ : Sirens. Air raid. All but $1^{\text {st }}$ and $2^{\text {nd }}$ graders strip trees. National Military Service Ceremony held at 14:0o.

$29^{\text {th: }}$ Sirens.

$30^{\text {th }}$ : Warning. Raid by small planes, send everyone home.

July

$1^{\text {st: }}$ Sirens. Hold regular morning classes. All students sent to work.

$31^{\text {st: }}$ Sirens. Classes end at 10:00.

August

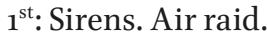

$14^{\text {th }}$ : Sirens. Because of the increased air raids, we have started a new rule for classes. If there is siren by 8:00, students go to their local classroom. If there is an alarm, study at home.

$15^{\text {th }}$ : No sirens, classes held locally. Sirens. Send students home. Government announcement raises questions.

$16^{\text {th }}$ : The principal goes to Yokkaichi to confirm the reports on end of war. Due to the end of the war, classes will be held at school. Classes in morning, clean up and go home after noon.

$24^{\text {th }}$ : Ceremony held from 8:30 to discuss what happens now that war is over. $^{2}$ 


\section{Dodging Bullets and Delivering Babies}

The students in this and surrounding schools carried out their responsibilities, made sacrifices, and experienced the horror of air strikes almost every day during this period. They worked in the fields and forests, and occasionally studied in the relative safety of shrines and temples scattered around the mountains. Food was becoming scarce in the last year of the war. Usa elementary school student Takafumi Yoshimura recalls, "We brought our bento [lunch box] to school every day as usual, but now they were made of wood, not aluminum like before the war. Also, the bento had to be filled with barley not rice. Teachers checked the bento to make sure we only had barley, as all our rice had to be sold to the government." One other Usa boy still in elementary school at the time describes the chaotic scene only days before the end of the war:

Close to the end of the war, I attended Choshu Elementary School. There were hardly any classes as the older kids helped us dig shelters on school grounds. During summer break, sirens would go off all the time, and we had to stay at school day and night. In case the school was bombed, we put out fires to prevent them from spreading.

Once, I was walking across Komatsu Bridge with a protective cloth over my body when, all of a sudden, a Grumman flew toward me. I was right in the middle of the bridge when I heard splashing in the water, and it struck me that he was shooting! He was shooting all around me, and I was sure I was going to die. But I didn't want to die on a bridge so I turned around and started running. I ran the fastest hundred meters ever in my life. Lucky, I found a shelter along the river and dove into it. No one else was there. It took me a while to catch my breath. I came out and continued on my way. As I reached the top of the hill, he started shooting at me again, and I found another shelter with a few tatami mats in it. Just as I thought I was safe, an explosion crumpled the shelter, piling dirt on top of me. When I finally made it home, I was bruised and totally exhausted. ${ }^{3}$

Life on the ground throughout Oita Prefecture became desperate, but the people never quit doing their part to win the war. Tsuruko Tomonari was a nursing student who grew up in Oita and later became a midwife in Beppu. Those days remain clear to her over 60 years later. 
The girls in our neighborhood were organized into groups by older ladies, about 20 to a group. When bombs fell on our homes, some would get stuck on the roof before they exploded (these were the smaller time bombs). To protect the houses, we'd put our aprons on and knock the bombs off the roofs with long rods. We'd also put out fires and build shelters for our neighbors. We weren't scared, because we never thought about them exploding. It is unthinkable now, but that was normal then. We were fortunate that none exploded as we moved them.

Nurse Tomonari's work as a midwife shows the strains on people under the bombing, even if the bombs hit too far away to inflict direct damage.

I came to Beppu to help my aunt who was a midwife. When air raid sirens sounded, we'd evacuate to a shelter we'd built next to the ladies clinic where I worked. The bombing was almost always at night. I would get up each morning, put on my nurse's hat, prepare breakfast and feed the patients, then sterilize our equipment. The midwives lived together in the clinic and we built the shelters ourselves. Even though Beppu was never bombed, it was so close to Oita City, we didn't know if it would be next. The shelter was very small, just big enough for a few people to stand in. Initially, there were $3^{8}$ midwives in our group, but most left the area when the bombing started. Only three of us stayed until the war was over. Some of the doctors also left. During Oita bombings we used to take the women from the hospital to the shelter to give birth. Since the shelter was too small, we couldn't fit them all in there, so those not yet ready to give birth were left in the clinic alone during the bombing. It was very difficult to assist a birth underground, because dirt was all over the place and falling from above, as well. To make it worse, we had no hot water or proper equipment in the shelter. All these things had to be left in the hospital when we rushed the women to the shelter. It was impossible to keep anything sterile, so infection was a constant problem. Even in the clinic, we had little in the way of sanitary equipment; no gauze, bandages, or clean needles. We washed and rewashed the gauze. I guess all the supplies went to the soldiers. All births had to be natural. We couldn't perform C-sections because we didn't have enough tools or any way to sterilize and clean what we had. There were times we just couldn't do anything to help the mothers or the babies when complications arose. We just waited for them to die. When babies were delivered in the shelter, we cut the cord there. For every thing else we waited until we got back to the clinic. After the mother and baby went home, they were mostly left on 
their own because we were too shorthanded to provide them with any regular check-up. Fortunately, most babies were delivered healthy, and because the bombing was not directly on Beppu, the hospital facilities were intact, so we could usually finish the delivery and return to the hospital when the sirens stopped. Each air raid lasted about one hour.

Despite the sirens and bombings, students, like the nurses, continued their work by modifying their production plans to meet new challenges. Like the clinics, some factories relocated. Ichiro Hashimoto, assigned to a factory making airplane engines from February 1945 until the end of the war, recalls:

As the raids got worse toward the end of the war, some of the smaller factories like mine were moved outside the city to escape the bombing. Big tunnels were dug into the sides of mountains and we moved into those to do our work. Our tunnel was huge, and we would make the engines there. Plane engines at that time were not so big, so we kept up the pace. As young students we had no experience or training to perform such specialized work, but we worked feverishly under the instruction of professional engineers. 


\section{$9 \quad$ A Hard Price to Pay}

\section{Child Scouts}

Despite frequent optimistic reports of victories and encouragement from Japanese officials, the air attacks continued throughout Oita during the long battle for Okinawa, and the bitterness of the common citizen against the American enemy grew day by day. The children grew more independent and performed their duties with a mixture of playfulness and grown-up responsibilities.

Until the day Japan surrendered, we were repeatedly attacked, and anything in sight burned to the ground. It was a horrifying genocide. When the Americans began raping the Oita skies, I was a second-year elementary student and lived in the center of Oita City. Whenever air raid alarms sounded, people would all run to a shared bomb shelter. The shelter wasn't all that big and was dark and humid. It wasn't a comfortable place for a kid. Some of the children, including me, would sneak out to the nearby bamboo forest; in fact, some older fifth- and sixth-grade boys had built a secret hideout of their own there. They also made their own "watchtower." They wanted to be the first to spot the enemy planes, so they could warn the adults. It might have been their dedication that made them do this; it might also have been the rush of excitement they felt when they saw the planes. At the time, the fifth and sixth graders at Hetsugi Elementary School were being trained for military combat. Every morning, they'd spend an hour practicing with bamboo sticks. They sharpened the sticks and practiced stabbing the enemies' throats with it. In any case, as the boys climbed up on their watchtower, they'd be excited as they discussed their plans. But as soon as they heard the bombs in the distance, they'd immediately become silent and look intensely toward the north. Once, a lone Grumman spotted us in the forest, and proceeded to spray us with bullets. You could hear the bullets ripping through the bamboo trees as the older boys rushed to climb down. Fortunately, the bullets only went through the bamboo and didn't hit us. I was young and didn't know better, just stood in the middle of the bamboo field as the bullets whizzed by me. My body shook with fear. Everyone hated the American planes more and more. But our Japanese planes were nowhere to be seen. The people felt abandoned and helpless. ${ }^{1}$ 


\section{Easy Targets}

American carpet, fire, and time-detonated bombs eventually destroyed much of Oita City. The Japanese Army and Navy were steadily losing the fight in Okinawa, and control of the air and waters surrounding mainland Japan was gradually changing hands. There was practically no defense, as Japan no longer had the planes or trained pilots to protect the country. This gave comfort and confidence to the American B-29 airmen, and they felt relatively safe as they headed for their bombing raids over Oita Prefecture. We can see this confidence in the reports of two American pilots. "On March 27 we had our first daylight formation since January 27. It was a milk run. The target was Oita Airfield on Kyushu. Our whole formation saw only seven bursts of flak and no fighters. We bombed visually and hit the target too from $15,000 \mathrm{ft}$. This was our lowest altitude day mission, and I'll take more like it gladly."

A second pilot reports on his mission one month later. "We ran two missions on the $20^{\text {th }}$ and $26^{\text {th }}$ of April to Oita Airfield on Kyushu in support of the Okinawa campaign. I can't recall much about them except that there was little enemy opposition, there being only a few flak guns in the target area. Major Schieber was copilot on one and Major Reilly on the other. Oita is an airfield right on the coast, so the Japs had no opportunity to send up fighters. On the second one, the target was socked in, so we had to bomb by radar individually. These bombings were from 18,0oo feet. The Kyushu strikes are $\mathrm{OK} .{ }^{2}$

Bombing Oita became a high priority for the Americans, especially during the Okinawa campaign. It even earned some pilots special commendations, as seen in this following diary of a B-29 pilot describing an attack on Oita on May 5 .

We were alerted about noon on Thursday May 3 [May 4 in Japan]. They had pre-mission chow for us at 2100 . Briefing was at 2200 and we had to take off at 0100. Major Carpenter rode in the copilot's seat as Command Pilot. We flew at 7100 feet most of the way. Our course doglegged to Iwo Jima and then to our assembly point on the southeastern tip of the Japanese home island of Shikoku.

2 Caleb Dana, "Diary of a Member of the $73^{\text {rd }}$ Bombadment Wing Fliers by Caleb Dana, bombardier, $73^{\text {rd }}$ Bombardment Wing Saipan,Marian Islands, 1944-1945," "Diary of a Member of the $73^{\text {rd }}$ Bombardment Wing Fliers, The First Flyers to Undertake Missions over Japan, by “Caleb," Saipan, Mariana Islands, 1944-1945," http://old-new-orleans.com/Mission_Diary.html. 
Ours was lead plane in the group and we assembled our squadron at 17,500 feet. From there our group flew to the target, the Oita Naval Air Base on the northeastern coast of the island of Kyushu. The bombing run was made at 17,000 feet. The bomb load was twenty general-purpose bombs. Time of "bombs away" was 1006 Friday morning Guam time. WE MADE A GOOD HIT ON TARGET.

Just before and after bomb release time, we had some fighter interception, mostly twin-engine planes. There were 5 to 10 fighters and they made about 8 attacks on our formation. We also saw a couple of bursts of flak. Our formation had eleven planes, as did the $61^{\text {st }}$ and $62^{\text {nd }}$ Squadrons.

We came back singly and landed at Guam with 580 gallons of fuel at 1715 , logging 15 hours, 45 minutes of Form One Time. After interrogation we had a good supper. ${ }^{3}$

For the successful completion of their mission, the crew from this attack on Oita received a Certificate of Commendation from their commanding officer, Colonel Carl R. Storrie. In presenting the commendation, he stated, "The members of this B-29 crew merit the Certificate of Commendation for their contribution to the successful bombing attack of an Oita Airfield. They are herewith presented this certificate and highly commended. Their performance was largely responsible for the accurate bombing of their entire unit and the success of the mission. Their skill, devotion to duty and courage reflect great credit on themselves and their organization, and is the source of pride to this headquarters."

As American airmen received commendations for their bombing raids, the people below moved from bombed-out homes to temporary shelters, buried their dead, and grew more bitter and vengeful over the incessant attacks in Oita. On the very day the May 5 attack commenced over Oita, a rare event occurred, and the bitterness and vengeance found an outlet, if only briefly.

\section{Taking Revenge: B-29 Is Downed}

Schoolchildren were taught to hate their enemy, as were the adults as they followed their newspapers and radio broadcasts. But it was the American

3 “39 $9^{\text {th }}$ Bomb Group (VH) Crew 14: $7^{\text {th }}$ Mission, Oita Airfields," http://39th.org/39th/aerial/6oth/ crew14a.html. The dates in Japan would be one day ahead, thus the attack would have been on May 5 in Japan.

4 Ibid. 
B-29 flyers who were hated the most. They were considered war criminals due to their indiscriminate bombing of civilian targets. Language such as "raping the Oita skies" and "genocide" describes their bitterness toward and fear of American flyers. Such language appears often in the newspapers, diaries, and postwar histories of those who were there. It is no wonder that the rare downing of a B-29 would spread elation among the people. It is also not surprising that if some of the crew survived the crash, their fate was sealed, for civilians expressed their vengeance on any American pilot found alive before turning them over to the military. This treatment of captured pilots was validated by the government with the August 1, 1944, directive, "Kill-All Order" issued by the War Ministry in Tokyo.

When the battle situation becomes urgent, the POWs will be gathered, confined in a designated location and guarded with vigilance until preparations for the final disposition are made. Although the basic aim is to act under superior orders, individual discretion may be used under certain circumstances. Whether they are destroyed individually or in groups, and whether it is accomplished by means of mass bombing, poisonous smoke, poisons, drowning, or decapitation, dispose of them as the situation dictates. The goal is to prevent not even one POW from escaping, to annihilate them all and to leave no trace. ${ }^{5}$

Bringing down one of these massive B-29s was considered nearly impossible. Yet there was one way. And that was to fly directly into the enemy plane ${ }^{6}$ The story of just such a rare incident happened on May 5, 1945, after bombs were dropped near Oita. In this case, the result was particularly horrific.

Akira Tani was a curious twelve-year-old in Beppu in 1945. While Beppu was spared B-29 bombing, it did not mean the people of this hot springs resort town some 15 kilometers from Oita City felt safe. Mr. Tani remembers:

When the air raid siren started, we'd all leave school and go home. We were supposed to join our families in the shelters. But I never went to the shelter. Whenever the sirens went off, I always got up on a persimmon tree at my house and scouted the enemies' movements, announcing to

5 Kill-All Order of August 1, 1944. War Ministry, Tokyo, http://mansell.com/pow_resources/camplists/fukuoka/fuk_01_fukuoka/fukuoka_01/Page05.htm, http://home.comcast. net/ winjerd/Pageo5.htm\#Vivisections. (There are different translations of this order, but all deliver the same message.)

6 Hoashi, p. 74 . 
everyone which way the airplanes were coming and which way they were going. One day after the siren sounded, and I climbed up my tree and saw a Japanese airplane following three B-29s in the sky. Then I saw black smoke. Later I heard one of those B-29s had been downed by a Japanese plane.

What young Akira had seen was the downing of Bombing Mission 145 over Oita Prefecture. On that day in May, a dozen B-29 bombers were headed back to base in Guam after bombing airfields in Kyushu. Kinzou Kasuya, a nineteen-year-old Japanese fighter pilot, chased after one of the planes and rammed his small aircraft into the fuselage, destroying his plane but also bringing down the B-29. The young pilot crashed and died. As villagers from the small town of Takeda watched the air battle, twelve parachutes opened, with the Americans falling toward them. One young boy, watching from nearby Oita City, remembers, "Standing in front of a shelter, I remember that scene as though I was watching a movie." One of the Americans fell quickly to earth and died after his parachute cord was severed by a second Japanese plane. A second airman landed and immediately began emptying his pistol as the villagers attacked him and the other Americans. He saved one bullet for himself just before capture. Two of the others were pounced on by the villagers and quickly stabbed and shot to death. The other eight were beaten, stabbed and held, awaiting authorities to take them away. The wrath of these farmers represented a national sense of fury brought by the grim results of the B-29 raids throughout the country. ${ }^{7}$

The Americans were then bound and moved to the train station in Oita City. First Lieutenant Marvin Watkins, the only crew member to survive the war, recalled in testimony given in 1947, "At the time of my capture I was handcuffed and blindfolded and placed on a train and traveled on this train from 20:00 to 24:00 on May 5. I attempted to ascertain the direction of our travel but due to the blindfold I was unable to determine location or direction." ${ }^{8}$ Just after the end of the war, in October 1945, the commander wrote letters to the family members of his crew. In a letter to the wife of Dale Plambeck, one of those tortured to death in Fukuoka, he wrote:

7 ThomasEaston, “AQuietHonestyRecordsaWorldWarIIAtrocity,"BaltimoreSun,May28,1995, http:// articles.baltimoresun.com/1995-05-28/news/1995148003_1_japan-kyushu-university-fukuoka. 8 Interrogation of Marvin Watkins, For the War Crimes Office, Judge Advocate General's Department, United States of America, http://mansell.com/pow_resources/camplists/ fukuoka/fuk_01_fukuoka/fukuoka_01/Page05.htm home.comcast.net/ winjerd/Page05. htm\#Vivisections. 
Everything was normal and no fighters or antiaircraft fire was encountered until we had released our bombs and turning away from the target. There was a twin-engine fighter high ahead of us and a little to the right that made a pass on a near miss of crashing into us. A fire was started in \#4 engine and a gas tank which soon got out of control, making it necessary for us to leave the ship before an explosion occurred. The bailout signal was sounded and all left the ship in an orderly manner. The engineer and I were the last to leave and by that time the wing had burned off and the ship was out of control. We had hoped the fire might burn out. I can authentically say that your husband left the ship and parachuted down safely for I was later captured and held as prisoner in an adjoining room to Dale. There were five of us together but in separate rooms at some army camp near where we crashed. Japanese customs and policies forbid us to talk to each other, but in spite of this Dale and I had a few words together. He was alright and said all the boys in his compartment got out and they parachuted down together. After about three or four days of several interrogations, I was separated from these boys and taken by train to Tokyo and there I received quite a number of very thorough interrogations and was held there as a prisoner until liberation. During this time, I was unable to contact any of my crew and to date haven't heard a word. ${ }^{9}$

Hideo Sonoda, a student worker in the military factory where the eighteen students had been killed only a few weeks before, was at the station that day.

By pure coincidence, I was right in front of Oita station the day they brought the Americans from the countryside where they had parachuted and been captured. There wasn't any announcement that they'd be there. I just happened to see them, all very tall and with blindfolds. They were guarded by a small group of Japanese soldiers as they approached the station. It was not a happy feeling I had, but rather sad to see them like this. I heard later what happened to them in Fukuoka, human science experiments and all.

What happened to the rest of the crew in Fukuoka has been documented through official United States records and testimony from Japanese medical personnel who dealt with them. First Lieutenant Watkins was sent to 
Tokyo for questioning, where he was tortured but survived the war. The other men were sent to Kyushu University Hospital in nearby Fukuoka, which had been commandeered by the Japanese military, where they were vivisected by army doctors and medics. The experiments on these men were particularly gruesome, including removal of vital organs, amputation of limbs and injection of sea water into veins, all while alive and conscious. The kill-all order protected the authorities until after the war, when 23 of them were found guilty of war crimes. However, none were executed.

A memorial to these two events, the air collision in Oita and the vivisection experiments in Fukuoka, was erected by some of those who witnessed B-29 crash. Hanako Kobayashi was a young woman in 1945 who was first to arrive at the wreckage of the Japanese plane, which had crashed on her property. She wiped the blood away from Kinzou Kasuya's face, and watched as his body was carried away on a stretcher made from a neighbor's door. In 1976 she was persuaded by members of Kasuya's squadron to erect a small memorial in his honor. Fumio Kudo, a farmer living only a few kilometers from Hanako Kobayashi, owns the land where the B-29 crashed. On his own initiative he erected a stone memorial to those Americans who died there and in Fukuoka. For many years, on each May $5^{\text {th }}$, a ceremony has been held to jointly honor both the Japanese pilot and the American airmen. Buddhist monks chant for those who died and banners read, "Dedicated to a young Japanese soldier and the crew of the B-29 which crashed here." In this case, the people of Oita have recovered from the horror of the fire rained down on them from the B-29s and reconciled with their former enemies while remembering their war hero. In 1981 Commander Watkins wrote to the citizens of Takeda to thank them for their efforts to remember those who died:

To the People of Takeda City, Oita Community,

A memorial is an occasion of inspiration and sorry. We are inspired by the value of those who place National Safety above personal survival; saddened by the loss of bright and honorable lives. Nations have been engaged in many wars and battles. Many have died. They died to preserve their country and all it stood for, stands for, and all it will continue to stand for in the years to come. I, Marvin S. Watkins, B-29 Aircraft Commander on a flight over Kyushu, Japan, May 5, 1945, commend and pay homage to the citizens of Takeda City, Oita area for the erection and dedication of a memorial to the memory of my aircraft crew and others who offered their lives in the sky. You have without doubt in my mind spared no efforts in making it possible to erect the monument at an appropriate location. 
I offer my sincere prayer for the souls of all Americans and Japanese in whose memory the memorial is erected. Let us never forget those who sacrificed their lives for the present peace and friendship between the United States and Japan. May the people of these two great nations forever share the relationship we have shared for the past 36 years. Marvin S. Watkins, May $5,1981 .^{10}$

It took 70 years for Japan to formally and publically acknowledge the imprisonment and torture of the American airman. In April 2015, the Japan Times reported, "A new medical history museum in Fukuoka faced the area's dark wartime past on Saturday by using its grand opening to finally address the infamous live dissections of U.S. prisoners of war that took place at Kyushu University's medical school." The museum details the procedures carried out on the men and lists their names. ${ }^{11}$

\section{Meanwhile on Okinawa}

In early May the slaughter ran unchecked on Okinawa and Slim Carlton recounts the intensity of the fight, while picking up a souvenir. It would be his second, as he had already collected a spirit belt woven by family members of a dead Japanese soldier.

Where I stood the bank was about four feet high, and there, not ten feet away, was a Japanese soldier! He was almost hidden in the bamboo. His head was turned away from me. He was looking intently at my machine gun at the top of the rise. There I stood, my carbine eight feet away! What a dummy! My heart stopped. I dropped to my knees and crept toward my rifle. My head was below the bank and out of sight. Carefully I slid the safety to "off." In one motion I stood, swung the carbine over the bank, and fired three times. No need to aim at that point-blank range. His body jerked. His helmet flew off. This brought one and all to their feet, weapons ready. "What the hell is going on?" several asked. "I just shot a Jap who was sneaking up on us through the bamboo," I replied.... Frank, one of

10 Interrogation of Marvin Watkins, For the War Crimes Office, Judge Advocates General's Department, United States of American, Ibid. home.comcast.net/ winjerd/Page 5 . htm\#Vivisections.

11 "New Kyushu Museum Breaks Taboo with POW Vivisection Display," Japan Times, April 4, 2015, http://www.japantimes.co.jp/news/2015/04/o4/national/new-kyushu-museum-breaks -taboo-with-pow-vivisection-display/. 
the best souvenir hunters, climbed the bank and through the brush. He searched the soldier's pockets but found nothing worth keeping. He then retrieved the helmet from where it had flown. He crawled back into the road cut. He handed me the helmet.

"Looks like one of your rounds went right through his hat," he said. He was correct. I found a neat hole then some blood and gray matter splattered inside. "Hey, look. There's a flag folded inside," I exclaimed. I unfolded the flag, trying to avoid getting as much "muck" as possible on my hands. Unfortunately my bullet had penetrated the flag many times leaving a pattern of ragged holes. It had been a beautiful flag. It was about two by three feet in size of a heavy silky material. The red "meatball" in the middle had rays of Japanese calligraphy radiating to the outer edges. A real prize except for the holes, blood, and brain matter. I refolded it as best I could and placed it in my pocket. ${ }^{12}$ 


\section{Donate Everything}

\section{Children Join the Army}

The government demanded new sacrifices. Seiichi Kogo, then working in a factory as a student, remembers, "At one point the government ordered us to demolish our house in order to build shelters and to prevent fire from spreading. Many houses were torn down; my home was just one of them."

Another sacrifice demanded of the youth was reported in the local Oita newspaper in early May. Schoolchildren were now being recruited to military service.

From the May 7, 1945, Oita Godo Press:

In preparing to strengthen the air force, the Oita Branch of the Great Japan Flight Association will hold preliminary training, including flying drills for juvenile flight soldiers at former Beppu Golf Course in Hayamugun from May 12 through June 10. After careful consideration, on the afternoon of May 5, the section committee, including Sato-sensei, the academic head, and Abe-sensei, the physical education teacher, selected 40 students who excelled both in their studies and in their behavior to join this training. Of the 40,25 are from Beppu, 4 from Ishigaki, 5 from Kamegawa, 3 from Asahi, 2 from Kita-aoyama, and 1 from Minamiaoyoma. The students will undergo intensive, around-the-clock training, including disciplinary rules, flying, and physical exercises. The purpose of the training is to prepare them so that they can qualify as juvenile flight soldiers in the future. ${ }^{1}$

Day after day, the war increasingly crowded the pages of the local newspaper. The May 7 edition headline warned of an increasingly sinister tactic in American bombing:

\section{Enemy Carrying Out Psychological Warfare}

Recently, attacks by B-29 bombers have become more frequent. A large number of time bombs were dropped on May 7 and 8. Citizens do not need to be afraid of these time bombs because the power of time bombs

1 Oita Godo Press, May 7, 1945, p. 2. The locations listed here are all part of what is today the city of Beppu, though at that time each small district maintained its own independent legal identity. 
is relatively weak. The enemy has adopted psychological warfare to intimidate us, as the nature of time bombs is that it is impossible to predict the exact time they will explode. We should not be deceived by them and continue to fight until the final victory. ${ }^{2}$

In the village of Ono, just outside Saiki, these bombs found their way into farmers' fields and homes. Eiji Ono, not yet five years old at the time, recalls stories his mother told him, and then recounts his own experience with the time bombs:

The time bombs were intended for the naval base several kilometers from our home, but some landed close to our house. One person and one cow were killed. Near Saiki, nineteen people perished when time bombs exploded in their shelter. My mother said she'd seen pieces of bodies hanging from trees. Once while playing in the field nearby, I found an unexploded time bomb but did not know what it was. It was colorful, so I brought it home and left it just inside the front door. My father was fighting in China at the time, and I lived with my mother and grandmother. When they saw the time bomb that I brought home, they called the authorities to take it away.

At the same time, the government inserted stories in the newspapers in a feeble attempt to show that life in Oita remained somewhat normal amid the chaos. For example, the day after announcing the recruitment of boy pilots in the newspaper, agricultural innovations were highlighted.

From Oita Godo Press, May 8, 1945:

On May 6, Hayami Branch Office of the Farmers' Association called a meeting with its chief engineers belonging to the local municipality to discuss the following agenda:

- Latest achievements of effective farming movement by the whole village

- Increasing production of sweet potatoes

- Preparation for rice paddy seeding

- Adjustment of labor

- Instruction and cooperation related to the contribution of primary school students 
- Instruction on knowledge and techniques concerning food production and foraging

- Donation of vegetables

- Actions taken to retain engineers ${ }^{3}$

But such stories appeared less frequently as the months went by. In the May 10 edition of the Oita Godo Press, the people learned of Germany's surrender. They knew they were now fighting alone, and if they were to win the war, it would take every person to contribute. On the same day, the newspaper interviewed a $2^{\text {nd }}$ lieutenant named Oba, a representative of the military who tried to shore up public morale while exhorting everyone to work harder to win the war.

Germany has now surrendered. This will affect the East Asian War both directly and indirectly. I don't think the Allied air attacks and naval fleets from Europe will come to East Asia all at once, but certainly they will appear in the near future, at which time their attacks will become very intense. To win the war, we must produce more airplanes.

The successful landing in Normandy achieved by the U.S. and Britain was a result of their overwhelming air power against Germany. They mobilized thousands of bombers over Germany day after day. The same thing can happen on the East Asia war front. Our air force was inferior to that of the U.S. in the recent battles on Saipan and Iwo Jima. I should insist, again, that we have to win this war. For that purpose, we need additional airplanes more than anything else. Those who are engaged in producing airplanes should realize that one airplane for today will decide the fate of our country tomorrow. And our citizens should donate everything to produce more airplanes. ${ }^{4}$

\section{Kamikaze Nightmares}

As Japanese citizens learned of Germany's surrender, and wondered what it foretold about their own destiny, the students of Oita labored feverishly to prepare the airplanes so desperately needed, including those for kamikaze pilots. At the same time, U.S. marine E. B. Sledge sat in his foxhole with eyes and thoughts turned wearily in two different directions. He watched 
for the enemy, fearing a charge at any minute, while looking out to sea as scores of kamikaze attacked his navy.

At first light we heard Japanese planes attacking our ships and saw the fleet throwing up antiaircraft fire. There was a massive enemy air attack against our fleet at this time. We saw kamikaze fly through a thick curtain of flak and crash-dive into a cruiser. A huge white smoke ring rose thousands of feet into the air. We heard shortly that it was the cruiser USS Birmingham that had suffered considerable damage and loss of life among her crew.

On 8 May Nazi Germany surrendered unconditionally. We were told this momentous news, but considering our own peril and misery, no one cared much. "So what" was typical of the remarks I heard around me. We were resigned only to the fact that the Japanese would fight to total extinction on Okinawa, as they had elsewhere, and that Japan would have to be invaded with the same gruesome prospects. Nazi Germany might as well have been on the moon.

As midday approached on 9 May everyone was tense about the coming attack. Ammunition had been issued, men had squared away their gear and had done their last-minute duties: adjusting cartridge belts, pack straps, leggings, and leather rifle slings - all those forlorn little gestures of no value that released tension in the face of impending terror....

The order came to secure the guns and to stand by....

Our position got a heavy dose of Japanese gomm counterbattery fire. We had a difficult time keeping up our firing with those big 9omm shells crashing around us. Shell fragments whined through the air, and the big shells slung mud around. But we had to keep up our fire. The riflemen were catching hell from the flank and had to be supported. Our artillery began firing again at the enemy positions to our left to aid the harassed riflemen. ${ }^{5}$

We always knew when we were inflicting losses on the Japanese with our $60 \mathrm{~mm}$ mortars by the amount of counterbattery mortar and artillery fire they threw back at us. If we weren't doing them any damage, they usually ignored us unless they thought they could inflict a lot of casualties. If the Japanese counterbattery fire was a real indicator of our effectiveness in causing them casualties, we were satisfyingly effective during the Okinawa campaign. ${ }^{6}$ 
On May 11, the American ship Hadley was crippled off Okinawa. The experience is chronicled by those who were on board at the time.

"This was the granddaddy of them all," recalls Jay Holmes, who watched the onslaught from the bridge. "We didn't have time to count, but the records show the kamikazes came at us ten at a time. As good as our gunners were, there was no way we were going to stop them all."

The mass attack began at 9:20 a.m., when an Oka rocket bomb narrowly missed the ship. Seconds later, another suicider aimed for the bridge but overshot it and hurdled between the Hadley's twin stacks. A wing sheared off, ripping out a section of the destroyer's rigging and its main radio antenna but causing little other damage.

From his post underneath the five-inch batteries, Leo Helling heard or felt a hard bump and glanced up toward the bright patch of daylight a deck above him in time to see his gun captain duck sharply and almost lose his footing.

"God almighty, that was close!" the captain howled.

It wasn't as close as the next one, however. The second hit came squarely on top of the port-side quad-4o that had been Helling's battle station until two days ago, fatally wounding every member of its crew. As the plane exploded, the pilot released a bomb into the same area, wiping out several other 40- and 20-millimeter mounts. The plane's blazing wreckage then careened into the deckhouse atop the main afterdeck, engulfing in flames the lockers and living quarters for most of the Hadley's junior officers.

Seaman First Class Franklin Gebhart, gun captain on one of the starboard 4os, thought for sure that the first suicide plane "had my name on it," but its glancing blow merely bounced him against some torpedo tubes and knocked the wind out of him.

"I ordered my men to abandon ship, and they all jumped but two, who kept firing," Gebhart recalled. "Then another kamikaze hit the gun and killed them both, and I jumped overboard, too. I was bobbing around out there when I saw one of our Corsairs, whose ammo was totally gone, come down on top of a Jap plane and ride him down into the water."

A moment later, the third successful suicide plane applied the kiss of death to the Hadley when it crashed the reeling destroyer amidships at the water line on the starboard side. As the plane hit, the pilot released a 5oo-pound bomb that exploded underneath the ship.? 
Throughout Kyushu, the kamikaze pilots prepared for their missions against the American ships streaming toward Okinawa. Captain Morimasa Yunokawa, the commander whose planes were shot up in Usa on March 18, was now put in charge of training these pilots.

Until June 22, we were sending special attack forces [kamikaze] to attack Okinawa. I oversaw all the pilots' training and watched them go off to their attack missions. We'd send them out as quickly as the planes were ready. Before they left, I'd offer the man words of encouragement, but I didn't really have an emotional response. I expected I would be joining them soon enough. However, my commanding officer wouldn't let me go, because, if I went, there'd be no one to train the pilots. I argued that I should lead my men into battle, because that was the role of a leader. But my suggestion was dismissed, and I was harshly reprimanded even for merely suggesting that I should lead an attack. After June 22, we were not only trained as kamikaze, but also flew mock attacks on ships, as a way to train those about to sail out to sea. By the end of June, we were in Oita, where I continued training new pilots, primarily focused on navigation.

\section{The Stench of Death}

From Okinawa, the Japanese view in early May appears through the memoirs of military strategist Colonel Hiromichi Yahara. Despite the efforts of the kamikaze, by this time Yahara had changed his mind about the effectiveness of this strategy and voiced an opinion rarely heard during the heat of battle:

When our May 4 counteroffensive was terminated, all troops returned to their original positions. General Ushijima, his staff, and the troops were thoroughly discouraged, yet overall there was a strange sense of relief. Then one day a liaison officer brought me an order from Generals Ushijima and Cho saying that staff officer Major Jin, an aviator, was going to Tokyo. Puzzled by this surprising decision, I asked what it meant, and was told, "We are sending him to Imperial Headquarters to request approval for our air forces to attack the enemy fleet in strength, force their withdrawal, and thus end the Okinawa operations."

At first glance this might have seemed like a brilliant move to spare us military losses, yet every effort was already being made to destroy enemy shipping from the air. The fliers were already being made to destroy 
enemy shipping from the air.... Our Tokkotai special suicide [kamikaze] units had been striking almost daily, but enemy air strength remained far superior to ours.

As a matter of fact, air power was never a prime factor in the battle for Okinawa. The enemy had established a firm position ashore by landing six army and marine divisions. We knew that our forces were attacking them bravely, but we needed much more than bravery. Furthermore, it was ridiculous to think that the enemy would withdraw from this operation.

Japan was frantically preparing for a final decisive battle on the home islands, leaving Okinawa to face a totally hopeless situation. From the beginning I had insisted that our proper strategy was to hold the enemy as long as possible, drain off his troops and supplies, and thus contribute our utmost to the final decisive battle for Japan proper.

Since it was foolish even to dream of victory here in Okinawa, I disagreed with the idea of sending Major Jin to Tokyo. From the strategic point of view I was against it. As a tactical matter, I certainly agreed that our suicide planes should destroy as much enemy shipping as possible, but this was no more than a hope. ${ }^{8}$

From Okinawa on May 21, the American view of E. B. Sledge shows the growing frustration of fighting an enemy already defeated but unbowed.

The weather turned cloudy on 21 May, and the rains began. It was the beginning of a ten-day period of torrential rains. The weather was chilly, and mud, mud, mud was everywhere. We slipped and slid along the trails with every step we took... I remember the move vividly, because we entered the worst area I ever saw on a battlefield. And we stayed there more than a week. I shudder at the memory of it.... The mud got worse the further we went. As we approached our destination, the Japanese dead, scattered about in most areas since 1 May, became more numerous.... We slogged along through a muddy draw around the base of a knoll. On our left we saw six Marine corpses.... As we filed past the dead Marines, each of my buddies turned his head and gazed at the horrible spectacle with an expression that revealed how much the scene inwardly sickened us all.

I had heard and read that combat troops in many wars became hardened and insensitive to the sight of their own dead. I didn't find that to be the 
case at all with my comrades. The sight of dead Japanese didn't bother us in the least, but the sight of Marine dead brought forth regret, never indifference.... The stench of death was overpowering. The only way I could bear the monstrous horror of it all was to look upward away from the early reality surrounding us, watch the leaden gray clouds go scudding over, and repeat over and over to myself that the situation was unreal - just a nightmare.... We were in the depths of the abyss, the ultimate horror of war. ${ }^{9}$

In Okinawa, the end was in sight, but Japanese commanders would never surrender.

On Sunday, June 17, a message from General Simon Buckner, the enemy commander, to General Ushijima came to our headquarters cave:

The forces under your command have fought bravely and well. Your infantry tactics have merited the respect of your opponents in the battle for Okinawa.

Like myself, you are an infantry general, long schooled and experienced in infantry warfare. You must surely realize the pitiful plight of your defense forces. You know that no reinforcements can reach you. I believe, therefore, that you understand as clearly as I, that the destruction of all Japanese resistance on the island is merely a matter of days. It will entail the necessity of my destroying the vast majority of your remaining troops. ${ }^{10}$

General Buckner's proposal for us to surrender was, of course, an affront to Japanese tradition.... Lying on my bed in the dark room, I thought about the history of military surrenders. In modern warfare in the West, defeated commanders usually surrendered gracefully to the victors. This was generally true of white-race societies - from Napoleonic times, the Franco-Prussian War, the American Revolution and Civil War, down to World Wars I and II. Top commanders would generally be held responsible for defeats. And where commanders were killed, units below them were generally allowed to surrender on their own. To my limited recollection, there existed no cases of Western armies fighting to the death. When an 
army's value as a fighting force was obviously spent, they would take the course of surrendering.

InJapan, on the other hand, it was not uncommon for a losing commander and his subordinates to commit suicide.... Indeed, it is a high ideal to fight to the end to maintain national morale. But were our leaders worth the sacrifice of an entire people? With the end of the war in sight, they shout at us: "Millions of people must die for our nation." Why? Are they really aware of the entire war situation? It was foolish to force everyone to die, simply because Japan had never before lost a war. ${ }^{11}$

The culture, indeed the glorification, of honorable suicide permeated the Japanese military and the citizenry. As the battle for Okinawa moved toward total defeat of the Japanese, suicides among their soldiers grew in intensity. From the American soldiers' view, this was observed with fascination, for it was something so outside their own code of honor and army experience.

On one occasion we stumbled upon a severely wounded soldier. Gangrene had consumed a large portion of one leg and he had suffered a wound to his groin also. We would have tried to help him, but when he saw that we were American soldiers, he pulled a grenade from inside of his shirt, stuck it on the ground,... placed it behind his head, and laid his head back. The explosion threw him forward. When he fell back he landed face down. The inside of his skull where his face had been was clean as a whistle. This tenacity made it tough for us. For the first three months of the battle for Okinawa I had not witnessed one man surrender. ${ }^{12}$

From the Japanese side, the expectation that one would not be taken alive in battle permeated the ranks. Everyone on the Japanese side knew this, but to admit defeat was beyond their imagination. On June 21, knowing that the Okinawan campaign was lost and that the two commanding generals would soon commit harakiri, a message of congratulations came from General Korechika Anami, Imperial Army chief of staff, and General Yoshijiro Umezu, minister of war. Both of these men hailed from Oita Prefecture,

11 Yahara, pp. 136-137. The date of this surrender message is incorrect in this memoir, as the actual message arrived a week earlier, on June 10. General Buckner was killed by artillery fire one week later, on June 18, just three days before the island was secured by American forces. 12 Carlton, p. 126. 
having risen to the top leadership overseeing the last months of Imperial Japan's military ventures. The message read:

For three months $32^{\text {nd }}$ Army has fought bravely under General Ushijima, a commander with great nobility of character. They killed the enemy commander, General Simon Buckner, and delivered deadly blows against his eight divisions of troops. Your troops struggled hard, preparing superbly for decisive battle. As the enemy strength increased, your troops - officers and men - responded with vows to destroy that strength.

Colonel Yahara observed the ritual suicide of his two commanding generals on the final days of the battle.

At midnight on June 23 we abandoned any effort to recover the hilltop. Generals Ushijima and Cho scheduled their hara-kiri for the morning. Both were fast asleep. At 0300 General Ushijima summoned me to his room. Dressed in full uniform, he was sitting cross-legged. General Cho was drinking his favorite King of Kings whiskey, and he was very intoxicated. They were surrounded by familiar faces. I solemnly saluted them but said nothing. Cho offered me whisky and a piece of pineapple that extended on the tip of his sword. This startled me but I ate it. Cho said, "General, you took a good rest. I waited patiently for you to waken, for time is running out."

Ushijima: "I could not sleep well because you snored so loudly. It was like thunder."

Cho: "Who will go first, you or me? Shall I die first and lead you to another world?"

Usijima: "I will take the lead."

Cho: "Excellency, you will go to paradise. I to hell. I cannot accompany you to that other world.... I will drink King of Kings while awaiting death." He laughed heartily.

The two generals exchanged poems back and forth. I could not hear them clearly, but I recall their mention that Japan could not exist without Okinawa. Time was running out. Everyone in the cave formed a line to pay their last respects. Major Ono, a man of innocent face and indomitable spirit, returned and reported that the final message had gone to Imperial General Headquarters. It read:

"Your loyal army has successfully completed preparations for homeland defense." 
General Ushijima quietly stood up. General Cho removed his field uniform.... Led by candlelight the solemn procession headed for the exit, with heavy hearts and limbs.... General Ushijima sat silently in the death seat, ten paces from the cave exit, facing the sea wall. General Cho sat beside him. I was a few steps away. The hara-kiri assistant, Captain Sakaguchi, stood behind them.... Soldiers stood at the exit, awaiting the moment. General Cho looked over his shoulder at me with a beautifully divine expression and said solemnly, "Yahara! For future generations, you will bear witness as to how I died." The master swordsman, Sakaguchi, grasped his great sword with both hands, raised it high above the general's head, then held back in his downward swing, and said, "It is too dark to see your neck. Please wait a few moments."

With the dawn, the enemy warships at sea would begin to fire their naval guns. Soldiers at the cave entrance were getting nervous. Granted their leave, they fled and ran down the cliff.... The generals were ready. Each in turn thrust a traditional hara-kiri dagger into his bared abdomen. As they did so, Sakaguchi skillfully and swiftly swung his razor-edged sword and beheaded them. Ushijima first, then Cho. Like a collapsed dam, the remaining soldiers broke ranks and ran down the cliff. I sat down outside the cave with Captain Sakaguchi, who declared with solemn amazement, "I did it!" His ashen face bore a look of satisfaction.

It marked a glorious end to our three months of hard battle, our proud $32^{\text {nd }}$ Army, and the lives of our generals. It was 0430, June 23, $1945^{13}$ 


\section{Eliminate the City}

\section{Targeting Civilians}

As the government prepared for an invasion of the main islands of Kyushu and Honshu, citizens of Oita City had every reason to fear a terrible death, for American tactics shifted and the ability of the Japanese Navy and Army to hold off the air attacks was nearly exhausted by the end of the battle for Okinawa. The Americans were now explicitly targeting civilians. The diary entry of B-29 airman Staff Sergeant Jim Swalwell makes clear the intention of his crew. "Monday, July 16, 1945. Our target tonight is the city of Oita, on the coast of Kyushu. We have bombed airfields there a couple of times and tonight we are going to try to eliminate the city. This is the first fire raid on any city in Kyushu. We're carrying 180 of the little 100 pound fire bombs. There isn't supposed to be very much opposition." The people were, quite literally, sitting targets.

What transpired on the ground that day in Oita City shows just how successful the mission was, and how the American plan to "eliminate the city" was viewed more personally by Oita residents as a plan to eliminate the people by burning them to death.

Kenji Hanamoto recounts his experience in his memoir "As a Young Boy":

That night, an incendiary bomb fell through our ceiling, landing in the entrance and starting a fire. It was a monster of a device, approximately one meter long. The walls, tatami, and ceilings were on fire. Even after the fire was put out, the bomb would continue to burn and shake. It was a small yellow flame. I kept pouring water on the fire, but it simply would not go out. I started to go crazy and kept saying to myself, "What the hell is this thing!?"

Eventually, I dragged the device, as it sputtered fire, to a water tank and dumped it in the water. In an instant, the water started to boil as the device was still bright yellow. It must have taken a long time for me to do this and to get out of my house. By now, the entire city was on fire, and there was not a trace of life. I thought I had been left behind. The thought scared me to death. Without thinking, I ran toward Bishamon River. On 
the way, there was this little boy, must have been four or five years old, just standing in the middle of the street, crying.

There was no time to ask what happened and where his parents were, I grabbed him by the arm and dragged him along with me. On both sides of the streets, houses were engulfed in flames and caved in one by one. Two-story homes crumbled like straw houses. The heat was so intense, that it burned my eyes. I couldn't breathe; my head started spinning; and I doubled over in pain.

To this day, no matter how hard I try, I can't recall when I let go of that little boy. I knew I had brought him, but where was he? Was I hallucinating? But I wasn't dreaming. No, it wasn't an illusion. I turned back and searched for that boy, but I never saw him again.

I ran another 30 or 40 meters and saw a hospital. Someone had left a bucket of water. I took a sip and dumped it over my head. I finally made it to the Bishamon River and breathed easier.

It's been 28 years since that day, and I am now a father of two. I have told my children of that horrible night and the child I found and lost. I still pray for his safety, and if he died, that he rest in peace. I pray for his family. ${ }^{2}$

Takaura Teruaki, a military school student from Kumamoto, was visiting Oita at the time of the July 16 raid. He recalls:

From far away, the enemy planes shook the sky. B-29s. Tonight, I thought, Oita might get destroyed. So I knew I had to get to our shelter quickly. Well, it was really just a shallow hole in the ground. You couldn't really say the shelter protected much. So we went into the pumpkin field where we covered ourselves with a camouflage net, hoping we looked like a part of the pumpkin field. The sounds emanating from the sky indicated that many planes were on their way. Then the bombings started. There was a mysterious shuffling sound that I had never heard before.

I found out later that a long ribbon was affixed to each six pound incendiary bomb, which guided it to its target. The ribbon whistled in the wind as it traveled down to the ground. The loud explosions of bombs hurt your chest, but the chorus of many ribbons shuffling in the air was different. It sent fear through your entire being. I was fourteen at the time, a third-year middle school student training for the military. But that didn't make it any less scary. 
All of a sudden, I realized "Shit!! I forgot my hat at home!!!” I was in trouble! Another student had been kicked out of the army because his military uniform was burned in a fire. It was not a time to be afraid, and I had to go home and retrieve my hat. My mom grabbed me tightly to make me stay in the shelter, but I struggled out of her grip and ran home. I found my hat where I left it, but just as I was about to leave, our house began to shake. Stepping out, I saw that the entire sky was stained red with fire. The bombings intensified. I strapped my hat to my head, took a bucket, and tried to put out the fires, but soon abandoned my attempt. I went out toward Oote-dori. Just ahead, Tenjincho-dori was on fire, flames raging on both sides of streets. I saw the silhouettes of people trying to escape. It was like a crematory. ${ }^{3}$

\section{Oita's Heroic Nurse}

Fire bombs enveloped Oita, trapping people in their homes and office buildings. The bombing lasted an hour and a half, and then the planes went south toward Saiki. One young woman's heroic actions during this bombing became legendary, with her exploits and picture appearing in the local newspaper. Her name is Nobuko Eto, the nursing student introduced earlier who was assigned to warn everyone in the hospital when bombing was imminent. She recalls that day:

I was working on the first floor office of the National Hospital in Oita City center. By that time, many of the doctors were taken away to serve the military, leaving only nurses, nursing students, and a few doctors who didn't qualify to enlist due to health reasons. When the air raid warning came, I took the megaphone and ran around the hospital to warn everyone. I felt that the B-29s were headed directly toward me. They flew very low and made a sound that reminded me of a train. An incendiary bomb came through the roof of the hospital. The fire jumped toward the main building; some of us ran back and forth carrying buckets of water from the well to pour over the fire; others lined up as a human chain passing buckets of water between the well and the building. We drenched ourselves with water to fight off the heat. All I could think of was, "What if this fire spreads to the ward where patients sleep!" I started tearing out 
parts of the roof and cut the support beams of the hallway. Somehow, in the end, we were able to prevent the fire from spreading further.

I went outside and saw only red and blue flames in every direction. The whole city was a sea of fire. Inside the hospital, both the old and new nursing houses had gone up in flames. Beyond the hospital, we could see absolutely nothing, except black smoke where buildings once stood. A few days after the bombing, the burnt skin on my face began to peel away. By this time, the hospital was crowded with injured people who had no home to return to. People had no food, and children had lost their parents. I did what I could, making miso soup from water I got from the ocean.

The local newspaper recounted Nobuko's heroics with the headlines, "The Nurse Who Would Have Died to Protect the Hospital" and ended the story with, "Protecting the hospital with her life, she and the others thought, 'We won!' 'We won together,' they cried, looking around at what was left of the hospital. The evacuated patients heard of their efforts and thanked them endlessly when they were allowed to come back to the hospital."

The massive bombing of July 16 left the people of Oita shattered and clinging to the barest essentials, as recounted by an Oita historian:

According to the prefecture reports, 2,488 houses were burned to the ground. 49 people died, 122 were severely injured, and 10,730 people lost their homes in this one single attack. The city center was burned to the ground in this unholy shower. The sun eventually rose after the long and painful night. Some buildings were still intact. Some buildings still stood on the surrounding hills, but everywhere you looked, there was devastation.

What's surprising is the small number of people killed and injured. This was because many people had already abandoned their homes to live in the countryside and because many people evacuated to higher ground. The mayor's office issued rations of two meals of dry noodles (dried and hardened udon and somen) and a rice ball to each person. The injured and sick were taken to local schools for treatment and an emergency control room was established at the Ken Kyoiku Center.

By noon the next day water was running again and by nightfall electricity came back on. People who lost their homes built shelters where their houses once stood. They lined up for their rations still reliving the hellish nightmare, but grateful and happy they survived. ${ }^{4}$ 


\section{Too Many Bombs, Too few Targets}

On July 25 the Americans raided Oita City yet again with 47 B-29s and several Grumman fighters. But bombing did not stop at Oita City. On that day, only three weeks before the end of the war, Hoeshima, a small island off the Bungo coastline, was attacked as the planes left their primary target. Orders allowed for discretionary targeting, and one pilot flew toward the island to unload his remaining bombs. He found an elementary school.

Hoeshima Elementary School housed 960 students. Around 9 o'clock in the morning, the students and teachers heard the sound of planes approaching. Soon, they could see the silver B-29s heading north. Thinking that an elementary school of all places would be safe, classes continued as usual.

Just when all thought the planes were gone, someone shouted, "It's a raid!!" All at once, an explosion ripped the ground under the children. A Grumman dropped four bombs and one hit directly on the school grounds. This is a perfect example of how the American's conducted their genocide. When the raid was over, 124 students had died along with two teachers and one supervisor, and 69 children and six teachers were injured. ${ }^{5}$

After the attack in Oita City on July 16, bombers struck again on July 17 and 29, and August 9, 10, and 11. Damage from these attacks included multiple deaths, destroyed homes, and a number of shrines turned to rubble. August 11, just four days before the end of the war, proved to be the very last attack on Oita.

Through the middle of August, the civilians of Oita had suffered much. Data compiled from between the first bombings in Oita Prefecture on March 18 through the last bombing on August 11 shows the following numbers:

Planes Attacking Oita Prefecture: 3,000

Number of Attacks: 85

Number of Traditional Bombs: 1,650

Number of Incendiary Bombs: 9,500

Number Dead: 485

Number Injured: 718

Houses Destroyed: 6,504

5 Ibid., pp. 83-84.

6 Hoashi, p. 85 . 
As the war reached its last days, American pilots roamed the skies, but began to cut back on the severity of their bombing and strafing. While children were killed and maimed during the July 25 raid, other children found themselves playthings for the pilots. Some can never forget their experiences with these American pilots looking down on them from only a few hundred feet above the ground. Eiji Ono and Sadayoshi Yutani, neither one yet old enough to enter elementary school at the time, remember clearly their childhood encounters with the Grummans. Eiji Ono of Saiki recalls:

In the days just before the war ended, the Grummans would come in unopposed, so the pilots could shoot up whatever they wanted. Before people had been killed, but now, near my home they only shot up the roads, forests, and farmlands. But we never felt that they were targeting us, even when we were caught out in the open. They weren't trying to kill us, but just having fun. They also started dropping leaflets, written in Japanese, telling us that Japan could not win the war. I remember they read, "Surrender, surrender, and then you can be free." "Peace will come soon." We were told not to pick up the leaflets, but we did anyway, and I took them to show my mother and grandmother. My grandmother kept them, and then in school we told our teacher about the leaflets. The security police came to investigate and questioned my grandmother. She could have been in trouble, but she was known in the community for supporting the army and they just gave her a warning.

Toward the end of the war, Sadayoshi Yutani moved with his mother to her home village located in the middle of a mountain range. It was still not far enough away to escape American fighter planes.

My mother thought we'd be safe in the middle of the mountain, so I'd go out and play by myself. Sometimes I went out to the rice paddy, where there were lots of fish. I would catch some and take them home to my mother. One day, while I was fishing, an American fighter plane came and fired his machine gun at the forest, spraying the trees around me. I was terrified and started to run as fast as my little legs could carry me. Luckily, there was a shelter, and I collapsed into it. There was a man in the shelter hiding from the shooting, too. After the plane flew away, for the life of me I couldn't get up and walk. The man carried me on his back and took me home. Only much later when I thought back on that day, did I realize that, by this time of the war, the American pilots were just playing with us. 


\section{Oita's Advisors to the Emperor}

\section{Never Surrender}

While the citizens of Oita dealt with the double fear of continued air raids and the imminent invasion of American troops, six men met in Tokyo to decide Japan's next steps, now that there was general agreement Japan could not win the war. These six men comprised the elite Supreme War Leadership Council, and they answered only to the emperor, who charged them to advise him on how to end the war. Amazingly, three of those six men hailed from Oita Prefecture. The debate was fierce, and the six men split down the middle. Three voted to accept the Potsdam Declaration conditions of surrender they had received in late July, before the atomic bombings of Hiroshima and Nagasaki. There was no way to continue at this point, they argued, if the country was to be saved at all.

The other three argued for continuing the war and for a life-or-death defense of the homeland. Their goal was to arm the entire populace and wear down the Americans as they invaded Japan proper while killing as many as possible. That way, they argued, Japan would achieve more favorable terms that would, at minimum, maintain the role of the monarchy and protect the life of the emperor. These three military leaders were not about to acquiesce to any forced unconditional surrender. It was the three Oita men who argued this position. They were General Yoshijiro Umezu, General Korechika Anami, and Admiral Soemu Toyada. Just outside this circle, but still involved in the discussion, was another man from Oita, former foreign affairs minister Mamoru Shigemitsu. A careful bureaucrat, the foreign minister favored a quick end to the war but had no vote in the matter. Thus, in the last days of the war, this small, rural prefecture provided half of Japan's supreme military leadership and the head of the Foreign Ministry. It is, by any account, an extraordinary contribution from one prefecture. The personal history of these four men offers a glimpse into the lives of wartime Japanese leadership as nurtured by Oita Prefecture.

\section{The Advisors}

General Yoshijiro Umezu hailed from Nakatsu, on the northern border of Oita Prefecture. Born in 1882, he graduated at the top of his class from the Imperial Japanese Army Academy in 1903 and served in the infantry. Umezu 
traveled to Germany and Denmark for further study, and was appointed military attaché to Switzerland from 1919 to 1921 . He was sent to China in the mid-1930s to take command of the China Garrison Army and later to serve as commander in chief of the Kwantung Army in Manchuria. In 1944 he was appointed chief of the Imperial Japanese Army General Staff and a member of the Supreme War Council, where he argued for the continuation of the war up until the surrender. After the war, Umezu was found guilty as a war criminal and died in prison in $1949 .{ }^{1}$

General Korechika Anami was born in the small town of Takeda City in southern Oita Prefecture in 1887 . This was the same city where the B-29 was downed and the survivors sent to Fukuoka for medical experiments. When the war finally ended, Anami was serving as minister of war. Like his fellow Oita natives Minami and Umezu, he graduated from the Imperial Japanese Army Academy and joined the infantry. He served as military attaché in France in 1925 and aide-de-camp to Emperor Hirohito from 1929 to 1930. Like Umezu, his military career focused for several years on the war in China. There he led Japanese divisions for much of the war, then transferred to Papua New Guinea in late 1943. Like Umezu, he joined the Supreme War Council in 1945. He committed ritual suicide on August 15, just after the emperor announced Japan's surrender. ${ }^{2}$

Admiral Soemu Toyoda was born in 1885 in the town of Kitsuki. In 1905 he graduated from the Imperial Japanese Naval Academy. He traveled to Europe for the navy, serving as naval attaché to the United Kingdom from 1919 to 1921. Toyoda directed naval operations during several years of the war with China and eventually played a major role in the attack on Pearl Harbor. He ended the war as supreme commander of the Imperial Navy and, as such, was a member of the Supreme War Council. He was imprisoned for a while after the war, but never charged as a war criminal.

Mamoru Shigemitsu, born in 1887, also hailed from Kitsuki. A graduate of the Law School of Tokyo University in 1907, he entered the diplomatic corps and served in several countries, including as ambassador to the United Kingdom and the Soviet Union. He also spent time in Germany, the United States, and China. In 1932, while attending a birthday celebration for Emperor Hirohito in Shanghai, a Korean nationalist detonated a bomb at the reviewing stand, killing and wounding several Japanese officers and officials.

1 Bix, pp. 514-515; “Umezu, Yoshijiro," Generals.dk, www.generals.dk/general/Umezu/ Yoshijiro/Japan.html.

2 Kent G. Budge, “Anami Korechika (1887-1945)," Pacific War Online Encyclopedia (2007-2009, 2014-2015), http://pwencycl.kgbudge.com/A/n/Anami_Korechika.htm; Bix, pp. 492, 500. 
Shigemitsu had his right leg torn off, walking with an artificial leg for the rest of his life with a sharp limp and using a cane. Though an opponent of extreme militarism who was fearful of the consequences of expanding the war to the United States and Europe, he nonetheless supported the war effort and the central authority of the emperor until the end as foreign minister and advisor to the emperor. He went to prison as a war criminal, and upon release in 1950 began to rebuild his career in government. $\mathrm{He}$ eventually regained his position as Japanese foreign minister. ${ }^{3}$

That such a disproportionate number of elite military and bureaucratic leaders were born in the same generation in the same rural prefecture of Oita is both surprising and intriguing. It also calls into question the reasons for such concentration of power in one prefecture far from Tokyo. It is well known that the farming and fishing villages of Kyushu have traditionally provided a large number of soldiers and sailors to the Japanese military. Oita was no exception. But why so many from so small a place? We would ask the same questions if the United States secretary of state, chairman of the joint chiefs of staff, head of naval operations, and commanding general of the United States Army concurrently all came from the same small coastal region of South Carolina or Georgia. Former prime minister Murayama, who served in the Imperial Army during the war, dismisses any special Oita character or inclination. "It is just a coincidence," he argues. Perhaps. But it does raise questions that still intrigue us. One possible explanation grounded in the economic realities of the prefecture is provided by a local observer of the military history of Oita. "If one grew up in Oita at that time there were only three routes to a professional career. One was to become a teacher, another to become a bureaucrat, and last to enter the military. Joining the military was the most prestigious."4 It must also be assumed that personal and family connections, loyalty to the local community, and mentoring based on a common hometown or prefecture could not have hurt. In the end, while it is most likely due to a combination of the three, it remains a striking phenomenon. 


\section{The Lightning Bolt}

\section{Digging In}

The Battle for Okinawa was obviously lost, despite the brave face put on by the commanders in the field and in Tokyo. Generals simply do not commit suicide, even in Japan, when they have won a major battle, and the suicides were mounting. The country now waited for the invasion of the southern island of Kyushu. Resistance in the air proved negligible at best, as few airplanes were in flying condition despite desperate attempts to patch them up and return them to the air, if only with young untrained pilots. Fortifications appeared along the coast, including newly dug trenches and shelters, and the construction of single-plane protective concrete bunkers dotted the few remaining operational air bases.

In Tokyo, Hiji's Isematsu Matsumoto continued his service as a member of the Imperial Guard. Bombs dropped around the palace with increasing frequency, and the emperor hid in his underground quarters while Isematsu and others did what they could to shore up the defense of the palace grounds. But the bombs were getting closer.

At one post, a bomb fell and killed five of our guards. You couldn't tell who they were, their bodies were blown to bits, and the ones left were bleeding internally. Because I was in charge of the area, I had to go to the shrine and pray for the dead men. The emperor hid in his shelter during the raids, and, when we had funerals for those men, he never came, only sent flowers to bless them. I remember thinking how lucky these dead men were for receiving the blessing of the emperor. The bombs kept falling and our commanders trained us to prepare for war to be fought on our land. I remember feeling very sad about what this meant, but I had to protect my country. So I got ready to face the enemy.

We were told that the enemy would probably land on our shores soon. And the speculation was that American tanks would come first, we began learning how to stop the tanks. My commanding officer was a young man, and he showed us these little bombs that looked like rice cakes. We were to dig holes in the ground, hide, and wait for the tanks to come close to the palace. When the tank was near enough, we were supposed to run to them, stick the bombs on the tank and blow ourselves up with it. It would be one man and one tank destroyed together. We were really hoping the Americans would be prevented from coming up ashore because none of 
us wanted to blow ourselves up, like the kamikaze, but I guess we were going to do the same. We expected to become human "meat bombs." We waited, not knowing when we would have to blow ourselves up with American tanks. We talked about who'd die first.

On August 2, Admiral Matome Ugaki, recently charged by Tokyo to prepare Kyushu for the coming invasion, moved his headquarters from Kagoshima on the southern tip of Kyushu to the naval base in Oita City. For Ugaki this was a return to Oita Prefecture, as he had begun the war with Admiral Yamamoto in Saiki while he supervised dive-bomber training exercises to prepare the Pearl Harbor attack. He had begun the war in Oita and now he would finish it there. On August 3, Ugaki's command flag was raised at a flea-and-mosquito-infested underground bunker belonging to a local farmer. He spent the next few days inspecting military installations around Oita City and Saiki, all the time preparing for the final battle. American planes strafed the city, with some bullets hitting Ugaki's headquarters residence. He heard of the bombs over Hiroshima and Nagasaki, the unexpected entry of the Soviet Union into the war against Japan, and then a rumor of surrender. But like his Oita comrades advising the emperor in Tokyo, Ugaki remained unbending in his determination to keep fighting. From his war diary just after the atomic blasts on Hiroshima and Nagasaki:

While we were completely absorbed in preparing for the last stand after being pressed to the homeland, the atomic bomb attacks and the Soviets joining the war, thus deteriorating our position, shocked us. But we can take countermeasures against them. We still have enough fighting strength remaining. It might be the view of some clever fellows to surrender with some strength left, instead of being completely destroyed, if and when we can't avoid defeat anyway. But those fellows advocating that idea are nothing but selfish weaklings who don't think seriously about the future of the nation and only seek immediate benefits.... Moreover, it's clear, too, that the whole nation wouldn't be pressed to taste the bitterness of war, and some cunning fellows would take advantage of a defeat so that the traditional Japanese spirit would be basically destroyed and even the noble spirit of revenge be lost, making the prospect of the empire extremely dark. In the end, the future of this empire will be completely ruined. Even though it becomes impossible for us to continue organized resistance after expanding our strength, we must continue guerrilla warfare under the emperor and never give up the war. When this 
resolution is brought home, we can't be defeated. Instead, we can make the enemy finally give up the war after making it taste the bitterness of a prolonged conflict. ${ }^{1}$

While Admiral Ugaki readied his remaining military forces for the invasion, and Isematsu Matsumoto trained in the art of suicide attacks on tanks rolling into Tokyo, combat training for school boys and girls continued unabated, with girls trained especially in the defensive use of long bamboo poles. As bamboo is found throughout the prefecture of Oita, this made a little sense, but not much. People had been told they should sacrifice themselves for the emperor and their country, and stories abounded of young people ready to die when the enemy stormed ashore. This sentiment is summed up clearly by Yonosuke Yanase, at the time a thirteen-year-old boy in Beppu whom Admiral Ugaki would have been proud of.

I was ready to die for Japan. I wanted to join the kamikaze, but I was too young. You had to be fourteen to join the military and if the war had continued I would have definitely gone. I wanted to join the kamikaze because I didn't want Japan to lose. Japan was God's country. As a kamikaze, I could help God's wind blow and it would change the direction of the war. In addition, it would be an honor to die for my family and my country. Families with men in the military received an honorary plaque to display in their homes. But mine was one of the few families that didn't have that so I wanted to make a name for us. At the end of the day, men were supposed to be warriors, not doctors or pharmacists. To be in the military was the highest honor, so much so that if you were not, you weren't really a man. We idolized the kamikaze and had the war gone on for another year, I would've died proudly.

\section{Nursing the Wounded}

Whether through national pride or a controlled and twisted press, the people kept vigilant. One example was 20-year-old Yukie Matsumoto of Hiji, who on April 20, 1945, entered the war as a nurse. She and 20 other young women from throughout Oita were sent to Kagoshima, the most active kamikaze center in Japan and home to a major army air base. 
I had a lot of fun going to Kagoshima. All of us felt proud and excited about the adventure. We wore the sharp and fashionable nurse uniform designed by the empress, and everyone admired us. We took the train to Kagoshima. From there, we rode a horse-drawn carriage to the military hospital. However, even before we reached the hospital we found out that it had been moved to a makeshift facility in the mountains. American planes bombed the area almost every day. We treated those injured from the bombing, mostly soldiers, but also some civilians. The conditions were horrific; those who were severely injured didn't survive. There would be dozens of those wounded lining up in front of the operating room waiting for surgery. Those with leg wounds that didn't need amputation were just turned away immediately. The wounded were treated according to their severity. It was terrible. We listened to many stories from the soldiers, and then had to make the awful decision of who'd get treatment and who would be just left to die. We felt this tremendous sadness when we had to make these life-or-death decisions. But my spirit never broke. I had to be a nurse, and so I was. I was there only a few months, then the war ended. But the experience was life changing. There's not a nurse who lived through this trauma who wasn't changed.

\section{No Taste for Invasion}

On the American side, there was no enthusiasm for an invasion. Soldiers knew from the brutality of many battles, especially Okinawa, where defense of the homeland took on a particularly gruesome character, that the Japanese people would fight to the death. There was little taste for that, from the common soldier to the president of the United States. But the Japanese had not surrendered despite their troops being defeated, even decimated, and their air power all but finished. And major cities throughout the country were flattened by B-29s to the point that military historian F. J. Bradley argues that by August 1945 "there were no strategic targets left." So how would this war end? American casualties for the invasion of Kyushu were projected to be 22,576 killed, wounded, and missing during the first 30 days. For every ten additional days another 11,00o would fall. The attack was scheduled to begin on November 1. President Truman made the call. The invasion would be put on hold and Japan would feel the heat of the atomic bomb, first dropped on August 6 . 
Japanese newspapers did not carry any details of the atomic bombings, thus most people had little knowledge of or response to them. While rumors spread that some new type of weapon had been used against Japan, to those outside the two cities, Hiroshima and Nagasaki, little was known. "No one used the words atomic bomb," remembers Masaaki Yano. "We just heard there was some new type of high powered bomb. It was after the war I heard it was an atomic bomb." Yoshio Ninomiya heard something about a special bomb exploding in Hiroshima, but, like Masaaki Yano, he had never heard of an atomic bomb. "Even our teachers probably didn't really know anything about it; at least, they did not talk as if they did." In Usa, located in the northern part of Oita and closer to Hiroshima, some recognition of the danger posed by an atomic bomb emerged. Takafumi Yoshimura remembers, "We heard that a powerful bomb had dropped on Hiroshima and, all of a sudden, students were told to stop wearing dark clothes and change to white. Someone said white clothes don't absorb radiation as much as black clothes, so we changed into white."

Former prime minister Murayama had left his Oita home late in the war when he was conscripted. He was stationed in nearby Kumamoto at the time of the first atomic bomb.

I was in Kumamoto when the news about the nuclear bomb in Hiroshima came. At the time, no one knew anything about atomic bombs, so it was only called "a very bright light." If you were in the light, you'd get seriously injured. That was how the troops were informed. During the Kumamoto bombing, the troops hid in the mountains that surrounded the city, so we had little information on the Hiroshima bombing. But, privately, we did wonder, "How can we fight a war under these circumstances?"

Nobuo Kawamura, the Oita school teacher pressed into service near the end of the war, served in Kokura, just north of the Oita Prefecture border with Fukuoka Prefecture and about 100 kilometers from Hiroshima. He remembers:

On the $6^{\text {th }}$ when Hiroshima was hit, I was in Kokura. It was too far away for us to hear or see it, however. The officers informed the soldiers that a new type of bomb exploded in Hiroshima. The soldiers were ordered to put on our long-sleeve shirts. In addition, when sirens went off, we were to wear our full suit. On August 9, at around 11:0o, a call came that the same bomb was dropped in Nagasaki. We found out later that Kokura, where I was stationed at the time, was the initial target. It just so happened the 
city was shrouded in clouds and the target not visible that day, so the Americans went with their back-up plan and hit Nagasaki.

One young man from Oita did witness the bombing of Hiroshima at close range. He tells what he saw while training as a youth naval cadet.

I graduated from middle school in March 1945. Rather than going on to high school, I volunteered to enroll in the naval school on Etajima at age sixteen. The island of Etajima was just off the coast of Hiroshima, and I saw B-29s flying over on a regular basis. We studied English, math, physics, and Japanese in the morning and learned how to steer a boat, how to shoot, and other military skills in the afternoon. Furthermore, we swam in the sea every day as part of the training. One morning, as we were walking to the ocean from school, we saw what looked like a lightning bolt coming from Hiroshima. The explosion sounded like thunder, and raised a mushroom cloud. When we got back to the school and inquired what the bomb was in Hiroshima, no one knew it was an atomic bomb; just that it was a new type of bomb. We were ordered to cover our arms with stitched socks to protect ourselves from getting burns. For days after that, we'd pull them on at the sound of the air raid siren. Nevertheless, we kept on training, even going back to the sea in the boats. But we did not go swimming again.

After the war ended, we were let out of the school to go home. I boarded a ferry to Kure. From there, I'd take a train along the coast toward Oita. It was after nightfall when we left Etajima. When the train passed through Hiroshima city, I could see very little of the destruction. But I definitely noticed that there were no longer buildings against the skyline. It was a horrible hollow feeling. Luckily, even though I was close to the explosion, I never experienced any radiation sickness, nor did my classmates. We saw the explosion but escaped injury. ${ }^{3}$

When the bombing of Hiroshima elicited no Japanese response to American calls for surrender, the Americans decided to bomb Nagasaki on August 9. Chief of Staff General George C. Marshall explained a few years after the war that Truman hoped Japan's leaders would be "shocked into action" following these bombings. The devastation from the Hiroshima bomb was quickly grasped in Tokyo by those few with access to the truth, but it took two days before the emperor even ordered the cabinet's chief bureaucrat to 
draft the Imperial Rescript Ending the War. Despite the follow-up bombing of Nagasaki, it took three additional days before the draft was sent to the prime minister's cabinet, which modified it before finally approving it for transfer to the emperor. On the night of August 14 he signed it. ${ }^{4}$ All the while, the three military leaders from Oita advising the emperor resisted the obvious.

In his Oita headquarters, Admiral Ugaki never stopped planning for massive resistance, despite the expected toll this would take on the people. The citizens in Oita were mobilizing and knew little or nothing of the heated discussions taking place in Tokyo nor the most recent catastrophic events befalling their country. They just waited and watched the skies for more American planes and scanned the coastline for invading American soldiers. 


\title{
14 We Didn't Surrender - The War Just Ended
}

\section{The Emperor's Voice}

During the 20 days between the Potsdam Declaration demanding unconditional surrender and the end of the war on August 15, 1945, the emperor and his advisors struggled with how to stop the war and maintain Japan's dignity. Throughout this time the bombing of Japanese cities continued unabated. Oita felt the blasts until August 11. During those two weeks of bureaucratic dithering, an estimated 380,000 Japanese died. One Oita historian writes, "Had they [the Japanese leaders] accepted the Potsdam Declaration to begin with, this could have been avoided. It is a 20-day tragedy."

Then, the world changed on August 15.

\begin{abstract}
All morning, the radio kept broadcasting that the emperor was to make an important announcement at noon. On this particular day, the weather was wonderful across the entire nation. Oita's skies were blue and the summer sun shone brightly. As it approached noon, citizens gathered around whatever radio they could find. Even at this point, the populace still believed that their blessed nation was invincible and that it was inconceivable that Japan could lose any war. Many people actually expected the emperor to encourage them to keep fighting, to fight harder. It was noon. After the national anthem, the emperor's voice came on. No one had ever heard his voice before. "Upon reviewing the situation between the world and our empire, it is with grave...." The radio signal was so bad; people had a difficult time understanding what the emperor was saying. Some people even thought it was a call to arms for a battle on mainland Japan. However, what little many of us could understand made it clear we'd lost the war. People started to cry and moan in pain. ${ }^{2}$
\end{abstract}

As the morning of August 15 broke, student factory workers went about their business as usual. In Saiki, fifteen-year-old Kou went to work in the navy shipyard as he did every day. "We were ordered to gather in an open space to listen to a recorded announcement by the emperor. When I heard we had 
to gather for the emperor's speech, I expected to hear the war was over." This youthful insight into the coming end was not shared by most other young people. Twelve-year-old Yoshio Ninomiya loaded the rocks by the river into the truck as he did every day. Heading home after work, he recalls, "someone in a small store had a radio playing and that was how I listened to the emperor's talk. But I did not quite understand what he said. When I got home, I saw my father crying. It was a sad scene. He told me Japan had lost the war and now it was over. I couldn't believe it because I thought Japan was still winning. But at the same time I felt relieved, although I couldn't tell anyone how I felt at that time."

Takafumi Yoshimura in Usa recalls:

It was during summer break, and I went to the store on an errand for my family. I remember being surprised that for the first time in a long time there were no air raid sirens going off. When I got to the store, the radio was on, and a lady was crying. She told me she'd just heard that Japan lost the war. My family didn't have a radio, so I'd not heard the speech. I couldn't accept the fact that Japan lost because I'd always been taught Japan would win the war. I was really confused. I'd planned to become a soldier. My parents were farmers, but I didn't want to be a farmer. Being a soldier was my path out of farm life. What was I going to do now? I had to think what I should do next.

Ichiro Hashimoto was in a protective tunnel working on airplane engines when the announcement came.

I remember the radio announcement at noon. I don't know if they did a bad job recording his message, but the announcement was not clear. We couldn't tell if he was saying, "Keep it up!" or "Give up." It took a while to find out that the war had actually finished. We went back to school after that, and the teachers told us the war was over and that was it. They didn't say Japan had lost, only that the war was finished. They didn't show much emotion, and, as I was still just a kid, I didn't know how to feel. I remember I didn't feel much, though.

Masaaki Yano was working in his bomb-making factory in Oita City when the students were told to stop and listen to a special announcement on the radio. "I heard that the war was over and knew that the United States had won. I didn't think much about the future of Japan. I was just looking forward to going back to school and hoped the teachers would not hit me anymore." 
Tetsuo Tsukuda, hearing of the war's end at school, recalls a similar sense of relief, "I felt happy, even though we lost. Maybe we could have enough food now, I thought."

\section{Poison for the Women}

Women had particular concerns in the days following the surrender. Tsuruko Tomonari was working alone in her maternity clinic in Beppu when she heard the emperor's talk. "It was about noon when I heard the speech. I could not believe that we'd lost the war. I cried alone."

In Oita, Nobuko Eto was working in her hospital when she was told to go with the other nurses and doctors to the office to hear an important announcement. But this headstrong girl refused to leave her station. "We were so busy in the hospital treating injured people I didn't have time to listen to the emperor's message. Later, my friend told me that the war was over and that we had lost. Those were the only words I heard, and my head went blank. It was so depressing." Nobuko and her friends were told that the Americans would come soon. Before leaving the hospital that day, the pharmacist handed her a crumpled piece of red paper with powder inside. "If something happens," he said to her, "take this." It was poison.

Nurse Yukie Matsumoto, the young woman so proud of the stylish uniform fashioned by the empress, spent the last days of the war treating those injured by bomb attacks around Kagoshima in southern Kyushu. As soon as the doctors and nurses heard the war was over, everything changed. They wasted no time leaving the makeshift military hospital.

Those of us from Oita started to walk home. Before leaving, we were told that American soldiers were landing soon, and if they found us we'd almost certainly be raped. A doctor gave each of us a syringe filled with poison. We were to use that before being captured. It took us two and a half days to get home, but we didn't run into any problems. I kept the poison for a long time, but now I don't know where it is. It's been sixty years, and I'm guessing it long ago lost its potency anyway.

\section{Defeated and Sent Home}

Those serving in Japan's military heard about the end of the war at different times in locations scattered across Japan and the Asia Pacific region. 
Captain Morimasa Yunokawa, the kamikaze officer who had trained his pilots in Usa and Oita, took the news hard.

I was at Komatsue training to use the new Oka 2-2s for kamikaze attacks. I had heard the day before that the emperor was to make an announcement. So I gathered my men around the radio and we listened but we could barely make out the words because the quality was so bad. We knew immediately that the war was over; we just couldn't make out the exact words.

I gave a speech to my subordinates. I said that we all heard what the emperor had to say. It seems the war is over, but I don't know what's really happening. A lot of men have died fighting this war, and for what? This may be the emperor's real desire, but it may also be what some people surrounding the emperor forced him to say. Therefore, we must assess the situation closely before taking any action. We don't want to make any mistakes. Stay calm and wait until the situation becomes clearer. Three days later, on the $18^{\text {th }}$ of August, the troops were finally instructed with clarity regarding the real situation and the plan of action. I finally accepted the defeat. On August 21, we received our final paychecks, and I sent my men home. The officers had a final dinner together. I'd already decided that I would commit suicide. I'd trained and sent so many men off on their suicide missions. All the while, I'd been told to fight harder. What a complete reversal this was. ${ }^{3}$

Captain Yunokawa, who had earlier been saved from death on March 18 in Usa when American fighter planes shot up his kamikaze command, was saved yet again, this time thanks to his own commanders. He was preparing a pistol to shoot himself when his superiors entered the room to intervene and give him one last important and secret assignment, one a loyal follower of the emperor could not refuse. As told by his biographer:

As he was preparing to put a gun to his head, a secret message came from Naval Headquarters ordering him to join in a mission to save the emperor. No one knew if the emperor was going to be executed.Japanese have long believed that the lineage of the emperor must be preserved and protected. So, the idea was that even if the emperor was executed, his family must be protected. Being a respected, trusted and capable officer, 
Captain Yunokawa was chosen to carry out this mission. He accepted the assignment. A fiction was created that Captain Yunokawa had gone on a kamikaze raid and died in action. He went underground, like a spy. Under a false identity, Captain Yunokawa moved to Shimane Prefecture and started a new life in a totally strange place. He chose that location because no one knew him there. He told people that all his family had died in Hiroshima, and he was alone. After five months he received a message that the emperor and his family were safe, and he could come out of hiding. It was in Shimane that he met his future wife, under his assumed name. He soon returned to his home close to Tokyo to live with his new bride under his real name. ${ }^{4}$

Another kamikaze pilot who survived the war was Kiichi Kawano of Oita. He was scheduled to take off on his mission on August 16. He had seen his friends fly out on the days and hours just before the emperor's speech and had every intention of joining them.

One of my good friends was Yoshiomi Nishimori. On August 13, right before departing on his mission, he called me over to his room and asked me to exchange uniforms with him. "Why should I exchange uniforms with you?" I asked him. "I'm going to die in three days, too!" He said that he was going to die before me, and that he wanted to die in a newer and cleaner uniform. Since he was my senior, I agreed and exchanged uniforms with him. When I went home after the war I was actually wearing his uniform. I think it was a blessing from god that my uniform was sacrificed in the war instead of me. For many years after the war I looked for his family to return his uniform to them, but I could not find them. He was originally from Kochi, and they built a museum there to commemorate the war, so I donated the uniform to the museum.

On the $15^{\text {th }}$ another friend of mine flew out on his mission at 11:00 a.m. Then, at noon, we were ordered to listen to the emperor's speech. After I realized the war was over, I hoped my friend would turn back, but he never returned home. That day I thought to myself how unfortunate I was not to die. Those who died were the lucky ones. At that time we were so uncertain how Japan would turn out. It was a very twisted time.

4 Interview with Yuko Hada, Tokyo, July 11, 2012. The existence of a secret mission to protect the emperor is supported by comments from Imperial Guard Isematsu Matsumoto and his wife, Yukie, during an interview of February 25, 2012. See the following. 
Isematsu Matsumoto, serving in the Imperial Guard at the palace in Tokyo, gathered with his fellow guards to listen to the radio message from the emperor.

We were in our barracks just outside the palace. When I realized what he was saying, my chest tightened and I was crushed. The guard unit was dismantled right then and there. Some younger guys who weren't officially military were hired to protect the emperor. A rumor circulated that one certain commander and some of his buddies tried to organize a secret force to protect the emperor and maybe overthrow the government. They didn't want to give up the fight. This wasn't a formal or sanctioned organization, just a few commanders who decided to do this over drinks. I found out soon that these rumors were true, as one of these officers said that he might contact me later to continue the fight, and it could take up to five years before he'd send me my orders. I understood, I said, and finally, on September 7, we were all dismissed and sent home.

While I waited for the train to take me back to Oita, I saw my first American jeep. The American soldiers came into Tokyo, and they took pictures of us. Would I be secretly ordered to fight them again? For the next five years, I was often anxious and dreaded hearing from that officer. Thankfully, he never contacted me. ${ }^{5}$

Most soldiers serving in Japan found out about the emperor's talk after the civilians had heard it. "I didn't hear the emperor's speech, because I was busy with my army duties. We heard the news a few hours after the radio announcement from our superiors. At first I felt bad that we had lost, but some of us were at the same time relieved because it was a long time coming," recalls former prime minister Tomiichi Murayama.

As soon as I found out the war was over, three friends and I headed home together. We just left. About ten days later, we received a letter from Oita City Hall, telling us to go back to our base in Kumamoto. The army had not yet been dissolved. Since we had left without authorization, we were reprimanded for having abandoned our duty. Rules are rules, the army always conducts things properly. So we went back, but as there was nothing to do, we were finally discharged. No speeches, no encouragement, we just left and were free.

5 Matsumoto believes that it is possible, though difficult to verify, that this order was under the same secretive leadership as that which ordered Captain Yonakawa to go underground. 
Mamoru Hirano worked as a noncombatant army technician in the airplane-maintenance factory preparing kamikaze support planes for their missions.

It was right before I was to transfer to another location, since we followed the airplanes to wherever they were. I packed up all of our tools and got on the train when people asked us what had happened. We had no clue but soon found out that the war was over. I knew the situation wasn't going in our favor, despite the good job done by the kamikazes. I guess I was relieved that it was finally finished, but I couldn't say that to anyone at the time. We couldn't really speak those words even then.

Nobuo Kawamura was stationed in Fukuoka, about 100 kilometers from his hometown of Oita, when the war ended.

I didn't hear the emperor's speech. A lot of people heard the announcement, but many of us in the military didn't. It's not like we had radios lying around in those days. We found out by a telephone call from headquarters, ordering us not to make a move, no explanation, nothing, so we didn't even know that Japan had lost the war. When we finally realized what happened, I was actually happy. I'd known for a while we couldn't win, but I could never have said that. Some of the career soldiers in our unit ran away, because they thought they'd be captured and executed when the Americans came. Most of us weren't career soldiers, and we were just happy to go home to our families.

Those soldiers fighting overseas found out the war had ended over a period of weeks, depending on their assignment. The Oita $47^{\text {th }}$ Regiment was stationed in Indonesia when the war ended; many isolated on small, out of the way islands. Captain Shukichi Make was one of them.

I was in Timor, on Sumbawa Island with my men when the war ended. On the morning of August 15, we got a phone call to let us know what had happened. My first thought was this was a joke, some kind of plot. When I fully realized it was true, I cried, as I'd spent seven years with my men, and I felt sorry for them. I tried to figure out why we'd lost. We waited fifteen more days to get our orders. On August 31 members of the regiment who were nearby gathered around our headquarters and one of the captains burned our regimental flag. When the Australian Army took control over Timor, they ordered us to bring in our weapons 
and gunpowder to a designated location. But, because the territory was so big, and the Australians could not manage everything, they finally instructed us to decide on our own how to dispose of our weapons and ammunition. We took the gunpowder and dumped it over a cliff. We stayed in Timor for another year, living off the land as best we could. The Australians didn't provide us with any food. We cultivated bananas, corn, and vegetables. In that climate, things grew fast. We also planted rice. We didn't get home until June 1946.

Jiro Nakano, the young naval wireless operator from Beppu, ended the war in the city of Makassar in South Sulawesi, Indonesia. At the end of the war he was a navy petty officer, $2^{\text {nd }}$ class. He was in his company's headquarters attending to the wireless machine on August 15 when he received the telegraph message about the end of the war.

I couldn't believe the message I'd just received. After I told the other men in the room we all went crazy, throwing things around the room and screaming that this could not be true. But it was true, and we had to accept the fact. The communications unit was sent to a POW camp at Malimpung along with other navy and army units. I was ordered to stay there and take charge of handing over weapons, including my wireless, to British Indian Army soldiers. My gun was taken away, but I stood guard over the equipment. Before the war ended, the local Indonesians and Chinese had greeted us with "Good morning, sir." Now that they saw us as unarmed prisoners, they'd spit on us. We stayed in Indonesia for almost one year before returning to Japan in June 1946.

Sergeant Naomasa Kodama of the $47^{\text {th }}$ Regiment was almost completely isolated on another small island near Timor.

The $47^{\text {th }}$ Regiment was separated into nine groups, and mine was number six, with about 200 men. There was little contact among the groups. I didn't know the war was over until sometime in October. For two months we received no communication from anyone. When we were finally contacted, the war had been over. Before leaving, we threw our guns into the ocean. In my mind, we did not lose. Japan never surrendered - it was just that the war was now finished. 


\section{Ugaki’s Pride}

Three hours after the emperor told his people that Japan would put down its sword, one final, dramatic sortie on American forces took place. This unsanctioned kamikaze attack originated from the naval air base in Oita City and was led by Admiral Matome Ugaki. This was the same commander who had helped prepare Japanese forces for the first attack on the United States base in Pearl Harbor from the Oita town of Saiki four years before, and who had been entrusted to coordinate the defense of Kyushu during the anticipated invasion. The story is introduced here by Hideo Sonoda who was one of the young pupils, working in the factory that prepared the planes for kamikaze raids out of Oita City.

Some of us were resting, listening to the emperor's announcement, when, all of a sudden, someone yelled, "Get up! Get Up! Now! We're going for a final attack. The commander is going for one final attack! Go make the bomb attachments now!"

We rushed into the factory and, for the next two hours, attached bombs underneath the planes. We knew the war was over, but we had no choice but to help get the planes ready. Our job was making parts to hold bombs, so we did that. It wasn't our place to question anything. We had to obey orders. I don't know how the kamikaze members felt, but my guess was no one was against going. Their leader simply said, "I'm going!" and they said, "Then we're coming with you!"

Admiral Ugaki had heard the emperor's message, and wrote the following in his final diary entry before he led the attack.

There are various causes for today's tragedy, and I feel that my own responsibility was not light. But, more fundamentally, it was due to the great difference in national resources between both countries. I hope from the bottom of my heart that not only military men but all the Japanese people will overcome all hardships expected to come in the future, display the traditional spirit of this nation more than ever, do their best to rehabilitate this country, and finally revenge this defeat in the future. I myself have made up my mind to serve this country even after death takes me from this earth. Now at 1600 my staff officers are waiting for me to drink the farewell cup, so I'm going to end this war diary. ${ }^{6}$ 
The admiral then drank his last cup of sake with his staff at $5^{\text {th }}$ Air Fleet Headquarters and headed for Oita airfield by car. In his hand he held a short sword given him years before by Admiral Yamamoto. When he got to the field he saw 11 Suisei dive-bombers warming up their engines, with 22 airmen lined up in front of them, for each plane carried a crew of two. On each man's forehead was the traditional Kamikaze head band with the red sun in the center. Surprised to see so many join this final attack, for he only ordered five planes to accompany him, Ugaki asked, "Will all of you go with me?" They all shouted, "Yes, sir!" and raised their right hands in unison. Ugaki thanked them all, bade farewell to his staff and boarded his own plane, which held him, his first officer, and one other man who insisted on squeezing in. The planes took off one by one, disappearing into the sky as they headed south to Okinawa. His last message displayed the traditional Japanese warrior spirit that ignited this war, and which could not accept defeat without the final sacrifice.

Despite brave fighting by each unit under my command for the past six months, we have failed to destroy the arrogant enemy in order to protect our divine empire, a failure which should be attributed to my lack of capabilities. And yet, believing that our empire will last forever and the special attack spirit of the Air Force will never perish, I am going to proceed to Okinawa, where our men lost their lives like cherry blossoms, and ram into the arrogant American ships, displaying the real spirit of a Japanese warrior. All units under my command shall keep my will in mind, overcome every conceivable difficulty, rebuild a strong armed force and make our empire last forever. The emperor, Banzai! Time: 1924 . 15 August 1945. From on board plane. ${ }^{7}$

What happened next remains a mystery. One American military historian reports that late that night radar from an American base in Okinawa registered a group of incoming planes. Night fighters on routine duty rushed to meet them and, after verifying they were not American, proceeded to shoot them out of the sky without any damage to American planes, ships, or ground forces. ${ }^{8}$ Local Oita reports insist that Ugaki crashed on the small island of Iheyajima, on the northern tip of Okinawa, and that no American targets were ever hit by him or his fellow kamikaze. 
American reports say that none of the 22 airmen returned to base. They all died. However, that is clearly not the case, as several Japanese reports claim that three planes returned with five airmen. (It appears one of the men died during the flight.) Over the years some of these men granted interviews to tell their side of the story. Their planes were too weak to make the trip due to engine failure, so they turned back before reaching Okinawa.

Conflicting views on the patriotic and spiritual merit of this attack have been debated since the end of the war. Just before leaving, some of Ugaki's own officers tried to talk him out of it, while others then and later glorified it as a noble example of honoring the emperor and upholding Japan's warrior spirit. From another corner of Japan comes the view from kamikaze Captain Morimasa Yunokawa. He had served under Ugaki at one time and knew the admiral's character well. While not surprised at his action, Captain Yunokawa argues that he and most others within the military looked upon Ugaki's last action with disgust. "It was shameful what Ugaki did. Many fine officers in the navy detested his action. This was totally uncalled for; the war was OVER. Many, including Ugaki's Commander Jisaburo Ozawa, were mostly angry with him for not just taking his own life, but that of others as well. I went to the Naval Academy with some of those men he took with him. He should have committed harakiri instead." ${ }^{\text {9 }}$

\section{Oita Men on the Missouri}

The final and formal ending of the war took place in Tokyo Bay on September 2, 1945, aboard the battleship USS Missouri. The emperor sent two representatives to sign the surrender document. One was Foreign Minister Mamoru Shigemitsu, who had been reappointed foreign minister only on August 17. The emperor hoped Shigemitsu would prove a conciliatory choice, as at least within Japan he was known as more amenable to ending the war than some others. The other was the chief of staff of the Japanese Army, General Yoshijiro Umezu. Ironically, the emperor ordered Umezu to represent the Japanese military at the very surrender that he had resisted as a member of the War Council in the days leading up to the end. These two men grew up in Oita Prefecture only a few kilometers from each other, one from Kitsuki and the other from Nakatsu. Thus the two Japanese signatures affixed to the formal surrender document on the battleship Missouri were both Oita men. 
During those many years of war throughout Asia and the Pacific, the quiet but strategically located Oita Prefecture played a role no one could have imagined prior to 1941. Supreme military leaders, foot soldiers, and airmen helped lead the way in many battles in China and throughout the Pacific. The prefecture had served as a primary training center for the first attack of the war on Pearl Harbor, and four years later the staging ground for the final kamikaze attack. It held many important air and naval bases, and by war's end Japan's foreign minister and three of the six most important advisors to the emperor called Oita home. Finally, the capstone of the prefecture's historical role is that it fell on two Oita born men to sign the surrender document for Imperial Japan.

One is struck by how much one small place contributed so much to such a horrific period in history. 


\section{Hungary, Confused, and Afraid}

\section{Waiting}

Japan began to change dramatically as soon as the emperor's speech ended. The Oita Godo Press, for example, transitioned literally overnight from a war rallying platform to a peace-filled gazette. The August 16 edition wasted no time in explaining to a confused people why the war had to be stopped. The lead story, under the title "Imperial Rescript Declaring the End of the War Appreciated," extolled the emperor's "quite exceptional" announcement outlining the agreement to accept conditions laid out in the Potsdam Declaration. "Although Japan had intended to establish a peaceful world through this war, the situation for Japan deteriorated day after day, culminating with the great number of innocent people sacrificed by the atomic bomb. If we continue the war, our nation and civilization will become extinct." It exhorted all citizens to heed the emperor's words and rebuild the country with "full and collective efforts."

But in reality the people were hungry, confused, and frightened. Throughout the country these three realities quickly overwhelmed the lives of most people. Food shortages had been building for the final two years of the war, but government subsidies, together with small but vital production of rice and vegetables in the countryside, kept starvation at bay. This was the physical pain to bear. Confusion arose from the shocking news that Japan had lost the war. While high-ranking officials and even mid-level military officers had seen the futility of continuing the war, none dared say so aloud, so civilians were not aware how thoroughly Japan had been beaten. Widespread anxiety and fear arose as they waited for U.S. soldiers to march into their country, changing their way of life, and raping their women.

\section{Occupation Plans}

Unknown to the people of Japan, including the military leaders who had taken their people into this disaster, American strategists had begun a detailed plan to occupy the country well before the surrender. "Top Secret" plans of action were written, debated, and readied for implementation by the Joint War Plans Committee and submitted to the Joint Chiefs of Staff 
even as the Battle of Okinawa raged on. By now, despite the continuing slaughter, the eventual victory was not in doubt, only the time it would take to occupy the country. One of the early occupation plans from May 1945 opens with the rational for preparation:

1 The possibility exists that Japan, realizing that defeat is inevitable, may surrender at any time in an effort to obtain the best terms possible and in order to avoid destruction of her homeland. In the event of a surrender or collapse, or of withdrawal from occupied territory, the Allies must be prepared to occupy such strategic areas as are necessary to enforce their demands and insure the peace. In order to be prepared for such an eventuality, the strategic areas to be occupied and the forces and resources necessary for Occupation must be determined.

2 It is the intent of this study to establish a priority list of such areas or positions. Such a list will remain reasonably firm. The forces and resources required for Occupation will vary with changes in enemy dispositions and capabilities, as will Allied resources available for Occupation. These matters should therefore be the subject of continuing studies.

The locations were prioritized according to the following criteria:

a The present political, military, and naval subdivisions of Japan

b Japanese commerce and industry, particularly with regard to foodstuffs

c Population centers

d Locations of prisoner of war and internment camps

Areas were prioritized in three categories. The top-priority areas were to be occupied immediately "as the minimum necessary to gain and exercise military, political and economic control." The second tier would be occupied "to secure firmly the first priority areas or because they are themselves essential to a lesser degree." The third-tier areas were considered of less importance, to be occupied "after first and second priority areas and when forces become available."

Clearly the first priority was the region of Tokyo and Yokohama, the center of Japanese war making orchestrated by military, civilian, and imperial powers. Other primary areas included the industrialized ShimonosekiFukuoka area, as well as Osaka, Kobe, and Kyoto. The second priority area included Nagoya, with its massive military installations and suspected prisoner of war camps. Hakodate, Sasebo, Nagasaki, and Hiroshima were also on this list.

Finally, the third category of areas to be occupied included 29 cities and regions. Of these 29, the Oita-Bungo Channel Area, with Oita City on one 
side of the channel and the nearby island of Shikoku on the other, were listed as the fourth most important location to occupy in this third tier. The rationale for occupying this area was spelled out briefly in the report:

\section{Oita-Bungo Channel Area ${ }^{2}$}

a Military considerations. This area includes: Air center at Oita:Hoyo Fortress (Bungo Channel)

b Economic considerations. Aircraft assembly plant; several large cement plants; important copper smelter at Saganoseki. Oita is a junction of the Nippo main line and cross-island lines; good yards and shops. Radiotelegraph and broadcasting.

c Political Consideration. Oita is the capital of Oita prefecture. Population of the area in 1940 was $200,000 .^{3}$

As this report was prepared, war still raged in the Pacific, Hiroshima had not yet been targeted for the first atomic attack, and both sides prepared for a brutal invasion and resistance in the coming months. On the American side, the detailed analysis of the coming occupation was interspersed with awareness of the unknown, coupled with a profound fear of a crazed populace that could not be trusted. A May 16, 1945, report from the Joint War Plans Committee issued the following warning:
Although the exact conditions which will exist in Japan at the time of collapse or surrender cannot be predicted, it is probable that the presence of an Occupation force will be bitterly resented. This fact, together with the inherently treacherous nature of the Japanese, make it mandatory that the Occupation force in each area be in sufficient strength to insure adequate defense of installations and communications, and effective control of the local populace.

The Americans were eager to take control of Japan, and they would brook little interference from anyone, not even their allies. A June 25, 1945, report states:

2 The Bungo Straits, between Oita Prefecture and the island of Shikoku, were considered one of the most dangerous areas for American submarines and other warships to enter for most of the war. It was made famous in the 1955 film Run Silent, Run Deep, starring Clark Gable and Burt Lancaster.

3 "The Occupation of Japan, Part 1, U.S. Planning Documents, 1942-1945. Military Planning for Defeat and Occupation of Japan, 193-1945, Section 4-C-1 to 31." Sections 4-C-1 and 4-C-2, May 16, 1945 . 
The United States has carried virtually the entire burden of the war against Japan in the Pacific. In order to assure adequate post war control in Japan and because we shall require post war control of broad areas in the Pacific, our national interests demand we maintain a dominant role in the post defeat period. For this reason the initial Occupation of the main islands of Japan, Formosa, Nansei Shoto and Nampo Shoto should be undertaken by U.S. forces. Regardless of the ultimate composition of Occupation forces as established by international agreement, the inclusion of Allied forces (except for minor elements) in initial Occupation forces would likely lead to unacceptable interference with operational plans.

The report goes on to identify the locations the Allies expected to occupy, with the United Kingdom focusing on Southeast Asia, the Soviet Union (if they declared war on Japan before the end of the war) the Kuriles and Karafuto (Sakhalin), in addition to already agreed upon Manchuria and north China. Chinese forces were expected to control all of China, apart from Manchuria and parts of north China. ${ }^{4}$ The plans for the postwar period were nearly ready. On July 26 the Joint War Plans Committee indicated with uncanny accuracy the expected date of surrender, as seen in this section of the report subtitled "Assumptions":

Japanese resistance has collapsed or the Imperial High Command has surrendered unconditionally (1) about 15 August 1945, or (2) about 15January. In isolated instances, local commanders will continue to resist and acts of sabotage and treachery on the part of local Japanese population will occur.

The plan envisioned that, upon collapse or surrender, an order would be issued to the Japanese Imperial High Command requiring the following actions:

1 All Japanese forces except police were to remain in present position, to be disarmed and all arms turned in to the occupying force.

2 Within 48 hours, lists of all military bases, their locations and strengths must be provided, including all aircraft, naval vessels, minefields and prisoner of war camps.

3 All military vessels and aircraft were to remain in their current location undamaged.

4 All mines, minefields and other obstacles to be removed within 14 days.

4 "The Occupation of Japan," Sections 4-C-5 and 4-C-6. Manchuria was considered a separate entity at this time, with a confused status. 
This plan anticipated that American troops removed from Europe after the recent surrender of Germany would be redeployed for Occupation service in Japan. If the war ended on August 15, it was expected there would not be enough available forces to occupy the island of Kyushu, which included Oita. Therefore, the most likely scenario envisioned mid-January 1945 for the initial Occupation force to land. 5

While Americans planned their Occupation, the people of Oita, under constant attack from the skies, could not imagine they would be occupied. Their leaders, through the tightly controlled media, continued to extol them to sacrifice and to work till exhaustion for victory and to prepare to die. Then, as projected by U.S. intelligence, the emperor's speech of August 15 ended the illusion of victory and lifted the immediate threat of dying for the emperor while fighting an invasion force of American soldiers. But what was to come? Death in another way? The raping of Japanese women by American soldiers? Subjection to a foreign force, losing their own right to be Japanese, making Japanese decisions, and living in traditional Japanese ways? They waited, knowing nothing of American intentions.

\section{Running to the Hills}

Having no idea when the first American soldiers would arrive, Oita residents dreaded every day. Of course they did not know that Oita was a third-tier Occupation site. Some panicked. The first response, especially for the women, was to run away and hide. Unlike those nurses with easy access to poison, most had little time to find doctors or pharmacists to provide them this quick escape from the American rapists. They only had their wits and their legs. Yonosuke Yanase recalls what happened in his home.

The most uncertain period was from the end of the war on August 15 through the end of August. The citizens received no clear information during those fifteen days. Rumors ran rampant that the Americans were coming into Beppu Bay at any time. People were scared out of their wits imagining what the Americans would do to women and children. So they arranged to send the women and children into the mountains. On August 20, at 8:00 in the evening, my two sisters, my mother, and a neighbor left for Ajimu, about 50 kilometers away from our home. We packed as many kimonos and personal belongings as they could carry 
and sent them on their way. They walked all the way, nonstop for ten hours. They had no flashlight, and it must have been very difficult to see where they were going. They told me later that they were really scared, not that the Americans were coming, but the road was really dark and really terrifying. They cried all the way. My oldest sister was seventeen and the other one fourteen. Just as they arrived in Ajimu the next morning, they heard that everything was going to be OK and that the Americans had not come and wouldn't come for a while. They turned around and headed back home the next day. Again, they walked all the way back to Beppu without stopping.

A similar story is repeated by 99-year-old Masako Ono, who shared the following:

Right after the war, there were lots of rumors that the Americans were coming and what they'd do to women. Many people worried what would happen to them, so some of my family and friends ran and hid in the mountains, some for three days, others for a week. I was already a married woman, so I stayed, but sent my unmarried daughters to the countryside. They came back after we heard there was nothing to worry about, that no soldiers had arrived.

\section{Bartering for Food}

As a student laborer in the military factory in Oita City, Ichiro Hashimoto made torpedoes in the days leading up to August 15. Now that the war had stopped his family fretted and watched. As rumors spread that Americans were on the verge of entering the city, Ichiro and the rest of his family hurried into the surrounding mountains where they had family and friends. "Eventually we heard that there was no danger and that no Americans had arrived yet. We returned home in one week, though some people didn't come back for a long time. They stayed away not only because of the fear of the Americans, but also because there wasn't much food in the city and they thought living on a farm would be better."

In Oita, a relatively poor region of Japan to begin with, one that had poured so many resources into the war effort and where much of the infrastructure was demolished by American bombing, this was certainly the case. Memories of those times remain painful. People sold or bartered what they could to get food, from clothing, to sea salt, to family heirlooms 
of rare fine art and antiques. Rice was the most sought after commodity, with wheat and soybeans next. Vegetables were desired, but rarely available. Some people fished, and others went foraging in the fields for wild, edible roots and berries. School grounds were converted from sports and recreation centers to gardens, as children planted potatoes, each child receiving a small share when they were harvested.

Toyoki Goto says it is still "very difficult" to conjure up his thoughts from that time.

We watched the Americans when they finally came into Oita. But, to be honest, we didn't pay much attention to them. We weren't concerned with what they were doing. We were only concerned with ourselves, wondering if there was any thing to eat tonight and tomorrow. My father had died, I was too young to earn an income, and my family was hungry. It was ridiculous. Sometimes, we'd have only one sweet potato for the whole family. What little rice we could find we grounded into powder and made a paste out of it. Hunger lasted for years after the war, though got better slowly as Japan's economy recovered bit by bit.

Nobuko Takahashi remembers:

During much of the war, especially toward the end and then during the Occupation, there was little food for city folks. My mother and I would take her kimonos to the countryside to barter for food. There were two types of kimonos, the common daily wear and the more expensive and stylish wear used for weddings and festivals. The common kimonos were more popular with the farmers. We had no way to get there except to walk. So we'd just pack up the kimonos, carry the bundles on our backs or on our heads and walk until we found buyers. It was the women's job to get the food, because men wouldn't sell kimonos to farmers. I don't remember how much rice we got for each kimono, but it wasn't much. Each family would just take one or two kimonos. It was all a matter of supply and demand. Thinking back, those farmers were not very nice people. They stockpiled the kimonos to sell later, and many got rich off us.

Nobuko Takahashi's attitude was not an isolated case. Some in the countryside felt little kinship with city people, especially in transactions that were just business deals with strangers, and not their relatives from the city. Growing up on a farm, Hideo Sonoda seems to relish a bit of payback to the city folk, who had lived more comfortably for years before and even 
during much of the war, while farmers worked every day to tend their crops. Perhaps it was their time to lord it over those from the city. He recalls:

My family was farmers, so we weren't particularly strained for food during and immediately after the war. Our entire family would work in the fields. I had done it since elementary school. I'd always work in the fields and never played with my friends. Even during spring break and summer vacation, I'd take a bento and work in the fields all day. The city kids, at least during much of the war, had time to play and enjoy their vacation while I was working. Now, when food became really scarce in the city, they had to come to us to for food.

Hidekatsu Nakano says that in his family, city buyers and countryside sellers felt no ill will, at least from the perspective of a small boy watching them come up to his home. In part this was because many of those in need were family and friends.

The city people would bring salt and kimonos to exchange for rice. I don't remember much about how we used the kimonos, whether we sold them or kept them, or how much they were worth, but salt was more important for us, because we pickled so many things. Some of the people were our relatives or friends, so we wanted to help them. They'd walk 10 to 20 kilometers to our place, carrying their clothes and salt. After the war, when I went to the city to study, these people welcomed me into their homes.

\section{The Passion of a Mother}

For families who had no friends or family in the countryside, and whose husbands or fathers had died during the war, simply surviving day to day became desperate. Suicides were common and thoughts of suicide were constant. Umon Takamatsu was born in Korea, where his father ran a fishing company before joining the Japanese Army. When he returned from the war he was sick and weak, and his family of four was forced to return to Japan.

We left Korea carrying only what we could carry on our backs. So we started from scratch in Japan. We didn't have a farm to grow rice or sweet potatoes, so we tried to exchange what possessions we had, like kimonos, for food. But my mother had only so many kimonos, and we quickly ran out. Soon after we returned, my father died, and then my 
grandfather died, followed by my grandmother. That left just the three of us, my mother, my younger brother and me. When the country began to recover, the government offered support to families like ours. But my mother was too proud. She said that even though the military fought the war, it was our job as civilians to support them with everything we had. And because of that, each one of us was responsible for the outcome of the war. She didn't believe it was right to live off of other people's money. No civilian knew just how the war started, but once it did, it was in our nature to defend ourselves at all costs.

At that time, you heard quite often about people jumping in front of trains. Because our household was in shambles, my mother thought this might be the best way out for us, as life had become just too difficult. One day, she took my brother and me to the tracks. I was five and my brother was three. Only at the last minute, she changed her mind. She took us to the tracks two more times, but, each time, she gave up the idea of killing us and decided to work harder to raise us to be good men without government support. She sold sweets on the street in Beppu during the day and taught sewing at night. Typically, she'd sleep two or three hours a night. She wore herself out and died at the age of 48 . In the end, my mother sacrificed her body and soul to raise her children to be the best possible citizens for the country.

\section{Suffering Together}

Over the first year of Occupation, food-rationing centers opened and people could go to the centers to receive small amounts. Bread, sugar, salt extracted from sea water, rice, and sweet potatoes were the staple foods. Beer was available, or rather a weak imitation of the real thing made from barley. People very rarely stole food. In fact, when asked about this more than six decades later, the question itself elicited surprise in the asking. "I can't remember any stealing, though there must have been some," says Yonosuke Yanase. "I can't imagine there was a lot. Even though people were suffering they wouldn't take from another person in the same boat. My memories of the time were of everyone sharing what they had with one another."

Medical care was in disarray, as equipment and medicine were in short supply. Midwife Tsuruko Tomonari recalls that, as soon as she heard the war was over, she and some other midwives, like most young women, escaped into the hills around Beppu. When they heard the Americans were not coming yet, they returned and continued delivering babies. 
Because we didn't have much food or medical supplies in the last year of the war, we lost many babies. Many of the mothers were weak and sick when they came to the clinic. If they had high blood pressure or weak kidneys due to their lack of nourishment, we had no medicine to save them. And many babies were born brain dead. This was a problem for more than a year after the war.

Nurse Nobuko Eto, the spirited girl who put out the fire in her hospital during the final months of the war, picked right up where she left off when the war ended.

In September, after returning home right after the war, I worked as a surgical nurse in the hospital that had burned during the bombing. It still pains me to remember the ex-soldiers with bayonet cuts stretching from the right shoulder down to the small of their back and the ex-navy men with wounds below their knees. They came to us wrapped in white bandages, and so we had to carefully peel off the bandages and disinfect them with hot water, repeating the process daily. We had no real disinfectant at that time. As military doctors came back from the war, they wore their navy or army uniforms to work and taught us how to treat the wounds. We were all trained in how to deal with limited supplies and medicine, something unimaginable to a later generation in Japan. Later I moved to the maternity ward, as the first baby boom hit in 1947. Over two years we delivered babies in old bomb shelters and makeshift facilities in homes. I remember it being fun, tough, and sad. In 1949, during his journey across Japan to apologize to the people for our sufferings, the emperor visited our hospital. 


\section{The Devil Comes Ashore}

\section{Getting Acquainted}

People kept a watchful eye out for the first American soldiers to arrive, and for the Occupation of their country to begin. The August 29 edition of Oita Godo Press, in a front-page article titled "Majority of Landing Forces Have to Stay in Tents This Fall to Repair Ports and Roads in Japan," reported that in spite of Japan's "full cooperation" with the Occupation forces up to that point, the Americans still anticipated possible interference, and cooperation was important. The article informed the residents that the immediate goal of the occupiers was to restore railway lines and begin a massive effort to repair roads so that heavy equipment could be transported for construction. The Americans, it said, would be importing "a great amount" of equipment from outside Japan. Most forces, it assured the populace, would be staying in temporary quarters outside the cities while long-term facilities were being constructed. Overall, they were told, the number of U.S. forces entering Japan would eventually rise to 500,000, and it would take over five months for them to finish disembarking. ${ }^{1}$

Even in the midst of planning for the coming Occupation, the people of Japan were reminded often of the great generosity and kindness of their emperor, whom many still acknowledged as a god. As it was still unclear how the emperor would be treated once the occupying forces arrived, perhaps this was an attempt by both his court administrators and the newly appointed government officials to show the best side possible of the monarch, emphasizing his willingness to cooperate with the former enemy and new master. Only two weeks after his announcement ending the war, for example, the August 30 newspaper in Oita carried a story described how the emperor would donate parts of his forests for the purpose of reconstructing Japan, with special attention to building 300,000 new homes toward this goal. Under the headline, "Venerable Emperor's Warm Consideration for Restoration: Lumber from His Own Forests to Be Donated," a spokesman for the government exhorted the populace "to show appreciation for the emperor's thoughtfulness," and "cooperate firmly with each other and increase the speed of reconstruction in every field." 
On September 3, the day after the surrender on the Missouri, the Oita newspaper headline read, "Plenipotentiary Shigemitsu and Umezu Sign Instrument of Surrender on U.S. Naval Ship." Why mention the names of the signatories in the headline? It seems that even though defeated and disgraced, these loyal followers of the emperor maintained high standing in their home prefecture. In the end, the article reminded people that even at its last official act to end the war, the emperor of Japan was represented by these sons of Oita. ${ }^{3}$

By mid-October, the first Americans arrived in Oita. The October 11 edition of the local newspaper, under the story tagline "Want to Get Acquainted: U.S. Officers Meet the Mayor of Beppu," the initial visit of Captains Baker and Swanson and two aides with Mayor Suematsu was reported. The purpose of the meeting, it said, "was not official, but casual, to become acquainted." In an act of courtesy, the newspaper reported, "They brought in all their food and supplies for their own use from the United States in order not to trouble the Japanese people." After these first Americans departed Beppu to inspect other areas of the prefecture, the Beppu City Chamber of Commerce met with local manufacturers and merchants to develop commemorative souvenirs "with full Japanese flavor" to sell to the officers and soldiers who were expected to arrive soon and live in their town for the foreseeable future. ${ }^{5}$ On October 13 , an advance team of seventeen Occupation soldiers arrived in Oita from the recently landed $28^{\text {th }}$ Marine Regiment assigned to Oita. The next day " 300 American soldiers under the command of Colonel Collins arrived by rail at Oita station. They were welcomed there by Governor Nakamura, Mayor Miyoshi of Oita, and other representatives of Oita City and Prefecture." The soldiers then assembled "neatly" at the station square and proceeded to their temporary living quarters, which had only weeks before served as the dormitory of the "Juvenile Airman's Academy." The officers had better quarters, staying 15 kilometers away in the hot springs resort Hotel Tsuruta in Beppu. ${ }^{6}$ These 300 troops were from Company A, $5^{\text {th }}$ Tank Battalion, $28^{\text {th }}$ Marine Regiment, which had first been stationed in the port city of Sasebo, until recently a large Japanese naval base. Soon some of these troops were sent over to occupy Beppu. 
After their arrival, on Sunday, October 14, the Americans were permitted to leave their dormitory and walk around Oita City and Beppu. Some went shopping for their families and some went to a Sunday church service. According to the local press, "Happy scenes were observed here and there." On that same day, Lieutenant Hashigami of the Kyushu Munitions Administration Office met five American officers in Beppu to begin inspection of military sites, especially stocks of hardware, in the Beppu area. The morning following this initial inspection, the Americans were taken on a tour of the Beppu hot springs and feted by local authorities. In the American major's response to this tour, he kept up the polite protocol with the following comments, as reported in a local news account, "The name of Beppu Hot Springs is so well known that I have longed to come here at the earliest opportunity. Everything is good at Beppu Hot Springs. I am totally satisfied with this and wish I could come again someday and enjoy a vacation here." That evening the Americans were treated to a performance of Japanese traditional dancing at Hotel Seifu, completing the evening by presenting chocolate, biscuits, and chewing gum to, as the local press reported, an appreciative troupe of dancers who "expressed their gratitude over and over, saying ,'thank you, thank you' in English."”

The next day they visited other cities with Lieutenant Hashigami to make similar inspections, review military sites, and dispatch reconnaissance parties to scout for good locations to establish new headquarters. They sought out local government leaders as they moved from city to city, making for a smooth transition to the American Occupation.

There were several immediate needs to address. Food was first and foremost. When the Americans first arrived they saw firsthand that the people of Oita needed food. But in those first few weeks feeding everyone was not their job. The people, at least for the foreseeable future, had to take care of themselves. Steven J. Fuchs, in his study of the Occupation period, sums up the conditions:

The resulting food shortage forced workers to migrate to the countryside in search of food, shelter, and employment. Factories struggled to maintain their labor force as food shortages led to the reduction or complete stoppage of supplementary rations for industrial workers, since the staple food ration received priority. Workers, having suffered from diminished rations for six years, displayed "mental lethargy and inability to carry out prolonged physical labor characteristic of chronic malnutrition." 
"Absenteeism" and "food holidays" prevailed as workers made "foraging expeditions to secure food." Food accounted for approximately 70 percent of a family's budget in 1946, as purchasing food on the black market and inflation devoured wages. ${ }^{8}$

Despite this lack of early attention to alleviating hunger, there were some attempts to help the people get on their feet, mostly through their own efforts with limited American support. Coming on the heels of positive early meetings, and seeing that worries about guerrilla or isolated military actions against the Occupation proved unfounded, the U.S. acknowledged the crises on October 14 when General MacArthur ordered the importation of foodstuffs and textiles, especially rice, wheat, and cotton. This was done, the local press reported, because of the severe food shortages that were "expected to continue even after completing the improvement plans, including cultivation of unplowed lands, land improvement, lake reclamation, and instruction in the cultivation of wheat to improve diets and enhance economic development." ${ }^{\text {9 }}$

\section{Working for the Americans}

At first the government tried to guide demobilized soldiers toward employment to address these needs. Local newspapers reported that, as of the middle of October 1945, former soldiers found jobs in agriculture, fishing, and manufacturing facilities. Towns and villages were encouraged to hire more of them, as many were still looking for work. As the number of American troops in these early days was small, Japanese laborers worked under American supervision to begin reconstruction tasks. Sanitation squads, for example, worked on housing facilities for the coming troops and others repaired roads that had been washed away by floods and heavy Japanese military use. Soon, this quick repair at least allowed the durable American military vehicles to move across the region. Railways were also repaired and former Japanese military equipment began to be inventoried. ${ }^{10}$ When the permanent Occupation headquarters in Beppu opened at the end of 1946,

8 Steven J. Fuchs, “Feeding the Japanese: Food Policy, Land Reform and Japan's Economic Recovery," in Democracy in Occupied Japan: The U.S. Occupation and Japanese Politics and Society, ed. Mark E. Caprio and Yoneyuki Sugiata (New York: Routledge, 2007), p. 27.

9 Oita Godo Press, October 14, 1945, p. 1.

10 Ibid., October 15, p. 2. 
demobilized soldiers and recently graduated high school students served as carpenters and laborers. Some were hired to work in the kitchen. Akira Tani, who was eighteen at the time, recalls:

I worked for two years at the American military camp, the first six months cleaning up and preparing the food. Then I was promoted to cook. I got this job because I cut the meat the way the Americans liked it. But they still didn't trust us completely. There were two of us Japanese cooks, but we were never on the same shift, so we never worked together. There would always be one American cook working with one Japanese, never two Japanese together. My salary was 13,400 yen per month. And I got three full meals free every day. The average pay for someone just graduating from high school then was about 3,500 yen a month. So my salary was huge and my friends all envied me and my family was happy.

As the Americans settled in, Japanese saw their food supplies slowly improve and jobs begin to appear. Crucially, they also saw that their women were not being systematically raped. Unexpected mutual trust between the Occupation soldiers and occupied Japanese, while still tense in many quarters, was off to a good start.

\section{Searching for Contraband}

But the war had only been over for a few months, and memories of that war and its barbarity remained fresh in the minds of the occupiers. In fact, there was still sporadic fighting in parts of China and Southeast Asia, so for some the war was not yet over. In addition, even though they entered Japan peacefully, the American troops followed the early Occupation admonitions to remain alert for possible, if isolated, acts of resistance, treachery, and sabotage. Accordingly, U.S. soldiers conducted surprise searches of schools, temples, shrines, and homes looking for unreported swords, guns, technical instruments, and documents. It was still too early to trust everyone, so actions were taken to root out possible hidden weapons and to instill a bit of intimidation in the hearts of those who might want to retaliate against the forces that defeated them.

Hideo Sonoda remembers the day the U.S. soldiers came to his home.

Shortly after the Americans arrived, they carried out door-to-door inspections in Oita. One day, two soldiers showed up at my home. They opened 
the cabinets and dressers to search for weapons or illegal publications. They came in the house quietly and performed their duties professionally, and of course they found nothing. But we were angry at them because they came in without taking off their shoes! I swear those two guys....

Very little contraband was discovered during these searches. In fact, most people had willingly given up anything listed as contraband, and soon the searches ended.

It was early in the Occupation, and over the next several months new American military units arrived to take control of the Occupation in Oita. But for the Japanese, it mattered little which units controlled their communities. Most of them were too preoccupied with finding food and clothing, and getting back to some sense of daily routine. ${ }^{11}$

\section{Confusion in the Classroom}

In the area of education, a mind-bending shift took place almost immediately. When the war ended, schools were not in session due to the summer holidays, which began in early August. But when the classrooms opened again in early October, every thing changed. Teachers who only weeks before had taught their students to prepare to die for the emperor discarded all texts referring to the war effort, or at least redacted those parts of the texts if still used in the classroom. The picture of the emperor disappeared, military training ceased immediately, sports returned to the playground, and the arts took on a radically new look.

Takafumi Yoshimura, fourteen, had been studying at temples and shrines in Usa for fear his school would be bombed. After the surrender he and his friends went back to their school to meet their teachers.

The thing I remember most is that we had no military drills now. Also, the contents of the education changed to cultural lessons, and we had no political or history class at that time. It was a transition period. For example, during the last months of the war, we were all poor and no one had nice clothes. The boys still wore military uniforms distributed by the school. That's all we had. But one day something happened that made me realize

11 Charles R. Smith, "Securing the Surrender: Marines in the Occupation of Japan: Kyushu Occupation," https://www.nps.gov/parkhistory/online_books/npswapa/extContent/usmc/ pcn-190-003143-0o/sec3.htm. 
that life had begun to change. Some Kagoshima High School students had been in Usa at the end of the war making cannons in the military factory. They were getting ready to return to their hometown. Before leaving, they came to our school to give a concert! As they walked into the school, we were all surprised that they wore their prewar school uniforms, and they looked very nice. That was the moment of realization. Also, soon after that, we put on a school play. During the war all plays had to do with winning the war, but this play was completely different. It was "The Emperor's New Clothes."

Times certainly had changed.

For some of the older students returning to school, a more focused interest in new politics took hold. Kou Takeda in Saiki was particularly interested in democracy.

When we got back in the classroom after working in the factories, the content of our education had already been revised. Teachers introduced new ideas about democracy and I was shocked by the speed of their drastic changes. Many in my generation were fascinated by the new politics, and I was especially interested in the creation of a new constitution. When the newspaper reported the drafts of the new constitution, I followed it closely. We learned that the draft was patterned after the American constitution, and I knew if Japan was to create its own constitution, it'd be like the disaster we'd had before. So I was enthusiastic about the new constitution and studied it carefully.

Another high school student remembers a political slant in his education, but not that of an American-style democracy. Shunsaku Nanri, who had grown up during most of the war in Shanghai as the son of a businessman, maintained a negative image of Americans.

I didn't like them because I'd been taught not to, and because Japan had lost the war. When I went to high school in Beppu after the war, I chose not to study English, but took German instead. While still a high school student, I got involved in the student movement against the American Occupation. Many of our teachers had become communists. The Japan Teachers Union was run by communists, and communist branches were set up in every school. Some students became communists. I attended the meetings, like most students, though I never joined the Communist Party. We were taught that Japan had been a bad country and that we had to change it. 
For most teachers, the quick changes became a terrible burden. They had been instructed to, indeed had taken pride in, teaching their wards about the godlike nature of the emperor and the absolute dedication all were expected to show the Japanese military and government. For some, the change was too much to bear. Nobuo Kawamura, the school teacher who recited the authorized spiritual history of Japan to his students each morning prior to being drafted into the army, returned to Oita to take up his old profession. But he could not face the new reality.

At the end of the war, and within days of leaving the army, I became so confused. So much had changed. For one year I stayed away from the school to recover from this psychological breakdown, because I couldn't stand teaching the new curriculum. I'd believed so strongly in the militarist education that I had taught my students, and now I must teach them democracy. However, there was a critical shortage of trained teachers, so I was eventually asked to take up my old profession again. When I returned to school in 1946, I found certain sections of the textbooks we'd used during the war were blacked out, especially any mention of the emperor. It was very difficult for me, but I began to recover, and soon became interested in some new ideas of socialism. So, I went from talking like a right-wing educator to a left-wing educator in one year.

Yet for a few, it was easy to shift to the new reality, though not always with the best of intentions. For some of these, the new democracy and breakdown of traditional values was used for their own advancement. In the town of Saiki, Minoru Kanda recalls:

During the war, one of the teachers in my school had reported to the authorities that my family couldn't be trusted. This was because my grandmother had kept some of the flyers dropped by American pilots toward the end of the war. Now, after the war, this same teacher came to our house to talk about democracy. But my grandma hated him and refused to speak to him. He was a man with a big, fake smile, an opportunist taking advantage of the hard times. His real reason for coming to see us was to get us to invest in his business, a shady scheme that we refused to join. We compared him to another teacher who struggled with the changes from a military to a democratic approach, and openly shared her concern with others. Everyone respected her for her honesty and hated the opportunist. 


\section{A Bitter Homecoming}

\section{Demobilized}

Japanese soldiers found themselves scattered around the Pacific, as well as in military installations throughout Japan. Those in Japan, such as Imperial Guard Isematsu Matsumoto, kamikaze support mechanic Mamoru Hirano, and former teacher and air defense soldier Nobuo Kawamura, were quickly demobilized and sent home. Others, like infantry trainee Tomiichi Murayama, who had just picked up and left on their own when the war was over, were required to return and formally process out of the military and into society. In their planning documents governing the Occupation, the Americans specifically dealt with this eventuality.

In order to effect the collection and documentation of personnel who have discharged themselves or been discharged without authority [occupying forces require] all such personnel to report by a certain date to selected centers to be specified by Army Area Headquarters or by Depot Area Headquarters.... It is provided that those reporting will not be subject to disciplinary action for desertion or other stated irregularities, but failure to comply with the order will entail severe penalties. ${ }^{1}$

Following the emperor's declaration ending the war, the homecoming for some of Japan's fighting men was delayed for months, even years. This proved the case for Oita $47^{\text {th }}$ Regiment captain Shunichi Make, $47^{\text {th }}$ infantry soldier Naomasa Kodama, and young naval telegraph operator Jiro Nakano. When finally reaching Japanese soil aboard transport ships, they were met by Occupation forces to complete the demobilization process. As spelled out in the "Administrative Provisions for Discharge" found in American plans to secure the Occupation, the returning soldiers were placed into skill categories to determine how quickly they would be returned to their homes. The report stipulated:

Certain priority categories of personnel are first discharged. These categories may include:

a Personnel for work in certain public utility services.

b Personnel for work in transportation services. 
c Agricultural workers.

d Personnel for work in certain classes of building trades.

e Such other specialist personnel as may be required by army area commanders. $^{2}$

Demobilization began after skills were assessed, with the Occupation forces spelling out in detail what each person was entitled to as they headed home. This included payment due each soldier or civilian employee of the military up to the date of discharge, plus a half month thereafter. It also included "haversack rations for the journey from the place of discharge to the place of residence, as well as food and clothing rations cards." Additionally, "each man, on discharge, is issued a travel warrant to his place of residence." Finally, each man could keep select military-issued goods, though there were exceptions. Under the category of clothing, the following order appeared:

a Each individual is allotted to retain, without payment, after discharge, the following items of clothing:

1 Field Cap

1 Field Jacket

1 Pair Long Cloth Trousers

1 Belt and Buckle

1 Pair Boots or Shoes

1 Pair Braces (if desired)

1 Greatcoat

2 Shirts

2 Pair Underpants

2 Pair Socks

2 Handkerchiefs

b In additional to the above, one blanket per man may be issued.

c Deficiencies of clothing in relation to the scale in a and b above may be made up from local stores, if any are available.

d All insignia and badges of rank are removed from clothing retained, prior to departure of the individual. ${ }^{3}$ 
Upon departure for home, each former soldier received the following instructions in writing:

1 You have received the last payment which will be made by JAPANESE armed forces authorities for service with JAPANESE armed forces organizations. Pay has been calculated up to and including the day of discharge and for half a month thereafter.

2 On arrival at your destination, you will report, with your Discharge Certificate, to the local police station. There you will receive:

I A civil Identity Card.

II Instructions on registration at the local employment office.

III Failure to report at your local police station will result in investigation and punishment.

3 You will not be registered for employment nor will you receive food and clothing rations cards except on production of your discharge certificate. $^{4}$

\section{Awkward Reunions}

Families in villages and towns around the prefecture waited for their sons, brothers, husbands, and fathers to come home. In many cases, the wait was long, and in some cases forever. "When the war ended, people in our village wondered when the men would come back, or if they would not be coming back. There were quite a few people from our village who had gone to fight, so we were waiting for them. Some died, and some were missing," recalls Hidekatsu Nakano. In some cases families were in for a lifelong wait, as no record of death was forthcoming and the expected loved one never came home. In other cases, the wait was long, but eventually rewarded. Akira Tani, a student in middle school when the war ended, remembers his brother's return.

My third brother had been working in a factory in Manchuria, and then was conscripted into the army. After the war, but unknown to us at the time, he ran away from the army to avoid being captured. He moved from one place to another in China but eventually boarded a ship back to Japan. We didn't know anything about this. One day he just appeared at our door step. He walked in and said, "I'm home." My father was the 
first to see him and called to everyone to come. He said to my brother, "Fumioka, we thought you'd died in the war!"

One day, Sadayoshi Yutani's mother told him and his sister that his father was coming home from Thailand. Seven-year-old Sadayoshi went with his mother and sister and grandparents to Oita station to meet his father. "It was the first time in my life that I saw my father in person. My sister said to him 'welcome home.' I was shy, stayed with my mother and said nothing to him. He came home with malaria."

Children who had been expecting only months before that they would become soldiers and die for their country saw the former soldiers walking the streets still wearing their ragged, once proud uniforms. They also watched them beg, sometimes from their former enemy. "The Japanese soldiers hated the American soldiers, but didn't express their feelings directly. In fact, many of them wanted cigarettes from the Americans, and took them when they could. This was a very sad scene to watch." ${ }^{5}$

The general sentiment was mixed and muted, but most people still admired these defeated men for the sacrifices they had endured. Ichiro Hashimoto, fifteen years old when the war ended, remembers seeing the men come home. He felt a sense of appreciation and, at the same time, sadness.

When I saw the soldiers return, my first thought was, "Gokurou sama deshita," a common Japanese phrase depicting a pat on the back to show respect and gratitude for having worked so hard. My family lived right by the station in Oita City, so some of the returning men would stay at our house for a night because ours was the only house around. They hadn't eaten well for a long time, so we fed them. They came from Manchuria and had fought in China.

Not everyone was welcomed so warmly, for the war's loss was still raw and there was little energy or inclination to give a grand welcome home. "They came home quietly," remembers Toru Takaya, a high school student at the time. "Some of the soldiers told me that when they left to join the war, everyone cheered and sent them off, but when they came back there was nothing. People looked at them coldly." Tetsuo Tsukuda saw the men return to a hard life.

When they came home, there was no organized welcoming event; they just came home one by one to their families. Many had psychological 
problems and stayed away from people for long periods of time. Their friends had been killed, but they came home alive. This was shameful for them, so they stayed silently at home. Those who got out of the house had a difficult time finding a job, though many kept looking. Some became carpenters, and a few became teachers. But even these men did not talk about the war, and kept silent for 10, 20, even 30 years.

Psychological breakdown was common among returning soldiers. As seen earlier, Nobuo Kawamura, even though he had never fought overseas, refused to return to his job as teacher for over a year while he secluded himself at home. Naomasa Kodama experienced the same mental anguish; after returning from Indonesia he refused to leave his house for six months. It was a time of hunger in Usuki, his hometown, but he could not face leaving the house to find work. Even at 95 years of age, the shame of defeat and loss runs deep inside him. When asked to sit for a photo with his military medals and the battle flag carried by his brother during the war, he refused, saying "I cannot have such a photo taken holding those wartime keepsakes, because Japan lost the war."

Even the women who had served in the army, in most cases nurses, also initially withdrew from society and refused to leave their homes. Yukie Matsumoto, the army nurse who walked back to Oita from Kagoshima at the end of the war, remembers:

When I got home I didn't want to do much of anything other than be a good daughter and help my family with household chores. This lasted about a year. Then one day, I had to take my older sister to Beppu where she was hospitalized in Kokuritsu Memorial Hospital. When I got to the hospital, I saw that one of her nurses was my former army nurse instructor. She asked what I was doing with my life and I told her. She said it was such a waste that I wasn't making good use of my skills as a nurse, so I started working with her and stayed there for some time. When the American doctors came to inspect our work, they criticized our standards as being too low. Even though l'd graduated during the war from nursing school, I had to take training courses and then retake the licensing exam. I took it and passed, and in 1951 I became fully certified and worked as a nurse for many years.

A few of the men had climbed to high rank in the military, and for them the return had its own problems. Takeyoshi Kajiwara tells of his uncle, who led troops in Papua New Guinea, only to be one of the few to survive 
the fighting and hunger there. He returned home two years after the war ended. "When he finally came home, he was all bones, no fat. And even though he was very smart and a graduate of a military school with many managerial skills, he couldn't find a job. At that time, former high-ranking officers like him couldn't get employment in the government or jobs that needed security clearances. So he went into farming. Only years later did he become a school teacher, teaching Japanese."

But some men were able to take up where they left off. Tomiichi Murayama went home to visit his family and then quickly returned to Tokyo to continue his studies at Meiji University. He returned to Oita City after graduation, where he entered politics as a young activist in the Socialist Party, eventually holding the position of prime minister of Japan.

Former imperial guard Isematsu Matsumoto returned to the small hamlet of Ooga near Hiji, where he worked on the family farm all his life. And Mamoru Hirano, after demobilization, returned to Usa where he opened a factory making shochu, a locally produced spirit.

Some stories took uneven twists and turns. Jiro Nakano, the young boy who joined the navy as a sixteen year old, returned from Indonesia to Beppu, where he became, in his own words, "a juvenile delinquent. I walked around the streets, getting in trouble, sometimes cursing the American soldiers. I was a very angry young man." Later, he worked in the American camp in Beppu as a handy man, but he never grew close to any of the Americans during that time. After the camp closed and the economy eventually started to recover, he worked with his family in real estate acquisition.

Finally, there is Captain Yunokawa, the former naval kamikaze officer who, at the instruction of his commanding officers, ignored the surrender command, went underground and quietly disappeared into a small town with a new identity, waiting for new orders to protect the emperor's family.

From the recluse to the rabble rouser, the university student to the family businessman, and the farmer to the underground nationalist, these soldiers of a defeated military discovered a country unsure how to welcome them home and uncertain how to integrate them back into a now changed society. What they all had to deal with, no matter their mental or financial state, was the presence of their former enemy in their streets, their shops, their hospitals, their schools, their homes, and their brothels. After the first few hundred occupying soldiers arrived in Oita Prefecture in the weeks after the surrender, the trickle turned into a flood, and the cities of Oita, Usa, and especially Beppu, were full of Americans for several years, changing the prefecture, like much of Japan, forever. This American presence would last from the formal Occupation period through the end of the Korean War. 


\section{The Occupation Takes Hold}

\section{Censorship and a New Order}

As the Americans moved into Oita Prefecture, censorship of the media continued apace. The only change, according to journalists Shunsaku Nanri and Yasuo Tanaka, was merely a transfer of censorship from one military power to another. During the war the Japanese Army censors reviewed the newspapers each day to approve copy. The Americans did the same. Postwar censorship covered not only newspapers, but also magazines and books, some of which never saw the light of day. After the war, journalists found certain stories off limits, especially those covering questionable activities of American military personnel.

The Japanese "never knew if the Americans committed any crimes or had any misconduct, because they were the occupiers, and negative stuff about them was not reported." Journalist Tanaka recalls that he played it safe and "never wrote anything about the lives of the Occupation forces." Reporter Nanri, on the other hand, found a way around this restriction. "We couldn't write about the American soldiers directly, so if I found out one of them did something illegal, or bad in any way, I wrote about a 'tall man.' Everyone could guess who this was. If they did something good, however, we could write about that. Other than that I wasn't censored much."

The local press, under American control, instructed citizens on Occupation policies and occasionally inserted articles highlighting the ceremonial activities citizens were expected to attend. Two articles from the Oita Godo Press, both from June 1946, reflect such stories. The first, from June 16, dealt with Japanese ownership of American goods.

The residents of Oita Prefecture are requested to comply with the following orders issued by Oita District Occupation Headquarters, on October 15: All Japanese shall be prohibited from owning any goods formerly possessed by the U.S. Occupation Army. Those who own such goods shall bring them to the nearest police station by the end of this month. Those who adhere to the orders shall not be punished. Failure to comply shall result in serious consequences. Additionally, Japanese must not sell food 
and drinks to the Occupation Army personnel. All residents of Oita Prefecture should respect these orders. ${ }^{2}$

The cause for this admonition was not just a concern that citizens were stealing American goods. It was aimed at Japanese who dealt in a newly flourishing black market encouraged by some American troops. Toyoji Koya, a former police officer in Beppu assigned to enforce this order, explains the problem.

For example, the soldiers of the Occupation forces sold blankets, food, and clothing on the black market. Due to a severe shortage of adequate clothing, buyers used the U.S. military blankets to make pants to wear. However, even if the blankets were dipped into different colors of dye, you couldn't hide what they were. Cigarettes and soap were also at a premium and found eager buyers. The soldiers also sold medical supplies on the black market, items such as bandages, penicillin, and gauze. During the Korean War, the American soldiers brought guns back from the war and sold them to local criminal gangs, and crime increased enormously after the war. We had to deal with these problems and were on constant alert. When we caught American G.I.s engaging in these illegal actives, we'd question them, hand them over to the Occupation forces, and the American officers took care of it. The soldiers did anything for money. ${ }^{3}$

An article from June 30 under the headline "Violence against Occupation Army Shall Result in Severe Punishment" reads, "On June 29, Oita and Miyazaki District U.S. Occupation Headquarters issued a warning to all Japanese, stating that those who act with any form of violence against U.S. Army soldiers will be severely punished. At the same time, U.S. authorities will properly punish U.S. Army personnel who act violently."

There were the occasional thefts of watches, cameras, and money from the soldiers, as well as fights between Americans and locals. In some cases when the soldier was the instigator, he might be arrested by the military police, but never had to face justice in a Japanese court. In one case documented in a letter from camp headquarters, a sentry on duty at the military camp shot at a local citizen whom he thought was acting suspiciously in front of the camp. The investigation into this matter determined that the sentry had broken

2 Oita Godo Press, October 15, 1945, pp. 1-2.

3 Tadao Saga, Beppu and the Occupation Forces (別府と占領軍) (Beppu, 1981), pp. 202-208.

4 Oita Godo Press, June 15, 1946, p. 2, and June 3o, p. 2. 
camp regulations and would be reprimanded. The following contains part of a letter written to Beppu authorities from the camp commander to a local official and shows not only the commitment to address the incident, but also the need to maintain good relations with the community:

I desire to express my regret to Mr. Okamoto and to the people of Beppu for this unfortunate incident. Appropriate action is being taken with the sentry involved. I am taking steps to prevent future unpleasant incidents such as this by insuring that my sentries will not discharge or fire their weapons from locations outside the boundaries of the camp, and also they will walk their post within the boundaries of the camp. In addition, flood lights will be installed at the place of the incident so as to allow the Japanese people to utilize this road without fear. ${ }^{5}$

This need to foster trusting relations with the community went beyond polite letters and correct protocol in communication. It also invited the populace to participate in American holidays and festivities. One of the first such occasions was during the 1946 celebration of American independence. The news story bears the headline, "Celebration March in Beppu: For the Brilliant War Record of Oita and Miyazaki District Occupation Army," a lead that surely had no trouble passing the censor. It reads:

The Oita and Miyazaki District U.S. Occupation Army will organize a Military Celebration March on America's Independence Day. The Headquarters' declaration states that on July 4, the $19^{\text {th }}$ Regiment of the U.S. infantry will march into Beppu City to celebrate the $170^{\text {th }}$ U.S. Independence Day. It is quite significant for us to recognize this regiment with a lengthy history and brilliant war records as one of the Occupation forces. The celebration march will start from Higashi-Beppu station at 11:00 a.m. and go through the autoway on Kaigan Street, then turn left at Ekimae Street, proceeding to Beppu station. There they will hear speeches from their commanders. Colonel Charles P. Lynch, commander of the regiment, encourages Beppu and Oita citizens to observe the celebration. ${ }^{6}$

This parade marked a turning point in the Occupation of Oita, as the $19^{\text {th }}$ Infantry Regiment had arrived in Oita City in May, relieving the $6^{\text {th }}$ Marine Regiment of responsibility for that area. The $19^{\text {th }}$ would eventually 
move from temporary quarters in Oita into what its regimental historian described in 1949 as "a beautiful new and modern post located in Beppu. This post was appropriately named 'Camp Chickamauga' and is now the home of the 19th Infantry Regiment."

The official move occurred in December 1946. This regiment would stay in Beppu for much of the Occupation, which ended on April 28,1952. They would be followed over the next several years by other units to close out the Occupation, and then as a training base for the Korean conflict. For the citizens of Oita Prefecture, especially those in Beppu, the names and insignias of the Occupation units blended together, as their presence served as one continuous, seamless period while they tried to get their country back on its feet.

\section{Baseball and Chocolate}

Memories of the children during that period reflect a fascination with the American soldiers. Yoshio Ninomiya, a young teenager in Usa at the time, remembers them as "very handsome. I remember they had long legs and would give us snacks. They were very kind.” Takafumi Yoshimura, also from Usa, watched but never talked to the Americans. He thought they were nice, but on one occasion he and his friends had to reconsider this, if only briefly. Their concern was for one of the young women in Usa. "There was a bride on the street when an American jeep drove up and the soldier went to talk to her. He then put her in the jeep and drove away. Of course we worried what would happen to her. But later we found out that this American was just fascinated by how the bride was dressed in her formal kimono and how she looked, because he had never seen a Japanese bride before. Then, after 20 minutes, he brought her back with lots of wedding gifts."

Hidekatsu Nakano remembers the first time he saw the Americans. "These guys were very big, very different from us, and I was really curious about them. Some of them stayed on the second floor of a traditional Japanese inn, and when they came to the windows they'd tossed chocolates to us. I never harbored any anger toward them, even though we lost the war."

Stories like this dominate the memories of those who were children during the Occupation. Toyoki Goto, who was fourteen at the time, remembers

7 The $19^{\text {th }}$ Infantry Regiment, 1861-1949, published on September 20, 1949, at Camp Chickamauga, Beppu, Kyushu, Japan. The name of the camp comes from the Battle of Chickamauga, which took place during the American Civil War and in which the $19^{\text {th }}$ Infantry Division participated and distinguished itself. 
that "when the Americans came in their jeeps and started giving us gum, that's when it really sunk in that we had lost the war. Seeing them for the first time on our land was when it hit me." Eiji Ono, only six years old at the time, still has vivid memories of the American ships docking in Beppu Bay and of watching the soldiers march up Nagarekawa street to the newly constructed Camp Chickamauga.

I was a kid, so I wasn't particularly scared. They were different colors, with lots of black soldiers, and this really surprised me. My parents never told me to stay away from them, as they were friendly, always giving us chocolate and playing with us. But we were scared of the MPs. They walked around with guns and controlled the soldiers. Sometimes they even shot their own men, I was told. When the soldiers got drunk and went crazy, the MPs would take care of the situation.

When it was clear that the streets would be safe and that the American soldiers could be trusted, some playful interaction began. There was also a fixation on learning a few words of English. Tetsuo Tsukuda recalls the day he tried to use his newfound English on the soldiers. "One day, some soldiers stopped their jeep to speak to me. I was very nervous and had no idea what they said. I could think of only one sentence, so I said, 'OK, please go straight on, cross the bridge and you will see another bridge. That's it.' They said OK and went off, but that was a sentence I memorized from my textbook, and I didn't really know what it meant. So I ran away as fast as I could. That was my first English conversation."

Picking up English took place in several locations, as did different ways of taking advantage of American wastefulness. Tadashi Ono, for example, was happy when baseball returned to the sports ground for multiple reasons. "Once I was playing baseball near the American base in Beppu and the soldiers were also there but didn't have enough players for their game, so they invited me to play with them. I had already memorized, 'Please give me some chocolate and chewing gum.' Now I learned 'Come on,' which they said all the time during the game. It was after the games that we had an extra treat. The American soldiers would leave the butts of their cigarettes on the field after playing, so we picked them up and smoked them. That's how I started smoking, and I haven't stopped since."

Baseball played a key role in establishing communication between the Americans and Japanese youth. In the town of Saiki, Kou Takeda had such an experience. 
Less than a month after the war was over, a group of American soldiers came to our school on a friendship visit. It was the first time I saw Americans. They started to play baseball on our sports field at the school, and it was the first time I saw a new type of baseball glove. They used their equipment to flatten the ground, so we could play better. A month later, we had a friendship game between the students and the soldiers, and I remember thinking, "Why did we have a war with these people?" The American troops were nice. Compared with Japanese soldiers, who were arrogant and looked down on people, the Americans were friendly and relaxed.

Aside from the gum and chocolates, the most memorable image of Americans for the children was the jeep. They were everywhere, and most of the children were taken with them. Kou Takeda recalled a friend of his "was so enamored of the jeep that he begged for a chance to ride in it. After that, he said he would one day buy his own, which he did decades after the war was over.

Sadayoshi Yutani, the young boy shot at by a Grumman while fishing, returned from the countryside to Oita City after the war ended. He remembers seeing American soldiers early on:

My mother used to take me to the hot springs in Beppu. I kept looking at the Americans because they looked very different from the Japanese. My mother warned me not to stare at them, because if I did, they'd eat me. But of course, people soon relaxed around the Americans. After I started going to school, there was a camp between my home and school. I'd passed the camp every day. The American soldiers treated us nicely and offered us chewing gum. My friends and I were curious about the American families, so we'd climb the fence to look into the officers' homes. We were really envious of their children. They dressed very well, and we were blown away by how many toys they had to play with. Sometimes the Americans used the old air fields to practice parachute jumping, and after they landed we'd run out to help them gather up the parachute. Then they'd give us more chewing gum.

\section{The Americans Were So Wasteful}

Some of the children who lived close to live fire combat training centers have strong impressions of those days, and describe the differences they 
observed between the Japanese and American soldiers. Takeyoshi Kajiwara, a primary school student at the end of the war, says:

The American soldiers stationed in Beppu would practice at the firing range next to my house. I always went there to watch and talk to the soldiers. Well, not really talk, just make gestures. When they practiced rifle shooting, they'd get the bullets out of an ammo box. I wanted one of those cases because it was big, made of metal and very sturdy. In my family, we raised ducks and chickens, and we could use it as water feed. Also, the ammo box and bullet cartridges were quite precious for us because we could make money by selling the metal shells to rubbish shops. The Americans were so wasteful. After each practice, they just left the empty boxes and cartridges behind without cleaning them up. Once I grabbed one of the ammo boxes and ran away with it to use for my ducks. Sometimes I'd take eggs to the soldiers. That made them happy and they'd give me chocolate and chewing gum. My father was happy, too, because he enjoyed chewing gum as much as I did.

Hideo Sonoda grew up adjacent to the firing range of the Oita $47^{\text {th }}$ Regiment, which converted to an American base after the war. The difference between the Japanese and American soldier left a strong impression on him:

The American soldiers were very different from Japanese soldiers. The Japanese soldiers were serious and disciplined. The Americans were more casual and laid back. The Japanese would take very careful aim at the target and fire one shot. The Americans would see the target and open fire in rapid bursts with their machine guns. When the Japanese practiced shooting, they'd count the empty shells to the number of targets hit. The ratio had to be one to one. That was how serious Japanese were in taking care of their possessions. But the Americans would shoot randomly and not care about the number of shells. Also, while the shooting was going on, the Japanese soldiers would stand at attention, perfectly straight guarding the roads. The Americans, on the other hand, just slouched around chewing gum.

While the acceptance of the American soldiers as friendly occupiers was shared by many, not everyone was so enamored. Even in the same family, attitudes varied. Takeyoshi Kajiwara comments, "My mother's younger brother was killed by the Americans when he was aboard an oil tanker headed for Okinawa. We don't hold grudge against the Americans for that. 
But my father-in-law was different. He'd been a professional soldier and never forgave the Americans for defeating Japan. After the war he said that the U.S. was a dangerous enemy and could not be trusted. He would never use American English and even to this day, at 94 years old, he won't use terms such as Occupation, chewing gum, ice cream, and so on. Japanese militarism had grown deep roots in his head."

Even some children resented the Americans. Yonosuke Yanase and Umon Takamatsu were two of these. Mr. Yanase remembers:

My family lived in Beppu, and I could speak some English. Occasionally I'd be called on to serve as an interpreter for the Occupation soldiers. But I didn't care much for them, so I tried to avoid them as much as I could. I never asked for or received anything from them. I didn't want their handouts, and this was my way of practicing the way of Bushido. I broke this principle once, however, when I took a cigarette from one of the soldiers. "Kool" it was, really good and I got addicted to it. But I used to hate the Americans because we lost.

Umon Takamatsu, following the spirit of discipline taught to him by her mother, recalls:

Some Americans liked to play with kids and offer them gum and chocolates. And kids would chase after them, begging for these things. I never did and would never do that because I felt strongly "Why are we supposed to receive this?" I didn't want anything from an enemy. Thinking from the Bushido perspective, there is a phrase that says the samurai should never take anything from someone else, even if he is suffering and starving. That's how I was raised by my mother. I didn't think it was a good thing that these other kids learned the idea that they could get things so easily. After all, it wasn't like an organized volunteer effort to distribute food; they just enjoyed throwing the candies on the ground and watching the kids scramble to pick them up. 


\section{Miss Beppu, Crazy Mary, and William Westmorland}

\section{The Call for Volunteers}

As the American force grew and Camp Chickamauga in Beppu settled in as the regional Occupation headquarters, the thousands of men assigned to Oita began looking for entertainment outlets. Some Japanese have speculated that Beppu was spared any bombing because it was already designated to be the base of operations for this region. The reasons for this are twofold. First, Beppu had no strategic factories or military bases, thus there was no need to destroy it. This simplified setting up a base, as no reconstruction of the city had to be undertaken from the beginning. Second, Beppu was known as a holiday destination renowned for its hot springs and entertainment, or pleasure, district. Within the entertainment district were restaurants, bars, and brothels. The army knew that it would need all of these to keep the troops relaxed and comfortable. The streets of Beppu soon became crowded with young women flocking to the town. For some time all of this was strictly legal, as on August 18, 1945, the Interior Ministry, working under the guidance of the Occupation Headquarters in Tokyo, authorized the opening of special brothels for American soldiers. This was something encouraged by the Japanese for fear that without this outlet, their women would be raped by the Americans, not only shaming the women and their families, but threatening the "pure blood line of the Japanese people." This concept was called the Yamato nadeshiko, or "personification of an idealized Japanese woman." A radio message was sent to prefectural governors and city officials, as well as police chiefs throughout Japan instructing them to open and supervise these "comfort stations." They then issued a call to collect as many women as possible for the operation. In other words, it was a patriotic duty of the city leaders to open the houses and for the women to volunteer themselves for this service. A fund of 100 million yen was established under the Recreation Amusement Association (RAA) to fund these enterprises and on August 28 a sign appeared on the streets with the following message:

For all Japanese women! Please cooperate by becoming comfort women for the American troops as part of the national urgency to heal the wounds of the war. We need female workers between the ages of 18 and 25. Free accommodations, clothes, and food will be provided. 
It did not take long for the troops in Oita and surrounding towns to begin taking advantage of this service. As soon as the first troops arrived in October 1945, women appeared on the streets. These early prostitutes were destitute, unregistered, and dressed in wartime work pants and clogs. Some sold themselves merely for a bowl of noodles. By early 1946, the brothels started to appear, mostly along Beppu's Nagarekawa Street, which was a straight shot up a slight hill from the port of Beppu heading toward Camp Chickamauga. Two types of prostitutes competed for business now, those who worked in the legal establishments and those growing numbers who worked the bars and streets. The street girls were labeled "Pan-Pan girls," and over the years even the women in the brothels gained this working title. The derivation of the name "Pan-Pan" has competing explanations. One holds that when the soldiers called for service from the ladies, they clapped their hands for attention, making the sound "pan-pan." Another explanation was that in the early days, Japanese women were so desperate they would exchange their bodies for two loafs of pan, the word for bread in Japanese, thus "pan-pan."

The houses sprang up quickly. When the business was in full force, there were over 100 legal brothels in operation, with between 800 and 1,00o PanPan girls working throughout the city of Beppu. The total population of Beppu at that time, outside the military presence, was close to 100,000 people, so their presence was known to all. Like most of Japan, food and clothing in the Oita area were at a premium. Therefore, applicants for employment in the houses were not hard to come by. The brothels, called kashiseki (rental rooms) by the local populace, were usually named after the owner, such as "Nagata House," "Inoue House" and, taking on an American flavor, "George House." As the number of troops increased and the money flowed, the days of the early prostitutes selling themselves for noodles transitioned into brightly painted women vying for customers.

The kashiseki were divided into different territories, and clearly demarcated between those for white soldiers (hokobu kashiseki) and those for black soldiers (hamawaki kashiseki). American racism was alive and well, even in Beppu. It was noted by the local populace that the white soldiers and black soldiers never crossed over into the others' territory. In additional, while these houses were available to all Americans, they were frequented mostly by enlisted men up to the rank of master sergeant. Most commissioned officers did not use the houses, but spent their time in clubs or cabarets with hostesses and dancers, most of whom were in fact just higher priced Pan-Pan girls. ${ }^{2}$ 
The response of the local citizenry to the growing presence of the Pan-Pan girls was mixed. The girls on the street were impossible to miss, even for the children. This memory comes from a boy who was a primary school student during the Occupation.

I remember seeing lots of street girls, the Pan-Pan girls. They were young and looked very rich in their colorful dresses and makeup. When the Americans finally left Beppu, the train station was filled with Pan-Pan girls saying goodbye and crying. The Japanese never kiss in public, but there were lots of soldiers kissing lots of those girls. ${ }^{3}$

Their presence proved so ubiquitous that some schoolchildren wrote a letter to the police commissioner about what they saw in the streets. It is not clear if this was a voluntary action, or encouraged by adults. In any case, the children pleaded, "Please hear us out. We feel the way the women present themselves is bad, and it makes us feel ashamed. We think what they are doing is the same as dogs and cats. Please help them." ${ }^{\prime 4}$

While most people recall the Pan-Pan girls with a distinct sense of regret, there remains a lingering acceptance and absence of harsh judgment toward them when recalling those years. "Many of the girls working in Beppu came from the island of Shikoku and places outside Beppu. The girls from Beppu who did this went to other places, like Fukuoka," remembers Tokie Ono, who saw the girls every day as she sold fruit from her family's shop on Beppu's main street. "For me, this was just their job. It was a hard time, and they made money to send to their parents."

Another woman echoes Mrs. Ono's words, saying:

We didn't like it, but I can't be critical of them. In Japan, it's always been a woman's job to put food on the table. If the man of a family has a job and brings money home, all is well. But if he doesn't have a job, the woman still has to put food on the table. At that time, job opportunities were limited for women. The Pan-Pan girls had to do what they could to provide for their families when their fathers, husbands, and brother were either dead in the war or couldn't find jobs. To me, this was just their job. It was a hard time, and they had to make money to support their families or send to their parents. ${ }^{5}$ 
The reflective view of many men proves generally more harsh, but also mixed. Even some acknowledged that the presence of the girls in Beppu made contributions to the economy and, at a minimum, kept the soldiers away from other Japanese women. In fact, some acknowledge, nothing much changed except the vast number of girls, as prostitution had been legal in Japan well before the Occupation. Umon Takamatsu, whose mother taught him to withstand pain and suffering without handouts, says, "During the Occupation there were lots of problems in Beppu with prostitution. I can understand that the girls had to do this to make a living, but.... Well, it changed Beppu."

On a school trip to Beppu from Saiki one day, Minoru Kanda had his first view of Americans. They were strolling in the street with the Pan-Pan girls, he recalls, which gave him a "bad impression" that he still holds today. But he also acknowledges that the red light district made Beppu an active and prosperous town while other places suffered. "In the daytime, there were 100,000 people in the town, but at night it seemed to grow to 200,000 ! The prosperity ended after the Korean War, when the soldiers left." Toyoki Goto agrees, saying, "It was a job, their line of work." Another grudgingly accepts the activities of the Pan-Pan girls from his fear of what American soldiers would do to Japanese women if they had no access to the prostitutes. "In Beppu it wasn't like the Americans were raping the women, and besides, Beppu had girls like this even before and during the war." The same rationale was used in the town of Usa, which held a small contingency of Americans as they dismantled the Usa Naval Air Base. "There were about 85 American soldiers in Usa. Some of the women in a restricted area, called the pleasure quarter, got along very well with them. This place was first set up by the Japanese naval forces when they stationed here, and now they just switched their clientele to the Americans." ${ }^{6}$

\section{Closing the Houses - Sort Of}

The presence of the brothels and Pan-Pan girls, while initially serving both Japanese concerns for maintaining the purity of their culture and American soldiers' sexual gratification, was not without serious consequences that brought occasional policy shifts. The most serious problem concerned the quick spread of sexually transmitted diseases (STDs). One spot check found that $90 \%$ of the RAA prostitutes had contacted at least one type of

6 Interviews Interview with Nobuko Takahashi, Takafumi Yoshimura, Minoru Kanda, and Toyoki Goto. 
STD. American officials were shocked to discover that these diseases ran rampant among the soldiers. In one division, $70 \%$ had an STD. The cause is not surprising, according to a Beppu brothel owner at the time, when one discovers that each girl serviced between ten and eighteen soldiers a day. This brought a closure to the RAA facilities in 1946 and threw the business into a tailspin. The American military made all these facilities off limits, visiting the owners and telling them the system was over.

A former brothel owner in Beppu recounts what happened next:

The military authorities put out an order that our places were "offlimits" now. The women were worried, "What will become of us if the soldiers stop coming?" We all attended a protest meeting at City Hall organized by the association of brothel owners and called by our Union President Nagata and Association President Nishida. We discussed the life and death nature of this decision for our livelihood, but we left feeling that the situation would not get better. ${ }^{7}$

This particular owner was visited by an American officer at his establishment and told to close it down, but he did not want to give the women the bad news. The following day, when the officer called to check if the women had been brought together to hear the news, the answer was no. That evening, the officer returned to the house and spoke to about 50 to 60 prostitutes, informing them that it was not good for women to do this work, the business was shutting down, and they had to leave. Some of the women tried to quit and looked for other jobs; however, change proved difficult. Most had no training or skills that prepared them to work, for example, as office ladies. So they went back to work as Pan-Pan girls. ${ }^{8}$

Over the years of Occupation and into the Korean War, Beppu witnessed several attempts to close the businesses. These included everything from raids by Military Police to civilian enforcement of Japanese antiprostitution laws. But the customers kept coming, and the Pan-Pan girls and their bosses continued to service them.

The American military authorities periodically disseminated regulations to curb behavior detrimental to army discipline, including visits to the local brothels and other nightspots frequented by the soldiers. It speaks to not only the spread of STDs, but also black market activities practiced throughout the Occupation and Korean War deployment in Beppu. The 
following policy circulated around town in October 1954, when the Pan-Pan houses were illegal but still active. It stipulates:

In response to many questions which were asked concerning the placing of certain bars in Beppu "Off Limits," the following is a statement of policy. A commanding officer is responsible for the health and welfare of his men as well as for the training and combat readiness. Since he has this great responsibility, he is also given great authority. He can, in the interest of the welfare of his men, dictate where they may go and what they may do, even during their off duty hours. This right or duty is established not only by army regulations, but also by army custom.

Concerning bars, cabarets, tea houses, cafes, restaurants and similar business establishments, the following acts or omissions are felt to be undesirable for health, welfare and discipline of this command.

1 Failure to maintain proper sanitary conditions.

2 Failure to maintain proper venereal disease control measures.

3 Selling or buying black market merchandise, such as cigarettes and whisky on which Japanese or United States of America tax has not been paid.

4 Selling or buying narcotics or other harmful drugs.

5 Selling alcoholic beverages to intoxicated individuals.

6 Selling alcoholic beverages to soldiers after 2330 hours on week nights or 2400 hours on Saturday night or nights preceding announced army holidays.

7 Extending credit to military personnel.

8 Accepting "Military Payment Certificates" in payment for goods or services.

9 Accepting identification cards, identification tags, Geneva Convention cards or similar documents as a collateral for goods or services.

10 Failing to maintain order in the establishment.

Owners of business establishments must meet the foregoing provisions to insure the continued patronage of U.S. Security Forces personnel at their establishments. Those who do not will be promptly placed "Off Limits." Roy E. Linguist, Brigadier General, Commanding ${ }^{9}$

The Military Police were sent to raid known prostitution establishments, mainly to chase the soldiers out rather than to arrest the women. Such raids 
were commonplace, and, though irritating, the brothel owners and the women working there grew to expect this interference. In some instances, however, the Military Police crossed one line too many when the raids trampled on Japanese culture, sometimes quite literally. The following letter, which must have elicited no small amount of laughter at base headquarters as it was delivered, was written by the Provost Marshal of Camp Chickamauga to Beppu City leaders regarding a complaint from local brothel owners.

It has been brought to my attention that Military Policemen under my command have been entering houses of prostitution in search of soldiers without first removing their boots. I regret these actions and have taken immediate action to insure strict compliance with the Japanese custom of removing shoes or covering them with suitable protective covering. I want to assure each house owner that future incidents will not occur again as all Military Policemen have been personally instructed by me on this matter. Charles W. Hill, Captain, MPC Provost Marshal ${ }^{10}$

Basically, the demand was so great, and the local Oita economy so dependent on them, the Pan-Pan girls were allowed to continue their trade, even though it was technically illegal to do so. As the nature of the work changed, life became more complicated and difficult for many of the owners and prostitutes. One local observer recounts that, even though closures due to sanitary conditions continued on and off for years, soldiers kept coming and business was strong. But the businesses were not regulated now, and problems arose. He recounts those days, writing:

The American soldiers didn't know Japanese and didn't know how to count the Japanese yen, so they got cheated by pimps and were brought into Pan-Pan houses instead of promised hotels. House managers, cycle rickshaw workers, and pimps worked together to trick soldiers. However, the money was split between these three and the Pan-Pan girl. So the girls ended up only getting one-fourth of what the soldiers paid. ${ }^{11}$

Because the trade was not regulated and health checks not enforced, STDs continued to infect both prostitutes and clients. Houses offering only oral 
sex became popular among troops worried about catching the disease, but they, like other places, were eventually shut down during the series of antiprostitution crackdowns. It didn't matter much, as houses just relocated and kept up their trade. In some cases they moved from the designated red light district to more mainstream communities to avoid detection. Recalls police officer Toyoji Koya:

Some women rented rooms in a house in Soen. In fact, this was not an uncommon practice. But with people busy coming and going, they'd be discovered and shut down. We kept tabs on these girls, because the houses were illegal. We even kept records on them when they moved houses. The women working in the bars, however, were registered as legal, and we didn't bother them. The Occupation forces were mostly worried about STDs, but there were so many loopholes, the businesses continued, whether legal or illegal. The most severe punishment for the girls was forced hospitalization if they were discovered to carry a disease. ${ }^{12}$

Many brothel owners complained that Americans refused to pay for services while providing an IOU, which might never be paid. But because it was illegal to offer the Americans their services, they could not report the soldiers to military authorities. So they had to take the loss. Some girls grew addicted to alcohol, while others became drug addicts, mostly through the temptations offered by American soldiers who brought drugs to Beppu from outside Japan. Former Beppu policeman Koya, who was assigned to work with the American Military Police, explains why the camp commanders were so concerned to shut down certain establishments. "The drugs, mostly ephedrine, came from the Occupation forces. They sold drugs to get money so they could visit the girls. We wanted to control it, but there were too many soldiers involved, and we couldn't deal with all of them."13

\section{Crazy Mary and Miss Beppu}

The drugs, alcohol, and STDs took its toll on many of the women. One infamous story of a Pan-Pan girl crushed by the dark side of the Occupation is that of Beppu's "Crazy Mary.” 
It was said that "When Mary moves, we will know where the army is moving. When the fleet comes in, Mary appears." She had a dog that performed tricks in front of Beppu station. When soldiers walked by, she'd hold out her hand and say, "Give me money." No one knew if she was in her right mind or not. Sometimes, she walked the red light district of Nagarekawa Street shooting a gun in the air. Other times, she hid in the Akiba shrine from the MPs. It was said that she was married to a soldier from San Francisco, only for half a year, before he was killed in Korea. ${ }^{14}$

Not all the girls working in Beppu despaired of their fate or, like Mary, went crazy. Some of the entrepreneurial ones adjusted to the new legal realities and thrived, at least until the Americans left the city in 1956. One especially popular lady was known as "Miss Beppu." This lady plied her trade between Nagarekawa Street and the Ginzagai, which served as entrance to the center of Beppu. The area was called "Pan-Pan Market." It was a place where pimps and cycle rickshaws stationed themselves, waiting for soldiers to walk by. In most cases, the drivers took the soldiers to their respective employers' house. A few of the girls, however, had picked up business skills by this time, and owned their own entertainment room, even owning their own rickshaws with their own drivers. "Miss Beppu" was one of those. She wore Chanel No. 5 perfume, likely a gift from an admiring soldier, and always carried a folding fan when riding in her rickshaw. She wasted no time on the common soldier, but sent suggestive glances from the rickshaw to white soldiers above the rank of Master Sergeant. She lived in Ukiyoshiji, the main street for the Pan-Pan houses, in a room decorated with lace curtains and beautiful flowers. According to local lore, she was reputed to have a gorgeous bed behind those curtains. Many Beppu citizens were fascinated by her brashness and a bit envious of her success. Her performance in the street and behind her curtain was put on hold, it was said, only when her younger brother came home from university. On those days, she wore no makeup and changed into a sweet sister. ${ }^{15}$

This was also a time when many Beppu housewives operated as part-time Pan-Pan girls. Wives would leave home as if going to the grocery store for the family, and take a side route to one of the houses. Sometimes they would bring the soldiers to their home, sending their children outside for a while. When asked by a friend why she did this, one woman explained 
simply that her husband made too little money, and this was an easy way to support her family. ${ }^{16}$

Despite the give and take between the Pan-Pan girls and the American military establishment over the years between 1945 and 1956 and the problems brought from black market and drug problems, overall the presence of American military in Beppu and surrounding towns helped raise the standard of living far more than if they had been absent. From the brothels in the red light district to the fruit stands on main street, to the well-paying jobs available in carpentry and food preparation inside Camp Chickamauga, opportunities grew more plentiful and extra incomes helped people rebuild their lives.

\section{The Korean War and Exit from Beppu}

The Korean War was a particularly booming period, as soldiers flooded into the town with money to spare, and the American government made sure its soldiers lived comfortably as they either prepared for battle only hundreds of miles away in Korea, or came back for $R \& R$, or rest and recreation. The only down side to this, as remembered by many from that period, was the sadness with which people in Beppu learned of the many deaths of young men they had only recently come to know, if only casually.

The command structure of Camp Chickamauga was transformed during the Korean War, and this change brought new prestige to Beppu when it played host to higher levels of commanding generals. It also presaged the transition from the wars of the Pacific and Korea to one in Southeast Asia. General Mark Clark, known widely for his role in the European theater during World War II, was one of those officers who visited Beppu to inspect his troops as commander of the Far East Command in the United Nations forces. Another was General William S. Westmoreland, destined only a decade later to become the commanding general of American forces in Vietnam. Westmoreland and his family resided for a period of time in Beppu, while he shuttled back and forth between Korea and Japan as Commanding General of the $187^{\text {th }}$ Airborne Regimental Combat Team, which was now stationed in Beppu. Westmoreland was keen to maintain excellent relations with the local Japanese officials and on many occasions visited with them socially and professionally to enhance those ties. He often wrote letters of thanks for their kindness to him and his men. Many letters merely reflect diplomatic 
protocol and address mundane topics. But Westmoreland recognized the value of such casual diplomacy in maintaining support for America's active role in the region. One reason for this was the influence of the communists and socialists active in Oita and throughout Japan at the time, a serious concern given the war with North Korean and the presence of Chinese communist troops only a few hundred miles away. No event or meeting was too small to recognize. This is an example of such a letter, sent to the Beppu liaison representative between the military and the local government three months before the end of the Korean War.

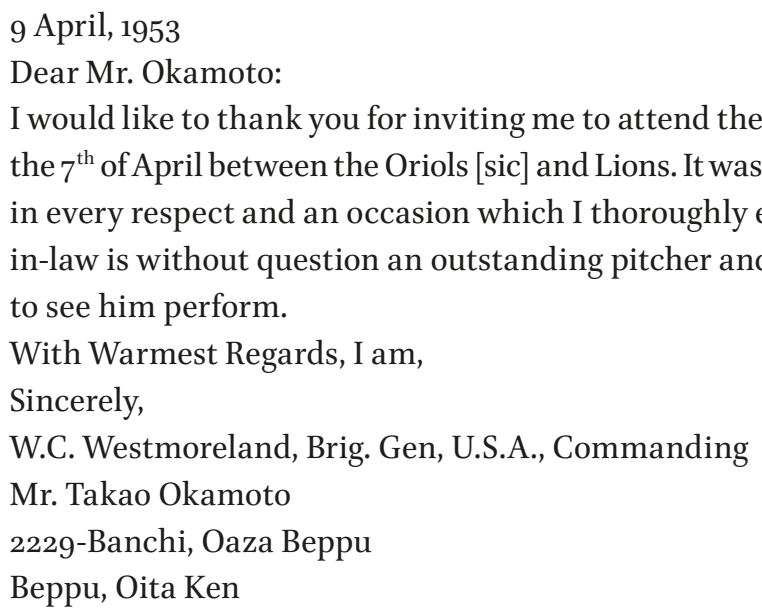

In July 1953, the armistice was signed that ended the fighting in Korea. Because the truce was shaky and failed to eliminate concerns about further warfare with China, American forces remained in Japan, and still remain to this day. U.S. troops stayed in Beppu until their camp closed for good in 1956. 


\section{Conclusion}

Completing this book 70 years after the end of the war, and the $75^{\text {th }}$ anniversary of the attack on Pearl Harbor, the authors sense the timeliness and importance of the stories shared here. It also allows for reflection on the aftermath of the war and how Japan today has come to grips with this legacy.

The people of Oita Prefecture, both as citizens on the home front and soldiers on many fronts, had given unquestioned loyalty to their emperor and military leaders for most of the first half of the $20^{\text {th }}$ century. Many died and those who survived lost relatives and friends on faraway battlefields and at home as a result of bombing and strafing from the feared American airplanes. Children quit school to produce munitions and repair fighter planes. Teenagers flew off on kamikaze missions, leaving behind grieving parents. And young women served as nurses and midwives, tending patients as hospitals burned and babies delivered in earthen shelters.

The people believed what the media told them, followed their leaders, no matter how confused the orders might be, and worshiped their emperor with an unswerving blind faith. Today, however, many express dismay at how completely they were misled during the war. They believed they were winning until the end and swallowed whole government propaganda about helping raise up their Asian neighbors. How does a government trick a whole nation? To understand this, we draw on parallels from China, for this reality bears striking similarity with Ran Ying's experience as a student during China's Cultural Revolution. It is easy to criticize this unreserved "group think" if one comes from a society where individual rights and freedom of expression is taken for granted. That, however, does not define life in a totalitarian society where not only are critical comments never uttered, they are in fact hardly thought of in the first place. In both instances, the few lines of communication were controlled completely by the government. Like Ran Ying reading only government-approved newspapers, revolutionary novels, and short stories, the people of Japan read only government-approved articles describing military "victories" and stories of heroic martyrs and inferior enemies. It was only after the war that any clarity and truth telling appeared.

And what of today?

At all levels of government, there exists an almost total absence of any penetrating analysis or acknowledgment of those years. In fact, most 
political leaders, even most educators, prefer to avoid the discussion altogether. Unlike Germany, which accepted and acknowledged responsibility for its role in taking Europe to war, Japan finds it just too embarrassing, too difficult, and too painful to acknowledge the atrocities it inflicted around the Asia Pacific region.

To underscore this erasure of history, Oita City recently published the prefecture's official historical timeline, beginning with the Stone Age and updated into the $21^{\text {st }}$ century. Curiously, it omits any mention of events between 1934 and $1945 .{ }^{1}$ An uninformed reader would assume it was a time of no historical importance and consequences, but of course the silence screams out an insecurity and self-deceit masking a painful, irreconcilable past. In today's Japan the CEOs of major corporations and politicians caught in a web of corruption or prideful blunders will go on television, bow deeply and apologize to the people of Japan hurt by their actions. However, a Japanese prime minister appears incapable of visiting those countries colonized and brutalized, acknowledge his country's history and carry out the same traditional protocol to ask forgiveness of non-Japanese. It seems Japan cannot learn from Germany that this is the way to move forward.

This lack of critical leadership articulating a truthful and painstaking account of its role in the war has created a vacuum in time and consciousness. But vacuums never go unfilled, and enhanced nationalist initiatives strive to fill that vacuum by glossing over the horrors of the war and reinterpreting Japan's pacifist constitution to allow greater military might, thus isolating Japan further from its Asian neighbors and marginalizing the voices crying for an honest appraisal.

At a personal level, the war remains a conflicted story for those who lived through it. This tension plays out with those who abhor the actions of their country, yet continue to wax nostalgic for the romance of the era. For example, at the beginning of one interview, upon hearing that the authors were from Hawaii, the interviewee apologized for the "unfair" attack on our home state. Then, when learning Ran Ying had grown up in China, he apologized for the horror her countrymen endured during the invasion of her homeland; however, it is the same gentleman who insists that his home town of Saiki get full credit for its role in preparing for the Pearl Harbor attack. Another interviewee who had worked in the military factory during the war as a student and saw his friends incinerated by American bombs swears the war was a terrible mistake; but a model of the Mitsubishi Zero, html. 
just like the one he used to repair as a child laborer, stands proudly in his office.

The romance of the war is also marketed to children today in local stores, as witnessed by the authors when visiting a hobby store displaying a row of Japan's Mitsubishi Zero and the battleships Musashi and Yamato model kits. Pride in the iconic symbols of that period of course never fully faded, and, indeed, appears to be growing stronger with the encouragement of a government pushing away from an official pacifist stance to a more aggressive military posture.

The authors have witnessed the rising tide of nationalism from our home in Beppu when these right-wing organizations drive their black flagdecorated buses and vans through the streets blaring hateful comments aimed at Chinese and Koreans. Although dismissed by most Japanese as fringe elements of society no better than yakuza, or organized crime, their presence nonetheless intimidates as they shout down opponents, shut down movie theaters, and attack journalists they consider too openly critical of the dark side of Japanese history.

One can only hope that the people of Japan continue to listen to the voices of those like 86-year-old atomic bomb victim Sumiteru Taniguchi, who spoke at the August 9, 2015 commemoration of the Nagasaki bombing. After describing the horror and suffering he and others experienced, Taniguchi closed his comments in dramatic fashion with a warning to Prime Minister Shinzo Abe that the government's “meddling” with Japan's pacifist constitution went against the wishes of all the survivors and would tragically lead once again to war.

Finally, we close with a return to America's Occupation headquarters in Beppu. The land that held Camp Chickamauga is now known as Beppu Park, a beautiful testament to turning swords into plowshares. Each spring cherry blossoms cover the park and in the fall Japanese maple trees turn the grounds into glowing red and yellow. Children play ball and chase each other, while their parents and grandparents picnic and read under the trees beside small streams. Camp Chickamauga now exists only in the foggy memory of a few, with a simple rock placed at the top of the park marking its military past.

This is the place, both literally and figuratively, where the story of this book begins and ends. Initially we planned to tell the story of the American Occupation, only to be drawn to those ageing men and women from Oita Prefecture willing to share with us their memories of the war and Japan's defeat. No doubt, and perhaps ironically, some of them still spend hours each year under the trees of Beppu Park sharing food, drink 
and memories with their friends and families. We end with Mr. Yutani, the first person interviewed for this book who as a child visited the park to "attack" the likenesses of Roosevelt and Churchill. "I only feel relief that we lost the war," he laments. "Otherwise, Japan would be just like North Korea today." 


\section{Chronology of Japanese Historical Events, 1905-1957}

The following chronology records major historical events that led to and occurred during the time ofJapan's war in China and the Pacific, followed by the American Occupation after the war. Integrated in the timeline are important local and regional events that impacted the people of Oita Prefecture during this period. Ofspecial note is the activity of the Oita $47^{\text {th }}$ Regiment, the locally recruited army unit representing the people of Oita Prefecture throughout the waryears. The years shown in parenthesis indicate the traditional Japanese calendar as calculated from the beginning of each emperor's reign until his death.

Date Events

1905 (明治 38 年)

August 9-September 5: Treaty of Portsmouth negotiated and signed in U.S. state of New Hampshire with President Theodore Roosevelt as mediator, acknowledging Japan's defeat of Russia in the Russo-Japanese War and granting Japan authority over parts of northeast China and Korea.Japan is emboldened as a new world power.

1926 (昭和元年)

December 26: Hirohito assumes throne as emperor following the death of his father.

1928 (昭和 3 年)

November 15: Hirohito declared a deity, instituting the cult of emperor worship.

1931 (昭和6年)

September 18: Manchurian Incident (also known as Mukden Incident) leads to Japanese military and civil control over northeast China.

1932 (昭和 7 年)

December 15: Oita $47^{\text {th }}$ Regiment ships out to China.

December 21: Oita $47^{\text {th }}$ Regiment arrives in Zunhua, China, via Pusan, Shenyang (Mukden), and Changchun (Hsinking). 
1933 (昭和 8 年)

October 2: Oita $47^{\text {th }}$ Regiment completes China deployment and returns to Oita.

1934 (昭和 9 年)

February 15: Naval base established in Saiki City, southern coastal city in

Oita Prefecture.

1936

November 25, Anti-Comintern Pact signed between Nazi Germany and Japan. Italy joined the Pact in November, 1937

1937 (昭和 12 年)

July 7: Marco Polo Bridge Incident; Japanese and Chinese troops engage in battle outside Beijing. In response, Japan sends more troops to China and full-scale war ensues.

July 27: Oita $47^{\text {th }}$ Regiment ships out to China, arriving in Zhujiawu, via Pusan, Shenyang, and Beijing.

December 10: Oita $47^{\text {th }}$ Regiment on front lines in Battle of Nanjing.

1938 (昭和 13 年)

March 24: Oita $47^{\text {th }}$ Regiment arrives in Wuhu, home of coauthor Ran Ying Porter's family, as occupying force.

1939 (昭和 14 年)

October 1: Naval air base opens in Usa, a northern coastal city in Oita Prefecture.

1940 (昭和 15 年)

September 27: Tripartite Pact signed in Berlin between Germany, Italy, and Japan.

1941 (昭和 16 年)

August: Admiral Isoroku Yamamoto establishes training center for attack on Pearl Harbor in Saiki Bay, in Oita Prefecture.

September 5: Oita $47^{\text {th }}$ Regiment arrives in Gaoxiong, Taiwan, via Fuzhou, China.

October 17: General Hideki Tojo, minister of the army and a strong advocate for war, takes over as prime minister and forms new cabinet to advise the emperor. 
November 1: Admiral Yamamoto moves air attack training for Pearl Harbor attack from the southern city of Kagoshima to Saiki Bay.

November 19: Japanese fleet sails out of Saiki Bay, heading to the northern Japanese islands in the Kuriles, where attack forces rendezvous and proceed to Pearl Harbor.

December 7: Japanese Imperial Navy attacks Pearl Harbor (December 8 in Japan).

December 9: The emperor's Imperial Rescript, a defense of Japan's attack of Pearl Harbor and other locations in Asia, appears in newspapers across the country.

December 10: Japanese Navy sinks British battleships Prince of Wales and Repulse off coast of Malaysia.

December 25: Hong Kong surrenders to Japanese forces.

1942 (昭和 17 年)

January 2: Oita $47^{\text {th }}$ Regiment deployed to Philippines.

February 15: Singapore falls to Japan; celebrations held all over Japan.

March 8: Oita $47^{\text {th }}$ Regiment arrives in Surabaya on island of Java.

April 18: First air attacks on Tokyo, Yokohama, and Nagoya, known as the

Doolittle Raid, shock government and people of Japan.

June 5-7: Battle of Midway inflicts major defeat on Japanese Navy.

September 5: Oita $47^{\text {th }}$ Regiment arrives on island of Timor.

1943 (昭和 18 年)

April 18: Admiral Isoroku Yamamoto killed when his plane is shot down over the Pacific.

1944 (昭和 19 年)

June 15-July 9: Battle of Saipan in Mariana Islands, bringing major defeat of Japanese Army. U.S. forces now have a land base from which to attack Japan with B-29 bombers.

1945 (昭和 20 年)

January 1: American B-29s observed flying over Oita Prefecture for the first time as they head north for bombing targets in Honshu.

March 18: Americans attack targets on Kyushu with Grumman F6F Hellcat fighter planes and Curtiss SB2C Helldiver bombers, targeting several Oita locations for the first time and leading to many civilian casualties.

April 1: Battle of Okinawa begins. 
April 6-May 4: Kamikaze airmen from naval air base in Usa, Oita Prefecture, launch multiple missions against American ships around Okinawa.

April 21: American B-29s and Grumman Hellcats bomb and strafe numerous locations in Oita Prefecture, leading to many civilian deaths.

May 5: American B-29 brought down over village of Takeda in Oita Prefecture. Surviving crewmen are taken to Tokyo and Fukuoka, where all but one are tortured and executed.

June 23: Battle of Okinawa ends.

August 2: Admiral Matome Ugaki, recently charged by Tokyo to prepare

Kyushu for expected imminent invasion, moves his headquarters from Kagoshima on the southern tip of Kyushu to the naval base in Oita City. August 6: Atomic bomb dropped on Hiroshima.

August 9: Atomic bomb dropped on Nagasaki.

August 11: American military ceases bombing of Oita Prefecture.

August 15: Emperor declares Japan will cease fighting and agree to Allied terms.

August 30: Oita $47^{\text {th }}$ Regiment burns its battle flag as it surrenders to Australian forces in Indonesia.

September 2: Japanese representatives Mamoru Shigemitsu, representing the Foreign Ministry, and General Yoshijiro Umezu, representing the military, sign the Instrument of Surrender aboard the USS Missouri in Tokyo Bay. Both men are from Oita Prefecture.

October 13: Advance team of seventeen American Occupation soldiers arrives in Oita Prefecture from the recently landed $28^{\text {th }}$ Marine Regiment.

1946 (昭和 21 年)

December 15: American Occupation forces establish permanent regional headquarters in resort city of Beppu, Oita Prefecture.

1952 (昭和 27 年)

April 28: American Occupation ends, while American forces remain in Beppu during Korean War.

1957 (昭和 32 年)

March 25: American forces close military base in Beppu. 


\section{List of Interviewees}

Eto, Nobuko (江藤信子), Tsukumi, Oita Prefecture, Japan, August 16, 2012 Goto, Toyoki (後藤豊喜), Oita City, Oita Prefecture, Japan, June 8, 2012 Hamasaki, Misayo (濱崎美佐代), Saiki, Oita Prefecture, Japan, June 9, 2012 Hashimoto, Ichiro (橋本一郎), Oita City, Oita Prefecture, Japan, April 21, 2012

Hirano, Mamoru (平野 守), Usa, Oita Prefecture, Japan, February 25, 2013 Hirata, Soei (平田崇英), Usa, Oita Prefecture, Japan, March 30, 2012 Ikenaga, Yoshito (池永義人), Oita City, Oita Prefecture, Japan, June 8, 2012 Kajiwara, Takeyoshi (梶原武淑), Beppu, Oita Prefecture, Japan, March 24, 2012

Kanda, Minoru (神田 稔), Saiki, Oita Prefecture, Japan, June 9, 2012

Kawamura, Nobuo (河村信雄), Beppu, Oita Prefecture, Japan, June 8, 2012 Kawano, Kiichi (川野喜一), Oita City, Oita Prefecture, Japan, May 25, 2012 Kodama, Naomasa (児玉尚正), Usuki, Oita Prefecture, Japan, June 12, 2013 Kogo, Seiichi (古後精一), Oita City, Oita Prefecture, Japan, May 25, 2012 Ma Jifeng (马继凤), Beijing, China, February 1, 2012

Ma Jisen (马继森), Beijing, China, March 1, 2013

Make, Shukichi (牧 修七), Oita City, Oita Prefecture, Japan, February 22, 2013

Matsumoto, Isematsu (松本伊势松), Ooga, Oita Prefecture, Japan, December 28, 2012

Matsumoto, Yukie (松本幸恵), Ooga, Oita Prefecture, Japan, December 28, 2012, and February 25, 2013

Murayama, Tomiichi (村山富市), Oita City, Oita Prefecture, Japan, July 20, 2012

Nakano, Hidekatsu (中野秀勝), Oita City, Oita Prefecture, Japan, May 25, 2012

Nakano, Jiro (中野次郎), Beppu, Oita Prefecture, Japan, May 23, 2013

Nanri, Shunsaku (南里俊策), Beppu, Oita Prefecture, Japan, November 14,2013

Ninomiya, Yoshio (二宮吉男), Oita City, Oita Prefecture, Japan, April 21, 2012 Ono, Eiji (小野英治), Saiki, Oita Prefecture, Japan, June 9, 2012

Ono, Masako (大野政子), Beppu, Oita Prefecture, Japan, April 1, 2012

Ono, Tadashi, 大野忠Beppu, Oita Prefecture, Japan, May 1, 2012

Ono, Tokie (大野卜キエ), Beppu, Oita Prefecture, Japan, March 31, 2012

Ono, Yasuo (大野靖男), Beppu, Oita Prefecture, Japan, April 1, 2012

Sonoda, Hideo (園田英雄), Oita City, Oita Prefecture, Japan, May 3, 2012 
Takahashi, Nobuko (高橋伸子), Beppu, Oita Prefecture, Japan, May 9, 2012 Takamatsu, Umon (高松右門), Beppu, Oita Prefecture, Japan, May 9, 2012 Takamoto, Hiroko (高元紘子), Beppu, Oita Prefecture, Japan, August 3, 2012 Takaya, Toru (高屋 達), Beppu, Oita Prefecture, Japan, May 1, 2012 Takeda, Kou (武田 剛), Saiki, Oita Prefecture, Japan, June 9, 2012 Tanaka, Yasuo (田中康生), Oita City, Oita Prefecture, Japan, December 5 , 2013

Tani, Akira 谷彰, Beppu, Oita Prefecture, Japan, May 1, 2012

Tetsuo Tsukuda (佃 哲男), Beppu, Oita Prefecture, Japan, March 20, 2012 Tomonari, Tsuruko (友成鶴子), Beppu, Oita Prefecture, Japan, June 20, 2012 Yanase, Yonosuke (柳瀬陽之助), Beppu, Oita Prefecture, Japan, May 9, 2012 Yano, Masaaki (矢野正明), Kitsuki, Oita Prefecture, Japan, June 30, 2012 Yoshimura, Takafumi (吉村隆文), Usa, Oita Prefecture, Japan, March 30, 2012

Yunokawa, Morimasa (湯野川守正), Tokyo, Japan, June 11, 2012

Yutani, Sadayoshi (湯谷貞義), Beppu, Oita Prefecture, Japan, February 1, 2012 


\section{Bibliography}

\section{Primary Sources}

Carlton, Don “Slim”, Wanna Live Forever? Lincoln, Nebraska: iUniverse, Inc., 2005.

Elementary School Japanese Grade 2 (初等科國語 二), Japanese Ministry of Education, Tokyo: Japan Book Co., Ltd., 1942.

Endo, Akinori (ed.), Memories of Youth During the War, Association of Reminiscences: Record of Student Mobilization by Secondary School Students in Oita Prefecture, Oita City, Oita Prefecture, 2005.

Japan Times and Advertiser, Tokyo, 1940-1942.

The Occupation ofJapan, U.S. Planning Documents, 1942-1945. Military Planning for Defeat and Occupation ofJapan, Joint War Plans Committee, Washington D.C., 1945.

Oita Godo Press (大分合同新聞), Oita City, Japan, 1942-1945.

Oita News (大分新聞), Oita City, Japan, 1941.

Ugaki, Matome, Fading Victory: The Diary of Admiral Matome Ugaki, 1941-1945, Pittsburgh: University of Pittsburgh Press, 1991.

Yahara, Colonel Hiromichi, The Battle for Okinawa, New York: John Wiley and Sons, Inc., 1995.

\section{Secondary Sources}

Agawa, Hiroyuki, The Reluctant Admiral: Yamamoto and the Imperial Navy, Tokyo: Kodansha International Ltd., 2008.

Bix, Herbert P., Hirohito and the Making of Modern Japan, New York: Harper Perennial, 2001. Bradley, F.J., No Strategic Targets Left, Paducah, Kentucky: Turner Publishing Company, 1999. Caprio, Mark E. and Yoneyuki Sugiata, Democracy in Occupied Japan, The U.S. Occupation and Japanese Politics and Society, New York: Routledge, 2007.

Charlton, Thomas L., Lois E. Myers, and Rebecca Sharpless, eds. Handbook of Oral History, Walnut Creek, California: Alta Mira Press, 2006.

Cook, Haruko Taya and Theodore F. Cook, Japan at War: An Oral History, New York, The New Press, 1992.

Davis, Roger and Osamu Ikeno (eds.), The Japanese Mind, Tokyo: Tuttle Publishing, 2002.

From Headquarters Camp Chickamauga, APO 32, Policy For Placing Business Establishments “Off-Limits", Beppu City Library Archives, Japan, 1954.

Fujisawa, Mitsumaro (ed.), The World of Usa Air Force V (宇佐航空隊の世界V), Usa, Japan: Toyonokuni Usa Academy, 2012.

Gamble, Adam and Takesato Watanabe, A Public Betrayed, An Inside Look at Japanese Media Atrocities and Their Warnings to the West, Washington DC: Regnery Publishing, Inc., 2004.

Hiramatsu, Takashi, Battle History of Our Hometown Troops (鄉土部隊奮戰史), Oita: Oita Godo Press, 1983.

Hoashi, Itsuo, Asia and the Pacific War and Air Raids on Oita (アジア・太平洋戦争と大分の空襲), (Author self published, 2008: 1-Chome 3-11, Soda Kita-Machi, Oita City, Oita Prefecture, Japan. Hotta, Eri, Japan, 1941, New York: Alfred A. Knopf, 2013.

Hoyt, Edwin P., The Last Kamikaze: The Story of Admiral Matome Ugaki, Westport, Connecticut: Praeger, 1993 . 
—.Inferno, the Firebombing of Japan, March 9-August 15, 1945, New York: Madison Books, 2000. Matsusaka, Yoshihashi, The Making of Japanese Manchuria, 1904-1932, Cambridge: Harvard University Press, 2001.

Matsuki, Ikuo (ed.), The World of Usa Air Force, Vol. I (宇佐航空隊の世界, I), Usa, Japan: Toyonokuni Usa Academy, 1992.

一. The World of Usa Air Force, Vol. II (宇佐航空隊の世界, II), Usa, Japan: Toyonokuni Usa Academy, 1992.

一. The World of Usa Air Force, Vol. III (宇佐航空隊の世界, III), Usa, Japan: Toyonokuni Usa Academy, 1992.

"New Kyushu Museum Breaks Taboo with POW Vivisection Display," The Japan Times, April 4, 2015.

"The $19^{\text {th }}$ Infantry Regiment, 1861-1949", Camp Chickamauga in-house publication, Beppu, Kyushu, Japan, September 20, 1949.

Okumizu, Yoshishige and Yozo Kudo, Documents of US Army:Records of Air Attack in Oita (大分 空襲の記錄), Beppu, Oita Prefecture, Japan, self-published, Colony Printing, 1999.

Peattie, Mark, Edward J. Drea, Hans van de Ven (eds.), The Battle for China, Essays on the Military History of the Sino-Japanese War of 1937-1945, Redwood City, California: Stanford University Press, 2011.

Pike, Francis, Empires at War, A Short History of Modern Asia Since World War II, London: I.B. Tauris \& Company, Ltd., 2010.

Saga, Tadao, Beppuand the Occupation Forces (別府と占領軍), Beppu, Japan:Editorial Committee for Beppu and the Occupation Forces, 1981.

Slackman, Michael, Target: Pearl Harbor, Honolulu: University of Hawaii Press, 1990.

Sledge, E.B., With the Old Breed, New York: Presidio Press, 1981.

Sloan, Bill, The Ultimate Battle, New York: Simon and Shuster, 2007.

The School Weekly, Junior Edition, Volume 73, No. 1, Tokyo, Monday, April 6, 1942.

Wade, Carole and Carol Tavris, Invitation to Psychology, $4^{\text {th }}$ edition, Upper Saddle River, New Jersey, Pearson Education, Inc. 2008.

War Sites in Oita Prefecture (おおいたの戰爭遺跡), Association for Cultural Heritage, Oita City, Japan 2005 .

Yamada, Yuko (ed.), The World of Usa Air Force, Vol. IV (宇佐航空隊の世界, IV), Usa, Japan: Toyonokuni Usa Academy, 2010.

Yamamoto, Masahiro, Nanking: Anatomy of an Atrocity, Westport, Connecticut: Praeger, 2000.

\section{Web Sources}

The Army Air Forces in World War II: Volume V, http://www.ibiblo.org/hyperwar/. Web. March 26, 2012

Chapin, Captain John C., U.S. Marine Corps Reserve (ret), Breaching the Marianas: The Battle for Saipan, www.ibiblo.org/hyperwar/USMC-C-Saipan. Web. February 1, 2014.

"Diary of a Member of the $73^{\text {rd }}$ Bombardment Wing Fliers, The First Flyers to Undertake Missions over Japan, by 'Caleb', Saipan, Mariana Islands, 1944-1945," http://old-new-orleans.com/ Mission_Diary.html. Web. March 26, 2012.

Easton, Thomas, “A Quiet Honesty Records a World War II Atrocity," Baltimore Sun, May 28, 1995, http://articles.baltimoresun.com/1995.05-28/new/1995148003_1_japan-kyushu-universityfukuo. Web. March 6, 2014. 
Helm, Leslie “Reunion at Japanese Port Marks Pearl Harbor Attack," December 6, 1991, http:// articles.latimes.com/1991-12-o6/news/mn-497_1_pearl-harbor. Web. February 16, 2014.

"History of Oita Prefecture", http://www.pref.oita.jp/1040o/o_book/english/hirstory_of_oita. html. Web. July 9, 2012.

Interrogation Navy 13, Captain Yasuji Watanabe, World War II Database, http://ww2db.com/ doc.php?q=194. Web. February 1, 2014.

"Interrogation of Marvin Watkins, For the War Crimes Office, Judge Advocates General's Department, United States of American", home.comcast.net/ winjerd/Pageo5.htm\#Vivisections. Web. July 8, 2013.

Kill-All Order of August 1, 1944. War Ministry, Tokyo, http://home.comcast.net/ winjerd/Pageo5. htm\#Vivisections. Web. July 8, 2013.

"Letter from Marvin Watkins to Mrs. Dale Plambeck", October 19, 1945, home.comcast. net/ winjerd/Pageo5.htm\#Vivisections. Web. July 8, 2013.

"Nanking," http://wapwon.cc/video/Precious-film-of-soon-after-the-Fall-of-Nanking 36 s/ bpIQ7wQbKaE. 1938. (Japanese war propaganda film).

“The Pacific War Online Encyclopedia”, pwencycl.kg.com/A/n/Anami_Korechika.htm. Web. February 1, 2014.

"Ric Anderson: Diary of War", http://cjonline.com/news/2011-08-13/ric-anderson-diary-war. Web. March 26, 2012.

Smith, Charles R., Securing the Surrender: Marines in the Occupation ofJapan: Kyushu Occupation, www.nps.gov/history/online_books/npswapa/. Web. October 24, 2013.

$39^{\text {th }}$ Bomb Group (VII) Crew 14, $7^{\text {th }}$ Mission, Oita Airfields, http://39th.org/39TH/aerial/6oth/ crew 14a.html. Web. March 26, 2012.

World War II Database, http://ww2db.com/person_bio.php?person_id=362, www.generals.dk/ general/Minami/Jiro/Japan.html. Web. February 1, 2014.

Williams, Carol, “5 Minutes of Hell,” Poetic Reelections of the Battle of Okinawa, http://budman61o.hubpages.com/hub/5-Minutes-of-Hell. Web, December 11, 2013.

Yosano, Akiko, www.poemhunter.com/akiko-yosano/. Web, January 28, 2014. 



\section{Index}

Anami, Korechika 149, 158-59

B-29 92, 104-07, 109, 113, 120, 127, 133-36, 138, 141, $152-54,156,159,164,166,229-30$

Battle of Midway 74-6, 229

Beppu 20, 25, 43, 46, 70, 96-7, 108, 125, 129, 141, $163,175,184$ contributions to war effort in $15,30,56,59$, 66- $7,80,87,91,93,124,141$

daily life in 130-31, 135, 170

location of $15^{-6}$ post war and occupation of $11,15,185,188$, 191-93, 196, 202-03, 205-22, 225, 230

Beppu Park 11, 83, 225

Buckner, Simon 148-50

Camp Chickamauga 11, 207-08, 212-13, 217-18, 221, 225

Censorship 18, 74, 204

Changsha 54

Chiang Kai-shek 47, $5^{8}$

China 19, 47, 183, 194, 200-01, 222 author's family in 10, 12, 53, 223 forced laborers from 90

Japanese military in 17, 21, 29, 33, 39-40, 43, $44-6,48-9,52,55,57-9,61,65,71,142$, $159,179,227-28$

Japanese view of $17,19,26,35^{-6}, 41,56,5^{8}$, $62,65^{-6}, 77,88$

Clark, Mark 221

Curtiss Helldiver 96, 229

Dutch East Indies 73

Grumman Hellcat 96-9, 103(n), 104, 113, 116, 129, $132,156,209,229-30$

Guam 29, 37, 134, 136

Hasegawa, Masanori 44-5, 57

Hiji 15, 20, 43, 86, 93, 99, 125-26, 163, 203

Hiroshima 12, 73, 158, 162, 165-66, 172, 181-82, 230

Hitler, Adolf 41-3

Hong Kong 29, 30(n), 37, 229

Hori, Teikichi 36,85

Imperial Rescript declaring the war 29, 229

Imperial Rescript ending the war 167,180

Imperial Rescript on Education 72

Imperial (Royal) Guard 63-4, 161, 172-73, 198, 203

Indonesia 57, 59, 67-8, 174-75, 202-03, 230

Ishiwara, Kanji 17-8

Iwasaki, Tamio 57
Kagoshima 21-2, 162-64, 170, 196, 202, 229-30

Kaiten 125-26

Kamikaze 19, 24(n), 28, 42, 49, 72, 88-9, 92, 94, 97-8, 100-02, 103(n), 117, 120-25, 126(n), 127, 143-47, 162-63, 171-72, 174, 176-79, 198, 203, 223,230

Kill-all order 135,138

Kitsuki 15, 34-6, 43, 85, 99-100, 108, 123, 159, 178

Konoe, Fumimaro 42-3

Korean War 203, 205, 215-16, 221-22, 230

Kwantung Army 17, 44, 159

Kyushu University Hospital 138-39

League of Nations 17,62

LeMay, Curtis 95, 104, 106

MacArthur, Douglas 193

Manchurian Incident 17, 39, 44, 62(n), 227

Marco Polo Bridge Incident 39, 48(n), 228

Missouri 12, 178, 191, 230

Mussolini, Benito 42-3

Nagasaki 12, 46, 58, 95(n), 158, 162, 165-67, 181, 225,230

Nagato 23

Nakatsu 15, 112, 124, 158, 178

Nanjing, Battle of 12, 46-55, 57, 228

Oita $47^{\text {th }}$ Regiment $44,46-8,51,53,55,57,174$, $198,210,227-29$

Oita-Bungo Channel 181-82

Oita City 9, 18, 28-31, 35, 37, 124

air attacks on 95-7, 99, 103-06, 116, 127, 130, $132-33,135,152,154,156$

contribution to war effort in $28-30,35,37$, $41,45,52,63,72,83,87,91-2,95,100,136$, 162,230

daily life in $41,61,65,83,108,116$

location of $15^{-6,20}$

post-war and occupation of $169,173,176,181$, 185, 191-92, 201, 203, 206, 209, 224

Oita Godo Press 37, 75, 99, 105, 123-24, 141-43, 180, 190, 204

Oita Naval Air Base 92, 97, 134

Oita Prefecture 9, 11, 18, 29, 67, 83, 122, 224-25, 227 air attacks on 92, 133, 156, 229-30 B-29 downing in 136 contribution to war effort in $30,43,63,89$, $93,121,124-25,127,129,149,158-59,162$, $165,178-79,223,228,230$

daily life in 61,75

Oka 94, 145, 171 
Okinawa, Battle of 88, 95, 97-8, 100, 101-03, 105-06, 121-24, 132-33, 139, 144-50, 152, 161, $164,177-78,181,210,229-30$

Ooga Village 62, 86, 125-26, 203

Pan Pan Girls 213-21

Pearl Harbor 12, 17, 19-29, 31-2, 34-7, 39, 58, 72-6, $83,85,159,162,176,179,223-24,228-29$

Philippines 57, 60, 66, 73, 122-23, 229

Prince Akihito 64

Recreation Amusement Association (RAA) 212, 215-16

Russo-Japanese War 32, 43, 56, 71, 227

Saiki

air attacks on $95,97,99,103,127,142,154$, 157,176

contribution to war effort in $17-8,39-40,58$, $92,162,225$

daily life in 61

location of $15^{-6}$

post-war and occupation in $24-7,168$, 196-97, 208, 215

training for Pearl Harbor attack in 19-24, $162,224,228-29$

Saiki Bay 19-20, 22-25, 228-29

Saiki Peace Museum 24, 58

Saipan 39-40, 66-9, 143, 229

Shanghai $34,37,46-7,52-3,55^{-6}, 63,91,159,196$

Shigemitsu, Mamoru 62-3, 158-6o, 178, 191, 230

Singapore $37,61,67,73,229$

Supreme War Leadership Council 158-59

Takeda Town 93, 159

downing of B-29 in 136, 138, 230

location of 16
Thousand stitch belt 40, 49, 59, 139

Timor 6o, 174-75, 229

Tojo, Hideki 65,228

Tokyo 19, 22, 28, 36, 47, 74-5, 80, 95, 135, 137-38, $146-47,158-63,166-67,172-73,178,181,203$, 212, 229-30

Tokyo Bay 178, 230

Toyada, Soemu $15^{8}$

Ugaki, Matome 21-3, 75, 95, 162-63, 167, 176-78, 230

Umezu, Yoshijiro 149, 158-59, 178, 191, 230

U.S. Pacific Fleet 21-2, 24, 27(n), 74-5, 95

Usa 99 air attacks on 95, 97-8, 103, 105-06, 109, 111, $114,127,129$ contribution to war effort in 19, 28, 42, 97-8, $100,112,120,228,230$

daily life in $31,61,88,127$

location of $15^{-16}$

post-war and occupation in 116, 196, 203, 207, 215

Usa Naval Air Base 19, 42, 97-8, 105, 109, 112-14, $215,228,230$

Ushijima, Mitsuru 146, 148, 150-51

Usuki 58, 93, 123, 202

Wakatsuki, Reijiro 17-8

Westmoreland, William S. 221-22

Wuhu, Occupation of $53-7,228$

Yahara, Hiromichi 102, 146, 150-51

Yamamoto, Isoroku 19, 21-25, 36, 74, 162, 177, 228-29

Yamato 21, 225

Yusano, Akiko 32-3 